\title{
BNL-64217
}

\section{DERIVING CLEANUP GUIDELINES FOR RADIONUCLIDES AT BROOKHAVEN NATIONAL LABORATORY}

\author{
A. F. Meinhold, S. C. Morris, B. Dionne, * and P. D. Moskowitz
}

*Radiological Sciences Division

Department of Advanced Technology

January 1997

Prepared for

Office of Environmental Restoration

Brookhaven National Laboratory

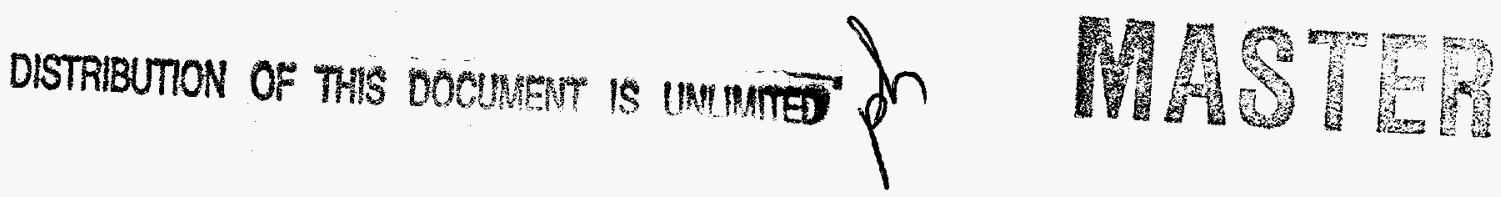

BIOMEDICAL AND ENVIRONMENTAL ASSESSMENT GROUP

ANALYTICAL SCIENCES DIVISION

DEPARTMENT OF APPLIED SCIENCE

BROOKHAVEN NATIONAL LABORATORY

ASSOCIATED UNIVERSITIES, INC.

Under Contract No. DE-AC02-76CH00016 with the

U. S. Department of Energy 


\section{DISGTIADMER:}

Portions of this document may be illegible in electronic inage products: Inages are: produced from thie:best available original document. 


\section{ACKNOWLEDGEMENTS}

This report was prepared for the Office of Environmental Restoration at Brookhaven National Laboratory with guidance from J. Brower and W. Gunther. Support was provided by the United States Department of Energy. 


\section{CONTENTS}

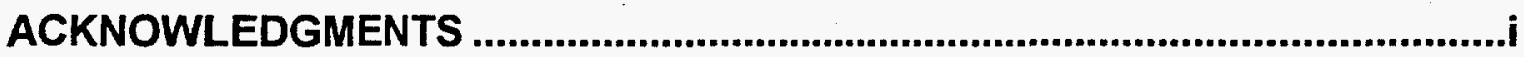

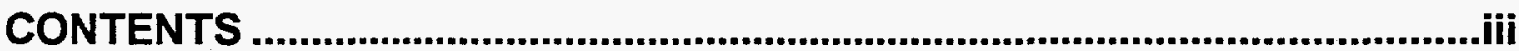

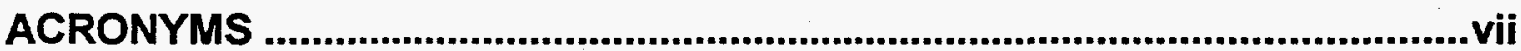

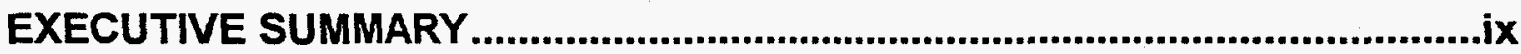

1 INTRODUCTION

2 PROPOSED APPROACH FOR DERIVING RADIONUCLIDE SOIL CLEANUP

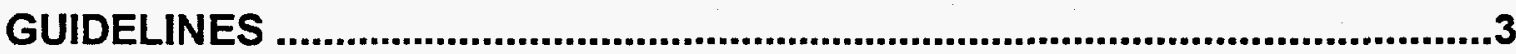

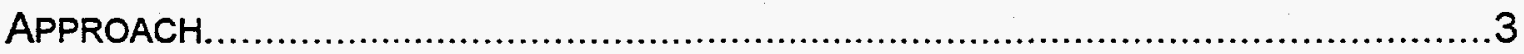

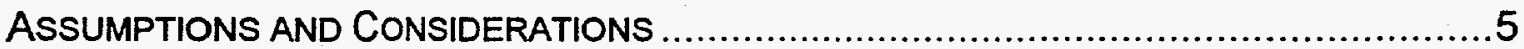

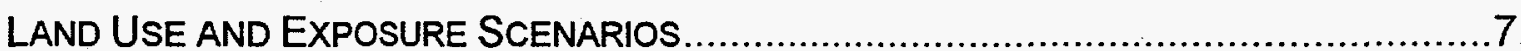

DOSE LIMIT FOR DERIVATION OF BNL CLEANUP GUIDELINES ...............................

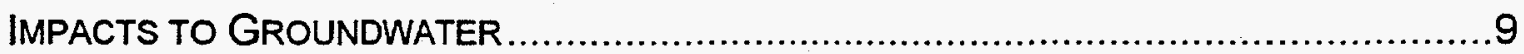

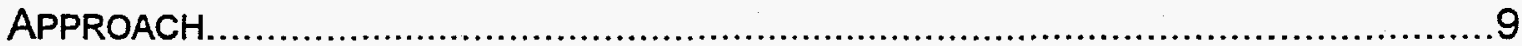

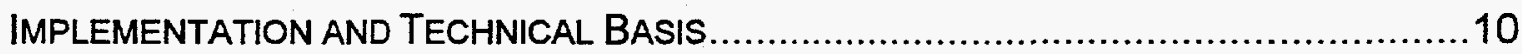

3 CURRENT SITUATION AND FUTURE LAND USE PLAN ..........................11

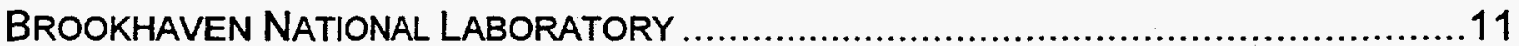

NATURAL ENVIRONMENT AND CONTROLS ON DEVELOPMENT ................................11

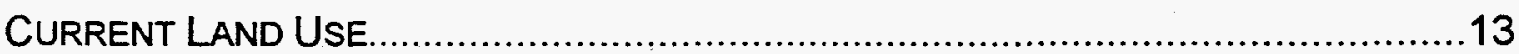

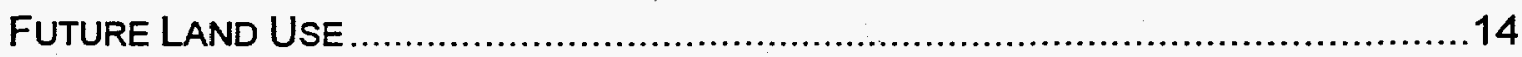

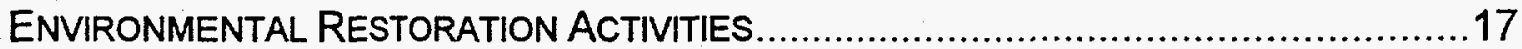

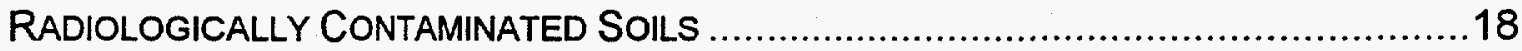

4 ALTERNATIVE SCENARIOS AND EXPOSURE PARAMETERS FOR

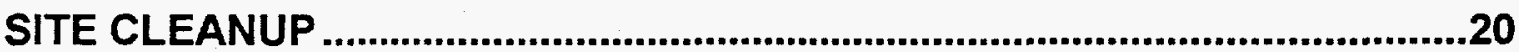

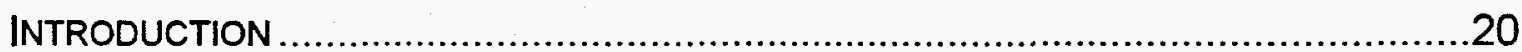

EXAMPLES OF USE OF ALTERNATIVE SCENARIOS AT DOE SITES ...........................22

UNRESTRICTED USE, RESTRICTED USE, AND INSTITUTIONAL CONTROL AT BNL ........23

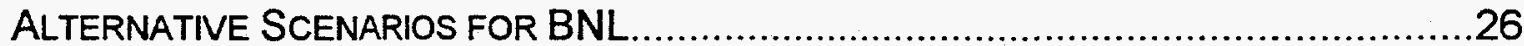

CRITERIA FOR EXPOSURE PARAMETERS FOR ALTERNATIVE SCENARIOS ..................31

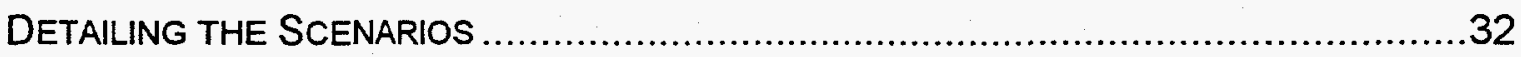

5 DOSE LIMITS FOR DERIVING RESIDUAL RADIONUCLIDE CONCENTRATIONS IN SOIL..............................................................................35

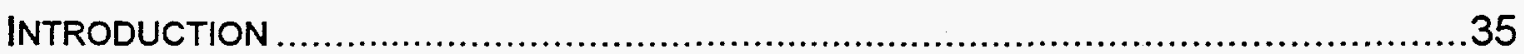

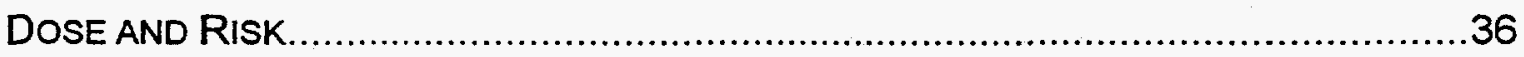

CURRENT REGULATIONS, GUIDANCE AND USDOE ORDERS ................................39

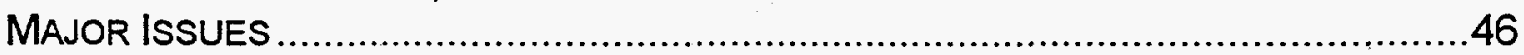


ARARS, DOSE LIMITS AND RISK LEVELS USED BY AT OTHER SUPERFUND SITES WITH

RADIOACTIVELY CONTAMINATED SOIL

RATIONALE FOR USEPA PROPOSED DOSE LIMIT ........................................55

SUMMARY AND RECOMMENDATIONS FOR BNL DOSE LIMIT ................................55

6 IMPACTS TO GROUNDWATER ...................................................................57

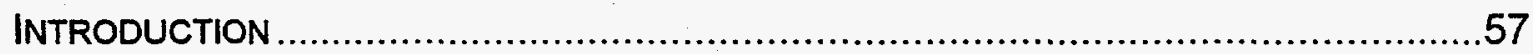

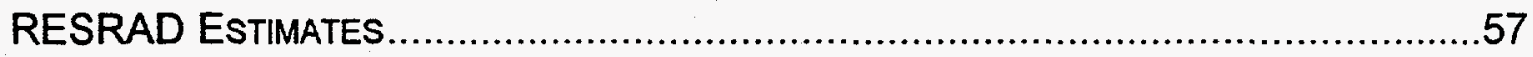

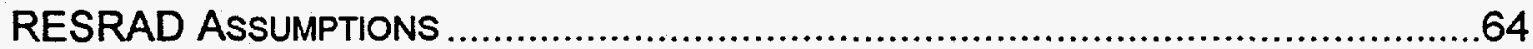

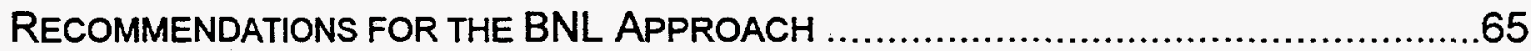

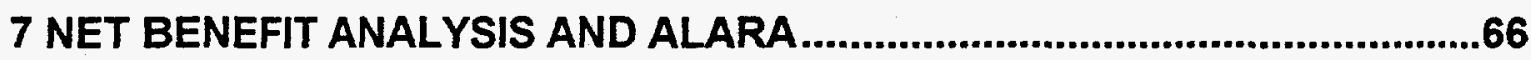

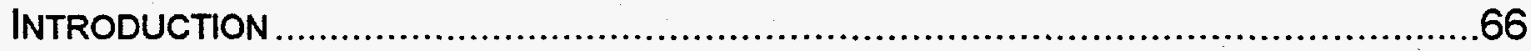

NET BENEFIT ANALYSIS FOR ALTERNATIVES AND REMEDIAL GUIDELINES .................67

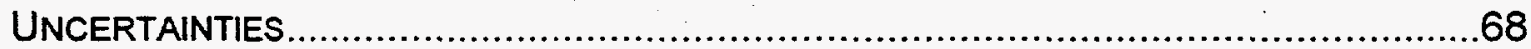

ALARA ANALYSIS FOR SUPERFUND SITES CONTAMINATED WITH RADIOACTIVE

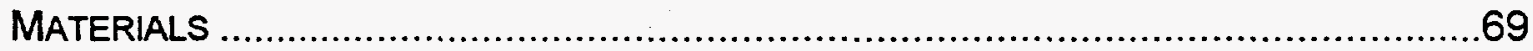

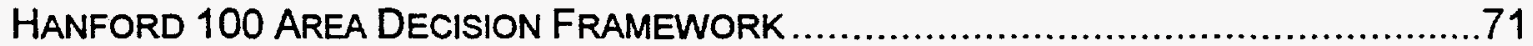

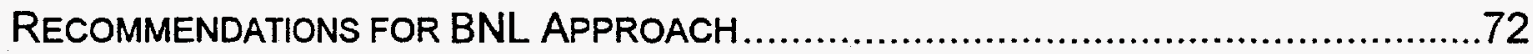

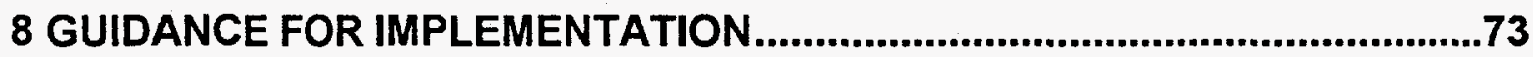

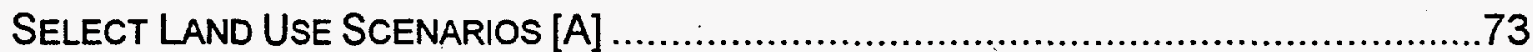

DERIVE PRELIMINARY REMEDIATION CLEANUP GUIDELINES [B] ..........................73

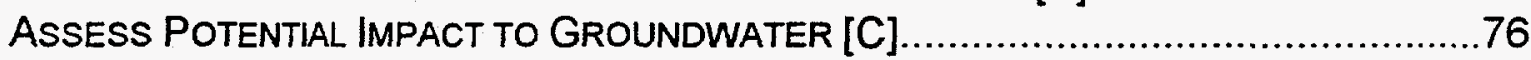

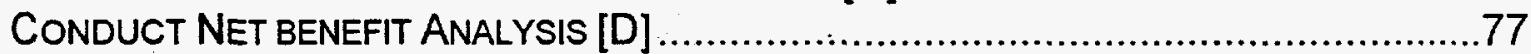

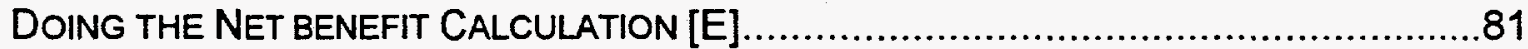

DEVELOP ALTERNATIVE SCENARIOS, DOSE LIMITS AND REMEDIES [F] ...................81

Conduct Net Benefit Analyses to Select Cleanup Alternative [G] ...............8.

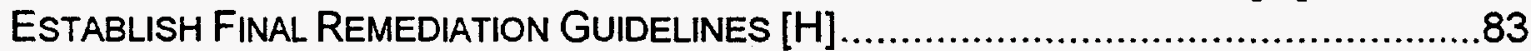

CONDUCT ALARA ASSESSMENT DURING THE DESIGN PHASE [I] ...........................84

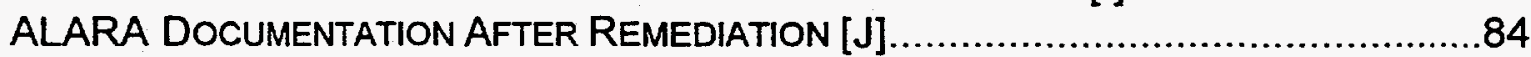

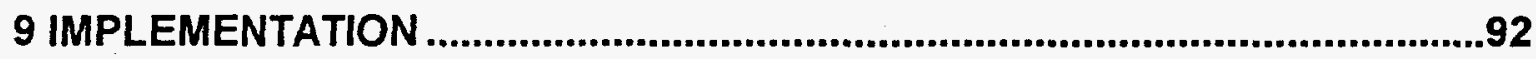

10 REFERENCES

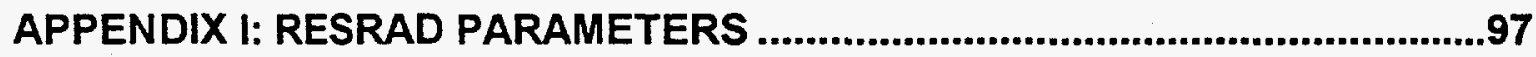

APPENDIX II: DOCUMENTATION OF RME RESRAD SCENARIO

PARAMETERS

APPENDIX III: DOCUMENTATION OF RESRAD PARAMETERS FOR AVERAGE EXPOSURE SCENARIOS.

APPENDIX IV: RADS SOFTWARE FOR CALCULATION OF NET BENEFIT 147 


\section{Figures}

2-1. Proposed approach for deriving cleanup guidelines for radionuclides in soil at $\mathrm{BNL}$

3-1. Pine Barrens core preservation area on the BNL site. ............... 12

3-2. Current land use at BNL (from BNL, 1995) ................................ 15

3-3. Planned future land use (post-closure; from BNL, 1995).............. 16

6-1. Concentration $(\mathrm{pCi} / \mathrm{L})$ and dose $(\mathrm{mrem} / \mathrm{y})$ over time associated with $1 \mathrm{pCi} / \mathrm{g}$ of Sr-90, U-234, U-235, and U-238 in soil at time zero. .... 62

6-2. Concentration $(\mathrm{pCi} / \mathrm{L})$ and dose $(\mathrm{mrem} / \mathrm{y})$ over time associated with $1 \mathrm{pCi} / \mathrm{g}$ of Ra-226 in soil at time zero. 63

7-1. Cumulative soil volumes over a range of cleanup guidelines for Cs-137 at the BNL HWMF

8-1. Proposed approach for deriving cleanup guidelines for radionuclides in soil At BNL. 74

\section{Tables}

2-1. Evaluation criteria

3-1. Area in various land uses at BNL under current and planned post-closure future land use scenarios.

4-1. Future land uses and exposure pathways for BNL.

4-2. Receptors for the RME and average exposure cases for future land use scenarios at BNL

4-3. RESRAD exposure parameters for RME analysis.

5-1. Average individual lifetime risks for a range of potential dose rates using the ICRP and EPA risk factors.

5-2. ICRP and NCRP recommendations for exposures to the public.

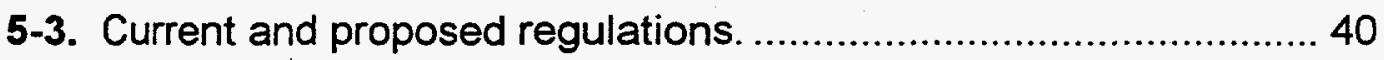

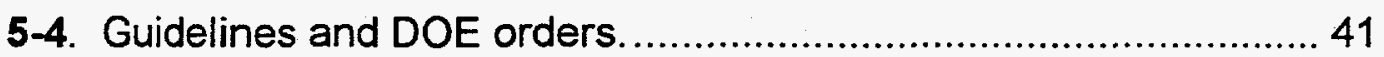

5-5. Background doses in the United States and at BNL ...................46 46

5-6. Radionuclides that may be difficult to detect at $15 \mathrm{mrem} / \mathrm{y}$ above background.

5-7. Incremental cancer deaths averted and costs per death averted.. 49

5-8. Selected exposures and dose limits and associated risks. 50

5-9. ARARS and TBCs for radioactively contaminated sites reviewed by EPA. 
5-10. Dose limits and risk values used to derive radionuclide soil cleanup guidelines at several DOE sites.

6-1. Peak concentrations in groundwater beneath site per unit concentration in soil; concentration conversion factors; USEPA MCLs and associated screening soil concentrations.

6-2. Worst-case concentrations of $\mathrm{Sr}-90, \mathrm{Ra}-226, \mathrm{U}-234, \mathrm{U}-235$ and $\mathrm{U}-238$ per $\mathrm{pCi} / \mathrm{g}$ over 1,000 years. 59

6-3. USEPA and New York State MCLs 64

8-1. Assuming current release of site: generic single-radionuclide preliminary cleanup guidelines based on $15 \mathrm{mrem} / \mathrm{y}$ dose limit for four land use scenarios and $75 \mathrm{mrem} / \mathrm{y}$ for a suburban resident. .. 85

8-2. Assuming release of site in 50 years: generic single-radionuclide preliminary cleanup guidelines based on $15 \mathrm{mrem} / \mathrm{y}$ dose limit for four land use scenarios and $75 \mathrm{mrem} / \mathrm{y}$ for a suburban resident ... 86

8-3. Assuming release of site in 100 years: generic single-radionuclide preliminary cleanup guidelines based on $15 \mathrm{mrem} / \mathrm{y}$ dose limit for four land use scenarios and $75 \mathrm{mrem} / \mathrm{y}$ for a suburban resident. .. 87

8-4. Peak concentrations in groundwater beneath site per unit concentration in soil; concentration conversion factors; USEPA MCLs and associated screening soil concentrations 88

8-5. USEPA and New York State MCLs. 89

8-6. Input parameters for net benefit calculations (EPA, 1995b) 90

8-7. Area planned for future land uses at BNL and assumed population density of number of visitors. 91

8-8. Values for hot spot multiplication factors (from Yu et al., 1993).... 91 


\section{ACRONYMS}

\begin{tabular}{|c|c|}
\hline ALARA & As Low As Reasonably Achievable \\
\hline AGS & Alternating Gradient Synchrotron \\
\hline ANL & Argonne National Laboratory \\
\hline AOC & Area of Concern \\
\hline APM & ALARA Protective Measure \\
\hline ARARS & Applicable or Relevant and Appropriate Regulations \\
\hline AUI & Associated Universities Incorporated \\
\hline BNL & Brookhaven National Laboratory \\
\hline CDM & Camp, Dresser \& McKee \\
\hline \multirow[t]{2}{*}{ CERCLA } & Comprehensive Environmental Response \\
\hline & Compensation and Liability Act \\
\hline CFR & Code of Federal Regulations \\
\hline DOE & United States Department of Energy \\
\hline EPA & United States Environmental Protection Agency \\
\hline FEMP & Fernald Environmental Management Project \\
\hline FR & Federal Register \\
\hline FS & Feasibility Study \\
\hline HWMF & Hazardous Waste Management Facility \\
\hline IAEA & International Atomic Energy Agency \\
\hline IAG & Inter-Agency Agreement \\
\hline ICRP & International Commission on Radiological Protection \\
\hline $\mathrm{MCL}$ & Maximum Contaminant Level \\
\hline MDC & Minimum Detectable Concentration \\
\hline NA & Not Applicable \\
\hline NESHAPS & National Emisśion Standards for Hazardous Air Pollutants \\
\hline NCP & $\begin{array}{l}\text { National Oil and Hazardous Substance Pollution } \\
\text { Contingency Plan }\end{array}$ \\
\hline NCRP & National Council on Radiation Protection and Measurements \\
\hline NRC & United States Nuclear Regulatory Commission \\
\hline NYS & New York State \\
\hline
\end{tabular}


NYSDEC

OER

OU

RA

RADS

RAGS

RBE

RESRAD

RME

ROD

$S A B$

SAIC

SCDHS

SCWA

SI

TAGM

TBC

TLD

UMTRA

UMTRCA

USDOE

USEPA

USGS

USNRC

VOC

WL
New York State Department of Environmental Conservation Office of Environmental Restoration

Operable Unit

Removal Action

Radiological Assessment and Design System

Risk Assessment Guidance for Superfund

Relative Biological Effectiveness

Residual Radioactive Material Guidelines

Reasonably Maximally Exposed Individual

Record of Decision

Science Advisory Board

Science Applications International Corporation

Suffolk County Department of Health Services

Suffolk County Water Authority

Systeme International

Technical Administrative Guidance Memorandum

To Be Considered

Thermoluminescent Dosimeter

Uranium Mill Tailings Remedial Action

Uranium Mill Tailings Radiation Control Act

United States Department of Energy

United States Environmental Protection Agency

United States Geological Survey

United States Nuclear Regulatory Commission

Volatile Organic Carbon

Working Level 


\section{EXECUTIVE SUMMARY}

\section{Introduction}

Past activities at Brookhaven National Laboratory (BNL) resulted in soil and groundwater contamination. As a result, BNL was designated a Superfund site under the Comprehensive Environmental Response Compensation and Liability Act (CERCLA). BNL's Office of Environmental Restoration (OER) is overseeing environmental restoration activities at the Laboratory, carried out under an Interagency Agreement (IAG) with the United States Department of Energy (DOE), the United States Environmental Protection Agency (EPA) and the New York State Department of Environmental Conservation (NYSDEC).

With the exception of radium, there are no regulations or guidelines to establish cleanup guidelines for radionuclides in soils at BNL. BNL must derive radionuclide soil cleanup guidelines for a number of Operable Units (OUs) and Areas of Concern (AOCs). These guidelines are required by DOE under a proposed regulation for radiation protection of public health and the environment (10 CFR Part 834) as well as to satisfy the requirements of CERCLA.

Site cleanups under Superfund must meet identified ARARS (Applicable or Relevant and Appropriate Regulations). When no ARARS are available, guidelines and nonpromulgated regulations are to be considered (TBC), and remedies are selected such that "the excess risk from any medium to an individual exposed over a lifetime generally falls within the range from $10^{-6}$ to $10^{-4 n}$ (preamble to the National Contingency Plan (NCP), Federal Register 8686, March 8, 1990).

Application of the RESRAD (Residual Radioactive Material Guidelines, Yu et al., 1993) computer code constrained by a dose limit of $30 \mathrm{mrem} / \mathrm{y}$ is a standard approach used at DOE sites to derive remedial guidelines for radionuclides in soil. When faced with the absence of ARARS, a number of DOE sites have derived remedial guidelines by limiting risks to potential receptors (recreational users, trespassers, residents) to the range required by Superfund (generally $10^{-6}$ to $10^{-4}$ ) using United States Environmental Protection Agency (USEPA; EPA 1991) methods rather than the RESRAD code.

The objective of this report is to propose a standard approach to deriving risk-based cleanup guidelines for radionuclides in soil at BNL. Implementation of the approach is briefly discussed. ${ }^{1}$

\footnotetext{
${ }^{1}$ The approach suggested here was generally adopted by BNL and DOE in deriving soil cleanup guidelines, but some specific parameters and assumptions were modified in response to regulatory agency and DOE concerns.
} 
Several assumptions form the cornerstone of an approach to deriving cleanup guidelines:

- the dose limit applied to control exposure and risk from residual radioactive material;

- the land use scenarios and exposure parameters used in the analysis of exposure, dose and risk to potential future receptors; and

- the length of institutional control period assumed.

The approach described here also considers the costs and net benefits of remediation to the derived cleanup guidelines, and uses DOE's guidelines for applying the ALARA process to cleanup of the environment.

This report gives recommended elements of the approach for BNL and their technical bases, and the overall approach is summarized. Implementation of the approach is underway, and more detailed documentation of the final guidelines is being prepared.

\section{Brookhaven National Laboratory}

Brookhaven National Laboratory (BNL) is a DOE facility operated by Associated Universities. Inc. BNL is located on Long Island, New York, and consists of $21.3 \mathrm{~km}^{2}(2,130 \mathrm{ha})$. Most of the property is wooded, except for a developed area in the middle of the site of about $6.7 \mathrm{~km}^{2}(670 \mathrm{ha})$, and outlying facilities $\left(2.2 \mathrm{~km}^{2} ; 222 \mathrm{ha}\right)$ including a sewage treatment plant, research agricultural fields, housing and fire breaks. The general location of the buildings, roads and utilities are a legacy of the former Camp Upton.

Seventy-five percent of the site is in open space use. Most of the approximately 350 buildings and other structures are located in the centrally located developed area of the site which is currently designated for commercial/industrial use.

Potable water at the laboratory is drawn from deep wells. The water is monitored to ensure that it meets Federal and State drinking water standards, and is treated before use when necessary.

Approximately 30.25 ha (1.4\%) of the BNL property is contaminated with detectable concentrations of radionuclides in soil above background. These soils are located in several operable units (OUs). Radiologically contaminated soils will all be addressed under one Feasibility Study and final remedial action. Radiologically contaminated soils at BNL can be grouped into three categories: Hazardous Waste Management Facility (HWMF)

The HWMF was the central receiving and storage facility for radioactive materials and waste at BNL for 50 years. Soils in the HWMF contain significant radiological contamination. Cesium-137 is the dominant radionuclide with a maximum reported concentration of $810,000 \mathrm{pCi} / \mathrm{g}$. Strontium-90 is the second most prevalent radionuclide in the HWMF with a maximum soil concentration of 
$1300 \mathrm{pCi} / \mathrm{g}$. Approximately 35,000 cubic yards of soil at the HWMF may require remediation.

\section{Other Radiologically Contaminated Soils}

There are several smaller areas of low-level radiologically contaminated soils scattered around the facility. All of these are dominated by Cs-137 and $\mathrm{Sr}$ 90 , and have smaller concentrations than those found at the HWMF. Maximum Cs-137 concentrations in these soils are less than $600 \mathrm{pCi} / \mathrm{g}$.

\section{Building 650}

Building 650 was a decontamination facility for the removal of radiation from clothing and heavy equipment. The mix of radioactively contaminated soils at Building 650 is different from that of other radiologically contaminated soils at BNL. In addition to elevated Cs-137 and Sr-90, these soils contain Eu-152, Eu154, Eu-155, Ra-226, Am-241, U-234, U-235, U-238, Pu-238, Pu-239, Pu-240, $\mathrm{Na}-22$, and Co-60. Approximate maximum soil concentrations are: Cs-137: 1800 pCi/g; Sr-90: 147 pCi/g, Ra-226: 63 pCi/g, Co-60: 24 pCi/g, Pu-239: 250 pCi/g, Eu-152: $580 \mathrm{pCi} / \mathrm{g}$ and Eu-154: $350 \mathrm{pCi} / \mathrm{g}$.

\section{Dose Limit For Derivation Of BNL Cleanup Guidelines}

Except for radium (5 pCi/g; DOE Order 5400.5) no ARARS or TBCs are available to guide cleanup of radionuclides in soil at BNL. EPA, DOE and USNRC (United States Nuclear Regulatory Commission) are planning to promulgate regulations for residual radioactive material in soil. Relevant proposed regulations and current New York State guidelines include:

- EPA Proposed Radiation Site Cleanup Regulation (40 CFR 196; EPA 1995); meant for release of sites, $15 \mathrm{mrem} / \mathrm{y}$ above background levels that may be met by institutional controls; $75 \mathrm{mrem} / \mathrm{y}$ to rural resident if controls fail. MCLs (maximum contaminant levels) in groundwater must be met if practicable.

- DOE Proposed Regulation (10 CFR 834; Radiation Protection of the Public and the Environment); $100 \mathrm{mrem} / \mathrm{y}$ from all sources except background, medical and occupational exposures. Exposure from a single site should be less than $30 \mathrm{mrem} / \mathrm{yr}$. Limits for radionuclides in soils must be derived using approved models.

- New York State Administrative Guideline (NYSDEC, 1993). The guideline suggests a dose limit of $10 \mathrm{mrem} / \mathrm{y}$ above background, is meant for release of sites, and allows consideration of institutional controls.

Because of the large variation in background exposure across the United States and even within a single site, it will be difficult to document background levels at a specific site. Because of uncertainty in background levels, there can be difficulty in determining compliance with low dose limits. 
Cleanup to low exposure rates from soil is not very cost-effective in terms of the number of deaths averted. In EPA's proposed Radiation Site Cleanup Standard (October 21, 1993; 58 FR 54474), the agency calculated the costs and the deaths averted by remediating soils for all Federally owned sites with radionuclide soil contamination. Very few cancer deaths were averted, and the costs were high even for cleanup from the EPA baseline assumption of 100 $\mathrm{mrem} / \mathrm{y}$ to $75 \mathrm{mrem} / \mathrm{yr}$. Cleanup to $15 \mathrm{mrem} / \mathrm{y}$ was not at all cost effective (incremental costs from 25 to $15 \mathrm{mrem} / \mathrm{y} ; \$ 1000$ million/life saved). An average value currently used by Federal agencies in the U.S. is $\$ 2.1$ million/life saved (Baum, 1994). Dose limits less than $15 \mathrm{mrem} / \mathrm{y}$ resulted in additional deaths from exposure to remediation workers. Ecological risks, liabilities and property values were not considered in this analysis.

In its Proposed Radiation Site Cleanup Regulation, EPA chose $15 \mathrm{mrem} / \mathrm{y}$ because it believed that the $15 \mathrm{mrem}$ standard provides an acceptable level of protection for the public, while standards less stringent would not provide an acceptable level of protection. Acceptable level was defined as consistent with the range of $10^{-6}$ to $10^{-4}$ lifetime risk. The $15 \mathrm{mrem} / \mathrm{y}$ standard corresponds to an estimated lifetime incidence cancer risk of about $3 \times 10^{-4}$ (30 year exposure, fatal cancer risk $2.3 \times 10^{-4}$ ).

The $15 \mathrm{mrem} / \mathrm{y}$ limit is an extremely conservative limit that will be difficult to meet and does not consider the high costs and small benefits associated with meeting a dose limit so close to background. EPA has insisted that BNL derive guidelines based on a $15 \mathrm{mrem} / \mathrm{y}$ dose limit, and New York State requested a 10 mrem/y limit.

In the proposed approach, when feasible, BNL will meet a dose limit of 15 mrem/y assuming the institutional control associated with land uses other than rural residential use, and $75 \mathrm{mrem} / \mathrm{y}$ for suburban residential use assuming failure of these institutional controls. When the $15 \mathrm{mrem} / \mathrm{y}$ guideline is associated with unacceptable potential damage to ecological values, additional risks to the public or workers, or costs, BNL should base the cleanup guidelines on an alternate scenarios/dose limit combination that protects the public to at least $75 \mathrm{mrem} / \mathrm{yr}$. In this situation, alternatives that do not involve soil excavation (e.g. capping, fencing) should be considered.

The BNL assumptions differ from the proposed EPA rule in that the 75 $\mathrm{mrem} / \mathrm{y}$ dose limit associated with a loss of institutional control is assumed for a suburban resident rather than a rural resident because this is the most likely future residential land use near BNL.

Earlier guidelines derived for BNL have treated the $5 \mathrm{pCi} / \mathrm{g}$ limit for radium (DOE Order 5400.5) as a separate limit not included in the overall dose limit for radionuclides in soil (BNL, 1996). This approach suggests including the dose from radium in the overall dose limit as there is no risk-based reason to treat radium separately. However, remediating to a $15 \mathrm{mrem} / \mathrm{y}$ level for radium is not 
cost-effective, and DOE may decide to use the $5 \mathrm{pCi} / \mathrm{g}$ standard for radium at BNL.

\section{Restricted Use And Institutional Control}

The Myth of Unrestricted Use

If clean-up were designed toward release of the BNL site for unrestricted use at some future date, proposed EPA guidance would suggest assuming a resident-farmer land use scenario (EPA, 1995). This is a family spending a substantial portion of time outdoors on the land, in contact with soil, who grow a

substantial percentage of their food on the land, produce meat, poultry and milk, and whose drinking water comes from a private well tapping groundwater beneath the site. Their level of exposure is high in terms of time and pathways.

Even for an unrestricted use, this is not a realistic scenario for the BNL site. Farming is declining on Long Island, not growing. BNL is no longer in the country side; it is being rapidly surrounded by suburban growth with accompanying commercial and industrial development. A reasonable residential scenario would be suburban development, not a family farm. Meetings with stakeholders as part of the development of the future use plan (BNL, 1995) produced no suggestion of agricultural use. Advocates of residential land use proposed either institutional housing or low density residential zoning. It should be noted that low density residential zoning on Long Island does not indicate people who are subsisting on the land.

But even suburban development may not be the most likely future were the site to be released. The BNL site is located in the Long Island Pine Barrens, a valuable natural resource. The core area of the Pine Barrens (comprising approximately $54 \%$ of the BNL site) is protected by the State of New York (Central Pine Barrens Joint Planning and Policy Commission, 1995). Much of the BNL site remains close to its natural state and BNL plans to continue to preserve this status as much as possible while carrying out its DOE mission (BNL, 1995). The BNL Future Land Use Plan reflects the public expectation that the bulk of the site will remain open space.

What will dictate the use of the land when the site is released? At this location, "unrestricted use" does not exist. The area is subject to the State Pine Barrens Plan, the Special Groundwater Protection Plan, the Long Island Comprehensive Wastewater Management Plan and local zoning controls. Wells may not be installed without a permit. Connection to a public water supply is mandatory for most new construction.

Restricted Use and Institutional Control

Restricted use includes actions ranging from retaining Federal control and putting up fences, to deed restrictions (prohibiting certain uses, e.g., agriculture or residential), deed notices (to alert all future owners of the presence of hazardous substances), or prohibiting use of wells. 
The principal radionuclides contaminating soil at the BNL site are Cs-137 (half-life 30 years) and Sr-90 (half-life 28 years). Maintaining institutional control of the site for $50-100$ years would result in substantial natural decay. If a specific soil clean-up level ( $\mathrm{pCi} / \mathrm{g}$ ) were to be applied at a point $50-100$ years in the future, effective current cleanup standards would be 3- to 8- fold higher than if they were effective today. This could substantially reduce the cost of clean-up with no increase in exposure to the public, provided access to contaminated areas is controlled in the intervening period. There are no plans to close BNL. Moreover, DOE could make a commitment to retain control of the site even if laboratory operations were shut down. In terms of meeting criteria for release of the site, this strategy could be decided entirely on a cost basis. While the laboratory remains in operation, there would be incremental costs for monitoring, and costs for maintaining institutional control would be small. Were the laboratory to be closed at some point before site-release criteria were met, there would be additional costs for maintaining security of the site. DOE has already made this decision for OU IV -- preliminary guidelines were derived assuming 50 years of institutional control (BNL, 1996).

\section{If Institutional Control is Lost}

The institutional control that could be lost includes maintenance of land use restrictions and prohibition of private wells after release of the site. These are maintained by local government. The BNL site is relatively small compared to other DOE sites and can easily be monitored. Moreover, state and local government and nongovernmental organizations take a special interest in the site because much of the site is in the core area of the Pine Barrens, a protected environment, and because the site also contains the headwaters of the Peconic River, a designated Scenic River. It is doubtful that institutional controls enforced by local governments would be seriously modified or breached at a site with such environmental and historic significance.

In their draft proposed radionuclide soil cleanup standards (EPA, 1995), EPA proposed a backup in case institutional controls failed. This was $75 \mathrm{mrem} / \mathrm{y}$ in a resident farmer scenario. This would serve to keep public exposure within the $100 \mathrm{mrem} / \mathrm{y}$ limit of DOE Order 5400.5 and the recommendations of the ICRP and NCRP. EPA's proposal, however, was based on data from sites in more rural areas. There is no reasonable possibility that part of the BNL site would become a subsistence farm. The reasonable maximum $75 \mathrm{mrem} / \mathrm{y}$ backup scenario for establishing soil cleanup criteria is the suburban resident land use. The more restrictive of the suburban resident scenario at $75 \mathrm{mrem} / \mathrm{y}$ or the expected land use at $15 \mathrm{mrem} / \mathrm{y}$ should determine the cleanup criteria.

\section{Recommendation for BNL}

Since DOE has no plan to curtail operations at BNL, some future time period for release of the site (e.g. 50 years) is a reasonable assumption. This paper presents generic soil cleanup guidelines assuming three time periods for release: current, 50 years in the future and 100 years in the future. 


\section{Land Use And Exposure Scenarios}

The scenarios characterize the future land-use pattern for the site and surrounding area. The land use that requires the most stringent cleanup criteria is generally considered to be the resident farmer. If the site is cleaned up such that this family is below the maximum tolerable risk level, it is generally considered acceptable for unirestricted use.

Based on current land uses near the BNL site, local controls on development and the BNL Future Land Use Plan (BNL, 1995), a residential farmer scenario is not a reasonable assumption to form the basis of remedial guidelines. The land use types described in the BNL Future Land Use Plan for the post-closure scenario (BNL, 1995) should be used to derive remedial guidelines for cleanups at specific site locations.

Future uses of the site will probably not include exposures to groundwater, because any future uses are expected to have access to public water. Ingestion of drinking water as an exposure pathway for residential, commercial and recreational uses was included at the insistence of the regulatory agencies.

Four scenarios were developed for the BNL site: suburban residential; commercial/industrial; and two open space scenarios, one an undeveloped park and one a developed park. Most of the land on the BNL site is undeveloped. The BNL Future Land Use Plan (BNL, 1995), which was developed with extensive community involvement, determined that future land use at BNL would be primarily open space. Much of the open space on the BNL site is designated as part of the protected core area of the Long Island Pine barrens (Central Pine Barrens Joint Planning and Policy Commission, 1995).

EPA agreed that the likely future land use for the BNL site was open space. EPA insisted, however, that soil remediation guidelines be based on either residential or commercial/industrial land use. Their rationale for this was that, although the public was highly involved in the BNL Future Land Use Planning process, they did not realize at the time that one implication of an open space land use was that soil remediation requirements would be less stringent then residential or commercial. If the actual land use for most of the site is open space, use of residential or commercial/industrial assumptions in developing soil remediation guidelines will introduce a considerable additional margin of safety.

Table E-1 summarizes the exposure pathways assumed for each future land use. 
Table E-1. Future land uses and exposure pathways for BNL.

\begin{tabular}{|l|c|c|c|c|}
\hline Pathway & $\begin{array}{c}\text { Industrial/ } \\
\text { Commercial }\end{array}$ & $\begin{array}{c}\text { Suburban } \\
\text { Residential }\end{array}$ & $\begin{array}{c}\text { Undeveloped } \\
\text { Open Space }\end{array}$ & $\begin{array}{c}\text { Developed } \\
\text { Recreational }\end{array}$ \\
\hline External gamma exposure & Yes & Yes & Yes & Yes \\
\hline Inhalation of dust & Yes & Yes & Yes & Yes \\
\hline Inhalation of radon & Yes & Yes & Yes & Yes \\
\hline Ingestion of plant foods & No & Yes & Yes & No \\
\hline Ingestion of meat & No & No & Yes & No \\
\hline Ingestion of milk & No & No & No & No \\
\hline Ingestion of fish & No & No & No & No \\
\hline Ingestion of soil & Yes & Yes & Yes & Yes \\
\hline Ingestion of water & Yes & Yes & No & Yes \\
\hline
\end{tabular}

\section{Impacts To Groundwater}

The aquifer underlying BNL has been designated a sole source aquifer and assessing potential impacts to groundwater is an important part of the approach for deriving soil cleanup guidelines for BNL. Including the groundwater pathway in RESRAD does not guarantee that MCLs will be met -only that the specified total dose limit will be met for all pathways. RESRAD can be used as a screening tool to assess worst-case potential impacts, but it is too simple and conservative for more accurate analyses. Groundwater models already in use at BNL can be used to estimate potential impacts to groundwater when a RESRAD calculation suggests a potential problem.

The proposed approach is to assess potential groundwater impacts in two steps:

- Use RESRAD to estimate the worst-case future concentration of radionuclides in groundwater beneath the waste site associated with a set of preliminary guidelines. Compare these concentrations to USEPA and NYS Maximum Contaminant Levels (MCLs).

- If MCLs are exceeded in this analysis, perform a more detailed modeling analysis to estimate groundwater concentrations and doses for comparison to MCLs.

If this more accurate analysis suggests that MCLs may be exceeded, BNL should assess the net benefit associated with meeting MCLs, determine if meeting MCLs is practicable, and consider institutional controls that will eliminate the groundwater pathway. This decision should be made as part of the net benefit analysis performed on each set of preliminary guidelines. 


\section{Net Benefit Analysis}

In addressing clean-up of contaminated areas, ICRP indicates that the decision criteria should be "do no harm", that is, the net effect of a clean-up activity should be positive (ICRP, 1991). Cleaning up contaminated areas can have negative impacts, for example:

- Remediation workers can incur radiation exposure and accidental injury.

- Transport of wastes to disposal sites causes traffic deaths and injuries, especially when large amounts of low-level wastes must be transported long distances.

- The natural ecology of an area is often disrupted. This is of particular concern where restricted access to a site has led to preservation of natural habitat for decades in areas where the surrounding area has experienced intensive development.

In its simplest form, net benefit analysis is simply a balancing of the positive and negative aspects of a decision. One difficulty frequently raised about net benefit analysis is that it requires all parts of the decision to be reduced to common (usually monetary) terms so the arithmetic can be done, i.e., the benefits and the costs can each be summed and the difference between them calculated. Translating health risks or ecological values into monetary terms is controversial and reducing decisions to arithmetic is suspect.

Transformation into monetary terms, however, is not necessary in cases where decisions are fairly straightforward. In this case, for example, the following factors could be evaluated by the decision makers:

- suitable future land use

- clean-up levels for residual radioactive material

- public health risk

- worker health risk

- preservation of wildlife habitat

- cost of clean-up

What are the relationships? Increased clean-up leads to decreased public health risk, increased worker health risk, and increased destruction of habitat. Extensive clean-up may yield public health risks of $1 \times 10^{-5}$ life-time cancer, destruction of habitat, extensive worker exposure and very high costs. A life-time risk guideline of $1 \times 10^{-3}$, however, might greatly reduce worker exposure, habitat destruction, and costs. The latter risk level is on the order of average exposures from radon gas. This is a range within which trade-offs might be made. Further flexibility can be achieved by land-use control. Residential use of land may require extensive clean-up to maintain acceptable risk, but using the land as a wildlife preserve can maintain the same low risk because the duration and extent of human exposure is much reduced. 
These trade-offs may be controversial and difficult to agree on, but even when dealing with six parameters with different units and different values attached, as in the example, they are easily understood.

A calculation of the net benefit for each remedial alternative and its associated preliminary cleanup guidelines should be done as part of the Feasibility Study (FS) phase of a CERCLA remedial action to help choose between alternatives. The approach suggested here assesses the net benefit of a remedial alternative, and factors into the decision on the final option the level of protectiveness (i.e. dose limit and land use assumptions) embedded in the remedial guidelines for residual radioactivity in soil.

Methods to estimate costs of alternative remedial actions are well established and are routinely performed as part of the Feasibility Study phase of a CERCLA remedial action. Risk to workers and the general public can be estimated using simple models and assumptions (EPA, 1995). Ecological values can be treated in a qualitative way, based on information presented in the Remedial Investigation Study for a specific AOC/OU and other data collected for the site.

These methods can be used to:

- determine if the $15 \mathrm{mrem} / \mathrm{y}$ dose limit can be met without excessive costs, additional human health risks or destruction of important ecological values; and

- help choose among alternatives when the $15 \mathrm{mrem} / \mathrm{y}$ dose limit is impracticable and alternatives that do not require excavation (or total excavation) are considered.

\section{Approach}

The proposed approach, outlined in Figure E-1, uses the RESRAD model (Yu et al., 1993; Version 5.61) to calculate allowable residual concentrations of specific radionuclides in soil at BNL. Preliminary remediation guidelines are derived using a dose limit for the public of $15 \mathrm{mrem} / \mathrm{y}$ above background together with scenario parameters for the land use planned for after site closure (BNL, 1995) or a $75 \mathrm{mrem} / \mathrm{y}$ dose limit to a suburban resident, whichever is most restrictive. The potential impacts to groundwater associated with the preliminary guidelines are assessed using the simple groundwater model in RESRAD. More sophisticated, site specific models are used when the RESRAD analysis suggests that preliminary guidelines could cause MCLs to be exceeded.

When Cs-137 is the dominant radionuclide, guidelines can be based on the single radionuclide criteria derived for Cs-137. Because Sr-90 usually occurs with $\mathrm{Cs}$ in contaminated soils at BNL, potential groundwater impacts associated with residual $\mathrm{Sr}-90$ concentrations in soil must be assessed. When other radionuclides are present in significant concentrations, the guideline for each radionuclide must be based on the weighted sum of the radionuclides in the mixture as described in Yu et al. (1993). 
Figure E-1. Proposed approach for deriving cleanup guidelines for radionuclides in soils at $B N L$.

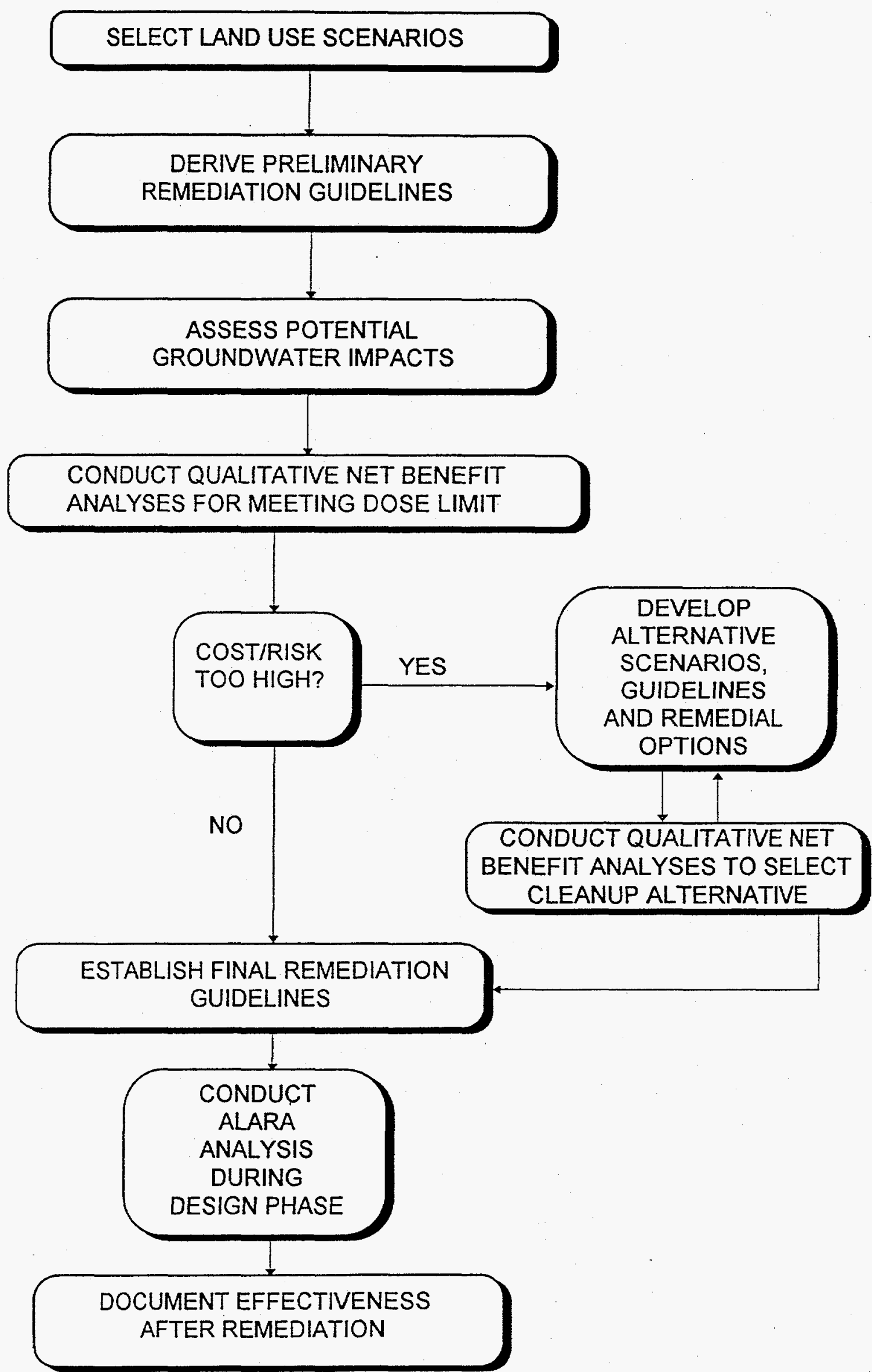


Remedial alternatives that depend on cleanup guidelines are then assessed in terms of the net benefit of cleanup to the preliminary guidelines. Costs of cleanup, potential ecological impacts and additional risks to the public and to remediation workers are compared to the number of cancers averted from performing the cleanup and to the costs associated with long term monitoring and maintenance of institutional controls.

If the costs and risks associated with the preliminary guidelines are reasonable or acceptable for a particular cleanup option that also meets the nine criteria defined by EPA (threshold, balancing and modifying criteria, National Contingency Plan; NCP, 40 CFR 300.430), they are accepted as final (along with the specific remedial option). An ALARA process is used during the design phase to cost-effectively reduce exposures to a reasonable level below the final dose limit. After the cleanup process is complete, a formal process is used to document that a reasonable reduction of radiation exposures was achieved and that they are ALARA.

\section{Generic Guidelines}

Cleanup guidelines will vary across the BNL site because of differences in planned future land uses, different mixtures of radionuclides, differences in the size and nature of the source terms, and site specific geo-hydrological conditions. To reduce the confusion and complications associated with many different cleanup guidelines, generic preliminary cleanup guidelines were derived for BNL. These generic guidelines were derived using conservative boundary conditions and assumptions and represent average site geological and hydrological conditions. They will not always be appropriate because of site specific conditions (e.g. varying depths to groundwater), but do provide a consistent starting place from which more accurate site specific analyses can be performed if needed.

Guidelines were developed assuming current release of the site, release of the site in 50 years, and release of the site in 100 years (Tables E-4, E-5 and $E-6)$. This approach recommends use of the guidelines for release of the site in 50 years, because the DOE currently has no plans to release the site.

The use of alternate land use scenarios and periods of institutional control have large effects on the soil cleanup guidelines. The period of institutional control assumed is especially important radioisotopes with relatively short half-lives (less than 30 years; Cs-137, Co-60, Eu-152, Eu-154, Eu-155, Sr90). 
Table E-4. Assuming current release of site: generic single-radionuclide preliminary cleanup guidelines $(\mathrm{pCi} / \mathrm{g}$ ) based on $15 \mathrm{mrem} / \mathrm{y}$ dose limit for four land use scenarios, and $75 \mathrm{mrem} / \mathrm{y}$ for a suburban resident (guidelines less restrictive than the $75 \mathrm{mrem} / \mathrm{y}$ residential guidelines are shaded).

\begin{tabular}{|c|c|c|c|c|c|}
\hline Radionuclide & $\begin{array}{c}\text { Commercial/ } \\
\text { Industrial }\end{array}$ & $\begin{array}{l}\text { Suburban } \\
\text { Residential }\end{array}$ & $\begin{array}{l}\text { Undeveloped } \\
\text { Open Space }\end{array}$ & $\begin{array}{c}\text { Developed } \\
\text { Recreational }\end{array}$ & $\begin{array}{l}\text { Suburban } \\
\text { Residential } \\
\text { (75 mrem/y) }\end{array}$ \\
\hline Americium-241 & 150 & 36 & 8 & (x) & 180 \\
\hline Cesium-137 & 21 & 7 & s. & (3) & 35 \\
\hline Cobalt-60. & 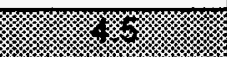 & 1.5 & s & 38 & 7.5 \\
\hline Europium-152 & 10 & 3 & (4) & (x) & 15 \\
\hline Europium-154 & 9 & 3 & (3) & 6 & 15 \\
\hline Europium-155 & 390 & 130 & 2 & 348 & 650 \\
\hline Plutonium-238 & 190 & 44 & 220 & 48 & 220 \\
\hline Plutonium-239 & 170 & 40 & 200 & (1) & 200 \\
\hline Plutonium-240 & 170 & 40 & 200 & (4. & 200 \\
\hline Radium-226* & 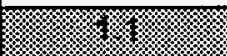 & 0.15 & 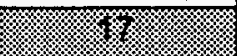 & \% & 0.75 \\
\hline Strontium-90 & 44 & 9 & 6 & (6) & 45 \\
\hline Uranium-234 & 720 & 200 & 730 & 469 & 980 \\
\hline Uranium-235 & 84 & 28 & 46 & 489 & 140 \\
\hline Uranium-238 & 320 & 97 & 3 & 26 & 490 \\
\hline
\end{tabular}

* 5 pCi/g guideline for ${ }^{226} \mathrm{Ra}$ and ${ }^{226} \mathrm{Ra}$ may apply (DOE Order 5400.5 ). 
Table E-5. Assuming release of site in 50 years: generic single-radionuclide preliminary cleanup guidelines ( $\mathrm{pCi} / \mathrm{g}$ ) based on $15 \mathrm{mrem} / \mathrm{y}$ dose limit for four land use scenarios and $75 \mathrm{mrem} / \mathrm{y}$ for a suburban resident (guidelines less restrictive than the $75 \mathrm{mrem} / \mathrm{y}$ residential guidelines are shaded).

\begin{tabular}{|c|c|c|c|c|c|}
\hline Radionuclide & $\begin{array}{l}\text { Commercial } \\
\text { /Industrial }\end{array}$ & \begin{tabular}{|c|} 
Suburban \\
Residential
\end{tabular} & $\begin{array}{l}\text { Undeveloped } \\
\text { Open Space }\end{array}$ & \begin{tabular}{|c|} 
Developed \\
Recreational
\end{tabular} & $\begin{array}{l}\text { Suburban } \\
\text { Residential } \\
\text { (75 mrem/y) }\end{array}$ \\
\hline Americium-241 & 160 & 39 & 4 & 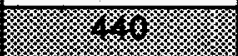 & 195 \\
\hline Cesium-137 & 70 & 23 & 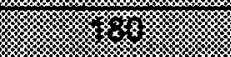 & 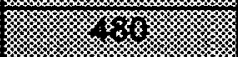 & 115 \\
\hline Cobalt-60 & 3700 & 1300 & (6) & \% & 6300 \\
\hline Europium-152 & 140 & 48 & 夘 & 6 & 240 \\
\hline Europium-154 & 490 & 165 & 866 & 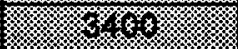 & 830 \\
\hline Europium-155 & $4.3 E 5$ & $1.4 \mathrm{E} 5$ & xy & X & $7.0 \mathrm{E} 5$ \\
\hline Plutonium-238 & 250 & 66 & 330 & (3) & 330 \\
\hline Plutonium-239 & 170 & 40 & 200 & 4 & 200 \\
\hline Plutonium-240 & 170 & 41 & 200 & 的 & 200 \\
\hline Radium-226* & . & 0.15 & (6) & 89 & 0.75 \\
\hline Strontium-90 & th & 75 & 4906 & 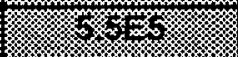 & 380 \\
\hline Uranium-234 & 1200 & 350 & 1300 & 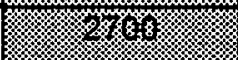 & 1800 \\
\hline Uranium-235 & 130 & 49 & (6) & 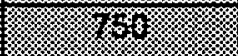 & 250 \\
\hline Uranium-238 & 510 & 175 & (c) & 3) & 880 \\
\hline
\end{tabular}

* $5 \mathrm{pCi} / \mathrm{g}$ guideline for ${ }^{226} \mathrm{Ra}$ and ${ }^{228} \mathrm{Ra}$ may apply (DOE Order 5400.5 ). 
Table E-6. Assuming release of site in 100 years: generic single-radionuclide preliminary cleanup guidelines ( $\mathrm{pCi} / \mathrm{g}$ ) based on $15 \mathrm{mrem} / \mathrm{y}$ dose limit for four land use scenarios and $75 \mathrm{mrem} / \mathrm{y}$ for a suburban resident (guidelines less restrictive than the $75 \mathrm{mrem} / \mathrm{y}$ residential guidelines are shaded).

\begin{tabular}{|c|c|c|c|c|c|}
\hline Radionuclide & $\begin{array}{l}\text { Commercial } \\
\text { Industrial }\end{array}$ & $\begin{array}{l}\text { Suburban } \\
\text { Residential }\end{array}$ & $\begin{array}{l}\text { Undeveloped } \\
\text { Open Space }\end{array}$ & $\begin{array}{c}\text { Developed } \\
\text { Recreational }\end{array}$ & $\begin{array}{l}\text { Suburban } \\
\text { Residential } \\
\text { (75 mrem/y) }\end{array}$ \\
\hline Americium-241 & 180 & 43 & 220 & 致6 & 220 \\
\hline Cesium-137 & 230 & 75 & 6996 & 6. & 380 \\
\hline Cobalt-60 & $3.0 \mathrm{E} 6$ & 1.1E6 & 9 & 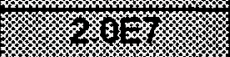 & $6 \mathrm{E} 6$ \\
\hline Europium-152 & 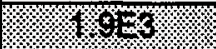 & 652 & 6 & K5 & 3300 \\
\hline Europium-154 & $2.6 \mathrm{E} 4$ & 8640 & W & \% & $4.3 \mathrm{E} 4$ \\
\hline Europium-155 & $4.7 \mathrm{E} 8$ & $1.6 \mathrm{E} 8$ & y y y & x & 8.0E8 \\
\hline Plutonium-238 & 420 & 100 & 500 & 1360 & 500 \\
\hline Plutonium-239 & 170 & 41 & 210 & \% & 210 \\
\hline Plutonium-240 & 180 & 42 & 210 & 45 & 210 \\
\hline Radium-226* & (\%) & 0.16 & 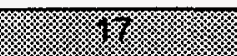 & 3 & 0.8 \\
\hline Strontium-90 & 74 & 40 & 4 & 58 & 200 \\
\hline Uranium-234 & 1800 & 600 & 34 & 48 & 3000 \\
\hline Uranium-235 & 210 & 85 & $6(x)$ & Sys & 420 \\
\hline Uranium-238 & 810 & 320 & (4099 & X & 1600 \\
\hline
\end{tabular}

* $5 \mathrm{pCi} / \mathrm{g}$ guideline for ${ }^{226} \mathrm{Ra}$ and ${ }^{228} \mathrm{Ra}$ may apply (DOE Order 5400.5). 


\section{Implementation}

The approach proposed here should be performed as part of the Feasibility Study (FS) phase of a CERCLA investigation when alternate remedies are identified and evaluated, and carried into the final cleanup stage when ALARA assessments are performed and documented. The net benefit analyses recommended here are meant for application in the detailed analysis of alternatives that is done in the FS, but a more qualitative assessment could also be used in the initial screening of alternatives. A calculation of the net benefit for each remedial alternative should be done to help choose among alternatives.

An analysis of the net benefits associated with excavation of all contaminated soils above commercial/industrial guidelines at the HWMF found high costs and small benefits. BNL's proposed plan for remediation of radiologically contaminated soils is to:

1) Excavate or vitrify in-place only highly contaminated soils at HWMF. Cap area that exceeds the commercial/industrial cleanup level for Cs-137.

2) Determine excavation level using failure analysis of the cap and assuming residential use after 50 years ( 75 mrem dose limit).

3) Excavate Cs-137 and $\mathrm{Sr}-90$ contaminated soils in other places onsite to residential guidelines. Consolidate excavated soils under the capped area at HWMF.

4) Excavate and dispose of soils at Building 650 (various radionuclides, with higher contamination levels than other soils) to residential cleanup guideline.

Recommended soil remediation guidelines at BNL were based on an exposure limit to future residents or workers of $15 \mathrm{mrem} / \mathrm{y}$ after 50 years of institutional control. For most soils on the BNL site contaminated with radionuclides, Cs-137 is the dominant radionuclide. Remediation guidelines have thus been based on this radionuclide. For the Building 650 sump in OU IV, however, a broad mix of radionuclides exists. Individual remediation guidelines were developed for each radionuclide. Remediation criteria will be based on the weighted sum of the radionuclides. These guidelines assume exposure from all radionuclides are limited to $15 \mathrm{mrem} / \mathrm{y}$. DOE may decide to use the $5 \mathrm{pCi} / \mathrm{g}$ guideline for radium, consistent with DOE Order 5400.5. This applies only to the Building 650 sump where radium is found above background concentrations. 


\section{References}

Baum, J., 1994, Value of Public Health and Safety Actions and Radiation Dose Avoided, prepared for the U.S. Nuclear Regulatory Commission by Brookhaven National Laboratory, Upton, New York, NUREG/CR-6212, BNL-NUREG-52413.

BNL, 1995, Future Land Use Plan, Brookhaven National Laboratory, Upton, New York, BNL-62130.

BNL, 1996, Brookhaven National Laboratory, Operable Unit IV, Draft Record of Decision, January 19, 1996, Office of Environmental Restoration, Brookhaven National Laboratory; Brookhaven Area Office, U.S. Department of Energy, Upton, New York.

Central Pine Barrens Joint Planning and Policy Commission, 1995, Central Pine Barrens Comprehensive Land Use Plan, Volume 2: Existing Conditions, Central Pine Barrens Joint Planning Commission, Great River, New York.

EPA, 1989, Risk Assessment Guidance for Superfund Vol. 1: Human Health Evaluation Manual (Part A), U.S. Environmental Protection Agency, Washington, D.C., EPA 540/1-89/002.

EPA, 1991, Risk Assessment Guidance for Superfund (RAGS) Human Health Evaluation Manual, Part B - Development of Risk-Based Preliminary Remediation Guidelines, U.S. Environmental Protection Agency, Washington, DC. OSWER Directive 9285.7-01B.

EPA, 1995, Radiation Site Cleanup Regulation 40 CFR 196 (preliminary staff working draft), U.S. Environmental Protection Agency, Washington, D.C.

Federal Register, 1991, Environmental Protection Agency, National Primary Drinking Water Regulations; Radionuclides, 40 CFR Parts 141,142, 56:138:33050.

ICRP, 1991, "1990 Recommendations of the International Commission on Radiological Protection", Publication 60, Annals of the ICRP, 21:1-3, Pergamon Press, Oxford.

NCRP, 1993, Limitation of Exposure to lonizing Radiation, National Council on Radiation Protection and Measurements, NCRP Report No. 116, Bethesda, Md.

NYSDEC, 1993. Cleanup Guidelines for Soils Contaminated with Radioactive Materials, Technical Administrative Guidance Memorandum No. 4003, New York State Department of Environmental Conservation.

Yu. et al., 1993. Manual for Implementing Residual Radioactive Material Guidelines Using RESRAD Version 5.0, Argonne National Laboratory, Environmental Assessment Division, ANL/EAD/LD-2. 


\section{INTRODUCTION}

Past activities at Brookhaven National Laboratory (BNL) resulted in soil and groundwater contamination. As a result, BNL was designated a Superfund site under the Comprehensive Environmental Response Compensation and Liability Act (CERCLA). BNL's Office of Environmental Restoration (OER) is overseeing environmental restoration activities at the Laboratory, carried out under an Interagency Agreement (IAG) with the United States Department of Energy (DOE), the United States Environmental Protection Agency (EPA), and the New York State Department of Environmental Conservation (NYSDEC).

With the exception of radium, there are no regulations to establish cleanup guidelines for radionuclides in soils at BNL. BNL must derive radionuclide soil cleanup guidelines for a number of Operable Units (OUs) and Areas of Concern (AOCs). These guidelines are required by DOE under a proposed regulation for radiation protection of public health and the environment (10 CFR Part 834) as well as to satisfy the requirements of CERCLA.

Site cleanups under Superfund must meet identified ARARS (Applicable or Relevant and Appropriate Regulations). When no ARARS are available, guidelines and nonpromulgated regulations are to be considered (TBC), and remedies are selected such that "the excess risk from any medium to an individual exposed over a lifetime generally falls within the range from $10^{-6}$ to $10^{-4 n}$ (preamble to the National Contingency Plan (NCP), Federal Register 8686, March 8, 1990).

Application of the RESRAD (Residual Radioactive Material Guidelines, Yu et al., 1993) computer code constrained by a dose limit of $30 \mathrm{mrem} / \mathrm{y}$ is a standard approach used at DOE sites to derive remedial guidelines for radionuclides in soil. When faced with the absence of ARARS, a number of DOE sites have derived remedial guidelines by limiting risks to potential receptors (recreational users, trespassers, residents) to the range required by Superfund (generally $10^{-6}$ to $10^{-4}$ ) using United States Environmental Protection Agency (USEPA; EPA 1991a) methods rather than the RESRAD code.

The objective of this report is to propose a standard and explicit approach to deriving risk-based cleanup guidelines for radionuclides in soil at BNL. Implementation of the approach is briefly discussed. ${ }^{1}$

\footnotetext{
${ }^{1}$ The approach suggested here was generally adopted by BNL and DOE in deriving soil cleanup guidelines, but some specific parameters and assumptions were modified in response to regulatory agency and DOE concerns.
} 
Several assumptions form the cornerstone of an approach to deriving cleanup guidelines:

- the dose limit applied to control exposure and risk from residual radioactive material;

- the land use scenarios and exposure parameters used in the analysis of exposure, dose and risk to potential future receptors; and

- the length of institutional control period assumed.

The approach described here also considers the costs and net benefits of remediation to the derived cleanup guidelines, and uses DOE's guidelines for applying the ALARA process to cleanup of the environment.

This report reviews proposed regulations and approaches taken at other DOE facilities; suggests a specific approach to deriving soil cleanup guidelines for BNL; documents the technical bases for the approach; and presents guidance for its implementation. The proposed approach and the major assumptions behind it are outlined in Section 2.

Sections 3 through 7 document and support the recommended approach to deriving soil cleanup guidelines by providing background information and the rationale for the selected approach. Section 3 summarizes the current situation at BNL in terms of the CERCLA cleanup and land use, and describes the land use plan for the site after closure. Section 4 documents situations where DOE and regulatory authorities have accepted land use assumptions other than a residential or residential farmer scenario; and presents reasonable land use scenarios, exposure pathways and parameters for BNL. Section 5 gives the bases for the dose limit to be used in deriving soil cleanup guidelines and Section 6 presents a general discussion of net benefit analysis and ALARA (As Low As Reasonably Achievable). Section 7 describes the approach suggested to assess potential impacts to groundwater. Section 8 gives guidance on implementing the proposed approach for a particular site at BNL.

Implementation of the approach is underway, and is discussed briefly in Section 9. 


\section{PROPOSED APPROACH FOR DERIVING RADIONUCLIDE SOIL CLEANUP GUIDELINES}

\section{Approach}

The approach proposed here should be performed as part of the Feasibility Study (FS) phase of a CERCLA investigation when alternate remedies are identified and evaluated, and carried into the final cleanup stage when the ALARA assessments are performed. The recommended net benefit analyses are meant for application in the detailed analysis of alternatives done in the FS, but a more qualitative assessment could also be used in the initial screening of alternatives. A calculation of the net benefit for each remedial alternative should be done as part of the FS phase of a CERCLA remedial action to help choose between alternatives. This approach provides methods to estimate the net benefit of a remedial alternative, and factors into the decision on the final option the level of protectiveness (i.e. dose limit and land use assumptions) embedded in the remedial guidelines for residual radioactivity in soil.

In the proposed approach, outlined in Figure 2-1, the RESRAD model (Yu et al., 1993; Version 5.61) is used to calculate allowable residual concentrations of specific radionuclides in soil at BNL. Preliminary remediation guidelines are derived using a dose limit for the public of $15 \mathrm{mrem} / \mathrm{y}$ above background together with scenario parameters for the land use planned for after site closure (BNL, 1995) and a $75 \mathrm{mrem} / \mathrm{y}$ dose limit to a suburban resident for scenarios other than residential and when active controls are to be used. The potential impacts to groundwater associated with the preliminary guidelines are assessed using the simple groundwater model in RESRAD. More sophisticated, site specific models are used when the RESRAD analysis suggests that preliminary guidelines could cause MCLs to be exceeded.

When Cs-137 is the dominant radionuclide, guidelines can be based on the single radionuclide criteria derived for $\mathrm{Cs}-137$. Because $\mathrm{Sr}-90$ usually occurs with $\mathrm{Cs}$ in contaminated soils at BNL, potential groundwater impacts associated with residual $\mathrm{Sr}-90$ concentrations in soil must be assessed. When other radionuclides are present in significant concentrations, the guideline for each radionuclide must be based on the weighted sum of the radionuclides in the mixture as described in Yu et al. (1993).

Remedial alternatives that depend on cleanup guidelines are then assessed in terms of the net benefit of cleanup to the preliminary guidelines. Costs of cleanup, potential ecological impacts and additional risks to the public and to remediation workers are compared to the number of cancers averted from performing the cleanup and to the costs associated with long term monitoring and maintenance of institutional controls. 
Figure 2-1. Proposed approach for deriving cleanup guidelines for radionuclides in soils at BNL.

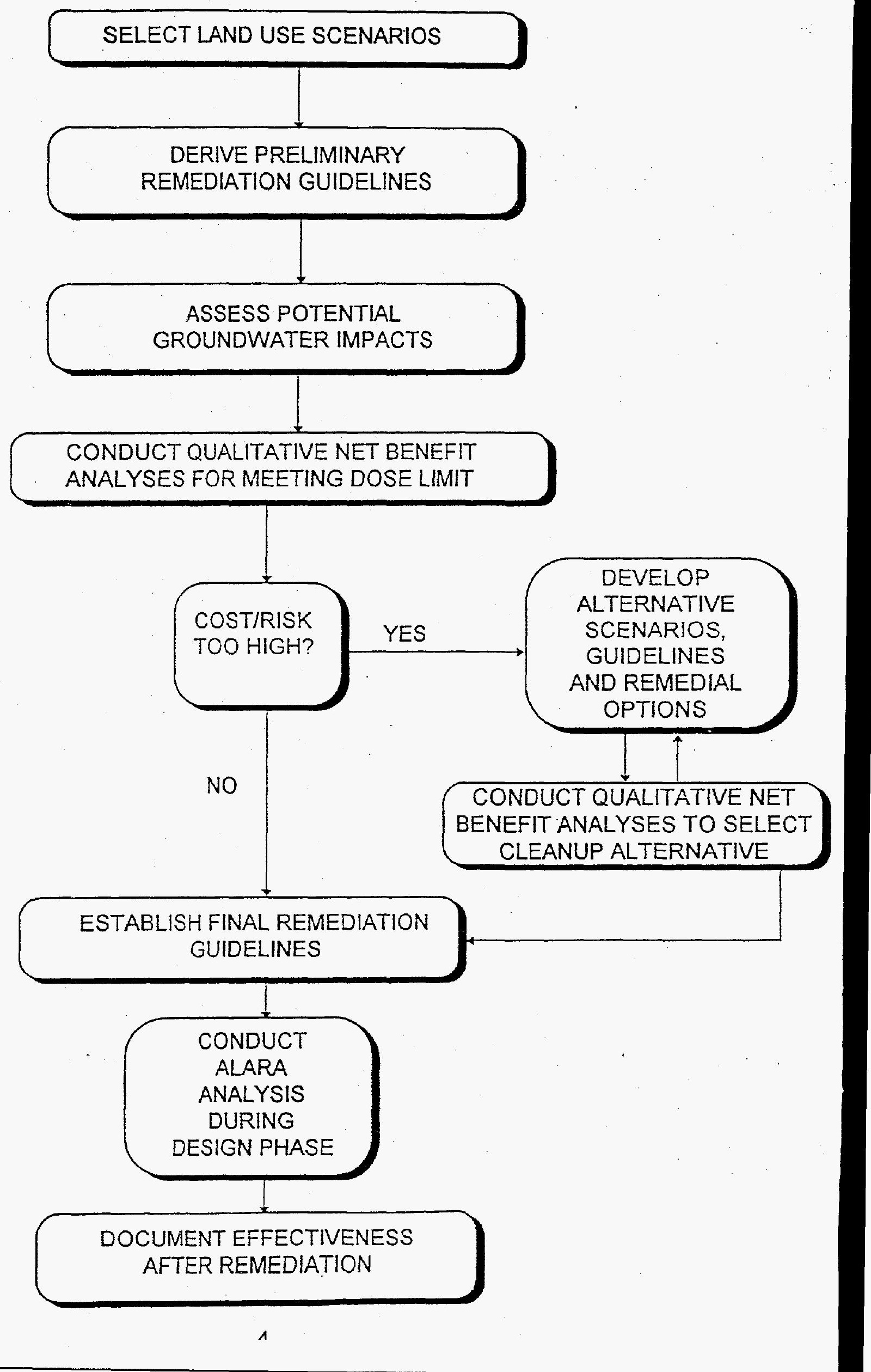


If the costs and risks associated with the preliminary guidelines are reasonable or acceptable for a particular cleanup option that also meets the nine criteria defined by EPA (threshold, balancing and modifying criteria, National Contingency Plan; NCP, 40 CFR 300.430, Table 2-1), they are accepted as final (along with the specific remedial option). An ALARA process is used during the design phase to cost-effectively reduce exposures to a reasonable level below the final dose limit. After the cleanup process is complete, a formal process is used to document that a reasonable reduction of radiation exposures was achieved and that they are ALARA.

When feasible, BNL will meet a dose limit of $15 \mathrm{mrem} / \mathrm{y}$ assuming the institutional control associated with land uses other than rural residential use, and $75 \mathrm{mrem} / \mathrm{y}$ for suburban residential use assuming failure of these institutional controls. When the $15 \mathrm{mrem} / \mathrm{y}$ guideline for alternatives involving excavation is associated with unacceptable potential damage to ecological values, additional risks to the public or workers, or costs, BNL should base the cleanup guidelines on an alternate scenarios/dose limit combination that protects the public to at least $75 \mathrm{mrem} / \mathrm{yr}$. In this situation, alternatives that do not involve soil excavation (e.g. capping, fencing) will be considered.

The major assumptions of the approach are described in more detail below. The technical bases for these decisions are given in Sections 3 through 7.

\section{Assumptions and Considerations}

\section{Dose Limits vs. Soil Concentrations}

The cleanup guidelines for radionuclides in units of $\mathrm{pCi} / \mathrm{g}$ of soil are derived assuming a dose limit of $15 \mathrm{mrem} / \mathrm{y}$ above background levels (approximately $2.3 \times 10^{-4}$ individual lifetime fatal cancer risk for a 30 year exposure) using the RESRAD model. The primary cleanup guideline is a dose/risk limit rather than a soil concentration because:

- Radionuclides have different chemical and physical properties, which result in differences in the likelihood they will be transported to groundwater or enter the food chain;

- Emissions from radionuclides are of different types and energies which results in differences in the level of exposure and risk posed to human health and the environment;

- Most radioactively contaminated sites contain a mixture of radionuclides with varying concentrations; and

- The level of exposure experienced by a receptor will vary depending on the way the land is used. 
Table 2-1. Evaluation Criteria (NCP, 40 CFR 300.430).

Threshold Criteria

Compliance with ARARs

Addresses whether a remedy will meet all of the ARARs of federal and state environmental laws and/or justifies a waiver.

Overall protection of Human Health and the Environment

Addresses whether a remedy provides adequate protection of human health and the environment and describes how risks posed through each exposure pathway are eliminated, reduced, or controlled through treatment, engineering controls or institutional controls.

Primary Balancing Criteria

Short-term effectiveness

Addresses the period of time needed to achieve protection and to determine any adverse impacts on human health and the environment that may be posed during the construction and implementation period, until remedial action objectives are achieved.

Long-term effectiveness

Refers to expected residual risk and the ability of a remedy to maintain reliable protection of human health and the environment over time.

\section{Reduction of toxicity, mobility, or volume}

Refers to the anticipated performance of the treatment technologies.

Implementability

The technical and administrative feasibility of a remedy, including the availability of materials and services needed to implement a particular option.

Cost

Includes estimated capital and operation and maintenance costs, also expressed as net present value.

Modifying Criteria

State acceptance

Indicates whether based on its review of the RI/FS and Proposed Plan, the state concurs with, opposes, or has no comment on the preferred alternative.

\section{Community acceptance}

Summarizes the public's general response to the alternatives, based on public comments received during the public comment period. 
The most consistent and cost-effective way of dealing with mixtures of radionuclides in soils is to cleanup to a single target dose level $(\mathrm{mrem} / \mathrm{y})$ which can be related directly to risk. For a given mixture of radionuclides at a site, transport and dose models are used to estimate the residual concentrations of the radionuclides required to reach the target dose level. These models require assumptions concerning the target dose level for cleanup, as well as the future land use and associated exposure parameters.

Because of differences in planned future land uses across the BNL site, different mixtures of radionuclides, and differences in the size and nature of the source terms and site specific hydrological conditions, cleanup guidelines will likely vary across the site. To reduce the confusion and complications associated with many different cleanup guidelines, generic preliminary cleanup guidelines were derived for BNL. These generic guidelines are given in Section 8 and were derived using conservative boundary conditions and assumptions and represent average site hydrological conditions. They will not always be appropriate because of site specific conditions (such as varying depth to groundwater), but provide a consistent starting place from which more accurate, site specific analyses can be performed if needed.

\section{Land Use and Exposure Scenarios}

The scenarios characterize the future land-use pattern for the site and surrounding area. The land use that requires the most stringent cleanup criteria is generally considered to be the resident farmer. If the site is cleaned up such that this family is below the maximum tolerable risk level, it is generally considered acceptable for unrestricted use.

Based on current land uses near the BNL site, local controls on development and the BNL future land use plan (BNL, 1995), a residential farmer scenario is not a reasonable assumption to form the basis of remedial guidelines. The land use types described in the BNL future land use plan for the post-closure scenario (BNL, 1995) should be used to derive remedial guidelines for cleanups at specific site locations.

Future uses of the site will probably not include exposures to groundwater, because any future receptors are expected to have access to public water. Ingestion of drinking water as an exposure pathway was included at the insistence of the regulatory agencies for residential, commercial and recreational uses.

Four scenarios were developed for the BNL site: suburban residential; commercial/industrial; and two open space scenarios, one an undeveloped park and one a developed park. Most of the land on the BNL site is undeveloped. The BNL Future Land Use Plan (BNL, 1995), which was developed with extensive community involvement, determined that future land use at BNL would be primarily open space. Much of the open space on the BNL site is designated as part of the protected core area of the Long Island Pine barrens (Central Pine Barrens Joint Planning and Policy Commission, 1995). 
EPA agreed that the likely future land use for the BNL site was open space. EPA insisted, however, that soil remediation guidelines be based on either residential or commercial/industrial land use. Their rationale for this was that, although the public was highly involved in the BNL Future Land Use Planning process, they did not realize at the time that one implication of an open space land use was that soil remediation requirements would be less stringent then residential or commercial. If the actual land use for most of the site is open space, use of residential or commercial/industrial assumptions in developing soil remediation guidelines will introduce a considerable additional margin of safety.

Because of the importance of the aquifer underlying BNL as a future resource, assessing potential impacts to groundwater is an important part of the approach for deriving soil cleanup guidelines for BNL.

Another important assumption in deriving soil cleanup guidelines for BNL is the length of institutional control that should be assumed before release of the site for its planned future uses. Soil cleanup guidelines can be developed to result in a $15 \mathrm{mrem} / \mathrm{y}$ dose limit to receptors assuming the planned land use begins immediately after cleanup or at some time in the future when the site is released for other uses. Since DOE has no plan to stop operations at BNL, some future time period for release of the site (e.g. 50 years) is a reasonable assumption. BNL used a 50 year period of institutional control in deriving preliminary guidelines for Operable Unit IV (BNL, 1996). This report presents generic soil cleanup guidelines assuming three time periods for release: current, 50 years in the future and 100 years in the future. RESRAD can be used to derive guidelines for other assumed periods of institutional control.

\section{Dose Limit for Derivation of BNL Cleanup Guidelines}

Except for radium (5 pCi/g; DOE Order 5400.5) no ARARS are available to guide cleanup of radionuclides in soil at BNL. EPA, DOE and the United States Nuclear Regulatory Commission (USNRC) are planning to promulgate regulations for residual radioactive material in soil. Relevant proposed regulations and New York State guidelines include:

- EPA Proposed Radiation Site Cleanup Regulation (40 CFR 196); meant for release of sites, $15 \mathrm{mrem} / \mathrm{y}$ above background that may be met by institutional controls; $75 \mathrm{mrem} / \mathrm{y}$ to rural resident if controls fail. MCLs (maximum contaminant levels) in groundwater must be met if practicable.

- DOE Proposed Regulation (10 CFR 834; Radiation Protection of the Public and the Environment); $100 \mathrm{mrem} / \mathrm{y}$ from all sources except background, medical and occupational exposures. Exposure from a single site should be $30 \mathrm{mrem} / \mathrm{yr}$. Limits for radionuclides in soils must be derived using approved models.

- New York State Administrative Guideline (Technical Administrative Guidance Memorandum; NYS, 1993; Soil Cleanup Guidelines for Radioactive Material). The guideline suggests a dose limit of $10 \mathrm{mrem} / \mathrm{y}$, 
is meant for release of sites, and allows consideration of institutional controls.

EPA found that a dose limit of $10 \mathrm{mrem} / \mathrm{y}$ would be difficult to measure, that it is low compared to the natural variation in natural background radiation that may be observed across a given site, and that costs were excessive and no deaths were averted (EPA, 1995a).

The $15 \mathrm{mrem} / \mathrm{y}$ limit is an extremely conservative limit that will be difficult to meet and does not consider the high costs and small benefits associated with meeting a dose limit so close to background. EPA has insisted that BNL derive guidelines based on a $15 \mathrm{mrem} / \mathrm{y}$ dose limit, and New York State requested a 10 $\mathrm{mrem} / \mathrm{y}$ limit.

\section{Impacts to Groundwater}

The aquifer underlying BNL has been designated a sole source aquifer; and assessing potential impacts to groundwater is an important part of the approach for deriving soil cleanup guidelines for BNL. Including the groundwater pathway in RESRAD does not guarantee that MCLs will be met -only that the specified total dose limit will be met for all pathways. RESRAD can be used as a screening tool to assess worst-case potential impacts, but it is too simple and conservative for more accurate analyses. Groundwater models already in use at BNL can be used to estimate potential impacts to groundwater when a RESRAD calculation suggests a potential problem.

\section{Approach}

In the proposed approach, when feasible, BNL will meet the proposed EPA dose limit of $15 \mathrm{mrem} / \mathrm{y}$ assuming the institutional control associated with land uses other than rural residential use, and $75 \mathrm{mrem} / \mathrm{y}$ for suburban residential use assuming failure of these institutional controls. When the 15 $\mathrm{mrem} / \mathrm{y}$ guideline for alternatives involving excavation is associated with unacceptable potential damage to ecological values, additional risks to the public or workers, or costs, BNL will base the cleanup guidelines on an alternate scenarios/dose limit combination that protects the public to at least $75 \mathrm{mrem} / \mathrm{yr}$. In this situation, alternatives that do not involve soil excavation (e.g. capping, fencing) will be considered.

The BNL assumptions differ from the proposed EPA rule in that the 75 $\mathrm{mrem} / \mathrm{y}$ dose limit associated with a loss of institutional control is assumed for a suburban resident rather than a rural resident because this is the most likely future residential land use near BNL.

Earlier guidelines derived for BNL have treated the $5 \mathrm{pCi} / \mathrm{g}$ limit for radium (DOE Order 5400.5) as a separate limit not included in the overall dose limit for radionuclides in soil (BNL, 1996). This approach suggests including the dose from radium in the overall dose limit as there is no risk-based reason to treat radium separately. DOE may decide to use the $5 \mathrm{pCi} / \mathrm{g}$ guideline for radium at BNL, which would be consistent with DOE Order 5400.5 . 
An ALARA process will be used during the design phase to costeffectively reduce exposures to a reasonable and safe level below the final dose limit. After remediation a process will be used to document that the residual levels are ALARA.

The proposed approach is to assess potential groundwater impacts in two steps:

- Use RESRAD to estimate the worst-case future concentration of radionuclides in groundwater beneath the waste site associated with a set of preliminary guidelines. Compare these concentrations to USEPA and NYS MCLS.

- If MCLs are exceeded in this analysis, perform a more detailed modeling analysis to estimate groundwater concentrations and doses for comparison to MCLs.

If this more accurate analysis suggests that MCLs may be exceeded, BNL should assess the net benefit associated with meeting MCLs, determine if meeting MCLs is practicable, and consider institutional controls that will eliminate the groundwater pathway. This decision should be made as part of the net benefit analysis performed on each set of preliminary guidelines.

\section{Implementation and Technical Basis}

Sections 3 through 7 document the recommended approach to deriving soil cleanup guidelines. Section 8 gives specific step by step guidance on implementing the suggested approach for a particular site at BNL. Implementation of the approach is underway, and is discussed briefly in Section 9. 


\section{CURRENT SITUATION AND FUTURE LAND USE PLAN}

A description of the current and potential future land use on and near the BNL site is central to the land use assumptions used in deriving soil cleanup guidelines. This section summarizes the current situation on and near BNL in terms of environmental restoration activities, the natural environment, current land uses and potential future use. This information was extracted from the BNL Future Land Use Plan (BNL, 1995), the BNL Site Environmental Report for Calendar Year 1993 (Naidu and Royce, 1994), and reports describing the environmental restoration program (SAIC, 1990).

\section{Brookhaven National Laboratory}

Brookhaven National Laboratory (BNL) is a multidisciplinary scientific research center located on Long Island, New York. BNL is operated by Associated Universities, Inc., (AUI) for the United States Department of Energy (DOE). The laboratory carries out basic and applied research in high-energy nuclear and solid state physics; fundamental material and structural properties and interactions of matter; nuclear medicine; biomedical and environmental sciences; and selected energy technologies.

\section{Natural Environment and Controls on Development}

Groundwater is the major source of drinking water on Long Island, and the aquifer beneath BNL is designated by the EPA as a "Sole Source Aquifer". Marshy areas in the northern and eastern sections of the site are part of the Peconic River headwaters. The Peconic River has been designated a "Scenic" River in accordance with the New York State's Wild Scenic and Recreational Rivers Act. These designations acknowledge the importance and uniqueness of BNL's local environment.

BNL is located in an ecologically important area on Long Island called the Central Pine Barrens Zone which covers approximately 100,000 acres in Suffolk County. The Long Island Central Pine Barrens region is a complex matrix of pitch pine woodlands, pin-oak forests, coastal plain ponds and swamps. The biota tends to be unusual, and includes many rare species (summary abstracted from Central Pine Barrens Joint Planning and Policy Commission, 1995). The Central Pine Barrens also encompasses regions of deep aquifer recharge.

The Pine Barrens Act (1993) defined two areas within the overall Central Pine Barrens Zone: the Core Preservation Area (about 52,500 acres) and the Compatible Growth Area. Within the Core Preservation Area, the principal guideline is to preserve its natural state; and development, construction and other activities are limited or prohibited. Developed areas of the BNL site are located in the Compatible Growth Area, and the undeveloped wooded areas are included in the Core Preservation Area (Figure 3-1). Approximately $54 \%$ of the BNL site is located in the Core Preservation Area. 


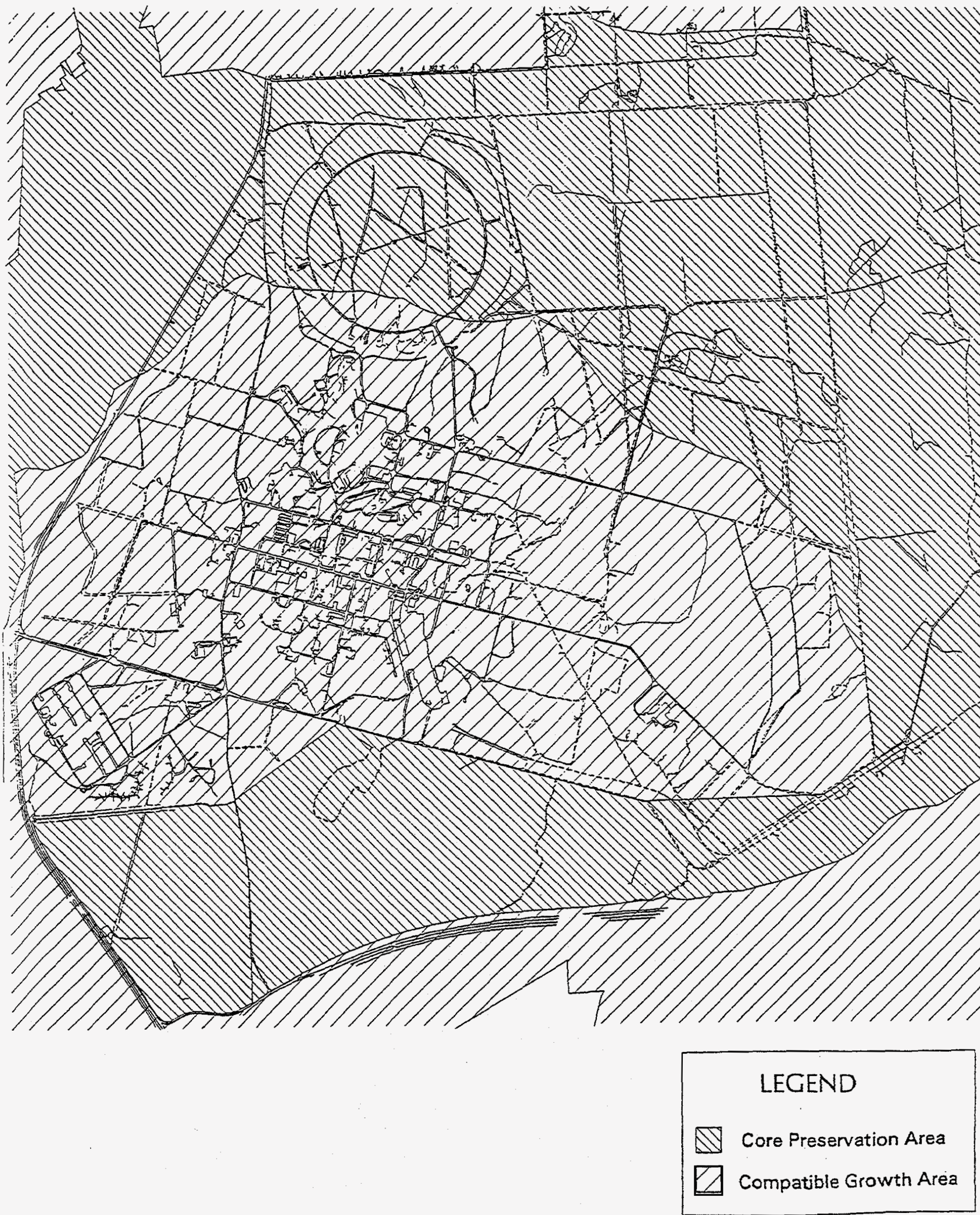

Figure 3-1. Pine Barrens Core Preservation Area on the BNL Site. 
Because of these unique characteristics of eastern Long Island, local governments are making efforts to channel growth in an orderly fashion. Planning is directed toward preserving the open wooded, agricultural and recreational areas. Park and farmlands are being purchased by local governments, private trusts and environmental organizations and zoning ordinances have been enacted to control population density.

\section{Current Land Use}

\section{Onsite}

The BNL site consists of $21.3 \mathrm{~km}^{2}(2,130 \mathrm{ha})$. Most of the property is wooded, except for a developed area in the middle of the site of about $6.7 \mathrm{~km}^{2}$ ( $670 \mathrm{ha})$, and outlying facilities $\left(2.2 \mathrm{~km}^{2} ; 222 \mathrm{ha}\right)$ including the sewage treatment plant, research agricultural fields, housing and fire breaks. The general location of the buildings, roads and utilities are a legacy of the former Camp Upton. Figure 3-2 shows current land use patterns at BNL.

Seventy-five percent of the site is in open space use. Most of the approximately 350 buildings and other structures are located in the developed area which is now designated for commercial/industrial use. Table 3-1 summarizes the area of land currently in open space, industrial/commercial, agricultural and residential use at BNL.

Table 3-1. Area in various land uses at BNL under current and planned postclosure future land use scenarios (calculated from maps in the BNL Future Land Use Plan, BNL, 1995).

\begin{tabular}{|l|c|c|c|c|}
\hline \multirow{2}{*}{ Land Use } & \multicolumn{4}{c|}{ Scenario } \\
\hline & \multicolumn{2}{|c|}{ Current } & \multicolumn{2}{c|}{ Post-closure } \\
\cline { 2 - 5 } & $\mathbf{k m}^{2}$ & ha & $\mathbf{k m}^{2}$ & ha \\
\hline Open Space & 16.5 & 1648 & 14.6 & 1457 \\
\hline Industrial/Commercial & 3.8 & 376 & 4.5 & 447 \\
\hline Recreational & 0 & 0 & 1.4 & 137 \\
\hline Residential & 0.7 & 72 & 0.9 & 90 \\
\hline Agricultural & 0.3 & 34 & 0 & 0 \\
\hline
\end{tabular}


Potable water at the laboratory is drawn from deep wells that tap the Magothy aquifer. The water is monitored to ensure that all potable water meets Federal and State drinking water standards, and treated before use when necessary.

Offsite

Approximately 5 million people live within $80 \mathrm{~km}$ (50 mi ) of BNL (Naidu and Royce, 1994; calculated from their Figure 1). Approximately 7,000 people live within $0.5 \mathrm{~km}(0.3 \mathrm{mi})$ of BNL (Naidu and Royce, 1994; calculated from their Figure 2; includes assumed onsite population). To the north and west of the site, the land is mostly wooded, privately owned and zoned for residential development. Much of the land within $16 \mathrm{~km}$ (10 miles) of the Laboratory remains forested or under cultivation, but there has been an increase in residential housing development surrounding BNL.

Parkland, airports and recreational and educational facilities account for about $32 \%$ of the local area; another $30 \%$ is in undeveloped woodland or farms (BNL, 1995). The remaining $38 \%$ consists of areas developed or zoned for business, industry or residential use. The area surrounding the Laboratory is still generally lightly settled, with high density areas located directly to the south.

A large percentage of houses in Suffolk County are serviced by municipal water, but many residences in eastern Long Island use private wells that tap the shallow Glacial Aquifer.

\section{Future Land Use}

Onsite

The Laboratory has no plans for closing or decommissioning the site. There is a long-range (20 year) master plan for the Laboratory. In this plan, the future development of the site will be based on the continued need for large, complex research facilities in a variety of fields of science and technology. BNL (1995) describes two possible alternate growth scenarios over the next 20 years. In both cases, open space may be reduced by up to $20 \%$. Additional development within the currently designated industrial/commercial areas is expected. No expansion of the area used for agriculture or residences is expected.

In cooperation with stakeholders, BNL developed a post-closure land use plan (BNL, 1995; Figure 3-3) Most open space would remain as such, and could be divided into passive and active recreational uses. The housing facilities could be maintained as residential use. The developed areas onsite would remain in industrial/commercial use. Table 3-1 summarizes the size of the areas planned for open space, industrial/commercial, residential and recreational use after closure of the laboratory. 


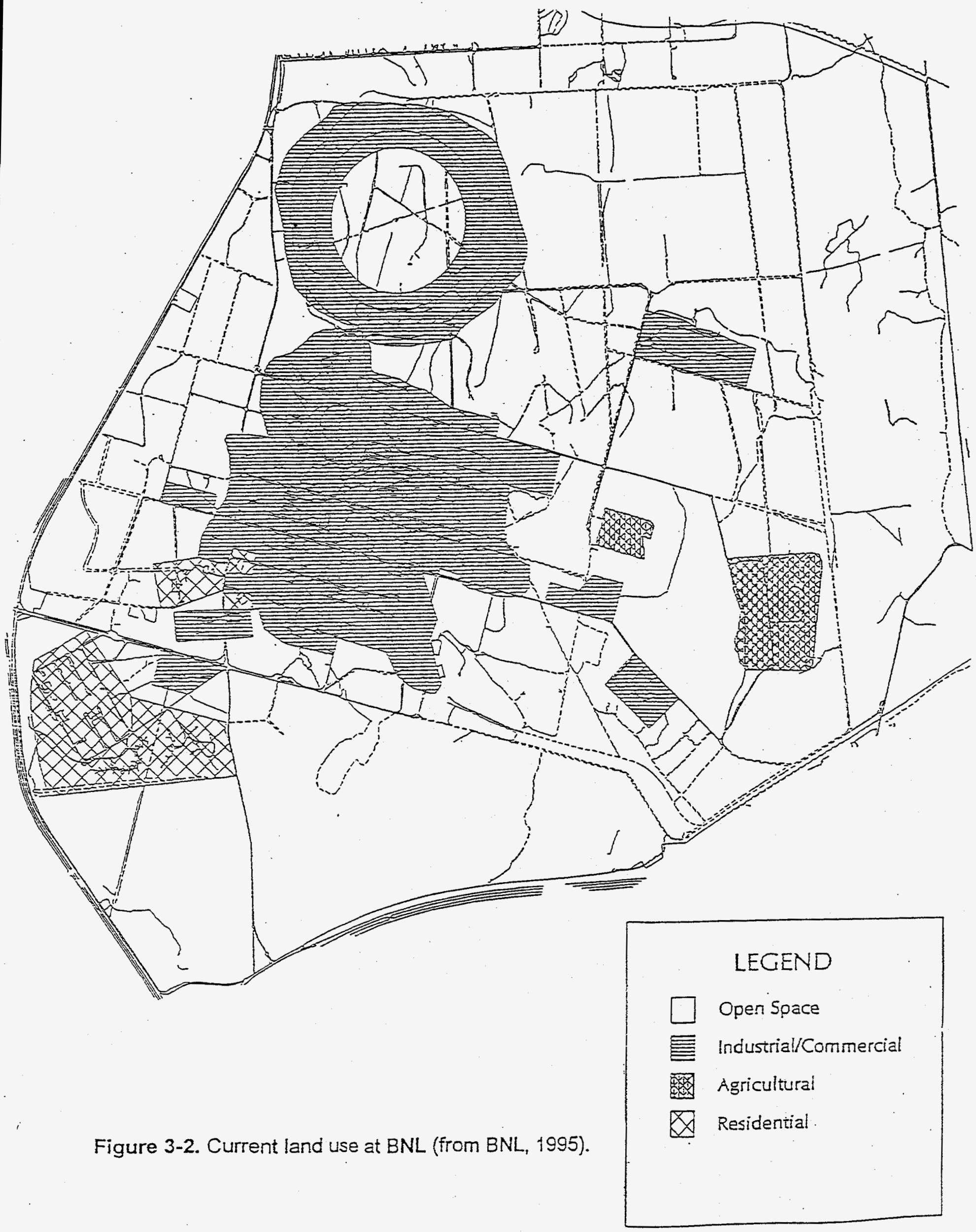




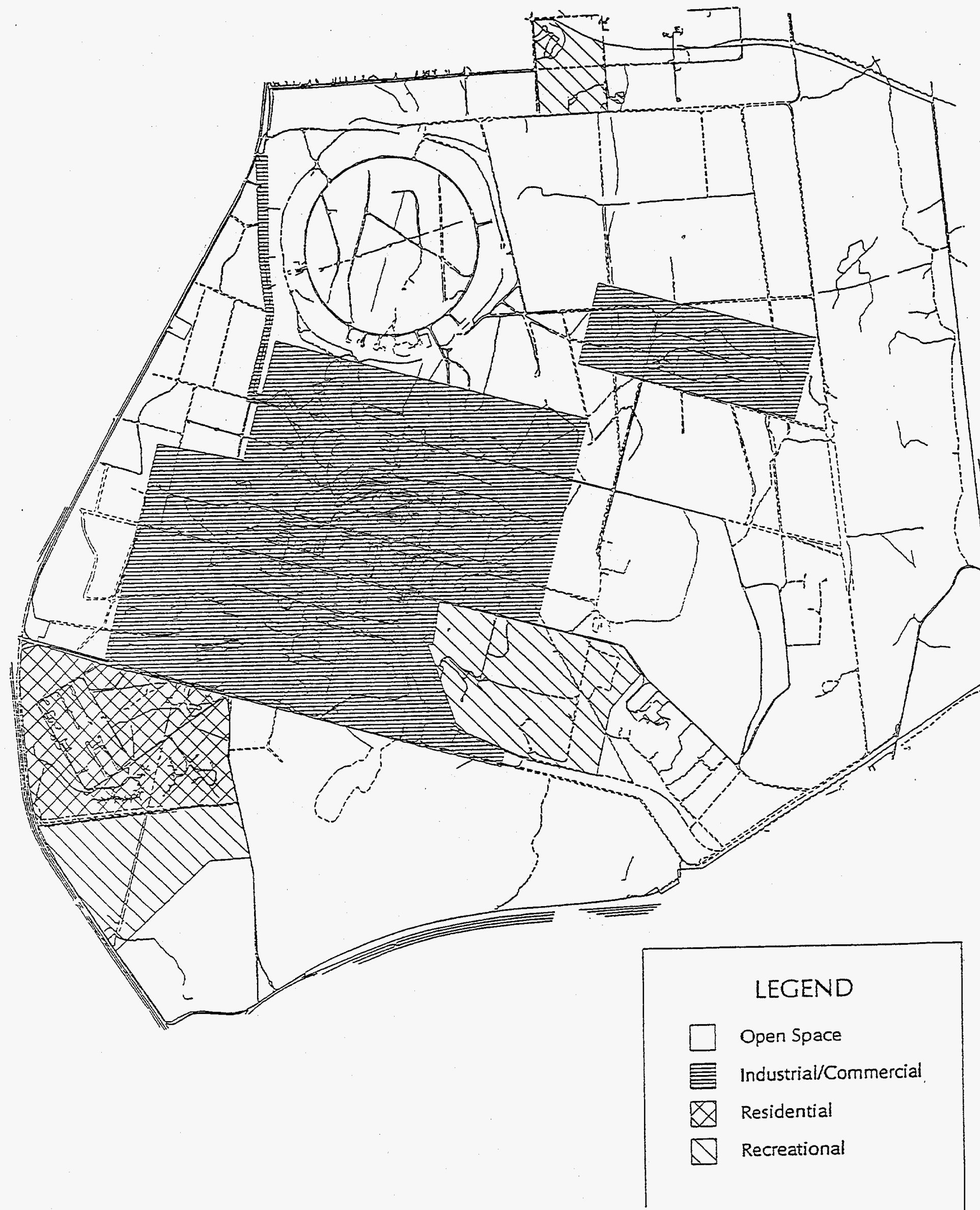

Figure 3-3. Planned future land use (post-closure; from BNL, 1995). 


\section{Offsite}

There are detailed plans for two shopping centers, a corporate park, and several thousand single and multiple family dwellings proposed within a $15 \mathrm{~km}$ area of the Laboratory, predominantly on the north, south and west boundaries. The area to the east of the Laboratory remains sparsely populated, and is zoned for low density residential and open space use (BNL, 1995).

Because of the emphasis on open space preservation on eastern Long Island, especially within the Pine Barrens Core Preservation Area, development to the east of the Laboratory is likely to be minimal. There is pressure for residential development in areas close to $\mathrm{BNL}$, and additional agricultural uses are not likely.

The Suffolk County Water Authority (SCWA) has plans for additional water mains to the south and east of the Laboratory, and the Suffolk County Department of Health Services (SCDHS) requires that new individual houses within 150 feet of a main connect to the municipal source. SCDHS also requires connection to municipal water for new housing developments. Most future residential development will be serviced by municipal water.

\section{Environmental Restoration Activities}

Past activities at BNL resulted in soil and ground water contamination. As a result, BNL was designated a Superfund site under the Comprehensive Environmental Response Compensation and Liability Act (CERCLA). BNL's Office of Environmental Restoration (OER) is overseeing environmental restoration activities at the Laboratory, carried out under an Interagency Agreement (IAG) with DOE, the USEPA and the New York State Department of Environmental Conservation (NYSDEC).

Approximately 30.25 ha (1.4\%) of the BNL property is contaminated with low level radionuclides in soil above background (calculated from map presented in the BNL Future Land Use Plan, BNL, 1995).

There are currently twenty-four AOCs (areas of concern) to be addressed through the IAG. The AOCs consist of both active and inactive facilities. The AOCs have been grouped and prioritized into operable units (OUs) and removal actions (RAs).

Removal actions (RAs) are given highest priority and include:

- Removal of three above ground and thirteen underground storage tanks;

- Decontamination of cesspools at twenty-four buildings;

- Treatment of ground water associated with an earlier spray aeration project; 
- Cleanup of former landfills and associated disposal areas; and

- Remediation of soils and/or groundwater contaminated with volatile organic compounds (VOCs).

Restoration at the five OUs involves characterizing environmental problems, selecting and implementing a remediation strategy, and follow-up environmental monitoring. The OUs at BNL consist of :

- OU INI encompasses the southeastern quarter of the site and consists of several AOCs, including the hazardous waste management facility and two former landfill areas.

- OU IINII covers the central core area of the site and consists of various areas where low level radioactive materials are or were handled and stored. These include the Waste Concentration Facility, scrapyards for steel from the Alternating Gradient Synchrotron (AGS), a former test area adjacent to the Low Mass Criticality Facility and various areas where soil is contaminated with low levels of radioactivity.

- OU III focuses on known or suspected groundwater contamination from waste disposal, accidental spills and past routine releases not included in the other OUs.

- OU IV is located in the east-central portion of the site. It includes the Central Steam Facility, where fuel spills have occurred, and the Reclamation Facility, an area where radiological decontamination is performed.

- OU V encompasses the northeastern portion of the laboratory and focuses on the Sewage Treatment Plant. There is also a Satellite Disposal Area which was used to dispose of unknown chemicals and leaking gas cylinders in the 1960 s.

\section{Radiologically Contaminated Soils}

Approximately 30.25 ha (1.4\%) of the BNL property is contaminated with detectable concentrations of radionuclides in soil above background. These soils are located in several operable units (OUs). Radiologically contaminated soils will all be addressed under one Feasibility Study and final remedial action. Radiologically contaminated soils at BNL can be grouped into three categories:

\section{Hazardous Waste Management Facility (HWMF)}

The HWMF was the central receiving and storage facility for radioactive materials and waste at BNL for 50 years. Soils in the HWMF contain significant radiological contamination. Cesium- 137 is the dominant radionuclide with a maximum reported concentration of $810,000 \mathrm{pCi} / \mathrm{g}$. Strontium-90 is the second most prevalent radionuclide in the HWMF with a maximum soil concentration of $1300 \mathrm{pCi} / \mathrm{g}$. Approximately 35,000 cubic yards of soil at the HWMF may require remediation. 


\section{Other Radiologically Contaminated Soils}

There are several smaller areas of low-level radiologically contaminated soils scattered around the facility. All of these are dominated by $\mathrm{Cs}-137$ and $\mathrm{Sr}-90$, and have smaller concentrations than those found at the HWMF. Maximum Cs137 concentrations in these soils are less than $600 \mathrm{pCi} / \mathrm{g}$.

\section{Building 650}

Building 650 was a decontamination facility for the removal of radiation from clothing and heavy equipment. The mix of radioactively contaminated soils at Building 650 is different than that of other radiologically contaminated soils at BNL. In addition to elevated Cs-137 and Sr-90, these soils contain Eu-152, Eu154, Eu-155, Ra-226, Am-241, U-234, U-235, U-238, Pu-238, Pu-239, Pu-240, $\mathrm{Na}-22$, and $\mathrm{Co}-60$. Approximate maximum soil concentrations are: $\mathrm{Cs}-137: 1800$ pCi/g; Sr-90: 147 pCi/g, Ra-226: 63 pCi/g, Co-60: 24 pCi/g, Pu-239: 250 pCi/g, Eu-152: $580 \mathrm{pCi} / \mathrm{g}$ and Eu-154: $350 \mathrm{pCi} / \mathrm{g}$. 


\section{ALTERNATIVE SCENARIOS AND EXPOSURE PARAMETERS FOR SITE CLEANUP}

\section{Introduction}

Planning and designing a site cleanup requires development of specifications such as the permitted residual level of each radiological contaminant in soil and water, e.g., $\mathrm{pCi} / \mathrm{g}$ or $\mathrm{pCi} / \mathrm{L}$. These specifications are developed from four kinds of information: environmental exposure pathways, expected land-use pattern, cleanup cost, and the level of residual risk (or dose) that will be tolerated. These are not completely independent. Environmental exposure pathways depend primarily on site characteristics, although they can be affected by human activity. The level of risk that will be tolerated is generally established independently, but may be dependent on cost.

The scenarios characterize the future land-use pattern for the site and surrounding area. The land use that requires the most stringent cleanup criteria is generally considered to be the resident farmer. This is a family spending a substantial portion of time outdoors on the land, in contact with soil, who grow a substantial percentage of their food on the land, produce meat, poultry and milk, and whose drinking water comes from a private well tapping groundwater beneath the site. Their level of exposure is high in terms of time and pathways. If the site is cleaned up such that this family is below the maximum tolerable risk level, it is generally considered acceptable for unrestricted use.

Until recently, the regulatory approach adopted by EPA and other regulators was that a site must meet the resident farmer criteria. Several factors, however, have led to a change in that thinking.

First was that old commercial or industrial sites in cities were being abandoned because the cost of meeting this criteria was too high. EPA recognized that the residential farmer scenario was inappropriate for these sites and initiated a program to make environmental cleanup a building block to urban economic development instead of a road block. This was the Brownfields Action Agenda, so called as a contrast to the earlier guideline that all contaminated sites would be turned into greenfields. In 1995, fifteen cities across the country were selected for brownfields pilot projects. Brownfields did not mean that a higher level of risk was being accepted. No one would be growing food on these commercial or industrial sites or drinking the underlying water. Children would not be in the backyard playing in the dirt. People would be there for the workday, or for a few hours shopping, not living there. This land use scenario thus reduced the possible pathways of exposure and the time people were exposed. The same risk level could be achieved with less stringent cleanup specifications and lower cost.

For DOE sites, public outreach programs involved community organizations in plans for future land use. There seems to have been an expectation within the DOE community that, if the government were to release 
these properties, there would be a scramble among housing developers to cover them with subdivisions. That is not, however, what resulted from the public outreach. People wanted these properties maintained as open space. This is not surprising when one considers what these sites are. The large DOE sites, including the national laboratories and the large production facilities such as Savannah River, Rocky Flats, and Hanford, consist primarily of undeveloped open space. Government control has preserved these sites from the development that has in many cases swallowed up the surrounding land. People recognize the value of maintaining this open space. Like Brownfields, an open space scenario eliminates some exposure pathways and reduces the time people are exposed. The character of the exposure is different than for commercial or industrial land use. Indeed, there are several alternative open space scenarios that range from intensive recreational use such as ball fields to wildlife preserves.

Related to open space is the issue of environmental restoration vs. environmental remediation. EPA, in their draft radiation site cleanup regulation, states that, although the standard was set at a level to protect human health, it is also protective of many ecological receptors (EPA 1995a, p. 24). They cite an ICRP statement that environmental control needed to protect man will ensure that other species are not put at risk (EPA, 1995a, p. 25; ICRP, 1991). These statements reflect the belief that other species will not be affected by radiation exposures within the limits that are designed to protect people. The principal approach to cleanup of contaminated soil, however, is to dig it up and cart it to a disposal site. The impact on the ecology is not from radiation effects, but from the destruction of habitat. If a guideline is to preserve the ecological characteristics of the site, soil excavation is an inappropriate solution. EPA recognizes that moving large volumes of soil can have adverse ecological impacts, but does not address that issue in their proposed regulation. In a later section (Section 7), this report discusses the need to balance public health risk, anticipated health effects to remediation workers, and ecological damage.

It may not be necessary, however, to tradeoff health risk to prevent ecological damage. Where other species are thriving under conditions that exceed the allowable exposures for residential use, one solution is to designate the area as an ecological or wildlife reserve. Public exposure would be inherently lower than in a residential area even if the radiation levels were higher, since the duration and frequency of exposure would be much less.

This section describes alternative land use scenarios used at other DOE sites, summarizes the bases for alternative land use scenarios in deriving soil cleanup guidelines for BNL, details reasonable land use scenarios and associated exposure pathways for the BNL site, and provides suggestions for exposure parameters appropriate for use at BNL. 


\section{Examples of Use of Alternative Scenarios at DOE Sites.}

DOE sites include large tracts of land that have been protected from development for over 40 years. The have become de facto ecological preserves. Areas on some DOE sites have been officially designated as ecological research areas. It should not be surprising that there is great incentive to preserve the character of these areas. Other DOE sites have characteristics that make the resident farmer scenario inappropriate. For example, the land may not be suitable to support agriculture. Some sites are highly industrialized facilities that are most suited for continual industrial use. Some examples include:

Mound Laboratory, Ohio

This is a highly industrialized facility that is being closed by DOE, but is planned for continued industrial use. The local community supports this since the site represents a major source of employment in the area (personal communication with R. Neff).

\section{Rocky Flats, Colorado}

Jefferson County, which includes Rocky Flats, passed a resolution to maintain part of the site in perpetuity as an undeveloped buffer zone of open space. Similar conclusions were made by a working group of stakeholders. DOE, EPA, and the Colorado Department of Public Health and Environment agreed that residential scenarios would be dropped from all buffer zone assessments and that new scenarios for open space would be developed, such as recreational or ecological study uses. The future use concept developed by DOE for the site includes, in addition to open spaces, areas where mining would be permitted, a transportation corridor and environmental technology areas. No residential land use is included (Hogg, 1995).

\section{Fernald Environmental Management Project (FEMP), Ohio}

The Fernald Citizens Task Force recommended that agricultural or residential use of the property be prohibited. An on-site disposal facility will be established that will remain under the continued ownership of the federal government. The rest of the site will be made available to the surrounding communities with an expectation of use as undeveloped parkland. Exposure scenarios were developed for a wildlife reserve, undeveloped parkland, and developed parkland (USDOE, 1994a).

\section{Hanford, Washington}

Four future land use options were recommended for the 100 Area at Hanford by the Hanford Future Site Advisory Group in 1992 (USDOE, 1995a). These recommended land uses were: 1) Native American uses; 2) limited recreation; 3) recreation-related commercial use; 4) use of the $B$ reactor as a museum and visitor center; and 5) wildlife use. In developing soil cleanup guidelines for the 100 Area, DOE found that differing land use assumptions had 
little effect on soil cleanup guidelines because groundwater usage was the major exposure pathway. Cleanup guidelines were developed for an unrestricted use (residential) scenario.

Idaho National Engineering Laboratory (INEL), Idaho

INEL is the site of the National Environmental Research Park. All land within the boundaries is a protected outdoor laboratory where scientists conduct ecological studies. INEL has developed a long-term land use plan (USDOE $1995 \mathrm{~b}$ ) that assumes that the site will remain under government management and control for at least the next 100 years. No residential development is expected for the site in the next 100 years.

\section{Lawrence Livermore National Laboratory (LLNL), California}

LLNL is a heavily developed site. Risk assessments for the LLNL site did not assume a future residential use scenario. It was assumed that DOE would retain ownership of the site for the foreseeable future (USDOE, 1992).

Unrestricted Use, Restricted Use, and Institutional Control at BNL

The Myth of Unrestricted Use

If clean-up were designed toward release of the BNL site for unrestricted use at some future date, proposed EPA guidance would suggest assuming a resident-farmer land use scenario (EPA, 1995a). EPA's rationale for this requirement is that it is more protective and that "... the majority of the sites that this rule would apply to are in rural locations that realistically could be converted into agricultural use." (p. 38). Even for an unrestricted use, this is not a realistic scenario for the BNL site. Farming is declining on Long Island, not growing. BNL is no longer in the country side; it is being rapidly surrounded by suburban growth with accompanying commercial and industrial development. A reasonable residential scenario would be suburban development, not a family farm. Meetings with stakeholders as part of the development of the future use plan (BNL, 1995) produced no suggestion of agricultural use. Advocates of residential land use proposed either institutional housing or low density residential zoning. It should be noted that low density residential zoning on Long Island does not indicate people who are subsisting on the land raising vegetables, poultry, etc.

In addition, any residential development of the BNL site would almost certainly mean provision of public water supply regardless of the quality of the groundwater underlying the site (see Section 3).

But even suburban development may not be the most likely future were the site to be released. The BNL site is located in the Long Island pine barrens, a valuable natural resource. As suburban development gradually nibbles away at the pine barrens, public understanding of the need to protect this resource has increased. The core area of the Pine Barrens (comprising approximately $54 \%$ of the BNL site) is protected by the State of New York (Central Pine 
Barrens Joint Planning and Policy Commission, 1995). Much of the BNL site remains close to its natural state and BNL plans to continue to preserve this status as much as possible while carrying out its DOE mission (BNL, 1995). The BNL Future Land Use Plan reflects the public expectation that the bulk of the site will remain open space.

What will dictate the use of the land when the BNL site is released? At this location, "unrestricted use" does not exist. The area is subject to the State Pine Barrens Plan, the Special Groundwater Protection Plan, the Long Island Comprehensive Wastewater Management Plan and local zoning controls. Wells may not be installed without a permit. Connection to a public water supply is mandatory for most new construction (Section 3).

\section{Restricted Use and Institutional Control}

Restricted use includes actions ranging from retaining Federal control and putting up fences to deed restrictions (prohibiting certain uses, e.g., agriculture or residential), deed notices (to alert all future owners of the presence of hazardous substances), or prohibiting use of wells.

EPA defines active control measures as "...all institutional controls and those engineering controls which control radiation dose or prevent exposure to members of the public, by methods other than physical removal" (EPA, 1995a). Zoning presumably qualifies as an active control. When planning active control measures, it is necessary to specify the entity that will implement the measures (usually a local government), that entity's responsibility to implement them, and assurances from the implementing agency that they will be implemented. EPA's draft regulation would require implementing entities to prepare a review every 5 years (EPA, 1995a, p. 83) until radionuclide concentrations are reduced so that standards for rural residential use are not exceeded. EPA's proposed standards are aimed at clean-up of sites to be released from federal control.

The principal radionuclides contaminating soil at the BNL site are Cs-137 (half-life 30 years) and $\mathrm{Sr}-90$ (half-life 28 years). Maintaining institutional control of the site for $50-100$ years would result in substantial natural decay. If a specific soil clean-up level ( $\mathrm{pCi} / \mathrm{g}$ ) were to be applied at a point 50-100 years in the future, effective current cleanup standards would be 3- to 8-fold higher than if they were effective today. This could substantially reduce the cost of clean-up with no increase in exposure to the public, provided access to contaminated areas is controlled in the intervening period. There are no plans to close BNL. Moreover, DOE could make a commitment to retain control of the site even if laboratory operations were shut down. In terms of meeting criteria for release of the site, this strategy could be decided entirely on a cost basis. While the laboratory remains in operation, there would be incremental costs for monitoring, and costs for maintaining institutional control would be small. Were the laboratory to be close at some point before site-release criteria were met, there would be additional costs for maintaining security of the site. DOE has already 
made this decision for OU IV - preliminary guidelines were derived assuming 50 years of institutional control (BNL, 1996).

As an example of how this issue is handled by other government agencies, Nuclear Regulatory Commission regulations (40 CFR 61.7) specify institutional control of access to a site for up to 100 years. The regulation states that "The government landowner administering the active institutional control program has flexibility in controlling site access which may include allowing productive uses of the land provided the integrity and long-term performance of the site are not affected".

In their regulations for remedial action at inactive uranium processing sites (40 CFR 192) USEPA suggests institutional controls such as providing an alternate source of drinking water and restricting inappropriate use of contaminated groundwater. The period of remediation may be extended up to 100 years to allow natural flushing of the groundwater rather than remedial action.

As a Superfund site regulated under CERCLA, soil clean-up is required without regard to the release of the site. There may be considerable opportunity, however, for negotiation with regulatory agencies on the timing of the application of cleanup standards. Given that access to contaminated sites is controlled, the key issue from the point of view of the regulatory agency is likely to be the potential impact on groundwater.

\section{If Institutional Control is Lost}

The institutional control that could be lost includes maintenance of land use restrictions and prohibition of private wells after release of the site. These controls are maintained by the local government. The BNL site is relatively small compared to other DOE sites and can easily be monitored. Moreover, state and local government and nongovernmental organizations take a special interest in the site because much of the site is in the core area if the pine barrens, a protected environment, and because the site also contains the headwaters of the Peconic River, a designated Scenic River. It is doubtful that institutional controls enforced by local governments would be seriously modified or breached at a site with such environmental and historic significance.

In their draft proposed radionuclide soil cleanup standards (EPA, 1995a), EPA proposed a backup in case institutional controls failed. This was $75 \mathrm{mrem} / \mathrm{y}$ in a resident farmer scenario. This would serve to keep public exposure within the $100 \mathrm{mrem} / \mathrm{y}$ limit of DOE Order 5400.5 and the recommendations of the ICRP and NCRP. EPA's proposal, however, was based on data from sites in more rural areas. There is no reasonable possibility that part of the BNL site would become a subsistence farm. The reasonable maximum $75 \mathrm{mrem} / \mathrm{y}$ backup scenario for establishing soil cleanup criteria is the suburban resident land use. The more restrictive of the suburban resident scenario at $75 \mathrm{mrem} / \mathrm{y}$ or the expected land use at $15 \mathrm{mrem} / \mathrm{y}$ should determine the cleanup criteria. 


\section{Alternative Scenarios for BNL}

Prevention of ecological damage is not the only reason for considering scenarios other than a resident farmer. A farming scenario may simply not be appropriate for the situation, or the costs to achieve clean-up guidelines sufficient to safely allow a resident farmer land use may be excessive. This section further discusses the rationale for alternative scenarios and describes some alternative scenarios for the BNL site.

\section{Rationalization for Different Scenarios}

Scenarios other than the Resident Farmer may be rationalized in two ways.

- Recognition of actual circumstances. For example, a site in the middle of a high density suburban area with quarter-acre lots is unlikely to have a future use of resident farmer. Consumption of home-grown vegetables may exist, but at a much lower level than in the Resident Farmer Scenario and there will be no home grown meat or poultry (which are generally prohibited in suburban communities).

- Land use restrictions. Land may be restricted because the community chooses a use other than residential or restrictions may be imposed because it is impractical or too costly to cleanup the site to a level suitable for residential or residential farmer use. For example, land that might otherwise be suitable for a residential farmer may be designated as an ecological park or open space.

The difference between the two is that greater surveillance may be necessary in the latter case to ensure that land uses incompatible with the exposure level do not appear in the future.

\section{Possible Alternative Scenarios}

There are an infinite number of possible scenarios, but many are simply slight variations of a type. The scenario should be characterized as specifically as is reasonable and the same type scenario may vary by location because of local circumstances. Type scenarios detailed below include suburban residential, industrial and commercial (treated together because they are similar) and three open space scenarios: an ecological reserve, undeveloped open space, and developed recreational space. Exposure pathways for the land use scenarios that may apply to BNL are summarized in Table 4-1. Note that although public water is expected to be available to future residential, commercial and recreational users of the site, the groundwater pathway was included at the insistence of the regulatory agencies. 
Table 4-1. Future land uses and exposure pathways for BNL.

\begin{tabular}{|l|l|l|l|l|}
\hline Pathway & $\begin{array}{l}\text { Industrial/ } \\
\text { Commercial }\end{array}$ & $\begin{array}{l}\text { Suburban } \\
\text { Residential }\end{array}$ & $\begin{array}{l}\text { Undeveloped } \\
\text { Open Space }\end{array}$ & $\begin{array}{l}\text { Developed } \\
\text { Recreational } \\
\text { Space }\end{array}$ \\
\hline External gamma exposure & Yes & Yes & Yes & Yes \\
\hline Inhalation of dust & Yes & Yes & Yes & Yes \\
\hline Inhalation of radon & Yes & Yes & Yes & Yes \\
\hline Ingestion of plant foods & No & Yes & Yes & No \\
\hline Ingestion of meat & No & No & Yes & No \\
\hline Ingestion of milk & No & No & No & No \\
\hline Ingestion of fish & No & No & No & No \\
\hline Ingestion of soil & Yes & Yes & Yes & Yes \\
\hline Ingestion of water & Yes & Yes & No & Yes \\
\hline
\end{tabular}

\section{Suburban Land Use}

Suburban development is characterized by single family homes on 1/4 to 2 acre lots. The family spends half of their time indoors at home. The Reasonable Maximum Exposure (RME) family is estimated to spend $25 \%$ of their time outdoors at home and $25 \%$ away from home (off the site). The assumption is made that exposure levels are higher outdoors than indoors due to greater exposure to direct radiation and respirable aerosols from contaminated soil. In some circumstances, however, it is possible that indoor radon levels could be high enough to shift this balance. The family is served by a public water supply. The RME family grows a vegetable garden and may have a few fruit trees.

Specific Application to BNL Site BNL is in a suburban area that is becoming more densely populated. The BNL Future Land Use Plan (BNL, 1995) designates part of the site for residential use. Suburban families do not grow grains, and the Long Island climate precludes growing citrus fruits. Connection with a public water supply would be required for a subdivision on the BNL site, or for individual homes near water mains (a situation that includes the areas on the site where residential use is planned). However, at the insistence of the regulatory agencies, it was assumed that a private well was used for drinking water. 


\section{Environmental Pathways}

- Ingestion. The ingestion pathway is through eating food grown in the home garden and direct ingestion of soil, especially by children. Ingestion in drinking water is also assumed.

- Inhalation. Exposure to contaminated air by airborne soil and radon. Indoor concentrations of radon vary by design and construction methods.

- External Exposure. Direct radiation from radionuclides in the soil. Industrial and Commercial Use

These are similar for exposure purposes since both involve workers who are on the site only during working hours or visitors or customers who are on the site for even shorter periods. There is little or no direct contact with soil because most activity is indoors and most soil is either paved over or covered with grass so even wind-blown dust is minimized. Industrial and commercial scenarios are parallel to "brown field" development, although for some DOE sites the development may be more suburban in character than the inner-city "brown field" concept.

Construction is possible in any land use that allows structures. The exposure duration is short but an analysis of the potential level of exposure should be done on a site-specific basis.

Specific Application to BNL Site Many current BNL activities are classed industrial or commercial and the post-closure scenario in the BNL Future Land Use Plan (BNL, 1995) suggests that the core developed area of the site might continue in commercial or industrial use. Since BNL is equipped with a treatment plant and a water distribution system, that plant may be continued or the distribution system may be hooked up to the SCWA. At the insistence of the regulatory agencies, however, it will be assumed that a private well will be used to provide drinking water.

Example The likely post-closure industrial use of the BNL site would be commercial office space and light industry, e.g., electronics or computer assembly.

\section{Environmental Pathways}

- Ingestion. The ingestion pathway is the possible exposure of grounds keeping staff and visiting children to contaminated soil. Drinking water will be from a private well and no food will be grown.

- Inhalation. Exposure to air contaminated by radon, and airborne soil will be limited to the workday (or to shorter periods for visitors and customers) and will generally be at lower levels than outdoor exposure levels. 
- External Exposures: Limited to direct radiation. Exposure time limited to workday and exposure level reduced from outdoor levels.

\section{Undeveloped Open Space Use}

Under this scenario, land would be released for public use with minimal control over access or activities. There would be no rest room facilities, no drinking water sources, and no developed recreational facilities, although walking trails would be likely. Activities would include walking, horseback riding and viewing wildlife. Dirt-bike riding could also occur. No permanent staff would be located on the site.

Specific Application to BNL Site This scenario would apply were the site turned over to state or local government and available funding for site development and maintenance was limited.

Example An example is the New York State owned Rocky Point Natural Resources Management Area property (located in Rocky Point, New York) in which walking trails were established and, while an easily available permit is required to enter, there are no fences and no permanent staff on site. Hunting is allowed and berries or mushrooms could be gathered. This land use would not include provision of drinking water.

\section{Environmental Pathways}

- Ingestion. Possible pathways include sediment and soil, primarily to young children. Mushrooms or other naturally occurring foods may be gathered, but most edible vegetation will not be present. Since hunting may be allowed, ingestion of game animals is a possible exposure pathway.

- Inhalation. Possible exposure is to air and suspended soil. Retrainment of soil into air is limited due to heavy vegetative cover.

- External Exposure. Possible pathway is direct exposure to radiation.

\section{Ecological Reserve}

This scenario is a modification of the undeveloped open space use scenario and includes the same exposure pathways. This would have limited or restricted access and exposures to soil contaminants would be smaller than for the undeveloped open space land use. This scenario is described below, but the suggested open space scenario for BNL is the undeveloped open space use described above. Exposure parameters for the ecological reserve scenario can be developed from values given in USDOE (1995c).

Public rest room facilities and drinking water may be provided, but the existence, treatment, and use of well water would be under government control. Staff may live on site, but location of staff housing could be determined based on the level of soil and groundwater contamination. Drinking water quality would be monitored. No developed recreational facilities would exist, with the possible 
exception of walking trails. Principal exposure possibilities would be to ecological workers on site. Public exposure would be through walking and wildlife viewing. The most extensive public exposure might be joggers who use trails daily.

Specific Application to BNL Site Since BNL is equipped with a treatment plant and a water distribution system, that plant may be continued or the distribution system may be hooked up to the SCWA. It will be assumed that any water provided will be from SCWA or will be treated to meet drinking water standards. Since residential housing is nearby, it is possible that a reasonable number of people might use the site on a regular basis for jogging or walking.

Example An example is the Federal Morton Wildlife Preserve located on Jessup Neck, Noyack, Long Island, New York. A ranger lives on site and maintains close, but not continual, control of visitors. Some areas are off-limits to protect wildlife. It is illegal to remove any vegetation from the site. While it is possible for visitors to gather berries, mushrooms, etc., it would be difficult for anyone to do so in large quantity.

\section{Environmental Pathways}

- Ingestion. Limited to sediment and soil, primarily to young children. Exposure time expected to be small. Controlled access and monitoring is expected to prevent ingestion of water, vegetation, or game by the reasonable maximal exposure (RME) individual.

- Inhalation. Exposure is to air and suspended soil. Exposure time is limited. Retrainment of soil into air is limited due to heavy vegetative cover.

- External Exposure. Possible pathway is exposure to direct radiation.

\section{Developed Recreational Space Use}

This includes ball fields, picnic areas, and playgrounds. Public rest room facilities and drinking water may be provided. Since this would be a public facility, if drinking water were provided it would be routinely monitored and meet drinking water standards. No permanent staff would be located on the site. This scenario would attract greater family use than other open space scenarios and thus would likely involve greater exposure to younger children. Exposure time is limited, but includes greater exposure to soil during active sporting activities.

Specific Application to BNL Site Since BNL is equipped with a treatment plant and a water distribution system, use of that plant may be continued or the distribution system may connected to the SCWA. However, at the insistence of the regulatory agencies, it will be assumed that any water provided will be from a private well. It is likely that only a small fraction of the site would be allocated to this land use.

Example. Typical municipal park with ball fields, picnic areas, playgrounds and possibly a swimming pool. 


\section{Environmental Pathways}

- Ingestion. Possible pathways include sediment and soil, primarily to young children. Most edible vegetation will not be present, and it would not be expected that any vegetation from the site would be consumed. Ingestion of drinking water was assumed.

- Inhalation. Possible exposure to air and suspended soil. The latter may involve exposures during active sports that are higher than typical outdoor exposures.

- External Exposure. Possible pathway is exposure to direct radiation.

\section{Criteria for Exposure Parameters for Alternative Scenarios}

EPA guidance provides that the exposures of the "reasonably maximally exposed (RME) individual" determine the cleanup requirements. It is not necessary to design the cleanup to protect an hypothetical maximally exposed individual, nor is it necessary to base the design on an extreme individual case. EPA (1989a) states that:

"The intent of the RME is to estimate a conservative exposure case (i.e., well above the average case) that is still within the range of possible exposures."

Setting the value of a parameter that contributes to the estimate of the RME usually involves professional judgment. This judgment should be documented by providing the full possible range of the parameter, the average or midpoint, the value used as the RME, and the rationale for selecting that value. An example from the Superfund Guidance (EPA, 1989a) is:

\begin{tabular}{|lcccc|}
\hline Variable & Range & Midpoint & Value Used & Rationale \\
$\begin{array}{l}\text { Exposure frequency } \\
\text { (d/wk) }\end{array}$ & $1-7$ & 3 & 5 & $\begin{array}{c}\text { Best professional } \\
\text { judgment }\end{array}$ \\
\hline
\end{tabular}

Significant subpopulations with exposure patterns due to the kind of activities in which they engage or the amount of time they may spend on the site must be evaluated in determining the RME individual. Age is one factor. Typical age breakdowns are child (1-6), youth (7-18), adult (19-55), senior adult (>56). Other examples are people working on the site compared to visitors or customers. RMEs are estimated by pathway. If a subpopulation is exposed by more than one pathway, EPA (1989a) indicates that "... the combination of exposures across pathways also must represent an RME." It may be necessary to consider trespassers or individuals involved in illegal acts (e.g., poaching game) if such individuals comprise a significant subgroup. Judgment can be used in determining whether a subpopulation should be evaluated. Further, the parameter values provided in EPA guidelines are to be regarded as general 
recommendations and can be changed based on site-specific information (EPA, 1989a, p. 6-5).

These guidelines are further interpreted in EPA's draft Radiation Site Cleanup Regulation (EPA, 1995a):

"Superfund's method for estimating RME for estimating chronic exposures on a site is to combine average concentrations of contaminants with reasonably conservative values for intake and duration of exposure. ... The RME estimate may include exposure from multiple sources and/or pathways, depending on whether an individual living on or near a site would be likely to experience such multiple exposures. Thus, the resulting exposure estimate was designed to be well above the average case, such that it would be protective of the majority of individuals at a site, but still within the range of possible exposures."

Soil cleanup criteria are based on a reasonable maximum exposure (RME). These are exposures to which real people might be exposed, but the number of people so exposed is likely to be few. The RME receptors proposed for BNL are summarized in Table 4-2.

For the purpose of evaluating net benefit (Section 7), it is more appropriate to use the average exposure. The average exposure times the number of people exposed provides the total population exposure, from which the total effect can be calculated. A set of average exposure receptors was. developed for each scenario (Table 4-2).

\section{Detailing the Scenarios}

BNL specific exposure factors (RME) for the alternative scenarios summarized above are given in Table 4-3 and documented in more detail in Appendicies I and II. Some key references are (EPA, 1989a; 1989b; 1991a; 1992a; Calabrese et al., 1989; USDOE, 1994; USDOE, 1995c). Exposure parameters for average exposure receptors are also given in the Appendices. Site specific hydrogeological parameters used in deriving generic cleanup guidelines for the BNL site are given in tables in Appendix I. 
Table 4-2. Receptors for the RME and average exposure cases for future land use scenarios at BNL.

\begin{tabular}{|l|l|l|}
\hline Scenario & \multicolumn{2}{|c|}{ Receptor } \\
\hline & \multicolumn{1}{|c|}{ RME } & \multicolumn{1}{c|}{ Average } \\
\hline Industrial/Commercial & worker in office complex & worker in office complex \\
\hline Suburban Residential & suburban resident & suburban resident \\
\hline Undeveloped Open Space & jogger & nature observer \\
\hline Developed Recreational Space & child-youth-adult & child-youth-adult \\
\hline
\end{tabular}

age adjusted (child-youth-adult, from birth to 30 years) 
Table 4-2. RESRAD Exposure Parameters for RME Analysis.

\begin{tabular}{|c|c|c|c|c|}
\hline$\longdiv { \text { RESRAD Parameters } }$ & $\begin{array}{l}\text { Commercial/ } \\
\text { Industrial }\end{array}$ & $\begin{array}{l}\text { Suburban } \\
\text { Residential }\end{array}$ & $\begin{array}{l}\text { Undeveloped } \\
\text { Open Space }\end{array}$ & $\begin{array}{l}\text { Developed } \\
\text { Recreational }\end{array}$ \\
\hline Exposure Duration (y) & 25 & 30 & 30 & 30 \\
\hline $\begin{array}{l}\text { Exposure Frequency (d/y) } \\
\text { (not used as input value) }\end{array}$ & 250 & 350 & 300 & 40 \\
\hline $\begin{array}{l}\text { Daily inhalation rate }\left(m^{3} / d\right) \\
\text { (not used as input value) }\end{array}$ & 20 & 20 & 118 & 57.8 \\
\hline $\begin{array}{l}\text { Annual inhalation rate } \\
\left(\mathrm{m}^{3} / \mathrm{y}\right)\end{array}$ & 7,300 & 7,300 & 20,000 & 20,000 \\
\hline $\begin{array}{l}\text { Daily drinking rate (Ld) } \\
\text { (not used as input value) }\end{array}$ & 1 & 2 & 0 & 1 \\
\hline Annual drinking rate $(\llcorner/ y)$ & 350 & 700 & 0 & 40 \\
\hline $\begin{array}{l}\text { Mass loading for inhalation } \\
\left(\mathrm{g} / \mathrm{m}^{3}\right)\end{array}$ & 0.0001 & 0.0001 & 0.0001 & 0.0002 \\
\hline $\begin{array}{l}\text { Fraction of time spent } \\
\text { indoors }\end{array}$ & 0.06 & 0.50 & 0 & 0 \\
\hline $\begin{array}{l}\text { Fraction of time spent } \\
\text { outdoors }\end{array}$ & 0.17 & 0.25 & 0.073 & 0.032 \\
\hline $\begin{array}{l}\text { Fruits, vegetables and grain } \\
\text { consumption }(\mathrm{kg} / \mathrm{y})\end{array}$ & 0 & 160 & 160 & 0 \\
\hline $\begin{array}{l}\text { Leafy vegetable } \\
\text { consumption }(\mathrm{kg} / \mathrm{y})\end{array}$ & 0 & 14 & 0 & 0 \\
\hline Meat ingestion rate $(\mathrm{kg} / \mathrm{y})$ & 0 & 0 & 63 & 0 \\
\hline Soil ingestion rate $(\mathrm{g} / \mathrm{y})$ & 36.5 & 43.8 & 36.5 & 65.7 \\
\hline $\begin{array}{l}\text { Livestock water fraction } \\
\text { contaminated }\end{array}$ & 0 & 0 & 0 & 0 \\
\hline $\begin{array}{l}\text { Contaminated fraction of } \\
\text { plants }\end{array}$ & 0 & 0.2 & 0.006 & 0 \\
\hline $\begin{array}{l}\text { Contaminated fraction of } \\
\text { meat }\end{array}$ & 0 & 0 & 0.14 & 0 \\
\hline $\begin{array}{l}\text { Livestock fodder intake for } \\
\text { meat }(\mathrm{kg} / \mathrm{d})\end{array}$ & 0 & 0 & 68 & 0 \\
\hline $\begin{array}{l}\text { Livestock water intake for } \\
\text { meat }(\sqcup d)\end{array}$ & 0 & 0 & 50 & 0 \\
\hline $\begin{array}{l}\text { Livestock intake for soil } \\
\text { (kg/d) }\end{array}$ & 0 & 0 & 0.5 & 0 \\
\hline $\begin{array}{l}\text { Mass loading for foliar } \\
\text { deposition }\left(\mathrm{g} / \mathrm{m}^{3}\right)\end{array}$ & 0 & 0.0001 & 0.0001 & 0.0001 \\
\hline
\end{tabular}




\section{DOSE LIMITS FOR DERIVING RESIDUAL RADIONUCLIDE CONCENTRATIONS IN SOIL}

\section{Introduction}

For most radioactively contaminated sites there are no regulations to guide cleanup of radionuclides in soils. EPA is working on a Radiation Site Cleanup Regulation for the release of Federally owned and regulated sites (40 CFR Part 196). The current draft of the proposed rule would require remediation to a committed effective dose of $15 \mathrm{mrem} / \mathrm{y}$ above background for a rural resident on a released site. Active controls (i.e. alternate land uses, institutional. controls, engineering controls) may be used to limit exposure to meet the standard. If active controls are used to meet the standard, exposure to a reasonably maximally exposed rural resident in the event that active controls fail must not exceed $75 \mathrm{mrem} / \mathrm{yr}$. The USDOE and USNRC should also be publishing final regulations for residual radioactive material in 1997.

New York State has a Technical Guideline of $10 \mathrm{mrem} / \mathrm{y}$ above background (NYS, 1993) that is not an formal ARAR (Applicable or Relevant and Appropriate Regulation) under Superfund for BNL but is a TBC Guideline (To Be Considered). Other cleanup standards or allowable doses to the public are used in various Federal regulations and USDOE Orders. Several recommendations have been published by independent groups such as the ICRP and NCRP.

This section develops the basis for an exposure limit for deriving BNL radionuclide soil guidelines by:

- Reviewing radiation protection philosophies and dose limits suggested by the international Commission on Radiological Protection (ICRP) and the National Council on Radiation Protection and Measurements (NCRP);

- Reviewing relevant dose limits required by DOE orders, federal guidelines and regulations;

- Reviewing the major problems associated with a dose limit of $15 \mathrm{mrem} / \mathrm{y}$ or less: variations in natural background, measurement problems and low cost-effectiveness;

- Identifying ARARS, dose and risk limits currently used by USDOE and other radioactively contaminated sites in deriving cleanup guidelines for radionuclides in soil; and

- Reviewing the logic used by EPA in its proposed regulation.

Based on this review, recommendations for dose limits for development of cleanup guidelines for radionuclides in soil at BNL are presented. 


\section{Dose and Risk}

USEPA usually uses cancer incidence in deriving standards for hazardous materials. The slope factor, a measure of cancer risk, currently used by USEPA is $6.7 \times 10^{-4}$ lifetime cancer incidence per rem.

The ICRP derived a value of $5 \times 10^{-4}$ deaths/rem for the probability of fatal cancer in a population after low dose, low dose rate irradiation. Risk estimates used in most regulatory actions and assessments prior to 1991 were slightly lower $\left(1 \times 10^{-4}\right.$ deaths/rem $)$ for low dose and low dose rate irradiation based on estimates given in ICRP (1977).

ICRP (1991) uses the term detriment to represent the combination of the probability of occurrence of an effect and a judgment of the severity of the effect. The principal components of detriment are: the probability of attributable fatal cancer, the weighted probability of attributable non-fatal cancer, the weighted probability of severe hereditary effects and the length of life lost if the harm occurs (ICRP, 1991). The value of this aggregated detriment at low dose for the general population is given as $7.3 \times 10^{-4} / \mathrm{rem}$.

The $15 \mathrm{mrem} / \mathrm{y}$ standard being considered by EPA is associated with a individual lifetime fatal cancer risk level of about $2.3 \times 10^{-4}$ (assuming a 30 year exposure and the ICRP risk factor for fatal cancer). Table 5-1 gives the individual lifetime fatal cancer risks, total detriment and cancer incidence (EPA risk factor) associated with a range of potential doses.

Table 5-1. Average individual lifetime risks for a range of potential dose rates using the ICRP ( $5 \times 10^{-4}$ deaths/rem; $7.3 \times 10^{-4}$ total detriment/rem $)$ and EPA (6.7 $\times 10^{-4}$ cancers/rem) risk factors.

\begin{tabular}{|c|c|c|c|c|c|c|}
\hline \multirow{4}{*}{$\begin{array}{c}\text { Dose } \\
\text { (mirem/y) }\end{array}$} & \multicolumn{6}{|c|}{ Individual Lifetime Risk } \\
\hline & \multicolumn{2}{|c|}{$\begin{array}{c}\text { ICRP Risk Factor } \\
\text { Fatal Cancer }\end{array}$} & \multicolumn{2}{|c|}{$\begin{array}{l}\text { ICRP Risk Factor } \\
\text { Total Detriment }\end{array}$} & \multicolumn{2}{|c|}{$\begin{array}{l}\text { EPA Risk Factor } \\
\text { Cancer Incidence }\end{array}$} \\
\hline & \multicolumn{2}{|c|}{ Exposure Period (years) } & \multicolumn{2}{|c|}{ Exposure Period (years) } & \multicolumn{2}{|c|}{ Exposure Period (years) } \\
\hline & 30 & 70 & 30 & 70 & 30 & 70 \\
\hline 1 & $1.5 \times 10^{-5}$ & $3.5 \times 10^{-5}$ & $2.2 \times 10^{-5}$ & $5.1 \times 10^{-5}$ & $2.0 \times 10^{-5}$ & $4.7 \times 10^{-5}$ \\
\hline 10 & $1.5 \times 10^{-4}$ & $3.5 \times 10^{-4}$ & $2.2 \times 10^{-4}$ & $5.1 \times 10^{-4}$ & $2.0 \times 10^{-4}$ & $4.7 \times 10^{-4}$ \\
\hline 15 & $2.3 \times 10^{-4}$ & $5.3 \times 10^{-4}$ & $3.3 \times 10^{-4}$ & $7.7 \times 10^{-4}$ & $3.0 \times 10^{-4}$ & $7.0 \times 10^{-4}$ \\
\hline 25 & $3.8 \times 10^{-4}$ & $8.8 \times 10^{-4}$ & $5.5 \times 10^{-4}$ & $1.3 \times 10^{-3}$ & $5.0 \times 10^{-4}$ & $1.2 \times 10^{-3}$ \\
\hline 75 & $1.1 \times 10^{-3}$ & $2.6 \times 10^{-3}$ & $1.6 \times 10^{-3}$ & $3.8 \times 10^{-4}$ & $1.5 \times 10^{-3}$ & $3.5 \times 10^{-3}$ \\
\hline 100 & $1.5 \times 10^{-3}$ & $3.5 \times 10^{-3}$ & $2.2 \times 10^{-3}$ & $5.1 \times 10^{-3}$ & $2.0 \times 10^{-3}$ & $4.7 \times 10^{-3}$ \\
\hline
\end{tabular}


Relevant ICRP and NCRP recommendations are often used as the basis for US regulations for radiation protection. Relevant ICRP and NCRP recommendations for exposures to the public are summarized in Table 5-2 and discussed below.

Table 5-2. ICRP and NCRP recommendations for exposures to the public.

\begin{tabular}{|l|l|}
\hline & \\
\hline ICRP (1991) & Practices: 100 mrem/y; ALARA assumed \\
\hline ICRP (1991) & $\begin{array}{l}\text { Intervention: no dose limit; should do more good than harm; } \\
\text { optimize net benefit }\end{array}$ \\
\hline NCRP (1994) & Practices: $100 \mathrm{mrem} / \mathrm{y}, 500 \mathrm{mrem} / \mathrm{y}$ for infrequent exposures \\
\hline NCRP (1994) & Practices: single source no greater than $25 \mathrm{mrem} / \mathrm{y}$ \\
\hline NCRP (1994) & Remedial action: natural sources excluding radon, $500 \mathrm{mrem} / \mathrm{y}$ \\
\hline
\end{tabular}

\section{ICRP Recommendations}

ICRP 60 (ICRP, 1991) is cited as the basis for most dose limits promulgated in the United States. ICRP 60 presents a framework of radiological protection as well as specific recommendations for the control of both public and occupational exposures. Use of the ICRP guidance should be based on the entire system of protection, not a single recommendation taken out of context. Careful interpretation and use of ICRP recommendations is important because they are heavily used by regulatory agencies in the United States as well as other countries and international non-governmental bodies.

ICRP 60 makes an explicit distinction between practices and intervention:

"Some human activities increase the overall exposure to radiation, either by introducing whole new blocks of sources, pathways and individuals, or by modifying the network of existing pathways from existing sources to man and thus increasing the exposure of individuals or the number of individuals exposed. The Commission calls these human activities "practices". Other human activities can decrease the overall exposure by influencing the existing form of the network. These activities may remove existing sources, modify pathways, or reduce the number of exposed individuals. The Commission describes all these activities as "intervention" (ICRP, 1991, p 27).

Routine practices at DOE facilities cause occupational and public exposure from routine operations. Environmental restoration comes under the definition of intervention, since it is an activity that may remove a radiation source or reduce contact of the public with a source.

The system for controlling exposure of the general public to radiation from practices is based on the following assumptions: the practice causing exposure 
should be adopted only if sufficient benefit is produced to offset any detriment; exposure should be kept as low as reasonably achievable, economic and social factors being taken into account; and exposures should be subject to dose limits.

ICRP 60 recommends a dose limit for public exposure of $1 \mathrm{mSv} / \mathrm{y}$ (100 $\mathrm{mrem} / \mathrm{y}$ ). This value was chosen based on an assessment of the risks associated with radiation exposure and the variation in exposure from natural background (average is approximately $100 \mathrm{mrem} / \mathrm{y}$, excluding radon).

The system for controlling exposure to the general public from radiation associated with an intervention is based on the following assumptions: the proposed intervention should do more good than harm; the form, scale and duration of the intervention should be chosen so that the net benefit should be as large as reasonably achievable; dose limits do not apply in the case of intervention; and there will be some level of projected dose above which, because of serious deterministic effects, intervention will almost always be justified.

\section{NCRP Recommendations}

NCRP (1994) recommends a dose limit to the general public for exposures to man-made sources other than medical and natural background of $100 \mathrm{mrem} / \mathrm{yr}$. NCRP also recommends that no single source or set of sources under one control should result in an individual being exposed to more than 25 $\mathrm{mrem} / \mathrm{yr}$.

NCRP does not make the strong distinction between practice and intervention made in ICRP (1991), but does provide alternate limits for remedial action for radon and other naturally occurring radionuclides. NCRP (1994) recommends that remedial action be undertaken when continuous exposures from natural sources (excluding radon) exceed $500 \mathrm{mrem} / \mathrm{yr}$.

\section{ALARA}

ALARA (As Low as Reasonably Achievable) is part of the system of radiation protection suggested by ICRP and NCRP and adopted by DOE, EPA and NRC.

ALARA is a process for reducing exposures to radiation taking into account the societal, environmental, technological, economic and practical and public policy considerations to make a judgment concerning the optimum level of public health protection. ALARA refers to reducing exposures to reasonably achievable levels after a dose limit has been met.

DOE has guidance for implementation of ALARA Requirements (USDOE, 1991): "As Low As is Reasonably Achievable" (ALARA) is a phrase used to describe an approach to radiation protection by which exposures (both individual and collective to the work force and the general public) and releases of radioactive material to the environment are managed and controlled to levels as low as is reasonably achievable below applicable dose limits. The objective of 
the ALARA process is not the attainment of a particular dose level, but rather the attainment of the lowest practicable dose level after taking into account social, technical, economic, practical and public policy considerations" (USDOE, 1991). The ALARA process, as it relates to soil cleanup criteria, is described in more detail in Section 7.

\section{Current Regulations, Guidance and USDOE Orders}

Relevant current and proposed regulations are listed in Table 5-3. Table 5-4 summarizes guidelines from New York State and USEPA and DOE Orders. Some of these regulations and guidelines may be evaluated in terms of their potential applicability as ARARS and TBCs for BNL, while others were used by EPA in justifying the $15 \mathrm{mrem} / \mathrm{y}$ proposed standard. These regulations, guidelines and orders are summarized below.

\section{Current and Proposed Regulations}

\section{NCP/CERCLA}

The National Oil and Hazardous Substance Pollution Contingency Plan (NCP) requires that remedies at Superfund sites meet two threshold criteria: compliance with ARARS (Applicable or Relevant and Appropriate Requirements) and overall protection of human health and the environment. Federal and state regulations are ARARS, and other guidelines are treated as "to be considered". When ARARS are not available, the NCP states that:

"the primary guidelines for Superfund cleanups are to be protective of public health and the environment and to comply with ARARS. When ARARS are not available, Superfund develops a reasonable maximum exposure scenario that describes the current and potential risk posed by the site in order to determine what is necessary to achieve protection against such risks to human health. Based on this scenario, Superfund selects remedies that reduce the risks from carcinogenic contaminants at such a site such that the excess risk from any medium to an individual exposed over a lifetime generally falls within the range from $10^{-4}$ to $10^{-6}$." (preamble to NCP, Federal Register 8686, March 8, 1990). 
Table 5-3. Current and proposed regulations.

\begin{tabular}{|c|c|}
\hline USEPA & \\
\hline CERCLANCP (NCP 40 CFR 300) & $\begin{array}{l}\text { No defined radiation standards, requires lead agency to } \\
\text { identify ARARS. When ARARS are not available remedies } \\
\text { should be selected that generally fall within the lifetime } \\
\text { cancer risk range of } 10^{-4} \text { to } 10^{-6} \text {. }\end{array}$ \\
\hline $\begin{array}{l}\text { Proposed Radiation Site Cleanup } \\
\text { Standard (40 CFR Part 196) }\end{array}$ & $\begin{array}{l}\text { For release of sites; } 15 \text { mrem/y above background; } 75 \\
\text { mrem/y if controls fail. Groundwater MCLs must be met } \\
\text { unless impracticable. }\end{array}$ \\
\hline $\begin{array}{l}\text { Proposed Federal Radiation } \\
\text { Protection Guidance for Exposure of } \\
\text { the General Public (59 FR 66414), }\end{array}$ & $\begin{array}{l}100 \mathrm{mrem} / \mathrm{y} \text { from all sources except background, accidents, } \\
\text { occupational exposures and medical practices. }\end{array}$ \\
\hline $\begin{array}{l}\text { Uranium Mill Tailings Radiation } \\
\text { Control Act (UMTRCA) } 40 \text { CFR Part } \\
192 .\end{array}$ & $\begin{array}{l}\text { Applies to active and inactive uranium mill tailings sites. } \\
\text { Radium in soil: } 5 \mathrm{pCi} / \mathrm{g} \text { above background, indoor radon } \\
0.02 \mathrm{WL} \text { annual average, } 0.03 \mathrm{WL} \text { maximum, and } 20 \mu \mathrm{R} / \mathrm{hr} \text {. }\end{array}$ \\
\hline $\begin{array}{l}\text { High Level Waste Rule (40 CFR Part } \\
\text { 191; December 20, 1993, } 58 \text { FR } \\
\text { 66402). }\end{array}$ & $\begin{array}{l}\text { Environmental Radiation Protection Standards For } \\
\text { Management And Disposal of Spent Nuclear Fuel, High } \\
\text { Level and Transuranic Radioactive wastes. } 15 \mathrm{mrem} / \mathrm{y} \text { for } \\
\text { all pathways. }\end{array}$ \\
\hline $\begin{array}{l}\text { National Emission Standards for } \\
\text { Hazardous Air Pollutants: Standards } \\
\text { for Radionuclides (NESHAPS, } 40 \\
\text { CFR 61) }\end{array}$ & $\begin{array}{l}\text { Standards for radionuclide emissions to air; } 10 \mathrm{mrem} / \mathrm{yr} \text {. } \\
\mathrm{Rn}-222 \text { emission rate limited to } 20 \mathrm{pCi} / \mathrm{m}^{2} \mathrm{sec} \text { from disposal } \\
\text { of material contaminated with radium. }\end{array}$ \\
\hline $\begin{array}{l}\text { Current and Proposed National } \\
\text { Primary Drinking Water Regulations } \\
\text { (40 CFR 141) }\end{array}$ & $\begin{array}{l}\text { Safe Drinking Water Act Maximum Contaminant Levels for } \\
\text { radionuclides in drinking water. Gross alpha emitters: } 15 \\
\text { pCi/L; Gross beta and gamma emitters: } 4 \text { mrem/yr. Current } \\
\text { standard for }{ }^{226} \mathrm{Ra}+{ }^{228} \mathrm{Ra} \text { is } 5 \mathrm{pCi} / \mathrm{L} \text {. Proposed standard } \\
\text { for }{ }^{226} \mathrm{Ra},{ }^{228} \mathrm{Ra} \text { is } 20 \mathrm{pCi} / \mathrm{L} ; \mathrm{U} \text { is } 30 \mathrm{pCi} / \mathrm{L} \text {. }\end{array}$ \\
\hline $\begin{array}{l}\text { Environmental Radiation Protection } \\
\text { Standards for Nuclear Power } \\
\text { Operations ( } 40 \text { CFR Part 190) }\end{array}$ & $\begin{array}{l}\text { Applies to facilities in the uranium fuel cycle: } 25 \mathrm{mrem} / \mathrm{y} \\
\text { whole body; } 75 \mathrm{mrem} / \mathrm{y} \text { to the thyroid and other organs. }\end{array}$ \\
\hline \multicolumn{2}{|l|}{ USDOE } \\
\hline $\begin{array}{l}\text { Proposed Radiation Protection of the } \\
\text { Public and the Environment (58 FR } \\
\text { 16268, 10 CFR Part 834) }\end{array}$ & $\begin{array}{l}\text { Primary limit for the public, all sources: } 100 \mathrm{mrem} / \mathrm{y} \text {. } \\
\text { Contractor derives authorized limits for soil guidelines. } \\
\text { ALARA process required. }\end{array}$ \\
\hline \multicolumn{2}{|l|}{ NRC } \\
\hline $\begin{array}{l}\text { Licensing Requirements for Land } \\
\text { Disposal of Radioactive Waste (10 } \\
\text { CFR 61) }\end{array}$ & $\begin{array}{l}\text { Performance objectives, criteria, terms and conditions for } \\
\text { disposal of radioactive waste. Annual dose limit: equivalent } \\
\text { of } 25 \text { mrem to the whole body, } 75 \text { mrem to the thyroid, and } \\
25 \text { mrem to any other organ of any member of the public. }\end{array}$ \\
\hline $\begin{array}{l}\text { Standards for Protection Against } \\
\text { Radiation (10 CFR 20) and Proposed } \\
\text { revision to include decontamination } \\
\text { and decommissioning criteria }\end{array}$ & $\begin{array}{l}\text { Exposures for NRC licensed operations: current standard is } \\
100 \mathrm{mrem} / \mathrm{y} \text { plus ALARA; proposed revision is } 15 \mathrm{mrem} / \mathrm{y} \\
\text { plus ALARA. }\end{array}$ \\
\hline
\end{tabular}


Table 5-4. Guidelines and DOE Orders.

\begin{tabular}{|c|c|}
\hline New York State & \\
\hline $\begin{array}{l}\text { Cleanup Guideline for Soils } \\
\text { Contaminated with Radioactive } \\
\text { Materials, NYS TAGM 4003, } 1993\end{array}$ & $10 \mathrm{mrem} / \mathrm{y}$ above background plus ALARA. \\
\hline \multicolumn{2}{|l|}{ USDOE } \\
\hline DOE Order 5400.5 & $\begin{array}{l}100 \mathrm{mrem} / \mathrm{y} \text { from all sources except background, } \\
\text { occupational and medical practices, plus ALARA. } \\
{ }^{226} \mathrm{Ra}+{ }^{228} \mathrm{Ra} \text { less than } 5 \mathrm{pCi} / \mathrm{g} \text {. }\end{array}$ \\
\hline \multicolumn{2}{|l|}{ USEPA } \\
\hline Radon Action Level (EPA, 1993a) & $\begin{array}{l}\text { USEPA recommends mitigation measures for homes } \\
\text { above } 4 \mathrm{pCi} / \mathrm{L} \text { radon; suggests consider mitigation above } \\
2 \mathrm{pCi} / \mathrm{L} \text {; risk from } 4 \mathrm{pCi} / \mathrm{L} \text { is } 1.3 \times 10^{-2} \text {. }\end{array}$ \\
\hline \multicolumn{2}{|l|}{ NRC } \\
\hline $\begin{array}{l}\text { Termination of Operating Licenses for } \\
\text { Nuclear Reactors NRC Regulatory } \\
\text { Guide } 1.86\end{array}$ & $\begin{array}{l}\text { Procedure for terminating an operating license for a } \\
\text { nuclear power reactor. Beta-gamma emitters have limits } \\
\text { of } 5,000 \mathrm{dpm} / 100 \mathrm{~cm}^{2} \text { average }, 15,000 \mathrm{dpm} / 100 \mathrm{~cm}^{2} \\
\text { maximum and } 1,000 \mathrm{dpm} / 100 \mathrm{~cm}^{2} \text { removable. For } \\
\text { transuranics and radium-226 the limits are } 100 \mathrm{dpm} / 100 \\
\mathrm{~cm}^{2} \text { average, } 300 \mathrm{dpm} / 100 \mathrm{~cm}^{2} \text { maximum and } 20 \\
\mathrm{dpm} / 100 \mathrm{~cm}^{2} \text { removable. }\end{array}$ \\
\hline
\end{tabular}

EPA guidance also states that the $10^{-4}$ value is not a strict upper limit (EPA, 1991):

"EPA uses the general $10^{-4}$ to $10^{-6}$ risk range as a "target range" within which the Agency strives to manage risks as part of a Superfund cleanup. Once a decision has been made to take an action, the Agency has expressed a preference for cleanups achieving the more protective end of the range (i.e., $10^{-6}$ ), although waste management strategies achieving reductions in site risks anywhere within the risk range may be deemed acceptable by the EPA risk manager. Furthermore, the upper boundary of the risk range is not a discrete line at $1 \times 10^{-4}$, although EPA generally uses $1 \times 10^{-4}$ in making risk management decisions. A specific risk estimate around $10^{-4}$ may be considered acceptable if justified based on site-specific conditions, including any remaining uncertainties on the nature and extent of contamination and associated risks. Therefore, in certain cases EPA may consider risk estimates slightly greater than $1 \times 10^{-4}$ to be protective".

Proposed Radiation Site Cleanup Standard (40 CFR Part 196)

USEPA is working on a Radiation Site Cleanup Regulation for the release of Federally owned sites. The current draft requires remediation be conducted to achieve a committed effective dose of $15 \mathrm{mrem} / \mathrm{y}$ above background for a reasonably maximally exposed rural resident on a released site (EPA, 1995a). Active controls (i.e. alternate land uses, institutional controls, engineering 
controls) may be used to limit exposure to meet the standard. If active controls are used to meet the standard, exposure to a reasonably maximally exposed rural resident in the event that active controls fail must not exceed $75 \mathrm{mrem} / \mathrm{yr}$. The proposed regulation also requires that maximum contaminant levels (MCLs) in drinking water be met unless technically impracticable. Active institutional controls can then be used to prevent exposure from the drinking water pathway. When active controls are used to meet the $15 \mathrm{mrem} / \mathrm{y}$ dose limit, the site must be re-evaluated every 5 years.

Proposed Federal Radiation Protection Guidance for Exposure of the General Public (59 FR 66414)

EPA is proposing radiation protection guidance for federal agencies that are involved with protection of the public from radiation. The new guidance is recommending a five fold reduction of the maximum allowable dose to a member of the public. This proposed guidance would require all federal agencies to adopt an effective dose equivalent limit to the public of $100 \mathrm{mrem} / \mathrm{yr}$. There are eight specific recommendations that address topics such as: 1) justification of exposure, 2) keeping public exposures as low as reasonably achievable, 3) a $100 \mathrm{mrem} / \mathrm{y}$ effective dose equivalent, 4) establishment of source term constraints, 5) federal agency's actions to consider risk impacts, 6) radiation record appropriate for risk level, 7) uniform dose conversion factors, and 8) use of decision-making tools to determine if agency imposed actions to ensure specific source or categories of sources are designed and operated correctly are reasonable.

\section{Uranium Mill Tailings Radiation Control Act (UMTRCA) 40 CFR Part 192}

40 CFR 192 addresses the remediation of active and inactive mill tailings sites. Subpart $B$ addresses residual radioactivity at vicinity properties and Subpart $C$ addresses supplemental standards.

Subpart $B$ requires that: radium in soils be reduced to $5 \mathrm{pCi} / \mathrm{g}$ above background levels; indoor radon be controlled to an annual average of $0.02 \mathrm{WL}$; maximum $0.03 \mathrm{WL}$ and external exposure must be controlled to $20 \mu \mathrm{R} / \mathrm{hr}$ above background. These limits are associated with an excess cancer risk of approximately $10^{-3}$, although the $5 \mathrm{pCi} / \mathrm{g}$ standard was chosen for technical feasibility rather than health reasons.

The supplemental standards in Subpart $\mathrm{C}$ provide a waiver from Subpart $B$ requirements if specific criteria involving costs, benefits and risks are met. Supplemental standards are permitted where application of the Subpart B requirements would: (1) pose a clear and present risk of injury to workers or the public notwithstanding reasonable measures to limit damage; 2 ) directly produce environmental harm that is clearly excessive compared to health benefits; and 3) result in an estimated cost of remedial action that is unreasonably high relative to the long-term benefits, and the residual radioactive materials do not pose a clear present or future hazard; or result in an unreasonably high cost of cleaning up a building relative to its benefits. 
High Level Waste Rule (40 CFR Part 191: December 20, 1993, 58 FR 66402)

Environmental radiation protection standards for management and disposal of spent nuclear fuel, high level and transuranic radioactive wastes. sets a dose standard of $15 \mathrm{mrem} / \mathrm{yr}$. These standards are designed to protect public health and the environment from the disposal of high level waste for 10,000 years. Groundwater concentrations resulting from the disposal system should not exceed the EPA drinking water standards for 1,000 years after disposal. In addition, specific release limits over the 10,000 year disposal period are prescribed for long-lived isotopes.

National Emission Standards for Hazardous Air Pollutants: Standards for Radionuclides, NESHAPS (40 CFR 61)

Standards for radionuclide emissions require that doses from radionuclide air emissions not exceed $10 \mathrm{mrem} / \mathrm{y}$ effective dose equivalent. Contributions from the ground water pathway are excluded. The regulations were developed under the Clean Air Act primarily for routine emissions from facilities that handle, use or produce radioactive materials as part of facility operations. A specific standard was established for emissions from radium disposal: maximum emission rate of $20 \mathrm{pCi} / \mathrm{m}^{2}$ sec for ${ }^{222} \mathrm{Rn}$.

National Primary Drinking Water Regulations, Current and Proposed (40 CFR 141)

Under the Safe Drinking Water Act, USEPA set Maximum Contaminant Levels (MCLs) for radionuclides. Modifications to these standards have been proposed. The original and proposed regulations set exposure from gross alpha emitters to $15 \mathrm{pCi} / \mathrm{L}$ and the concentration of manmade beta/gamma emitting radionuclides to concentrations that could result in an exposure of $4 \mathrm{mrem} / \mathrm{y}$ to the whole body or any organ. The current standard for ${ }^{226} \mathrm{Ra}+{ }^{228} \mathrm{Ra}$ is $5 \mathrm{pCi} / \mathrm{L}$. The proposed standard for ${ }^{226} \mathrm{Ra}$ and ${ }^{228} \mathrm{Ra}$ is $20 \mathrm{pCi} / \mathrm{L}$ and the proposed standard for uranium is $30 \mathrm{pCi} / \mathrm{L}$. The regulation applies to community water supplies serving greater than 25 persons or 15 connections.

Environmental Radiation Protection Standards for Nuclear Power Operations (40 CFR Part 190, 42 FR 2858).

These standards are for protection of the public from activities associated with the uranium fuel cycle and were promulgated in 1977. The standards require that the annual dose not exceed 25 mrem to the whole body, 75 mrem to the thyroid and 25 mrem to any other organ. These dose limits were based on an earlier system of dose calculation. EPA says these values using the current system are comparable to a committed effective dose of $15 \mathrm{mrem} / \mathrm{y}$ (EPA, 1995a). 
Proposed Radiation Protection of the Public and the Environment (58 FR 16268, 10 CFR Part 834)

The Department of Energy is promulgating a regulation for the protection of the public and the environment against ionizing radiation. This new rule codifies the requirements contained in DOE Order 5400.5 which provides guidance on the same subject. This rule cover four major areas relating to radiation protection of the public and environment: 1) public dose limits and ALARA; 2) radioactive effluent release management; 3) requirements for decommissioning; surveys, release of buildings, land, equipment and personnel containing radioactive material; and waste storage; and 4) effluent monitoring and environmental surveillance programs. Item 3 for release of land with residual radioactive materials, contains the requirements for soil remediation guidelines. DOE will approve case specific authorized and supplemental limits as requested by each applicant. The information that is needed by DOE in each application is defined in the rule. These authorized limits will meet the regulatory limits specified in 10 CFR Part 834 and will be derived in accordance with the ALARA process requirements, documented, and approved by the DOE and be made part of the public record. Section 834.302 discusses soil residual radioactive material. It requires that the authorized and supplemental limits for all radionuclides in soil be derived using approved environmental pathway/ dose assessment models. The primary limit for exposure of the public is $100 \mathrm{mrem} / \mathrm{y}$ from all sources.

\section{Standards for Protection Against Radiation Current and Proposed (10 CFR 20)}

These NRC standards are designed to limit exposure to radiation from NRC licensed operations. The standards were revised in 1991 to include a nonoccupational exposure limit of $100 \mathrm{mrem} / \mathrm{y}$ from all sources excluding background, and ALARA is required. The proposed revision is $15 \mathrm{mrem} / \mathrm{y}$ for radionuclides that are distinguishable from background. For sites that employ institutional controls, there should be reasonable assurance that if controls fail the total effective dose equivalent would not exceed $100 \mathrm{mrem} / \mathrm{yr}$. Groundwater concentrations must meet EPA standards for 1,000 years.

Licensing Requirements for Land Disposal of Radioactive Waste (10 CFR 60)

These NRC standards establish the performance objectives, criteria and terms and conditions that apply to the issuing of licenses for the land disposal of radioactive waste. The regulations apply to a new land disposal facility licensed by NRC, and to existing low-level waste disposal sites at license renewal (EPA, 1993b). The performance objectives for land disposal of low level radioactive waste require that "concentrations of radioactive material which may be released to the general environment in groundwater, surface water, air, soil, plants or animals must not result in an annual dose exceeding an equivalent of $25 \mathrm{mrem}$ to the whole body, 75 mrem to the thyroid and 25 mrem to any other organ of any member of the public". 


\section{Guidelines and USDOE Orders}

New York State Guidelines

New York State has a cleanup guideline for soils contaminated with radioactive materials of $10 \mathrm{mrem} / \mathrm{y}$ above background concentrations with application of ALARA (NYS, 1993). This guideline is in the form of a Technical Administrative Guidance Memorandum (TAGM) and refers primarily to release for unrestricted use: "The estimated dose limit of $10 \mathrm{mrem} / \mathrm{y}$ refers to land released for unrestricted use" (NYS, 1993).

The guideline explicitly allows consideration of institutional controls to reduce exposure: "If unrestricted use scenario calculations result in dose estimates that are greater than $10 \mathrm{mrem} / \mathrm{y}$, it may be necessary to invoke institutional controls and/or deed restrictions so that actual doses from allowed uses are not likely to exceed $10 \mathrm{mrem} / \mathrm{y}^{\prime \prime}(\mathrm{NYS}, 1993)$.

The guideline also mentions alternative procedures and the need for evaluation of remedial options on a case by case basis when:

"(1) the health or safety of individuals involved in a cleanup may necessitate acceptance of a dose greater than $10 \mathrm{mrem} / \mathrm{y}$ to the maximally exposed individual, or

(2) the cleanup may cause irreversible destruction or loss of environmental habitat" (NYS, 1993).

DOE Order 5400.5 (Radiation Protection of the Public and the Environment).

This DOE Order states that doses received by the general public from all sources of radiation exposure at a DOE facility must not exceed an effective dose equivalent of $100 \mathrm{mrem} / \mathrm{y}$, and that all releases of radioactive material must be "as low as reasonably achievable" (ALARA). Generic guidelines for residual concentrations of ${ }^{226} \mathrm{Ra},{ }^{228} \mathrm{Ra},{ }^{230} \mathrm{Th}$ and ${ }^{222} \mathrm{Th}$ are $5 \mathrm{pCi} / \mathrm{g}$ averaged over the first $15 \mathrm{~cm}$ of soil and $15 \mathrm{pCi} / \mathrm{g}$ below $15 \mathrm{~cm}$.

\section{Radon Action Level}

USEPA has recommended an action level for radon of $4 \mathrm{pCi} / \mathrm{L}$. Above this level USEPA recommends the application of mitigation measures (EPA, 1993a). EPA advises homeowners to consider mitigating homes that have radon levels above $2 \mathrm{pCi} / \mathrm{L}$. The action level of $4 \mathrm{pCi} / \mathrm{L}$ corresponds to a lifetime cancer risk of $1.3 \times 10^{-2}$.

Termination of Operating Licenses for Nuclear Reactors NRC Regulatory Guide 1.86

This guide describes a method and procedure for terminating an operating license for a nuclear power reactor. The guide discusses how to transfer an operating license to a by product material license, surveillance and security requirements, decontamination for release to unrestricted areas and the procedure for retiring a reactor and it's system components. This guide contains 
a table that lists acceptable surface contamination levels. Beta-gamma emitters have limits of $5,000 \mathrm{dpm} / 100 \mathrm{~cm}^{2}$ average, $15,000 \mathrm{dpm} / 100 \mathrm{~cm}^{2}$ maximum and $1,000 \mathrm{dpm} / 100 \mathrm{~cm}^{2}$ removable. For transuranics and radium-226 the limits are $100 \mathrm{dpm} / 100 \mathrm{~cm}^{2}$ average, $300 \mathrm{dpm} / 100 \mathrm{~cm}^{2}$ maximum and $20 \mathrm{dpm} / 100 \mathrm{~cm}^{2}$ removable.

\section{Major Issues}

This section explores the major problems associated with the 10 and 15 $\mathrm{mrem} / \mathrm{y}$ dose limits. These issues include the large range of background exposures from soil relative to a 10 or $15 \mathrm{mrem} / \mathrm{y}$ limit, problems with measurement at this level, and issues associated with cost-effectiveness and risk reduction.

\section{Background}

Estimates of average doses from background radiation are summarized in Table 5-5. The average total dose in the US is about $300 \mathrm{mrem} / \mathrm{yr}$. The total effective dose from natural sources in the US excluding radon varies from about 65 to $125 \mathrm{mrem} / \mathrm{y}$ with an average of about $100 \mathrm{mrem} / \mathrm{y}$ (NCRP, 1993).

Table 5-5. Background doses in the United States and at BNL (NCRP, 1993; Naidu and Royce, 1994).

\begin{tabular}{|c|l|}
\hline $300 \mathrm{mrem} / \mathrm{y}$ & average total background \\
\hline $200 \mathrm{mrem} / \mathrm{y}$ & radon and radon daughters \\
\hline $100 \mathrm{mrem} / \mathrm{y}$ & background excluding radon \\
\hline $27 \mathrm{mrem} / \mathrm{y}$ & cosmic radiation component of background \\
\hline $28 \mathrm{mrem} / \mathrm{y}$ & terrestrial radiation component of background \\
\hline $40 \mathrm{mrem} / \mathrm{y}$ & body burden component of background \\
\hline $0.4 \mathrm{mrem} / \mathrm{y}$ & nuclear fuel cycle component of background \\
\hline $1.1 \mathrm{mrem} / \mathrm{y}$ & fallout component of background \\
\hline $64 \mathrm{mrem} / \mathrm{y}$ & $\begin{array}{l}\text { terrestrial and cosmic radiation background near BNL (TLD } \\
\text { measurements; 1993) }\end{array}$ \\
\hline $1 \mathrm{mrem} / \mathrm{y}$ & BNL operations \\
\hline
\end{tabular}

The dose from natural background excluding radon is made up of exposures from cosmic radiation $(27 \mathrm{mrem} / \mathrm{y})$, terrestrial radiation $(28 \mathrm{mrem} / \mathrm{y})$, radionuclides in the body $(40 \mathrm{mrem} / \mathrm{y})$, the nuclear fuel cycle $(0.4 \mathrm{mrem} / \mathrm{y})$ and fallout (1.1 mrem/y) (NCRP, 1993). The primary determinant of outdoor adsorbed dose in air from terrestrial radiation is the soil concentration of naturally occurring radionuclides. Naturally occurring Potassium-40 is the biggest contributor to the dose from terrestrial radiation. 
Background exposures fluctuate due to seasonal cycles and variation in cosmic radiation. The variation in exposure to cosmic radiation is about $10 \%$ over the 11 year solar cycle. Doses from exposure to background radiation also vary spatially. The dose from cosmic radiation is a function of latitude and altitude.

Local variations in terrestrial background radiation can also be dramatic. Significant fluctuations in the terrestrial gamma dose measured using Thermoluminescent dosimeters (TLDs) at the Shoreham nuclear facility site on Long Island, New York were documented by dePlanque (1995). The site had an annual average terrestrial gamma dose of about $35 \mathrm{mrem} / \mathrm{y}$, and levels varied by more than $50 \%$ over a distance of 1 mile from the site boundary.

TLDs are used in the Environmental Monitoring program at BNL. TLDs located offsite and within 11 miles of the laboratory suggest a dose from gamma radiation of about $60 \mathrm{mrem} / \mathrm{y}$ (Naidu and Royce, 1994). The average value for 1993 was $63.5 \mathrm{mrem} / \mathrm{y}$ with a range of 48.5 to $75.9 \mathrm{mrem} / \mathrm{y}(25 \mathrm{mrem} / \mathrm{y}$ range; Naidu and Royce, 1994). This dose includes both the cosmic and terrestrial component of background exposures near the laboratory.

Because of the large variation in background exposure across the United States and even within a single site, it will be difficult to document background levels at a specific site. Because of uncertainty in background levels, there can be difficulty in determining compliance with low dose limits.

\section{Measurement of Background Levels}

Radionuclide concentrations (and the associated dose) that can be measured vary depending on the radionuclide and on measurement technique and equipment. For some radionuclides, it is difficult to distinguish the siterelated levels from the background level.

USEPA considered minimum detectable concentrations (MDCs), background levels, and DOE analytical laboratory guidelines, and found that 14 radionuclides may be difficult to detect in soil at a concentration that corresponds to $15 \mathrm{mrem} / \mathrm{y}$ under a rural residential exposure scenario (EPA, 1995a). Table 5-6 lists these radionuclides and the reason they may be difficult to detect. Those radionuclides that are of interest at BNL include Cs-137, K-40, Ra-226, Ra-228, Sr-90, Th-230, Th-232, I-129, C-14 and Th-228. In most cases special analytical methods will be required to obtain the needed sensitivities for these isotopes. 
Table 5-6. Radionuclides that may be difficult to detect in soil at $15 \mathrm{mrem} / \mathrm{y}$ above background (EPA, 1995a; shaded radionuclides have been detected in soil at BNL).

\begin{tabular}{|c|c|}
\hline RADIONUCLIDE & REASON FOR DIFFICULTY \\
\hline 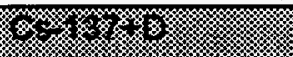 & background \\
\hline 8 & background \\
\hline $\mathrm{Pa-231}$ & background \\
\hline 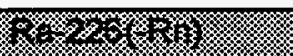 & background \\
\hline Ra-228+D & background \\
\hline 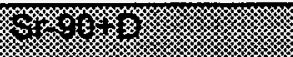 & background \\
\hline 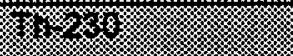 & background \\
\hline 湫 & background \\
\hline $\mathrm{Cl}-36$ & minimum detectable concentrations \\
\hline (4) & minimum detectable concentrations \\
\hline 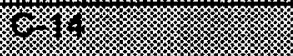 & background + minimum detectable concentrations \\
\hline 40 & background + minimum detectable concentrations \\
\hline ren & background + minimum detectable concentrations \\
\hline 极 & background + minimum detectable concentrations \\
\hline
\end{tabular}

$D=$ decay products

\section{Cost-effectiveness}

Cleanup to low exposure rates from soil is not very cost-effective in terms of the number of deaths averted. In EPA's proposed Radiation Site Cleanup Standard (October 21, 1993; 58 FR 54474), the agency calculated the cost per death averted by remediating soils for all Federally owned sites with radionuclide soil contamination (Table 5-7). Very few cancer deaths were averted, and the costs were high even for cleanup from the EPA baseline assumption of 100 $\mathrm{mrem} / \mathrm{y}$ to $75 \mathrm{mrem} / \mathrm{yr}$. Cleanup to $15 \mathrm{mrem} / \mathrm{y}$ was not at all cost effective (incremental costs from 25 to $15 \mathrm{mrem} / \mathrm{y} ; \$ 1000$ million/life saved). An average value currently used by Federal agencies is the U.S. is $\$ 2.1$ million/life saved (Baum, 1994). Values less than $15 \mathrm{mrem} / \mathrm{y}$ resulted in additional deaths from exposure to remediation workers. Ecological risks, liabilities and property values were not considered in this analysis. 
Table 5-7. Incremental cancer deaths averted and costs per death averted (abstracted and calculated from EPA, 1995a).

\begin{tabular}{|l|l|l|l|}
\hline $\begin{array}{l}\text { Change Standard } \\
\text { From: }\end{array}$ & $\begin{array}{l}\text { Incremental } \\
\text { Deaths Averted }\end{array}$ & $\begin{array}{l}\text { Incremental Costs } \\
\text { (\$ billion) }\end{array}$ & $\begin{array}{l}\text { Incremental } \\
\text { Cost/Death Averted } \\
\text { (\$ million) }\end{array}$ \\
\hline 100 to $75 \mathrm{mrem} / \mathrm{y}$ & 18 & 0.2 & 10 \\
\hline 75 to $25 \mathrm{mrem} / \mathrm{y}$ & 22 & 2.4 & 100 \\
\hline 25 to $15 \mathrm{mrem} / \mathrm{y}$ & 1 & 1 & 1000 \\
\hline 15 to $10 \mathrm{mrem} / \mathrm{y}$ & -2 & 1 & net deaths increase \\
\hline 10 to $3 \mathrm{mrem} / \mathrm{y}$ & -15 & 3.4 & net deaths increase \\
\hline
\end{tabular}

\section{Exposures in Perspective}

Choosing a dose limit to control the derivation of soil cleanup guidelines should be done with reference to the factors described above: variations in background exposures, problems with measurement of low concentrations of radionuclides and the low cost-effectiveness associated with the proposed EPA standard. Table 5-8 shows average background doses in the United States, selected dose limits, background doses measured near BNL and exposure associated with BNL operations.

\section{ARARS, Dose Limits and Risk Levels Used by at Other Superfund Sites With Radioactively Contaminated Soil}

Under CERCLA, remedial actions must comply with federal and state environmental laws that are legally applicable or are relevant and appropriate. ARARS are defined in (NCP 40 CFR 300):

- Applicable requirements are cleanup standards, standards of control, and other substantive environmental protection requirements, criteria or limitations promulgated under federal or state law that specifically address a hazardous substance, pollutant, contaminant, remedial action, location or other circumstance at a CERCLA site.

- Relevant and appropriate requirements are cleanup standards, standards of control, and other substantive environmental protection requirements, criteria, or limitations promulgated under federal or state law that, while not "applicable" to a hazardous substance, pollutant, contaminant or remedial action, location, or other circumstance at a CERCLA site, address problems or situations sufficiently similar to those encountered at the CERCLA site that their use is well suited to the particular site. 
Table 5-8. Selected exposures and dose limits and associated risks.

\begin{tabular}{|c|c|c|}
\hline Dose & Limit or Source of Exposure & Risk $^{1}$ \\
\hline $300 \mathrm{mrem} / \mathrm{y}$ & average total background exposure in US & $1 \times 10^{-2}$ \\
\hline $200 \mathrm{mrem} / \mathrm{y}$ & average exposure from radon & $7 \times 10^{-3}$ \\
\hline \multirow[t]{6}{*}{$100 \mathrm{mrem} / \mathrm{y}$} & average background (excluding radon) & $4 \times 10^{-3}$ \\
\hline & EPA proposed for the public, all sources & \\
\hline & DOE Order 5400.5 for the public; all sources & \\
\hline & $\begin{array}{l}\text { DOE proposed } 10 \text { CFR Part } 834 \text { for the } \\
\text { public, all sources }\end{array}$ & \\
\hline & NRC licensed operations & \\
\hline & ICRP and NCRP, all sources & \\
\hline $75 \mathrm{mrem} / \mathrm{y}$ & $\begin{array}{l}\text { proposed limit (EPA) for soils if institutional } \\
\text { controls fail }\end{array}$ & $3 \times 10^{-3}$ \\
\hline $\begin{array}{l}64 \mathrm{mrem} / \mathrm{y} \\
(49-76 \mathrm{mrem} / \mathrm{y})\end{array}$ & $\begin{array}{l}\text { background gamma exposure at BNL (1993) } \\
\text { and surrounding area }\end{array}$ & $1 \times 10^{-3}$ \\
\hline $25 \mathrm{mrem} / \mathrm{y}$ & NCRP recommendation, single source & $4 \times 10^{-4}$ \\
\hline \multirow[t]{2}{*}{$15 \mathrm{mrem} / \mathrm{y}$} & $\begin{array}{l}\text { EPA proposed for release of site, active } \\
\text { controls acceptable }\end{array}$ & $2 \times 10^{-4}$ \\
\hline & proposed NRC limit for D\&D & \\
\hline \multirow[t]{2}{*}{$10 \mathrm{mrem} / \mathrm{y}$} & NYS TAGM for soils & $2 \times 10^{-4}$ \\
\hline & EPA NESHAPS, routine air emissions & \\
\hline $4 \mathrm{mrem} / \mathrm{y}$ & EPA drinking water standards & $6 \times 10^{-5}$ \\
\hline $1 \mathrm{mrem} / \mathrm{y}$ & BNL operations at site boundary & $2 \times 10^{-5}$ \\
\hline
\end{tabular}

individual lifetime fatal cancer risk, $5 \times 10^{-4}$ deaths/rem, assume 70 year exposure for background exposures, 30 years for dose limits. 
- To be Considered (TBC) criteria is a category that includes nonpromulgated criteria, advisories, and guidance issued by federal or state governments that are not legally binding and do not have the status of potential ARARS. However, pertinent TBCs will be considered along with the ARARS in determining the necessary level of cleanup or technology requirements.

USEPA reviewed cleanup decisions made under Superfund for sites contaminated with radioactive material (EPA 1995, 1993b). Many of these sites used the UMTRCA cleanup standard (10 CFR 190) of total radium of $5 \mathrm{pCi} / \mathrm{g}$ in surface soil and $15 \mathrm{pCi} / \mathrm{g}$ below the surface (approximately $10^{-3}$ excess cancer risk). The majority of sites selected cleanup levels with residual risk levels between $10^{-3}$ and $10^{-4}$. The ARARS and To Be Considered Guidelines selected for the 18 RODS (Record of Decision) reviewed by USEPA (EPA, 1993b) are summarized in Table 5-9.

Recent (1990-1995) RODS for the Fernald Environmental Management Project (FEMP), the 100 Area at Hanford, and the Chemical Plant Area at Weldon Spring (Table 5-10) were reviewed.

FEMP generally derived cleanup guidelines using the USEPA Superfund Approach (USEPA) and an identified risk level of $10^{-5}$ to $10^{-6}$ (Table 5-10; USDOE 1994a, 1994b; 1995d, 1995e, 1995f). Hanford is using the proposed EPA $15 \mathrm{mrem} / \mathrm{y}$ dose limit to derive soil cleanup guidelines, with the provision that deep contamination ( 15 feet) may sometimes be left in place with additional institutional controls if the costs or environmental effects of excavation are too high (USDOE 1995a).

Weldon Spring developed cleanup criteria that generally fall within the EPA Superfund range of $10^{-6}$ to $10^{-4}$ for open space use with higher risks for residential uses (USDOE 1993). ALARA goals that field excavation is expected to meet were set below the risk-based guidelines. ${ }^{226} \mathrm{Ra},{ }^{228} \mathrm{Ra},{ }^{230} \mathrm{Th}$ and ${ }^{232} \mathrm{Th}$ were treated as a group with a guideline of $6.2 \mathrm{pCi} / \mathrm{g}$ (including background) and an ALARA goal of $5 \mathrm{pCi} / \mathrm{g}$ (including background). ${ }^{238} \mathrm{U}$ guidelines were set at $120 \mathrm{pCi} / \mathrm{g}$ with an ALARA goal of $30 \mathrm{pCi} / \mathrm{g}$ (including background). 
Table 5-9. ARARS and TBCs for radioactively contaminated sites reviewed by EPA (18 RODS, signed prior to 1991, from EPA, 1993b).

\begin{tabular}{|c|c|c|}
\hline SITE & RADIONUCLIDES & ARARS and TBCs \\
\hline $\begin{array}{l}\text { Glen Ridge Radium } \\
\text { Site (New Jersey) }\end{array}$ & $\begin{array}{l}\text { radium, radon, radon } \\
\text { progeny }\end{array}$ & $\begin{array}{l}40 \text { CFR 192: } \\
\text { radium in soil } 5 \mathrm{pCi} / \mathrm{g} ; 15 \mathrm{pCi} / \mathrm{g} \\
\text { gamma dose } 20 \mu \mathrm{R} / \mathrm{h} \\
\text { radon } 0.02 \mathrm{WL} \text { annual avg., } 0.03 \mathrm{max} \text {. } \\
\text { NCRP Report No. } 77 \\
\text { ingestion in vegetables, } \\
40 \mathrm{pCi} / \mathrm{g} \text { radium in soil }\end{array}$ \\
\hline $\begin{array}{l}\text { Montclair West } \\
\text { Orange Site (New } \\
\text { Jersey) }\end{array}$ & $\begin{array}{l}\text { radium, radon, radon } \\
\text { progeny }\end{array}$ & $\begin{array}{l}40 \text { CFR 192: } \\
\text { radium in soil } 5 \mathrm{pCi} / \mathrm{g} ; 15 \mathrm{pCi} / \mathrm{g} \\
\text { gamma dose } 20 \mu \mathrm{R} / \mathrm{h} \\
\text { radon } 0.02 \mathrm{WL} \text { annual avg., } 0.03 \mathrm{max} \text {. } \\
\text { NCRP Report No. } 77 \\
\text { ingestion in vegetables, } \\
40 \mathrm{pCi} / \mathrm{g} \text { radium in soil }\end{array}$ \\
\hline $\begin{array}{l}\text { Radium Chemical } \\
\text { Company (New York) }\end{array}$ & $\begin{array}{l}\text { radium, radon, radon } \\
\text { progeny }\end{array}$ & $\begin{array}{l}40 \text { CFR 192: } \\
\text { radium in soil } 5 \mathrm{pCi} / \mathrm{g} ; 15 \mathrm{pCi} / \mathrm{g} \\
\text { gamma dose } 20 \mu R / \mathrm{h} \\
\text { radon } 0.02 \mathrm{WL} \text { annual avg., } 0.03 \text { max. } \\
\text { NRC Reg. Guide } 1.86 \\
\text { surface contamination fixed: } \\
100 \mathrm{dpm} / 100 \mathrm{~cm}^{2} \text {, avg. } \\
300 \mathrm{dpm} / \mathrm{cm}^{2}, \mathrm{max} . \\
\text { removable: } 20 \text { dpm } / 100 \mathrm{~cm}^{2} \\
\text { NY State Regulations } \\
\text { 6NYCRR; } 12 \mathrm{NYCRR}\end{array}$ \\
\hline $\begin{array}{l}\text { Maxey Flats Disposal } \\
\text { Site (Kentucky) }\end{array}$ & $\begin{array}{l}\text { H-3, Ra-226, Co-60, } \\
\text { Cs-137, C-14, Sr-90, } \\
\text { Pu-239. }\end{array}$ & $\begin{array}{l}10 \text { CFR } 61 \\
25 \mathrm{mrem} / \mathrm{y} \text { all pathways } \\
10 \mathrm{mrem} / \mathrm{y} \text { air pathways } \\
40 \text { CFR } 141 \\
4 \mathrm{mrem} / \mathrm{y} \text { drinking water pathway } \\
10^{-6} \text { to } 10^{-4} \text { risk }\end{array}$ \\
\hline $\begin{array}{l}\text { United Nuclear } \\
\text { Corporation (New } \\
\text { Mexico) }\end{array}$ & $\begin{array}{l}\text { Ra-226, Ra-228, } \\
\text { gross alpha }\end{array}$ & $\begin{array}{l}40 \text { CFR } 141 \\
\text { radium } 5 \mathrm{pCi} / \mathrm{L} \text { in ground water } \\
\text { State NMWQA } \\
\mathrm{U}-238,5 \mathrm{mg} / \mathrm{l}\end{array}$ \\
\hline $\begin{array}{l}\text { Weldon Spring } \\
\text { Quarry/Plant/Pits } \\
\text { Interim RA Quarry } \\
\text { Bulk Waste (Missouri) }\end{array}$ & $\begin{array}{l}\text { U-238, Th-232, } \\
\text { Th-230, Ra-228, } \\
\text { Ra-226 }\end{array}$ & $\begin{array}{l}40 \text { CFR } 61 \\
\text { NESHAPS } \\
\text { Missouri Rn-222 standard } \\
1 \mathrm{pCi} / \mathrm{L} \\
\text { DOE orders } \\
5400.5(100 \mathrm{mrem} / \mathrm{y}) \text { and } 5480.11\end{array}$ \\
\hline $\begin{array}{l}\text { Denver Radium Site } \\
\text { Streets (Colorado) }\end{array}$ & $\begin{array}{l}\text { radium, radon, radon } \\
\text { progeny }\end{array}$ & $\begin{array}{l}40 \text { CFR } 192 \\
\text { radium: } 5 \mathrm{pCi} / \mathrm{g} \\
\text { supplemental standard indicated remedial } \\
\text { action may not be needed when } \\
\text { contamination in semi-permanent location }\end{array}$ \\
\hline
\end{tabular}


Table 5-9. cont.

\begin{tabular}{|c|c|c|}
\hline SITE & RADIONUCLIDES & ARARS and TBCs \\
\hline $\begin{array}{l}\text { Denver Radium Sites } \\
\text { (6 sites) } \text { (Colorado) }\end{array}$ & $\begin{array}{l}\text { radium, radon, radon } \\
\text { progeny }\end{array}$ & $\begin{array}{l}\text { 40 CFR 192: } \\
\text { radium in soil } 5 \mathrm{pCi} / \mathrm{g} ; 15 \mathrm{pCi} / \mathrm{g} \\
\text { gamma dose } 20 \mu R / \mathrm{h} \\
\text { radon } 0.02 \mathrm{WL} \text { annual avg., } 0.03 \text { max. } \\
10 \mathrm{CFR} 20 \\
\text { air conc. radium } 3 \mathrm{pCi} / \mathrm{m}^{3} \text { unrestricted } \\
30 \mathrm{pCi} / \mathrm{m}^{3} \text { restricted }\end{array}$ \\
\hline $\begin{array}{l}\text { Monticello Vicinity } \\
\text { Properties Project } \\
\text { (Utah) }\end{array}$ & $\begin{array}{l}\text { Th-230, U-238, } \\
\text { Ra-226, radon, radon } \\
\text { progeny }\end{array}$ & $\begin{array}{l}40 \text { CFR 192: } \\
\text { radium in soil } 5 \mathrm{pCi} / \mathrm{g} ; 15 \mathrm{pCi} / \mathrm{g} \\
\text { gamma dose } 20 \mu R / \mathrm{h} \\
\text { radon } 0.02 \mathrm{WL} \text { annual avg., } 0.03 \text { max. } \\
10 \mathrm{CFR} 20 \\
\text { air conc. radium } 3 \mathrm{pCi} / \mathrm{m}^{3} \text { unrestricted } \\
30 \mathrm{pCi} / \mathrm{m}^{3} \text { restricted } \\
\text { DOE Guidelines } \\
\text { soil hot spot criteria } 100 \mathrm{mrem} / \mathrm{y}\end{array}$ \\
\hline $\begin{array}{l}\text { Monticello Mill Tailings } \\
\text { Site (Utah) }\end{array}$ & $\begin{array}{l}\text { radium-226, radon, } \\
\text { radon progeny, } \\
\text { uranium }\end{array}$ & $\begin{array}{l}\text { 40 CFR 192: } \\
\text { radium in soil } 5 \mathrm{pCi} / \mathrm{g} ; 15 \mathrm{pCi} / \mathrm{g} \\
\text { gamma dose } 20 \mu \mathrm{R} / \mathrm{h} \\
\text { radon emissions at inactive mill sites } \\
20 \mathrm{pCi} / \mathrm{m}^{2}-\mathrm{sec} \\
\text { radon gas at edge of inactive tailings pile } \\
0.5 \mathrm{pCi} / \mathrm{L}\end{array}$ \\
\hline $\begin{array}{l}\text { Rocky Flats Plant } \\
\text { (DOE) Interim RA } 881 \\
\text { Hillside Area, } \\
\text { Groundwater OU-1 } \\
\text { (Colorado) }\end{array}$ & $\begin{array}{l}\text { radioactive materials } \\
\text { (gross alpha, beta, } \\
\text { uranium) }\end{array}$ & $\begin{array}{l}\text { Colorado groundwater quality standard } \\
\text { gross alpha } 15 \mathrm{pCi} / \mathrm{L} \\
40 \text { CFR } 141 \\
\text { MCLs gross beta } 50 \mathrm{pCi} / \mathrm{L} \\
\text { Colorado surface water standard } \\
\begin{array}{ll}\text { Am-241: } 4 \mathrm{pCi} / \mathrm{L} & \mathrm{H}-3 \quad 20,000 \mathrm{pCi} / \mathrm{L} \\
\text { Sr-89, } 90: 8 \mathrm{pCi} / \mathrm{L} & \text { U: } 40 \mathrm{pCi} / \mathrm{L}\end{array}\end{array}$ \\
\hline $\begin{array}{l}\text { Rocky Flats Plant } \\
\text { (DOE) Interim RA } \\
\text { South Walnut Creek } \\
\text { Surface Water, OU-2 } \\
\text { (Colorado) }\end{array}$ & $\begin{array}{l}\text { Pu-239, Pu-240, Am- } \\
241, \text { uranium }\end{array}$ & $\begin{array}{l}\text { Colorado WQCC surface water standards } \\
\text { Applicable action specific standards RCRA } \\
40 \text { CFR 262,263,264 268 }\end{array}$ \\
\hline $\begin{array}{l}\text { Teledyne Wah Chang } \\
\text { Albany (TWCA) } \\
\text { Interim RA for two } \\
\text { sludge ponds (Oregon) }\end{array}$ & $\begin{array}{l}\text { uranium, thorium, } \\
\text { radium }\end{array}$ & $\begin{array}{l}\text { removal and disposal of sludge: } \\
\text { Clean Air Act ( } 40 \text { CFR } 50-99 \text { ) } \\
\text { for controlling dust during excavation } \\
\text { Oregon State regulations: } \\
\text { Solid Waste Regulation, Health Division } \\
\text { Requirements, Environmental Cleanup } \\
\text { Rules }\end{array}$ \\
\hline
\end{tabular}

- 6 RODS signed for various Denver Radium sites 
Table 5-10. Dose limits and risk values used to derive radionuclide soil cleanup guidelines for several DOE sites.

\begin{tabular}{|c|c|c|}
\hline OU/Site Description & Radionuclide & Dose Limit, ARAR or Risk Limit \\
\hline \multicolumn{3}{|l|}{ Hanford (Washington) } \\
\hline $\begin{array}{l}\text { Hanford } 100 \text { Area; } \\
\text { OU 100-BC-1, OU 100-DR-1, } \\
\text { OU 100-HR-1; addresses } \\
\text { soils }\end{array}$ & $\begin{array}{l}\text { CO-60, Cs-137, } \\
\text { Eu-152, Eu-154, } \\
\text { Sr-90 }\end{array}$ & $\begin{array}{l}15 \text { mrem/y (based on EPA proposed limit), } \\
\text { allows some contamination to remain in } \\
\text { place where cleanup is not practicable }\end{array}$ \\
\hline \multicolumn{3}{|l|}{$\begin{array}{l}\text { Fernald Environmental } \\
\text { Management Project (Ohio) }\end{array}$} \\
\hline $\begin{array}{l}\text { OU5, impacted environmental } \\
\text { media (groundwater, soil, } \\
\text { sediment, flora, fauna) }\end{array}$ & $\begin{array}{l}\text { uranium, } \\
\text { radium, thorium }\end{array}$ & $\begin{array}{l}1 \times 10^{-6} \text { for user of undeveloped park; } \\
1 \times 10^{-5} \text { for offsite farmer; plus ALARA; } \\
\text { overrides all other RODS if more stringent } \\
\text { UMTRCA standards applicable, DOE orders } \\
\text { TBC, Federal and State MCLs are ARARS }\end{array}$ \\
\hline $\begin{array}{l}\text { OU4, K65 silos, metal oxide } \\
\text { silos, contaminated soils and } \\
\text { building material }\end{array}$ & $\begin{array}{l}\text { uranium, } \\
\text { thorium }\end{array}$ & $\begin{array}{l}1 \times 10^{-6} \text { for a trespasser under assumed } \\
\text { continual federal ownership } \\
\text { UMTRCA standards applicable, DOE } \\
\text { Orders TBC, Federal and State MCLs are } \\
\text { ARARS. }\end{array}$ \\
\hline $\begin{array}{l}\text { OU2, landfill, sludge ponds, } \\
\text { flyash piles, burial site, } \\
\text { berms, liners and soils }\end{array}$ & $\begin{array}{l}\text { radium, thorium, } \\
\text { uranium, Cs-137 }\end{array}$ & $\begin{array}{l}1 \times 10^{-6} \text { for trespasser under assumed } \\
\text { continued federal ownership, } 1 \times 10^{-6} \text { for } \\
\text { offproperty residential farmer; thorium-230 } \\
\text { based on } 100 \text { mrem/y external gamma } \\
\text { derived in two stage process: risk based } \\
\text { preliminary guidelines modified using a } \\
\text { number of factors including access controls } \\
\text { and barriers. } \\
\text { UMTRCA standards applicable, Federal } \\
\text { and State MCLs, DOE Order } 5400.5 \text { TBC }\end{array}$ \\
\hline $\begin{array}{l}\text { OU1, waste pits, burn pits, } \\
\text { cleanvell }\end{array}$ & $\begin{array}{l}\text { uranium, } \\
\text { thorium }\end{array}$ & $\begin{array}{l}2 \times 10^{-6} \text { for a trespasser under assumed } \\
\text { continual federal ownership } \\
\text { UMTRCA standards applicable, DOE } \\
\text { Orders TBC, Federal and State MCLs are } \\
\text { ARARS. }\end{array}$ \\
\hline Weldon Spring (Kentucky) & & \\
\hline $\begin{array}{l}\text { Chemical Plant, waste sludge } \\
\text { and soil }\end{array}$ & $\begin{array}{l}\text { radium, thorium, } \\
\text { uranium }\end{array}$ & $\begin{array}{l}10^{-6} \text { to } 10^{-4} \text { for open space use, } 10^{-2} \text { to } 10^{-6} \\
\text { for residential use, ALARA goals set lower } \\
\text { UMTRCA standards applicable, DOE } \\
\text { Orders TBC }\end{array}$ \\
\hline
\end{tabular}




\section{Rationale for USEPA Proposed Dose Limit}

In its Proposed Radiation Site Cleanup Regulation, EPA chose $15 \mathrm{mrem} / \mathrm{y}$ because it believed that the 15 mrem standard provides an acceptable level of protection for the public, while standards less stringent would not provide an acceptable level of protection. Acceptable level was defined as consistent with the generally accepted range of $10^{-4}$ to $10^{-6}$. The $15 \mathrm{mrem} / \mathrm{y}$ standard corresponds to an estimated lifetime incidence risk of cancer of about $3 \times 10^{-4}$ (30 year exposure, fatal cancer risk $2.3 \times 10^{-4}$ ).

EPA determined that "a cleanup level more stringent than $15 \mathrm{mrem}$ would not be justifiable because below this level the incremental risks from remedial action begin to outweigh the incremental benefits, the technical difficulties of measuring more stringent cleanup levels increase, and the increased costs would not be reasonable compared to the small increase in benefits.(EPA 1995a)". EPA did not choose $10 \mathrm{mrem} / \mathrm{y}$ as the standard because cleaning to 10 rather than $15 \mathrm{mrem} / \mathrm{y}$ results in 2 additional deaths across all sites, and because the incremental cost was $\$ 1$ billion. EPA also determined that the 15 $\mathrm{mrem} / \mathrm{y}$ represents an acceptable fraction of the $100 \mathrm{mrem} / \mathrm{y}$ recommendation of total public exposures from sources other than background, occupational and medical practices suggested by ICRP and NCRP.

\section{Summary and Recommendations for BNL Dose Limit}

No ARARS are applicable to the cleanup of other radionuclides in soil at BNL. Guidelines, proposed regulations and DOE orders that are TBC include:

- EPA Proposed Radiation Site Cleanup Regulation; meant for release of sites, $15 \mathrm{mrem} / \mathrm{y}$ that may be met by institutional controls; $75 \mathrm{mrem} / \mathrm{y}$ to rural resident if controls fail. Groundwater MCLs must be met (if technically practicable) or exposures to contaminants in water can be limited using institutional controls.

- DOE Order 5400.5 and Proposed Regulation 10 CFR Part 834; 100 $\mathrm{mrem} / \mathrm{y}$ from all sources except background, medical and occupational exposures; $30 \mathrm{mrem} / \mathrm{y}$ from DOE operations. Soil guidelines should be derived as a percentage of these limits. MCLs must be met. Soil guidelines for radium are $5 \mathrm{pCi} / \mathrm{g}$.

- NYS TAGM (NYS, 1993); $10 \mathrm{mrem} / \mathrm{y}$, may consider institutional controls.

EPA found that a dose limit of $10 \mathrm{mrem} / \mathrm{y}$ would be difficult to measure, that it is low compared to the natural variation in natural background radiation that may be observed across a given site, and that below $15 \mathrm{mrem} / \mathrm{y}$ costs were excessive and no deaths were averted. Similar problems occur with a 15 $\mathrm{mrem} / \mathrm{standard}$ for rural residential uses.

The $15 \mathrm{mrem} / \mathrm{y}$ limit is a conservative limit that will be difficult to meet and does not consider the high costs and small benefits associated with meeting a dose limit so close to background. EPA has insisted that BNL derive guidelines 
based on a $15 \mathrm{mrem} / \mathrm{y}$ dose limit, and New York State requested a $10 \mathrm{mrem} / \mathrm{y}$ limit.

For deriving soil cleanup guidelines the recommendation is to: plan to meet a $15 \mathrm{mrem} / \mathrm{y}$ dose limit with the use of institutional controls (in the form mostly of alternative land uses), as well as $75 \mathrm{mrem} / \mathrm{y}$ (to a suburban resident) if controls fail. This commitment to a $15 \mathrm{mrem} / \mathrm{y}$ limit should be modified by the words "when practicable". When costs, human health or ecological risks are excessive for one or all of the identified remedial alternatives, alternate dose limits for soil cleanup guidelines and or remedial actions that do not involve soil excavation (i.e. capping, physical barriers, institutional controls) should be considered.

Earlier guidelines derived for BNL have treated the $5 \mathrm{pCi} / \mathrm{g}$ limit for radium (UMTRCA 40 CFR Part 192; DOE Order 5400.5) as a separate limit not included in the overall dose limit for radionuclides in soil (BNL, 1996). The approach described here suggests including the dose from radium in the overall 15 $\mathrm{mrem} / \mathrm{y}$ dose limit. However, cleanup to a $5 \mathrm{pCi} / \mathrm{g}$ level is not cost-effective at $\mathrm{BNL}$, and DOE may decide to use the $5 \mathrm{pCi} / \mathrm{g}$ guideline for radium, consistent with DOE Order 5400.5 . 


\section{IMPACTS TO GROUNDWATER}

\section{Introduction}

Because of the importance of the aquifer underlying BNL as a future resource, assessing potential impacts to groundwater is an important part of the approach for deriving soil cleanup guidelines for BNL. RESRAD can be used as a screening tool to assess worst-case potential impacts, but it is too simple and conservative to provide realistic estimates of the dose from ingestion of radionuclides in groundwater. Groundwater models already in use at BNL can be used to estimate potential impacts to groundwater when a RESRAD calculation suggests a potential problem.

\section{RESRAD Estimates}

Table 6-1 gives worst-case groundwater concentrations predicted beneath the waste site for $1 \mathrm{pCi} / \mathrm{g}$ of radionuclides in soil. These calculations are based on the generic site conditions summarized in Tables in Appendix I. Table 6-1 also provides concentration conversion factors that allow calculation of the dose associated with each radionuclide; current MCLs; and a screening soil concentration that would result in the MCL (based on conservative RESRAD model). Conversion factors used in Table 6-1 are from EPA (1991c) requlatory agencies may require use of more conservative converion factoprs in EPA (1976). Maximum concentrations in groundwater occur at different time periods for different radionuclides (Table 6-1).

These concentrations are the maximum value reached over 1,000 years and are based on the generic site assumptions used to derive the generic preliminary guidelines for BNL (e.g. depth to groundwater). Site specific predictions can be developed by running RESRAD using site specific physical parameters such as depth to groundwater and the size of the contaminated area.

Table 6-2 gives the concentrations of the radionuclides that migrate to groundwater over 1,000 years ( $\mathrm{Sr}-90, \mathrm{Ra}-226, \mathrm{U}-234, \mathrm{U}-235, \mathrm{U}-238$ ) assuming soil concentrations beginning at time zero. Figures 6-1 and 6-2 show how the concentrations (and associated doses) change in groundwater over time for these isotopes for $1 \mathrm{pCi} / \mathrm{g}$ in soil at time zero.

Table 6-3 gives USEPA and NYS MCLs, against which these predicted groundwater concentrations can be compared. RESRAD estimates of groundwater impact can also be used to estimate the collective dose (and risk) to future onsite receptors. 
Table 6-1. Peak concentrations in groundwater beneath site per unit concentration in soil (time of peak concentration in years assuming generic site conditions and soil concentrations at time zero); concentration conversion factors (water ingestion, based on $2 \mathrm{~L} / \mathrm{d}$; lifetime exposure); USEPA MCLs and associated screening soil concentrations.

\begin{tabular}{|c|c|c|c|c|c|}
\hline Radionuclide & $\begin{array}{l}\text { Water:Soil } \\
\text { Ratio } \\
\text { (pCi/L per } \\
\text { pCi/g) }\end{array}$ & $\begin{array}{c}\text { Time of } \\
\text { Peak Conc } \\
\text { (y) }\end{array}$ & $\begin{array}{l}\text { Conc. Conversion } \\
\text { Factor } \\
\text { pCi/l per mrem } / y^{2}\end{array}$ & $\begin{array}{c}\text { USEPA } \\
M^{3}{ }^{3}(p C i / L) \\
\text { (EPA 1991c } \\
\text { conversion } \\
\text { factors) }\end{array}$ & $\begin{array}{l}\text { Screening Soil } \\
\text { Conc. Equivalent } \\
\text { to } \mathrm{MCL} \\
\text { (pCi/g) }\end{array}$ \\
\hline Americium-241 ( $\alpha)$ & 0 & 210 & - & 15 & $\mathrm{NC}$ \\
\hline Cesium-137 ( $\beta)$ & 0 & - & 30 & 119 & $\mathrm{NC}$ \\
\hline Cobalt-60 ( $\beta)$ & 0 & - & 55 & 218 & $\mathrm{NC}$ \\
\hline Europium-152 ( $\beta$ ) & 0 & - & 210 & 841 & NC \\
\hline Europium-154 ( $\beta)$ & $\mathbf{0}$ & $\overline{-}$ & 143 & 573 & $\mathrm{NC}$ \\
\hline Europium-155 ( $\beta$ ) & 0 & $\overline{-}$ & 898 & 3590 & $\mathrm{NC}$ \\
\hline Plutonium-238 $(\alpha)$ & 0 & 560 & -- & 15 & NC \\
\hline Plutonium-239 $(\alpha)$ & 0 & 725 & - & 15 & NC \\
\hline Plutonium-240 $(\alpha)$ & 0 & 700 & -- & $\overline{15}$ & NC \\
\hline Radium-226 ( $\alpha)$ & $1.4 \times 10^{-4}$ & $1000^{4}$ & -- & 5 & 7,143 \\
\hline Strontium-90 ( $\beta)$ & 6.8 & 70 & 10.5 & 42 & 1.2 \\
\hline Uranium-234 $(\alpha)$ & 8.2 & 540 & -- & 15 & 1.8 \\
\hline Uranium-235 (a) & 8.2 & 540 & - & 15 & 1.8 \\
\hline Uranium-238 $(\alpha)$ & 4.1 & 849 & - & 15 & 3.7 \\
\hline
\end{tabular}

Concentration predicted by RESRAD directly under source term.

2 Calculated for beta emitters from Tables in FR 56:138; EPA (1991c) Proposed National Primary Drinking Water Regulations (assumes 2l/d; lifetime exposure); based on latest ICRP models and parameter values for calculating dose (ICRP 60; ICRP, 1991).

${ }^{3}$ EPA (1976), EPA-570/9-76-003; Current National Interim Primary Drinking Water Regulations: MCL for gross $\alpha$ emitters is $15 \mathrm{pCi} / \mathrm{L}$; for gross $\beta$ emitters $4 \mathrm{mrem} / \mathrm{y}$; for ${ }^{226} \mathrm{Ra}$ plus ${ }^{228} \mathrm{Ra} 5 \mathrm{pCi} / \mathrm{L}$. Concentrations of beta emitters associated with $4 \mathrm{mrem} / \mathrm{y}$ calculated from new ICRP parameters as given in Proposed Drinking Water Standards (EPA, 1991c); concentrations calculated based on factors in EPA (1976) are smaller - see table 6-3.

${ }^{4}$ Radium concentrations are small $\left(1.4 \times 10^{-4} \mathrm{pCi} / \mathrm{L}\right)$ but do not reach a peak in 1,000 years. NC -- Radionuclide not predicted to migrate to groundwater, minimum guideline not calculated. 
Table 6-2. RESRAD modeled worst-case concentrations of Sr-90, Ra-226, U$234, U-235$ and $U-238$ per $\mathrm{pCi} / \mathrm{g}$ over 1,000 years, assuming soil concentrations at time zero.

\begin{tabular}{|c|c|c|c|c|c|}
\hline \multirow[t]{2}{*}{ time (years) } & \multicolumn{5}{|c|}{ CONCENTRATION (pCIIL) } \\
\hline & Sr-90 & $U-234$ & U-235 & U-238 & Ra-226 \\
\hline 0 & $0.00 E+00$ & $0.00 E+\infty$ & $0.00 E+00$ & $0.00 E+\infty 0$ & $0.00 E+\infty$ \\
\hline 10 & $0.00 E+00$ & $0.00 E+00$ & $0.00 E+\infty 0$ & $0.00 E+\infty$ & $0.00 E+\infty 0$ \\
\hline 20 & $0.00 E+\infty 0$ & $0.00 E+\infty$ & $0.00 E+00$ & $0.00 E+\infty$ & $0.00 E+00$ \\
\hline 30 & $0.00 E+00$ & $0.00 E+\infty$ & $0.00 E+00$ & $0.00 E+00$ & $0.00 E+00$ \\
\hline 40 & $0.00 E+00$ & $0.00 E+\infty$ & $0.00 E+00$ & $0.00 E+00$ & $0.00 \mathrm{E}+00$ \\
\hline 50 & $1.63 E+00$ & $0.00 E+00$ & $0.00 E+00$ & $0.00 E+00$ & $0.00 E+00$ \\
\hline 60 & $6.12 E+00$ & $0.00 E+00$ & $0.00 E+00$ & $0.00 E+\infty 0$ & $0.00 E+\infty 0$ \\
\hline 70 & $6.18 E+\infty 0$ & $0.00 E+00$ & $0.00 E+00$ & $0.00 E+00$ & $0.00 E+00$ \\
\hline 80 & $6.18 E+00$ & $0.00 E+\infty 0$ & $0.00 E+\infty 0$ & $0.00 E+00$ & $0.00 E+00$ \\
\hline 90 & $5.20 E+00$ & $0.00 E+\infty 0$ & $0.00 E+00$ & $0.00 E+00$ & $0.00 E+\infty 0$ \\
\hline 100 & $3.39 E+\infty 0$ & $0.00 E+\infty$ & $0.00 E+00$ & $0.00 E+00$ & $0.00 E+00$ \\
\hline 110 & $1.39 \mathrm{E}+00$ & $0.00 E+00$ & $0.00 E+00$ & $0.00 E+00$ & $0.00 E+00$ \\
\hline 120 & 5.69E-01 & $0.00 E+00$ & $0.00 E+00$ & $0.00 E+00$ & $0.00 E+00$ \\
\hline 130 & $2.33 E-01$ & $0.00 E+00$ & $0.00 E+\infty 0$ & $0.00 E+00$ & $0.00 E+00$ \\
\hline 140 & $9.54 E-02$ & $0.00 E+00$ & $0.00 E+00$ & $0.00 E+\infty 0$ & $0.00 E+00$ \\
\hline 150 & $3.91 E-02$ & $0.00 E+00$ & $0.00 E+00$ & $0.00 E+\infty 0$ & $0.00 E+00$ \\
\hline 160 & $1.60 \mathrm{E}-02$ & $0.00 E+00$ & $0.00 E+\infty 0$ & $0.00 E+00$ & $0.00 E+00$ \\
\hline 170 & $6.56 \mathrm{E}-03$ & $0.00 E+00$ & $0.00 E+00$ & $0.00 E+00$ & $0.00 E+00$ \\
\hline 180 & $2.69 \mathrm{E}-03$ & $0.00 E+00$ & $0.00 E+00$ & $0.00 E+00$ & $0.00 E+00$ \\
\hline 190 & $1.10 \mathrm{E}-03$ & $0.00 E+\infty 0$ & $0.00 E+00$ & $0.00 E+00$ & $0.00 E+00$ \\
\hline 200 & $4.51 E-04$ & $0.00 E+\infty 0$ & $0.00 E+\infty 0$ & $0.00 \mathrm{E}+00$ & $0.00 E+00$ \\
\hline 210 & $1.85 E-04$ & $0.00 E+00$ & $0.00 E+00$ & $0.00 E+\infty 0$ & $0.00 E+00$ \\
\hline 220 & $7.56 \mathrm{E}-05$ & $0.00 E+00$ & $0.00 E+00$ & $0.00 \mathrm{E}+00$ & $0.00 E+\infty 0$ \\
\hline 230 & $3.10 \mathrm{E}-05$ & $0.00 E+00$ & $0.00 E+00$ & $0.00 E+00$ & $0.00 E+00$ \\
\hline 240 & 1.27E-05 & $0.00 E+00$ & $0.00 E+00$ & $0.00 \mathrm{E}+00$ & $0.00 E+00$ \\
\hline 250 & $5.20 \mathrm{E}-06$ & $0.00 E+00$ & $0.00 E+00$ & $0.00 E+00$ & $0.00 E+00$ \\
\hline 260 & $2.13 E-06$ & $0.00 E+\infty 0$ & $0.00 E+00$ & $0.00 E+00$ & $0.00 E+\infty 0$ \\
\hline 270 & $8.71 E-07$ & $0.00 E+\infty 0$ & $0.00 E+00$ & $0.00 E+00$ & $0.00 E+00$ \\
\hline 280 & $3.57 E-07$ & $7.16 E-01$ & 7.17E-01 & $0.00 E+00$ & $3.94 E-09$ \\
\hline 290 & $1.46 E-07$ & $1.60 E+00$ & $1.60 E+00$ & $3.65 E-01$ & $1.37 E-08$ \\
\hline 300 & $5.98 E-08$ & $2.37 \mathrm{E}+\infty 0$ & $2.38 E+00$ & $7.79 E-01$ & 5.71E-08 \\
\hline
\end{tabular}


Table 6-2 (cont.)

\begin{tabular}{|c|c|c|c|c|c|}
\hline \multirow[t]{2}{*}{ time (years) } & \multicolumn{5}{|c|}{ CONCENTRATION (pCi/) } \\
\hline & Sr-90 & $U-234$ & U-235 & U-238 & $\operatorname{Ra-226}$ \\
\hline 310 & $2.45 E-08$ & $3.07 E+00$ & $3.07 E+00$ & $1.15 E+\infty 0$ & $1.20 E-07$ \\
\hline 320 & $1.00 \mathrm{E}-06$ & $3.68 \mathrm{E}+00$ & $3.68 \mathrm{E}+00$ & $1.48 \mathrm{E}+00$ & $2.34 E-07$ \\
\hline 330 & $4.11 E-09$ & $4.32 E+\infty 0$ & $4.32 E+\infty 0$ & $1.77 E+00$ & 3.77E-07 \\
\hline 340 & $1.68 \mathrm{E}-09$ & $4.71 E+\infty$ & $4.71 E+\infty 0$ & $2.03 E+00$ & 5.81E-07 \\
\hline 350 & $6.89 \mathrm{E}-10$ & $5.14 E+\infty 0$ & $5.14 E+00$ & $2.26 E+00$ & 8.55E-07 \\
\hline 360 & $2.82 E-10$ & $5.52 E+00$ & $5.52 E+00$ & $2.47 E+00$ & $1.20 \mathrm{E}-06$ \\
\hline 370 & $1.15 E-10$ & $5.86 E+00$ & $5.86 E+\infty 0$ & $2.66 \mathrm{E}+\infty$ & $1.60 \mathrm{E}-06$ \\
\hline 380 & $4.72 \mathrm{E}-11$ & $6.16 E+00$ & $6.16 E+\infty 0$ & $2.82 E+00$ & $2.09 E-06$ \\
\hline 390 & $1.93 \mathrm{E}-11$ & $6.42 \mathrm{E}+00$ & $6.42 E+00$ & $2.97 E+00$ & $2.65 E-06$ \\
\hline 400 & $7.92 \mathrm{E}-12$ & $6.66 \mathrm{E}+00$ & $6.66 \mathrm{E}+00$ & $3.10 \mathrm{E}+\infty$ & $3.29 E-06$ \\
\hline 410 & $3.24 \mathrm{E}-12$ & $6.87 E+00$ & $6.87 E+00$ & $3.21 E+\infty$ & $4.02 E-06$ \\
\hline 420 & $1.33 \mathrm{E}-12$ & $7.05 E+00$ & $7.06 E+00$ & $3.32 E+\infty$ & $4.85 E-06$ \\
\hline 430 & $5.43 E-13$ & $7.22 \mathrm{E}+\infty 0$ & $7.22 E+00$ & $3.41 E+\infty$ & $5.74 E-06$ \\
\hline 440 & $2.22 \mathrm{E}-13$ & $7.36 E+00$ & $7.37 E+00$ & $3.49 E+\infty 0$ & $6.74 E-06$ \\
\hline 450 & $9.09 \mathrm{E}-14$ & $7.49 E+00$ & $7.50 \mathrm{E}+00$ & $3.56 E+\infty$ & $7.83 E-06$ \\
\hline 460 & $3.72 E-14$ & $7.61 E+00$ & $7.61 E+\infty 0$ & $3.63 E+\infty$ & $9.02 E-06$ \\
\hline 470 & $1.52 E-14$ & $7.71 E+\infty 0$ & $7.71 E+\infty 0$ & $3.69 E+\infty 0$ & 1.03E-05 \\
\hline 480 & $6.23 E-15$ & $7.80 \mathrm{E}+00$ & $7.80 E+\infty 0$ & $3.74 E+\infty 0$ & $1.16 E-05$ \\
\hline 490 & $2.55 E-15$ & $7.88 E+00$ & $7.88 E+00$ & $3.78 E+00$ & $1.31 E-05$ \\
\hline 500 & $1.04 \mathrm{E}-15$ & $7.95 E+00$ & $7.95 E+00$ & $3.83 E+00$ & $1.47 E-05$ \\
\hline 510 & $4.27 \mathrm{E}-16$ & $8.01 E+00$ & $8.02 E+00$ & $3.86 E+\infty 0$ & $1.63 E-05$ \\
\hline 520 & $1.75 E-16$ & $8.07 E+00$ & $8.07 E+00$ & $3.89 E+\infty$ & $1.81 E-05$ \\
\hline 530 & $7.15 E-17$ & $8.12 E+00$ & $8.12 E+00$ & $3.92 E+\infty$ & $2.00 E-05$ \\
\hline 540 & 2.93E-17 & $8.16 E+00$ & $8.16 E+\infty 0$ & $3.95 E+\infty$ & 2.19E-05 \\
\hline 550 & $1.20 \mathrm{E}-17$ & $7.28 E+00$ & $7.28 E+00$ & $3.97 E+00$ & $2.40 E-05$ \\
\hline 560 & $4.90 E-18$ & $6.46 E+\infty 0$ & $6.46 E+00$ & $3.99 E+\infty$ & $2.62 \mathrm{E}-05$ \\
\hline 570 & $2.00 E-18$ & $5.73 E+00$ & $5.73 E+00$ & $4.01 E+\infty$ & $2.83 E-05$ \\
\hline 580 & $8.19 E-19$ & $5.08 E+00$ & $5.08 E+00$ & $4.03 E+\infty$ & $3.06 E-05$ \\
\hline 590 & 3.35E-19 & $4.51 E+00$ & $4.51 E+\infty 0$ & $4.04 E+\infty 0$ & $3.29 E-05$ \\
\hline 600 & $1.37 \mathrm{E}-19$ & $4.00 E+00$ & $4.00 E+00$ & $4.05 E+00$ & $3.54 E-05$ \\
\hline 610 & $5.61 E-20$ & $3.55 E+00$ & $3.55 E+\infty 0$ & $4.07 E+00$ & $3.78 E-05$ \\
\hline 620 & $2.29 \mathrm{E}-20$ & $3.15 E+00$ & $3.15 E+00$ & $4.08 E+\infty$ & $4.02 E-05$ \\
\hline 630 & $9.38 \mathrm{E}-21$ & $2.80 E+00$ & $2.79 E+00$ & $4.08 E+\infty$ & 4.27E-05 \\
\hline
\end{tabular}


Table 6-2 (cont.)

\begin{tabular}{|c|c|c|c|c|c|}
\hline \multirow[t]{2}{*}{ time (years) } & \multicolumn{5}{|c|}{ CONCENTRATION (PCiR) } \\
\hline & Sr-90 & U-234 & U-235 & U-238 & Ra-226 \\
\hline 640 & $3.84 E-21$ & $2.48 \mathrm{E}+00$ & $2.48 E+\infty 0$ & $4.09 E+00$ & $4.52 \mathrm{E}-05$ \\
\hline 650 & $1.57 \mathrm{E}-21$ & $2.20 \mathrm{E}+00$ & $2.20 E+\infty$ & $4.10 \mathrm{E}+00$ & $4.78 \mathrm{E}-05$ \\
\hline 660 & $6.41 E-22$ & $1.95 E+\infty$ & $1.95 \mathrm{E}+00$ & $4.11 E+00$ & 5.03E-05 \\
\hline 670 & $2.62 E-22$ & $1.79 E+\infty$ & $1.79 E+00$ & $4.11 E+\infty 0$ & 5.28E-05 \\
\hline 680 & $1.07 E-22$ & $1.54 E+\infty$ & $1.53 E+00$ & $4.12 \mathrm{E}+00$ & 5.54E-05 \\
\hline 690 & $4.38 E-23$ & $1.36 \mathrm{E}+\infty 0$ & $1.36 E+00$ & $4.12 E+\infty 0$ & $5.81 E-05$ \\
\hline 700 & $1.79 E-23$ & $1.21 E+00$ & $1.20 E+00$ & $4.12 E+00$ & $6.06 \mathrm{E}-05$ \\
\hline 710 & $7.33 E-24$ & $1.07 E+\infty$ & $1.07 E+00$ & $4.13 E+00$ & $6.32 \mathrm{E}-05$ \\
\hline 720 & $3.00 \mathrm{E}-24$ & $9.52 E-01$ & 9.47E-01 & $4.13 E+00$ & $6.58 \mathrm{E}-05$ \\
\hline 730 & $1.22 E-24$ & 8.44E-01 & $8.40 E-01$ & $4.13 E+00$ & $6.84 E-05$ \\
\hline 740 & $5.00 E-25$ & $7.49 E-01$ & $7.45 E-01$ & $4.14 E+00$ & $7.10 \mathrm{E}-05$ \\
\hline 750 & $2.05 E-25$ & $6.64 E-01$ & $6.60 \mathrm{E}-01$ & $4.14 E+00$ & 7.36E-05 \\
\hline 760 & $8.39 E-26$ & $5.89 E-01$ & $5.85 \mathrm{E}-01$ & $4.14 E+00$ & $7.62 \mathrm{E}-05$ \\
\hline 770 & $3.42 E-26$ & $5.23 \mathrm{E}-01$ & 5.19E-01 & $4.14 E+00$ & $7.88 \mathrm{E}-05$ \\
\hline 780 & $1.40 \mathrm{E}-26$ & $4.64 E-01$ & $4.60 \mathrm{E}-01$ & $4.14 E+00$ & $8.14 \mathrm{E}-05$ \\
\hline 790 & $5.71 E-27$ & 4.11E-01 & $4.08 E-01$ & $4.15 E+\infty 0$ & $8.40 \mathrm{E}-05$ \\
\hline 800 & $2.33 E-27$ & $3.65 E-01$ & $3.62 E-01$ & $4.15 E+00$ & $8.65 E-05$ \\
\hline 810 & $9.52 E-28$ & $3.24 E-01$ & $3.21 E-01$ & $4.15 E+00$ & $8.90 E-05$ \\
\hline 820 & $3.89 \mathrm{E}-28$ & $2.87 E-01$ & $2.84 E-01$ & $4.15 E+\infty$ & $9.19 \mathrm{E}-05$ \\
\hline 830 & $1.59 \mathrm{E}-28$ & $2.54 E-01$ & $2.52 E-01$ & $4.15 E+00$ & $9.41 \mathrm{E}-05$ \\
\hline 840 & $6.49 \mathrm{E}-29$ & $2.26 E-01$ & $2.26 E-01$ & $4.15 E+\infty 0$ & $9.66 E-05$ \\
\hline 850 & $2.65 E-29$ & $2.00 E-01$ & $1.98 \mathrm{E}-01$ & $4.10 \mathrm{E}+00$ & $9.92 \mathrm{E}-05$ \\
\hline 860 & $1.08 \mathrm{E}-29$ & 1.77E-01 & $1.75 \mathrm{E}-01$ & $3.65 E+00$ & $1.02 \mathrm{E}-04$ \\
\hline 870 & $4.43 E-30$ & $1.57 \mathrm{E}-01$ & $1.55 \mathrm{E}-01$ & $3.26 E+00$ & $1.04 E-04$ \\
\hline 880 & $1.81 \mathrm{E}-30$ & $1.39 \mathrm{E}-01$ & $1.38 \mathrm{E}-01$ & $2.90 E+00$ & $1.07 \mathrm{E}-04$ \\
\hline 890 & $7.38 \mathrm{E}-31$ & $1.24 E-01$ & $1.22 \mathrm{E}-01$ & $2.58 E+00$ & $1.09 E-04$ \\
\hline 900 & $3.01 E-31$ & $1.09 E-01$ & $1.08 \mathrm{E}-01$ & $2.30 E+00$ & $1.12 \mathrm{E}-04$ \\
\hline 910 & $1.23 E-31$ & $9.70 \mathrm{E}-02$ & $9.59 E-02$ & $2.05 E+00$ & $1.14 \mathrm{E}-04$ \\
\hline 920 & $5.02 E-32$ & $8.60 \mathrm{E}-02$ & $8.50 E-02$ & $1.82 E+\infty$ & 1.17E-04 \\
\hline 930 & $2.05 \mathrm{E}-32$ & $7.62 E-02$ & $7.53 \mathrm{E}-02$ & $1.62 E+\infty 0$ & $1.19 \mathrm{E}-04$ \\
\hline 940 & $8.37 E-33$ & $6.75 E-02$ & $6.67 E-02$ & $1.45 E+\infty$ & $1.21 E-04$ \\
\hline 950 & $3.42 \mathrm{E}-33$ & $5.99 E-02$ & $5.91 E-02$ & $1.29 E+\infty$ & $1.24 E-04$ \\
\hline 960 & $1.40 \mathrm{E}-33$ & $5.30 \mathrm{E}-02$ & $5.24 \mathrm{E}-02$ & $1.15 E+\infty$ & $1.26 \mathrm{E}-04$ \\
\hline 970 & $5.69 \mathrm{E}-34$ & $4.70 \mathrm{E}-02$ & $4.64 \mathrm{E}-02$ & $1.02 E+\infty 0$ & $1.29 \mathrm{E}-04$ \\
\hline 980 & $2.32 \mathrm{E}-34$ & 4.17E-02 & $4.11 E-02$ & $9.09 \mathrm{E}-01$ & $1.31 \mathrm{E}-04$ \\
\hline 990 & $9.48 E-35$ & $3.69 E-02$ & $3.64 E-02$ & $8.10 E-01$ & $1.33 E-04$ \\
\hline
\end{tabular}


Figure 6-1. Concentration ( $\mathrm{pCi} / \mathrm{l})$ and dose (mrem/yr) over time associated with $1 \mathrm{pCi} / \mathrm{g}$ of $\mathrm{Sr}-90, \mathrm{U}-234, \mathrm{U}-235$, and $\mathrm{U}-238$.
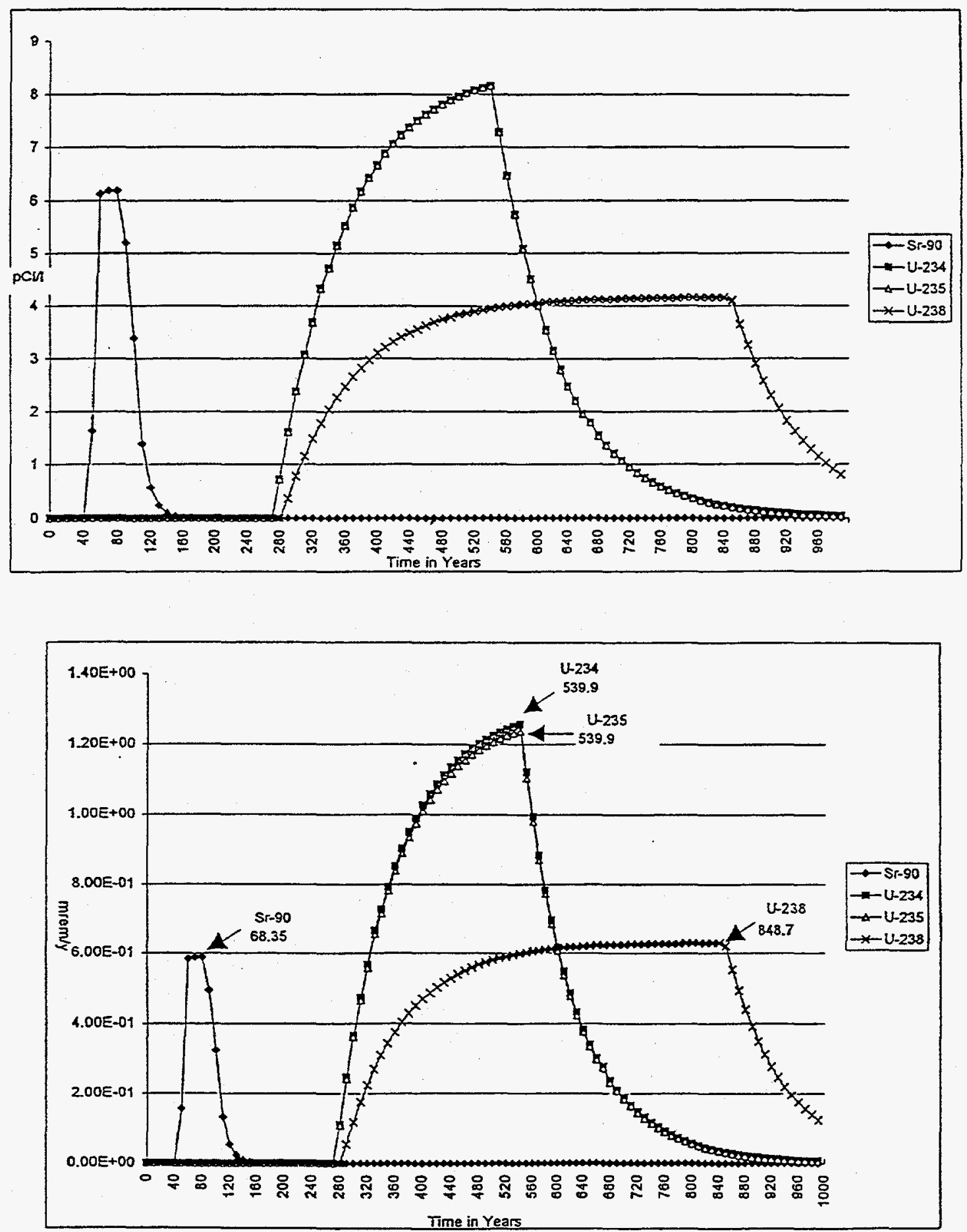
Figure 6-2. Concentration ( $\mathrm{pCi} / \mathrm{l})$ and dose (mrem/yr) over time associated with $1 \mathrm{pCi} / \mathrm{g}$ of Ra-226.
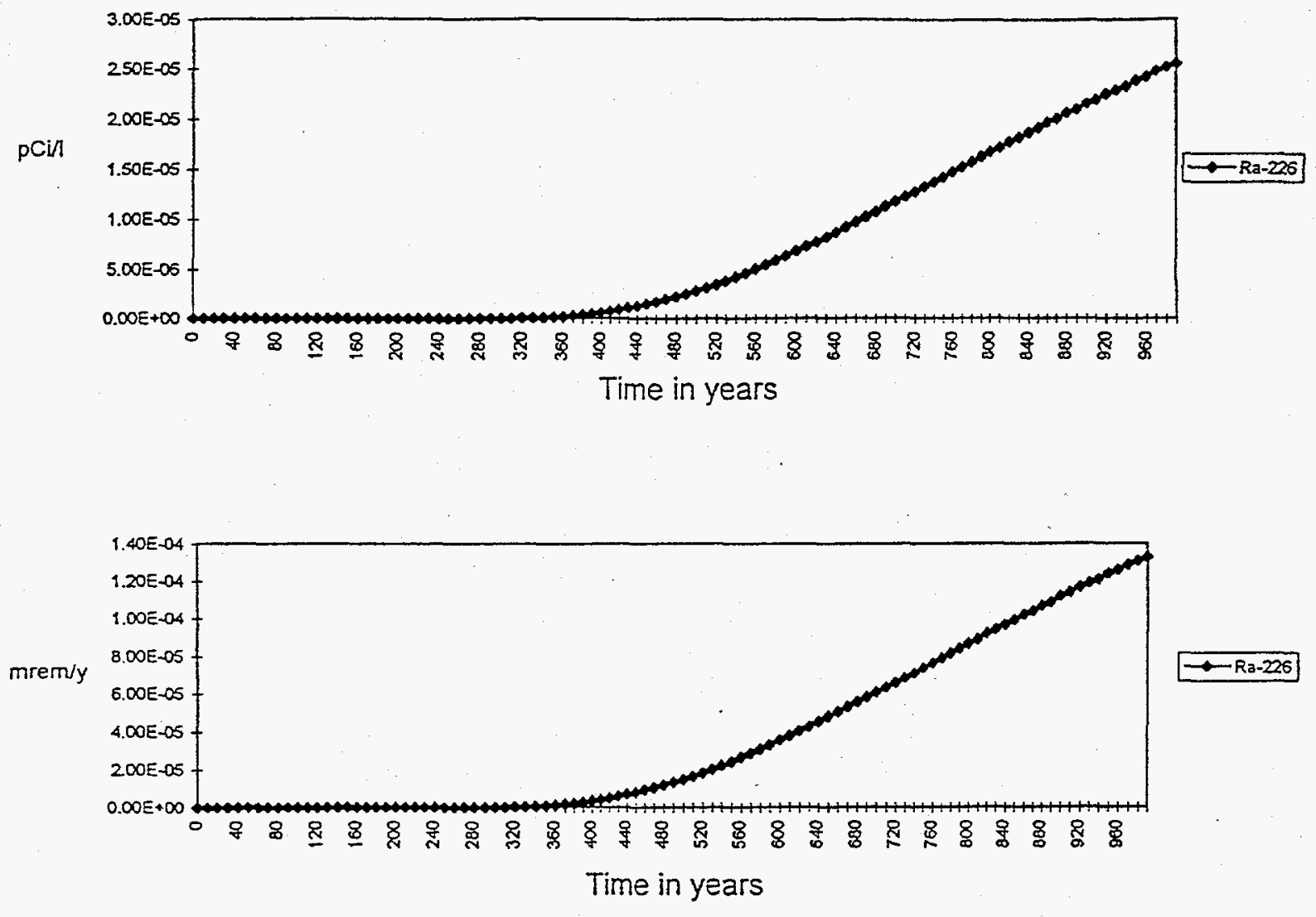
Table 6-3. USEPA and New York State MCLs.

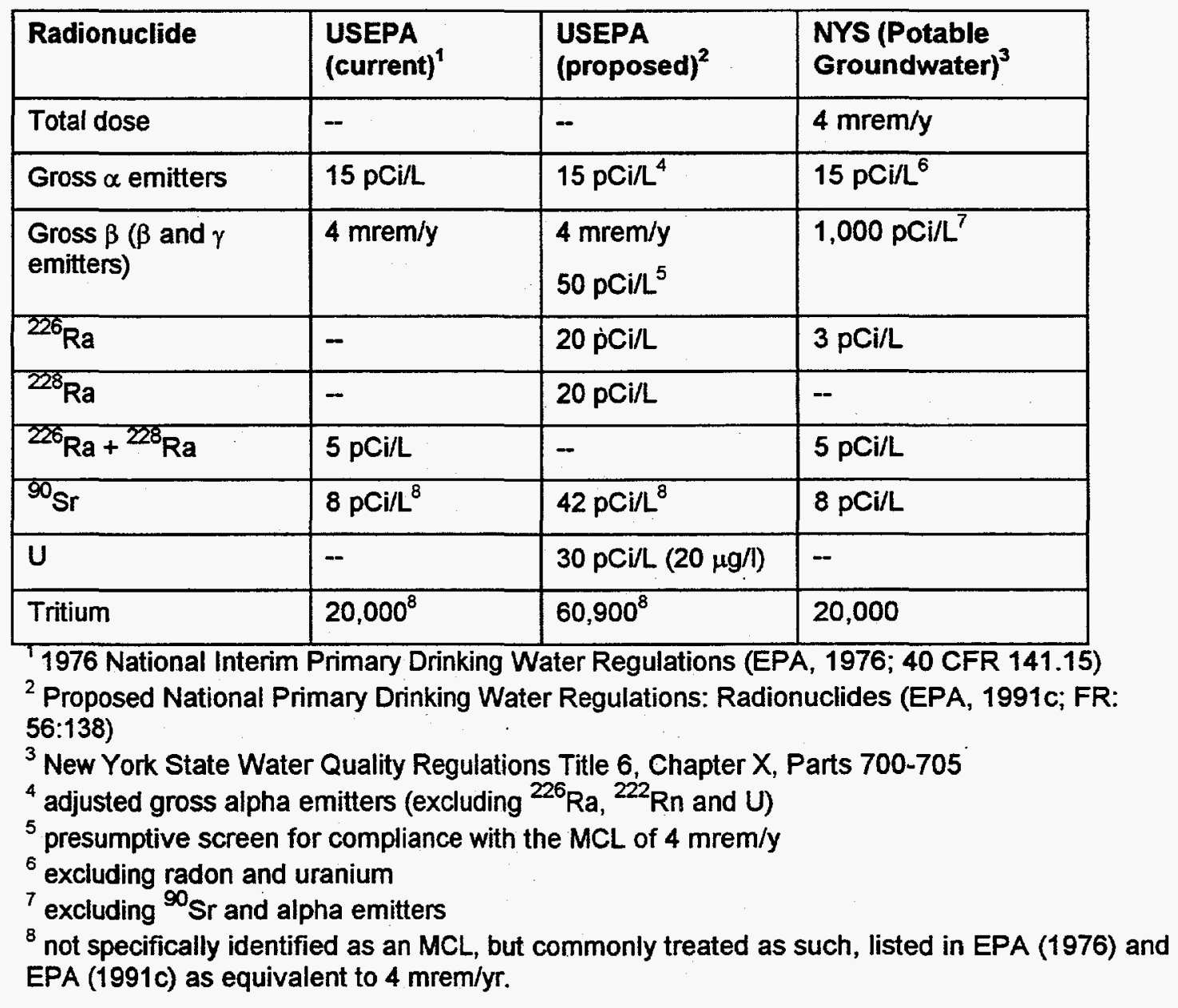

\section{RESRAD Assumptions}

RESRAD contains a simple one-dimensional groundwater model that tends to overestimate concentrations of radionuclides in ground water and cannot estimate concentrations in an offsite well. The model assumes no dispersivity, and the receptor well is assumed to be located at the downgradient edge of the contaminated zone. RESRAD does not solve the equations for solute transport in groundwater, but uses steady state or constant flow fields.

Because of these simplifications, the groundwater model in RESRAD should be considered a screening tool, and more sophisticated models used to estimate groundwater concentrations when there is concern that MCLs may be exceeded. 


\section{Recommendations for the BNL Approach}

Assess potential groundwater impacts in two steps.

- Use RESRAD to estimate the worst-case future concentration of radionuclides in groundwater beneath the waste site associated with a set of preliminary guidelines. Compare these concentrations to USEPA and NYS MCLs.

- If MCLs are exceeded in this analysis, perform a more detailed modeling analysis to estimate groundwater concentrations and doses for comparison to MCLs.

If this more accurate analysis suggests that MCLs may be exceeded, BNL should assess the net benefit associated with meeting MCLs, determine if meeting MCLs is practicable, and consider institutional controls or remedial technologies that will reduce or eliminate the groundwater pathway. This decision should be made taking into account the results of the net benefit analysis together with other regulatory and technical considerations. 


\section{NET BENEFIT ANALYSIS AND ALARA}

\section{Introduction}

In addressing clean-up of contaminated areas, ICRP indicates that the decision criteria should be "do no harm", that is, the net effect of a clean-up activity should be positive (ICRP, 1991). Cleaning up contaminated areas can have negative impacts, for example:

- Remediation workers can incur radiation exposure and accidental injury.

- Transport of wastes to disposal sites causes traffic deaths and injuries and worker and public radiation exposures, especially when large amounts of low-level wastes must be transported long distances.

- The natural ecology of an area is often disrupted. This is of particular concern where restricted access to a site has led to preservation of natural habitat for decades in areas where the surrounding area has experienced intensive development.

In its simplest form, net benefit analysis is simply a balancing of the positive and negative aspects of a decision. One explanation is that "Engineering, economic, environmental, social, and political concerns are brought to the table and traded off as a number of alternative plans are formulated and evaluated." (Robinson et al., 1995). One difficulty frequently raised about net benefit analysis is that it requires all parts of the decision to be reduced to common (usually monetary) terms so the arithmetic can be done, i.e., the benefits and the costs can each be summed and the difference between them calculated. Translating health risks or ecological values into monetary terms is controversial and reducing decisions to arithmetic is suspect.

Transformation into monetary terms, however, is not necessary in cases where decisions are fairly straightforward. In this case, for example, the following factors could be evaluated by the decision makers:

1) suitable future land use

2) clean-up levels for residual radioactive material

3) public health risk

4) worker health risk

5) preservation of wildlife habitat

6) cost of clean-up

What are the relationships? Increased clean-up usually leads to decreased public health risk, increased worker health risk, and increased destruction of habitat. Extensive clean-up based on achieving may yieid public health risks of $1 / 100,000$ life-time cancer, may result in destruction of habitat, extensive worker exposure and very high costs. A life-time risk guideline for the public of $1 / 1000$, however, might greatly reduce worker exposure, habitat 
destruction, and costs. The latter risk level is on the order of average exposures from radon gas. This is a range within which trade-offs might be made. Further flexibility can be achieved by land-use control. Residential use of land may require extensive clean-up to maintain acceptable risk, but using the land as a wildlife preserve can maintain the same low risk because the duration and extent of human exposure is much reduced.

These trade-offs may be controversial and difficult to agree on, but even when dealing with six parameters with different units and different values attached, as in the example, they are easily understood. This is not to say that the values of the various costs and benefits should not be quantified where possible. Quantification provides specific information that aids decision-making. The factors that are to be measured and the metric for quantification should be agreed upon. The arithmetic calculation of net benefit can be helpful when screening many alternatives or when the costs and benefits include many factors.

In making these trade-offs, the Water Resources Council (Robinson et al., 1995) recommends four broad decision criteria: completeness, effectiveness, efficiency and acceptability.

Net benefit analysis, whether done quantitatively or qualitatively, should be done incrementally. That is, the least cost feasible alternative should be compared with the next higher cost alternative and the question asked, "Is the incremental increase in benefit worth the incremental increase in cost?" That alternative should then be compared to the next higher alternative in the same way, and the process continued until the answer to the question is "No".

It is important to consider the timing of costs and benefits. Most of the costs occur in the present. Consider, for example, the cost of excavation and injuries to remediation workers. Most of the benefits occur in the future, some extending considerably into the future. It is generally agreed that future monetary costs should be discounted, but treatment of health and environmental impacts is controversial. This consideration is important for all cases, but especially for quantitative net benefit analysis.

\section{Net Benefit Analysis for Alternatives and Remedial Guidelines}

A calculation of the net benefit for each remedial alternative and its associated preliminary cleanup guidelines should be done as part of the FS phase of a CERCLA remedial action to help choose between alternatives. The approach suggested here provides methods to estimate the net benefit of a remedial alternative, and factors into the decision on the final option the level of protectiveness (i.e. dose limit and land use assumptions) embedded in the remedial guidelines for residual radioactivity in soil.

Methods to estimate costs of alternative remedial actions are well established and are routinely performed as part of the Feasibility Study phase of a CERCLA remedial action. Risk to workers and the general public can be 
estimated using simple models and assumptions (EPA, 1995a). Ecological values can be treated in a qualitative way, based on information presented in the Remedial Investigation Study for a specific AOC/OU and other data collected for the site.

First, the required data must be assembled. Then each of the parameters is described, and the method of derivation explained. In Section 8 , the qualitative approach to using these data in net benefit analysis is described in detail.

More prescriptive tools are available and may be used to calculate the net benefit of a particular remedial option and set of preliminary guidelines. A tool developed at the Brookhaven National Laboratory's ALARA Center can be used to calculate the net benefit of various remedial alternatives (and preliminary guidelines) selected by DOE for detailed evaluation. This tool is in the form of a software application called Radiological Assessment \& Design System (RADS). This software is described in more detail in Appendix IV. The major difference between the two approaches described here is that the RADS program requires that numerical values be assumed to describe the worth of a life saved or some ecological values (e.g. \$ per acre of wetland).

These methods can be used to:

- determine if the $15 \mathrm{mrem} / \mathrm{y}$ dose limit can be met without excessive costs, additional human health risks or destruction of important ecological values; and

- help choose among alternatives.

\section{Uncertainties}

Uncertainties in the parameters used to estimate the net benefit of remedial alternatives should be assessed. This is important when several very different technologies are being considered. Cost estimates associated with insitu vitrification, for example, may not be as certain as those associated with excavation and disposal, while an underestimate of contaminated soil volumes may have more of an impact on the final cost of alternatives that depend on excavation.

The risk estimates that go into the net benefit analysis are, of course uncertain, but these parameters are the same for all analyzed alternatives. Cost and volume estimates are more likely to be uncertain to different degrees, and reliance on a single cost estimate may result in an under-or over-estimate of the net benefit of a particular alternative, resulting in a cost-ineffective decision.

This method suggests performing a limited number of sensitivity analysis for the two or three preferred alternatives, where costs are varied within a reasonable range to see if a bad decision could be made if costs vary from what was assumed in the initial analysis. 


\section{ALARA Analysis for Superfund Sites Contaminated With Radioactive Materials}

ALARA

The policy of the DOE is to operate its facilities and conduct its research to maintain radiation exposures as far below the prescribed limits as is reasonably achievable. ALARA is defined in DOE Order 5480.11 as "An approach to radiation protection to control or manage exposures (both individual and collective to the work force and general public) as low as social, technical, economic, practical, and public policy considerations permit. As used in this Order, ALARA is not a dose limit but a process, which has the objective of dose levels as far below applicable limits of the Order as reasonably achievable."

To determine if a remedial alternative (and associated preliminary guideline) will reduce dose from radioactive contamination to as low as is reasonably achievable, a quantitative method or decision-making technique should be employed. DOE Order 5480.11 requires that design objectives use the optimization principles, such as those discussed in ICRP 37 (ICRP, 1983) when justifying changes in facility design to control occupational exposures. ICRP 55 (ICRP, 1989) also provides relevant guidance on optimization and the decision-making process. DOE Order 5400.5 requires that "...contractors develop a program to implement the ALARA process for all activities that cause dose to the general public." Furthermore, DOE Order 5400.5 and the DOE proposed rule 10 CFR 834 revised $8-25-95$ both state that "...The ALARA process shall document the societal, environmental, technological, economic, and public policy factors considered in decision-making, where exposures to radiation from DOE activities can occur, and shall include:

1) the maximum dose to members of the public;

2) the collective dose to the population;

3) doses to workers;

4) applicable alternative processes, such as alternative treatments of discharge streams, operating methods, or controls;

5) doses for each alternative evaluated;

6) cost for each alternative evaluated;

7) an examination of the changes in costs among alternatives, and,

8) societal and environmental (positive and negative) impact associated with alternatives."

ALARA Analysis of Preliminary Remediation Goals during the Design And Construction Planning Phase

After preliminary guidelines are developed and a remedial alternative selected, an ALARA process is used to cost-effectively reduce the residual levels below the levels associated with the $15 \mathrm{mrem} / \mathrm{y}$ dose limit. An ALARA 
analysis may find that levels cannot be cost-effectively reduced, since the dose limit in this case is so low.

The DOE has performed several site remediations and has numerous remedial actions that are planned. A methodology has evolved from these activities to evaluate the final remediation guideline that will result in radiation exposures being as low as reasonably achievable. It requires the use of risk assessment models to estimate present and future risks to both workers and the public for the current and expected land use of the site. It also requires data on how the radionuclide concentrations at the site will vary in time and space over the period of interest. Basically, the analysis involves calculating the volumes of soil, which is a surrogate for costs to remediate, that will require remediation over a range of remediation goals which is a surrogate for radiological risk (see example for BNL HWMF in Figure 7-1). The volumes / costs from these estimates will typically increase dramatically below a certain concentration / risk range. The ALARA level is the point below the identified dose limit where the ratio of the differential cost of protection and the differential risk is a minimum. During remediation, it is usually practical and cost-effective to exceed design requirements, e.g. removing an extra layer of soil. This provides an extra level of protection.

Figure 7-1. Cumulative soil volumes over a range of cleanup guidelines for Cs137 at the BNL HWMF.

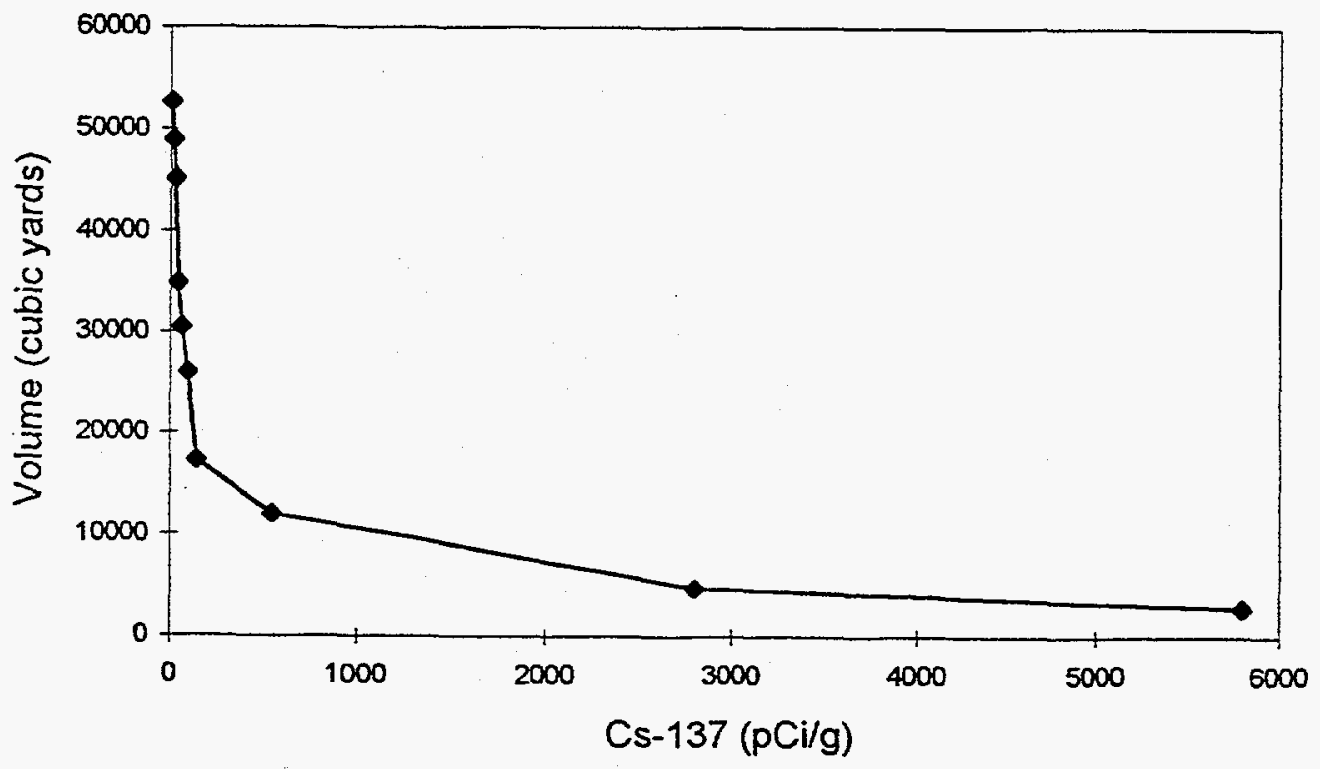




\section{ALARA Documentation}

Prior to and after completion of the final remedy the performance against remedial objectives identified in the Feasibility Study (including the final remedial guidelines for residual radioactivity in soil) should be monitored and documented. The documentation should provide a comprehensive record of the radiological conditions following the termination of the facility's operation and the final status after completion of decommissioning and environmental restoration activities. This information is needed to demonstrate that the agreed upon remedial goals and objectives were satisfied prior to the release of the site and that the dose from the remaining residual radioactive material is ALARA

\section{Hanford 100 Area Decision Framework}

An approach similar to the one suggested for BNL was accepted for the cleanup of the 100 Area at the Hanford Washington site. The 100 area at Hanford is the site of nine retired plutonium reactors. A recent ROD for three OUs in the 100 area (100-BC-1, 100-DR-1 and 100-HR-1) addresses liquid effluent disposal sites and uses a decision framework to allow some contamination to be left in place when excavation is not practicable. Important radionuclides in these waste areas include Co-60, Cs-137, Eu-152, Eu-154 and Sr-90 (USDOE, 1995a).

One of the stated objectives of the remedial action described in the ROD is:

"To the extent practicable, return soil concentrations to levels that allow for unlimited future use and exposure. Where it is not practicable to remediate to levels that will allow for unrestricted use in all areas, institutional controls and long-term monitoring will be required" (USDOE, 1995a; p 28)."

This ROD specifically allows consideration of the kind of costeffectiveness analysis suggested here for BNL. The basic approach is to meet the 15 mrem standard for residential use (and protection of ground water and the Columbia River) for shallow sites (top 15 feet). For sites where contamination is deep (below 15 feet).

"several factors will be considered in determining the extent of remediation including reduction of risk by decay of short-lived (half-life less than 30.2 years) radionuclides...protection of human health and the environment, remediation costs, sizing of the Environmental Restoration Disposal Facility, worker safety, presence of ecological and cultural resources, the use of institutional controls, and long term monitoring costs. The extent of remediation will also have to ensure that contaminant levels are at or below MCLs for protection of groundwater or AWQC for protection of the Columbia River." (USDOE, 1995a; p 38).

and 
"Institutional controls and long-term monitoring will be required for any sites where wastes are left in place that preclude unrestricted use" (USDOE 1995a, p 39).

\section{Recommendations for BNL Approach}

- Perform a net benefit analysis for the most favored remedial alternatives (including a consideration of the preliminary guidelines and their associated risks and benefits).

- When a net benefit analysis finds that costs and risks of alternatives and the preliminary guidelines are not excessive, accept guidelines derived from the $15 \mathrm{mrem} / \mathrm{y}$ as proposed by USEPA. This net benefit analysis can also be used to support a choice between remedial alternatives that have a net benefit based on $15 \mathrm{mrem} / \mathrm{yr}$. After cleanup is complete, document that the residual concentrations result in exposures that are ALARA.

- When a net benefit analysis for the identified alternatives shows that a 15 mrem/y dose limit results in costs and risks that obviously exceed the benefits (for alternatives still under consideration) develop alternate scenarios (e.g. alternate land uses) and dose limits for deriving guidelines and consider remedies that do not require excavation. Perform a set of net benefit analyses to determine the best solution. The best solution may be to choose one of the previously identified alternatives with alternate dose limits and/or land use scenarios to develop higher cleanup guidelines, or to choose alternate actions that do not require excavation. Constrain analysis to less than $75 \mathrm{mrem} / \mathrm{y}$ under residential land use, and consider qualitative ecological values. Consider impacts to groundwater and associated monitoring costs as well as the costs of maintaining institutional control. After choosing the preferred alternative, perform an ALARA analysis to see if exposures can reasonably be reduced below the identified dose limit. 


\section{GUIDANCE FOR IMPLEMENTATION}

The approach to implementing the recommended process is described in detail below. This includes steps in deriving soil cleanup guidelines, assessment of potential impacts to groundwater and specific guidance on performing net benefit analyses and ALARA assessments. Any process that includes optional pathways is difficult to describe clearly in linear text. To guide the reader through the process, the text is closely integrated with Figure 8-1. Letters in brackets in subsection headings are keyed to letters in the figure.

This process should be performed as part of the Feasibility Study review of alternate remedial options, and is intended to support the choice of a final cleanup option and associated soil cleanup guidelines. The approach suggested here provides methods to derive preliminary remedial guidelines for cleanup of radionuclides in soil, as well as methods to estimate the net benefit of alternate options (and guidelines) while factoring into the decision the level of protectiveness (i.e. dose limit and land use assumptions).

\section{Select Land Use Scenarios [A]}

The first step is to identify probable future land use(s) at the level of the Operable Unit or Area of Concern based on the BNL Future Land Use Plan (BNL, 1995; Figure 3-2). Associated exposure pathways for each land use are given in Table 1 in Appendix I. The process must be repeated for each land use considered.

\section{Derive Preliminary Remediation Cleanup Guidelines [B]}

Radionuclide-specific generic preliminary cleanup guidelines were derived using data from OU IINII. Where these are applicable, they can be used as the basis for preliminary cleanup guidelines that apply to the actual radionuclide mix. This is necessary since the residual levels of radionuclides ( $\mathrm{pCi} / \mathrm{g}$ of soil) that can remain after cleanup depends on the mix of radionuclides originally in the soil. Finally, where generic guidelines are inadequate, e.g., due to differences in the depth to ground water or other site-specific differences from the generic assumptions, OU/AOC specific guidelines must be developed.

The following subsections describe (1) the derivation of radionuclidespecific generic preliminary guidelines; (2) the application of those guidelines; (3) how to determine the applicability of those guidelines; and (4) development of OUIAOC specific guidelines where necessary. 
Figure 8-1. Proposed approach for deriving cleanup guidelines for radionuclides in soils at $B N L$.

[A]

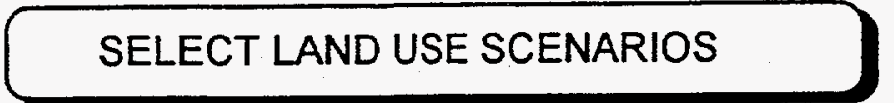

[B]

DERIVE PRELIMINARY

REMEDIATION GUIDELINES

[C]

ASSESS POTENTIAL

GROUNDWATER IMPACTS

[D]

CONDUCT QUALITATIVE NET BENEFIT ANALYSES FOR MEETING DOSE LIMIT

[H]

\section{ESTABLISH FINAL REMEDIATION} GUIDELINES

DEVELOP

ALTERNATIVE SCENARIOS, GUIDELINES AND REMEDIAL OPTIONS

[l] 


\section{Radionuclide-Specific Generic Preliminary Guidelines}

Because mixtures of radionuclides in soil and future land uses vary across the site (Future Land Use Plan; BNL, 1995), no single set of cleanup guidelines in units of $\mathrm{pCi} / \mathrm{g}$ can be derived for BNL. A set of maximum cleanup guidelines can be derived on a radionuclide specific basis for all radionuclides detected at above background concentrations at BNL.

Generic preliminary guidelines were derived for four proposed land uses for the site: industrial/commercial, open space, recreational and residential. For each land use type, guidelines were developed under three assumptions regarding the time frame for release of the site to the proposed land use: current release, 50 years in the future and 100 years in the future. The generic guidelines are based on average physical site conditions and source term assumptions. These guidelines are single-radionuclide guidelines, which represent, for each radionuclide listed, the concentration associated with a dose rate of $15 \mathrm{mrem} / \mathrm{y}$ under each proposed land use or $75 \mathrm{mrem} / \mathrm{y}$ for a suburban residential use. Values for these preliminary generic guidelines are given in Tables 8-1 through 8-3. Because DOE has no plans for closure of the site, the suggested approach is to use preliminary guidelines for release of the site 50 years in the future.

These guidelines must be modified to give residual concentrations for each radionuclide in a mixture by reducing the maximum concentration given in the Tables by the ratio of the total activity in soil represented by each radionuclide. In RESRAD documentation, this value is referred to as the mixture sum (Yu et al., 1993). Guidelines derived this way are conservative, because they assume that the maximum dose as calculated by the RESRAD model will occur at the same time for all radionuclides in the mixture, when in fact different radionuclides will reach their maximum dose rate at different times. This mixture sum should include radium, unless DOE determines that the $5.0 \mathrm{pCi} / \mathrm{g}$ standard for radium (DOE Order 5400.5) should be treated independently of the 15 $\mathrm{mrem} / \mathrm{y}$ dose limit in establishing remediation guidelines. In the latter case, post-remediation surveys and analysis should assure that future people onsite are protected.

\section{Apply Radionuclide-Specific Generic Preliminary Guidelines to Actual Radionuclide Mix}

Decide if generic preliminary guidelines are appropriate in terms of assumptions concerning site hydrogeological characteristics and the size of the contaminated zone. If generic preliminary guidelines are appropriate, calculate the ratio of the total activity represented by each radionuclide. Multiply these fractions by the maximum single-radionuclide generic guidelines for each radionuclide given in Tables 8-1 through 8-3 for the appropriate period of institutional control to get preliminary guidelines for this OUIAOC. 


\begin{tabular}{|l|c|c|c|c|}
\hline \multicolumn{5}{|c|}{ An Example Calculation } \\
\hline Radionuclide & $\begin{array}{c}\text { Existing } \\
\text { concentration } \\
\text { (pCi/g) }\end{array}$ & $\begin{array}{c}\text { Ratio of total } \\
\text { existing activity }\end{array}$ & $\begin{array}{c}\text { RESRAD } \\
\text { cleanup } \\
\text { guideline for } \\
\text { individual } \\
\text { radionuclide } \\
(\mathrm{pCi} / \mathrm{g})^{1}\end{array}$ & $\begin{array}{c}\text { Resulting cleanup } \\
\text { guideline (pCi/g) }\end{array}$ \\
\hline Cesium-137 & 50 & $50 / 70=0.714$ & 23 & $23 \times 0.714=16.4$ \\
\hline Strontium-90 & 20 & $20 / 70=0.286$ & 75 & $75 \times 0.286=21.5$ \\
\hline
\end{tabular}

1 guidelines in example are for release of the site in 50 years assuming suburban residential land use.

\section{Applicability of Generic Preliminary Guidelines}

These generic preliminary guidelines are appropriate when:

- the generic hydrological and physical site conditions used in the model are appropriate to the specific OUIAOC;

- the generic assumptions concerning the size and depth of the source term and model boundary conditions are appropriate to the specific OU/AOC.

When these conditions are not met, OU/AOC specific preliminary guidelines must be derived.

\section{Create OU/AOC Specific Preliminary Guidelines if Necessary}

If generic preliminary guidelines are not appropriate for this OUIAOC, derive OUIAOC specific guidelines. Run the RESRAD model for the appropriate land use and exposure parameters as given in Appendix I, Table 2 for the mixture of radionuclides in the OU/AOC under assessment. Modify assumptions concerning the source term, boundary conditions or hydrogeological parameters as needed (parameters marked "SITE SPECIFIC"). Constrain to $15 \mathrm{mrem} / \mathrm{yr}$. Also run for suburban residential use (exposure parameters in Appendix II) for $75 \mathrm{mrem} / \mathrm{yr}$. The most restrictive concentrations of these two results are the preliminary guidelines.

\section{Assess Potential Impact to Groundwater [C]}

Table 8-4 gives the maximum predicted concentrations in ground water beneath the waste site in units of $\mathrm{pCi} / \mathrm{L}$ per $\mathrm{pCi} / \mathrm{g}$ of radionuclide in soil. For the preliminary guidelines derived above, calculate the maximum worst-case concentration in groundwater and the associated doses (concentrations per $\mathrm{pCi} / \mathrm{g}$ and dose conversion factors in Table 8-4; conversion factors are from EPA (1991c) -- requlatory agencies may require use of more conservative converion factoprs in EPA (1976). Compare these estimates to the USEPA and NYS MCLs given in Table 8-5. 
These concentrations are based on the generic site assumptions used to derive the generic preliminary guidelines for BNL. If necessary, develop sitespecific predictions by running RESRAD with site specific parameters replacing those marked "SITE SPECIFIC" (Appendix I).

If this initial screening analysis suggests a potential for MCLs to be exceeded, perform a more accurate assessment using site specific input data and ground water models that have been used at BNL. If these analyses also suggest a reasonable potential for exceeding MCLs, BNL should assess the net benefit associated with meeting MCLs, determine if meeting MCLs is practicable, and consider institutional controls that will eliminate the groundwater pathway. This decision should be made as part of the net benefit analysis performed on each set of preliminary guidelines in steps [D] and $[E]$.

The collective dose to future onsite receptors from contaminants in groundwater will be included in the net benefit analysis performed in the next step.

\section{Conduct Net benefit Analysis [D]}

The following sections present the method suggested for applying net benefit analysis to identified preliminary remedial guidelines and alternatives requiring excavation of soil. This approach develops quantitative estimates of costs and benefits when possible, and combines these estimates with qualitative assessments in a qualitative determination of the cost-effectiveness associated with remediation to the preliminary guidelines (based on $15 \mathrm{mrem} / \mathrm{y}$ ). Other more prescriptive methods are available (as described in Section 7). Appendix III gives guidance on use of the RADS software developed at BNL. Many of the values input to this system can be derived as described in the following sections. The major difference between the two approaches is that the RDS program requires that numerical values be assumed to describe the worth of a life saved or some ecological values ( $\$$ per acre of wetland).

First, the required data must be assembled. Each of the parameters is described, appropriate units are discussed, and the method of derivation explained. In the next section, the qualitative approach to using these data in net benefit analysis is described.

\section{Cost of Cleanup}

This is part of the cost in the net benefit equation. It can be estimated in a relatively straightforward manner. Estimate the costs associated with meeting the proposed cleanup guidelines for the identified alternatives. Develop estimates of soil concentration with depth, soil volumes for excavation, and capital and labor costs. Estimate labor and laboratory costs associated with soil excavation, backfill and terrain restoration and cleanup verification. Include the costs of transportation and burial or storage. These costs are generated as part of the Feasibility Study assessment of alternatives. 


\section{Cost of Long-Term Monitoring and Maintenance of Institutional Control}

This is part of the cost in the net benefit equation. Estimate the costs associated with long-term groundwater monitoring and maintenance of institutional control that will be required for the identified remedial alternatives. These costs are generated as part of the Feasibility Study assessment of alternatives.

Impacts to Remediation Workers

This is part of the cost in the net benefit equation. It refers to health effects to workers during the cleanup process. These include industrial accidents, cancers from exposure to radiation in the cleanup operation, and other occupational diseases. These effects are estimated quantitatively.

Occupational accidents occur in the present and are immediately identifiable. Historical statistics are available for projection. Accidents can occur during soil excavation, backfill and terrain restoration operations, volume reduction and cleanup verification. Occupational diseases are delayed, perhaps by decades, and are more difficult to link to the cleanup. Disease due to radiation exposure can be estimated from estimated exposure levels using a well accepted linear dose-response relationship of $5 \times 10^{-4}$ deaths per personrem (ICRP, 1991).

Calculate risks to workers from during remediation as described in EPA (1994) and using average case parameters from EPA (1994) as given in Table 8-6:

Fatalities to Remediation Workers from Accidents:

Number of Fatalities $=$ Labor Rate $\left(\mathrm{hrs} / \mathrm{m}^{3}\right.$ soil $) \times$

Fatality Rate (fatalities/ $\mathrm{hr}$ ) $\times$ Soil Volume $\left(\mathrm{m}^{3}\right)$

Fatalities to Remediation Workers from Exposure to Radiation:

Number of Fatalities $=$ Number of workers exposed $x$

average estimated exposure level (total mrem over entire remediation period) $\times$ dose response function $\left(5 \times 10^{-4}\right.$ deaths/person-rem)

When data area available, these equations can be applied to workers in specific job categories separately (Travis et al., 1993; Hoskin et al., 1994).

\section{Transportation Risks}

This is part of the cost in the net benefit equation. Transportation risks are accidents associated with transportation of the material offsite. These risks include traffic accident fatalities to transportation workers as well as to the general public. Calculate this risk using parameters from Table 8-6 and site specific data on distance and use of truck or rail as: 


\section{Fatalities From Truck and Rail Transportation:}

Number of Fatalities $=$ Distance $(\mathrm{km}) \times$ Volume per Trip $\left(\mathrm{m}^{3} /\right.$ trip $) \times$

Fatalities Rate (fatalities $/ \mathrm{km}$ ) $\times$ Number of Trips

Impacts to Offsite Population During Remediation

This is part of the cost in the net benefit equation. The offsite impact to human health during remediation is associated with the potential for transport of soil contamination in air to offsite receptors. EPA (1995a) found this to be a negligible risk and it will not be considered here.

Ecological Impacts

This is part of the cost in the net benefit equation. Cleanup operations can disrupt the natural ecology of an area. Damage depends on the prior state of the area affected and is generally related to the areal extent of disruption rather than the amount of dirt moved. Some effects may be dichotomous rather than incremental. For example, Tiger Salamander habitat may be destroyed or not. The core area of the Pine Barrens may be encroached upon incrementally, but the impact will be greater than the sum of the increments and a point can be reached where the damage is such that it is not recoverable.

Environmental damage takes place in the present, although current damage may lead to additional impacts in the future. For relatively small areas on the BNL site, given adequate protection, the environment will recover over time.

There are approaches available to quantify ecological effects (EPA, $1992 \mathrm{~b}$; Suter, 1993) but in this case it is recommended that the impacts be described qualitatively, supplemented by some quantitative information (e.g. number of acres affected).

Describe the ecology of the area that will be affected by the cleanup, and estimate the areal extent of soil excavation and other disruptions. Determine if there are threatened or endangered species in the area; if there are any wetlands involved, and if the area is located in the Pine Barrens Core Preservation area. Describe potential effects and length of time anticipated for recovery.

\section{Risk Averted to Future Receptors}

This is the benefit in the net benefit equation. It refers to cancers to future receptors (residents, workers or users of a park depending on the land use) that are averted by cleaning up the site compared to cancers that would have occurred were the same land use pattern to develop with no cleanup.

These effects will not begin until 20 or more years following the release of the site, which may be 50 to 100 years in the future. The risk will then continue long into the future. Since the maximum incremental dose is restricted to less than half background, these are hypothetical, statistically projected effects that can never be identified. 
These risks should be calculated for the average exposure case and not for the RME used in establishing soil cleanup guidelines (EPA, 1994). The product of the number of people exposed, the average level of exposure, and the dose-response function gives the projected health impact. Because the area of soil contaminated at BNL is relatively small compared to the total area planned for each future land use (Table 8-7), average exposures should be reduced by the percentage of the total land use type planned for future use at BNL represented by the contaminated area.

To calculate this parameter, run RESRAD for the base case (no cleanup) and for the preliminary cleanup guidelines using the RESRAD parameters given for the average exposure case (Appendix I, Table 4), and the exposure pathways in Appendix I, Table 1 . If site specific preliminary guidelines were developed for this OU/AOC, use appropriate modifications for source term and physical parameters.

Run the assessment for three time periods: 100 years, 200 years and 1,000 years. RESRAD provides the dose-to-source ratio (DSR) for each radionuclide.

Estimate the population exposed using values in Table 8-7.

Radiation-induced cancer incidence is generally assumed to be linear with dose. Calculate the total expected number of cancers averted for the planned future land use for each time period $(100,200$ and 1,000 years) as the number of people exposed times the incremental dose (the dose without cleanup minus the expected dose following cleanup) times the dose-response coefficient. Note that the dose without cleanup must be summed across all radionuclides while the dose after cleanup is the overall goal. In algebraic terms, this calculation is:

$$
\text { Expected cancer fatalities }=P \times\left\{\left[\Sigma_{i}\left(C_{i} \times D S R_{i, t \min }\right)\right]-G\right\} \times D
$$

Where:

$\mathrm{C}_{\mathrm{i}}=$ concentration of radionuclide $\mathrm{i}$ in soil before cleanup (pCi/g)

$\mathrm{DSR}_{\mathrm{i}, \text { tmin }}=$ dose to source ratio for radionuclide $\mathrm{i}$ in mrem/y per $\mathrm{pCi} / \mathrm{g}$

$G=$ the soil cleanup goal (the total dose in mrem/y expected following

cleanup)

$P=$ number of people exposed

$D=$ dose-response function $\left(5 \times 10^{-4}\right.$ fatal cancers per person-rem $)$

Other Qualitative Impacts

Some land uses are more "valuable" to the community than others. This is difficult to address since some segments of the community may value land uses differently. For example, real estate developers may value residential use while nearby residents may value open space. Some land uses are more in keeping with existing development trends. These have the advantage that if they are 
planned for, they are more likely to develop. For example, there is little industry in the area. If plans called for industrial development, there is a high likelihood that they would not come to fruition. On the other hand, were the site designated as parkland, it would be difficult to convert it to development.

These qualitative factors may be described and should be taken into consideration in the net benefit analysis.

\section{Doing the Net benefit Calculation [E]}

Although it uses some numerical estimates, this step is not intended as a quantitative exercise. Its purpose is to determine if the identified preliminary guidelines can be met in a satisfactory way. It is not a mechanical calculation for several reasons: not all parameters can be quantified, those that are quantified have different units and time frames of impact, people may view the parameters differently, there may be several remedial options available, and there is uncertainty in the numbers and in the future.

Consider the three data components from step [D]. Are costs excessive? Are risk to workers or transportation risks excessive? Are potential environmental impacts of the necessary cleanup excessive?

The benefits should be greater than the costs. In algebraic terms:

(future receptor risk averted) - (remedial worker risk caused) - (transportation related deaths caused) - (ecological damage caused) - (cost) $>0$

While to a mathematician this may seem impossible to solve, people do solve problems of this kind every day. How should it be done in this case?

A risk committee, composed of various stakeholders (including representatives from DOE, BNL, regulatory agencies and one or more publics) decide individually if the inequality is satisfied. Some may choose to convert each parameter into a dollar value and do the arithmetic. Some may balance the parameters more directly: is this much environmental damage worth the health benefit? Some may simply have upper limits to one or more of the costs that they do not believe should be exceeded, or lower limits on the health risk avoided. The "voting rules" for the committee should be established a priori by those ultimately responsible for the decision, e.g., DOE, EPA, and DEC.

If the preliminary guidelines for a particular remedial alternative are found to cause tolerable environmental and worker risk for the costs and benefits in terms of cancers averted, then the guidelines are accepted. If they are not accepted, one must move into the optimization process described below.

\section{Develop Alternative Scenarios, Dose Limits and Remedies [F]}

If it is decided that either costs, risks to workers, transportation risks, or potential environmental damage are not within acceptable limits, then it is necessary to re-think the process to find alternative solutions. This is a phase that is often called "stepping out of the box." The first step is to examine 
possible alternate guidelines or remedial options in an iterative qualitative optimization analysis.

If preliminary guidelines were derived using generic site parameters, use RESRAD to derive OU/AOC specific guidelines as described in Step [B]. If these values are significantly different than the first set of preliminary guidelines, return to steps $[D]$ and $[E]$ and perform another qualitative cost benefit analysis to see if alternate scenarios and dose limits must be considered.

Develop alternate scenarios, including possible use of engineered barriers and dose limits for consideration. Consider only dose limits less than or equal to $75 \mathrm{mrem} / \mathrm{yr}$.

If the EPA proposed regulatory limit of $75 \mathrm{mrem} / \mathrm{y}$ to a resident in case of failure of institutional controls is controlling, consider the reasonableness of this assumption and alternative assumptions under a loss of institutional control.

If meeting MCLs in groundwater is controlling, consider whether meeting these are "impracticable" and consider appropriate institutional controls to eliminate this exposure pathway.

Run the RESRAD model, using the exposure parameters given in Appendix I, Table 2, for alternate scenarios and dose limits. Perform cost and risk analysis using the simple assumptions and models described below.

Include a qualitative consideration of the ecological impacts avoided for the alternative scenarios and dose limits.

\section{Conduct Net Benefit Analyses to Select Cleanup Alternative [G]}

The best solution is derived iteratively with the development of alternative scenarios, dose limits and alternatives (above). It is a decision process similar to that described in the section "Doing the Net benefit Analysis [E]", above. Potential alternative actions are developed and the "best" or most tolerable solution selected.

A large variety of options could be considered. Consider six alternate land use scenarios, with two or three modifying options for each (altering the physical character of the site) and several alternate dose limits. This could lead to over 50 different options.

Evaluation of this many options raises the problem of increasing the cost of evaluating choices to support an intelligent decision. The initial stage of the optimization assessment is to identify a limited number of reasonable alternate land use/dose limit scenarios for further consideration.

Not all land use scenarios will be suitable for the entire site. The land use plan calls for several different land use types in different areas of the site. Many areas on site, however, are suitable for more than one potential land use

Additional options for some OU/AOCs may be generated by modifying scenarios to include active controls, e.g. fencing and restricting access to areas 
of high contamination. An additional option that may be reasonable for some OUs and AOCs and not for others is to assume that DOE will maintain institutional control of the area for 100 years.

The next stage is to develop the cost and risk information associated with each scenario, and perform a net benefit analysis as described in the previous section. This involves running RESRAD to estimate soil concentrations and individual risks, and the additional calculations needed to estimate future receptor risks, worker risks and potential impacts to ecological values.

The most difficult part of the net benefit analysis may be determining the cost of cleanup for each case. This involves optimizing the technology to be used, which will vary depending on the existing conditions in each OU/AOC, the variation in those conditions, and the soil cleanup criteria for the case. The technologies that realistically might be used, however, are limited. A little thought should allow rough estimates of cost to be scaled from more exact calculations on a few cases.

Once the values for each major parameter (population risk, worker risk, population risk and cost) are determined, many options will be obviously inferior to other options and can be immediately removed from consideration, leaving only a few options that allow a clear choice.

The choice between options should be a joint decision between BNL, DOE and Federal and State regulators, with input from the public and other stakeholders. Clear presentations of the costs and risks (both quantitative and qualitative) associated with each option is needed to support the qualitative cost and risk-based decision making required in this final step.

The resulting "optimal" strategy is clearly not a strategy that the participants would consider ideal. It is the best strategy they can find given the conflict of costs and risks that are associated with either more or less cleanup.

This method suggests performing a limited number of sensitivity analysis for the two or three preferred alternatives, where costs are varied within a reasonable range to see if a wrong decision could be made if costs vary from what was assumed in the initial analysis.

\section{Establish Final Remediation Guidelines [H]}

There are two routes by which one reaches this step. First, if the net benefit analysis decision $[E]$ is that the balance of costs and risks are acceptable, then the preliminary guidelines become the final soil cleanup goals.

The second route results from the net benefit analysis decision $[E]$ finding that the balance of costs and risks are not acceptable, i.e., that one or more (or the combination) of the costs are too high. In that case alternative strategies are developed [F] and an optimal strategy determined [G]. The optimal strategy then defines the final soil cleanup goals and remedial option combination. 
Even $A O C$-specific guidelines are generalized, since they must apply to a substantial area. In the implementation of the cleanup process itself, considerable variation may exist in the level of contamination. These guidelines are to be applied to the average concentration in soil within an area of at least $100 \mathrm{~m}^{2}$ and to a depth of $15 \mathrm{~cm}$ (Yu et al., 1993). For small isolated areas of contamination, "hot spots", the allowable concentrations that can remain after remediation may be higher. Table 8-8 gives guidelines for determining allowable residual concentrations in these hot spots from the RESRAD documentation (Yu et al., 1993).

\section{Conduct ALARA Assessment During the Design Phase [1]}

The analysis involves calculating the volumes of soil, which is a surrogate for costs, that will require remediation over a range of remediation goals which is a surrogate for radiological risk. The volumes / costs from these estimates will typically increase dramatically below a certain concentration / risk range. Since the ALARA level is the point where the ratio of the differential cost of protection and the differential risk is a minimum the final remediation goal that is ALARA can be selected. Because the dose limit is so low $(15 \mathrm{mrem} / \mathrm{y})$ it is likely that the guidelines cannot be cost-effectively reduced.

\section{ALARA Documentation After Remediation [J]}

After remediation is complete, document that residual exposures are ALARA. Prior to and after the completion of the final remedy the performance against remedial objectives identified in the Feasibility Study (including the final remedial guidelines for residual radioactivity in soil) should be monitored and documented. The documentation should provide a comprehensive record of the radiological conditions following the termination of the facility's operation and the final status after completion of decommissioning and environmental restoration activities. This should include the following:

1) Radiological analysis results for soil and groundwater samples taken during site characterization, remedial investigation, design and construction, as well as the final status survey and any confirmatory surveys.

2) Background concentrations in soil and groundwater on the site.

3) Groundwater and soil final remedial goals established for the site.

4) Measured maximum and average remediation worker dose, and collective dose for remediation.

5) Estimated maximum and average dose to a member of the public, and collective dose to the public resulting from remediation.

6) Any damage to the environment resulting from remediation, including actions taken and their efficacy for any population of wildlife that had to be relocated. 
Table 8-1. Assuming current release of site: generic single-radionuclide preliminary cleanup guidelines $(\mathrm{pCi} / \mathrm{g}$ ) based on $15 \mathrm{mrem} / \mathrm{y}$ dose limit for four land scenarios and $75 \mathrm{mrem} / \mathrm{y}$ for a suburban resident (guidelines less restrictive than the $75 \mathrm{mrem} / \mathrm{y}$ residential guidelines are shaded).

\begin{tabular}{|c|c|c|c|c|c|}
\hline Radionuclide & $\begin{array}{c}\text { Commerciall } \\
\text { Industrial }\end{array}$ & $\begin{array}{l}\text { Suburban } \\
\text { Residential }\end{array}$ & $\begin{array}{l}\text { Undeveloped } \\
\text { Open Space }\end{array}$ & $\begin{array}{c}\text { Developed } \\
\text { Recreational }\end{array}$ & $\begin{array}{l}\text { Suburban } \\
\text { Residential } \\
\text { (75 mrem/y) }\end{array}$ \\
\hline Americium-241 & 150 & 36 & (x) & x & 180 \\
\hline Cesium-137 & 21 & 7 & 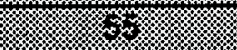 & (3) & 35 \\
\hline Cobalt-60 & $x$ & 1.5 & 4 & 38 & 7.5 \\
\hline Europium-152 & 10 & 3 & (3) & צ & 15 \\
\hline Europium-154 & 9 & 3 & Y) & (1) & 15 \\
\hline Europium-155 & 390 & 130 & 6 & (3) & 650 \\
\hline Plutonium-238 & 190 & 44 & 220 & 46 & 220 \\
\hline Plutonium-239 & 170 & 40 & 200 & 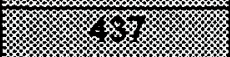 & 200 \\
\hline Plutonium-240 & 170 & 40 & 200 & x & 200 \\
\hline Radium-226* & 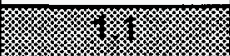 & 0.15 & 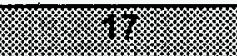 & $4 \%$ & 0.75 \\
\hline Strontium-90 & $2 \%$ & 9 & 4 & 好 & 45 \\
\hline Uranium-234 & 720 & 200 & 730 & 1) & 980 \\
\hline Uranium-235 & 84 & 28 & (6) & 6 & 140 \\
\hline Uranium-238 & 320 & 97 & 48 & 23. & 490 \\
\hline
\end{tabular}

* $5 \mathrm{pCi} / \mathrm{g}$ guideline for ${ }^{226} \mathrm{Ra}$ and ${ }^{228} \mathrm{Ra}$ may apply (DOE Order 5400.5). 
Table 8-2. Assuming release of site in 50 years: generic single-radionuclide preliminary cleanup guidelines ( $\mathrm{pCi} / \mathrm{g}$ ) based on $15 \mathrm{mrem} / \mathrm{y}$ dose limit for four land use scenarios and $75 \mathrm{mrem} / \mathrm{y}$ for a suburban resident (guidelines less restrictive than the $75 \mathrm{mrem} / \mathrm{y}$ residential guidelines are shaded).

\begin{tabular}{|c|c|c|c|c|c|}
\hline Radionuclide & $\begin{array}{c}\text { Commercial } \\
\text { /ndustrial }\end{array}$ & $\begin{array}{l}\text { Suburban } \\
\text { Residential }\end{array}$ & $\begin{array}{l}\text { Undeveloped } \\
\text { Open Space }\end{array}$ & $\begin{array}{c}\text { Developed } \\
\text { Recreational }\end{array}$ & $\begin{array}{l}\text { Suburban } \\
\text { Residential } \\
\text { (75 mrem/y) }\end{array}$ \\
\hline Americium-241 & 160 & 39 & 4 & (6) & 195 \\
\hline Cesium-137 & 70 & 23 & (3) & . & 115 \\
\hline Cobalt-60 & 3700 & 1300 & צy & 2 & 6300 \\
\hline Europium-152 & 140 & 48 & \% & (3) & 240 \\
\hline Europium-154 & 490 & 165 & 4 & 40 & 830 \\
\hline Europium-155 & $4.3 \mathrm{E} 5$ & $1.4 \mathrm{E} 5$ & \% (2) & 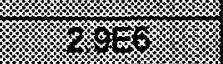 & $7.0 \mathrm{E} 5$ \\
\hline Plutonium-238 & 250 & 66 & 330 & $\sqrt[3]{3}$ & 330 \\
\hline Plutonium-239 & 170 & 40 & 200 & 48 & 200 \\
\hline Plutonium-240 & 170 & 41 & 200 & : & 200 \\
\hline Radium-226* & 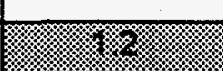 & 0.15 & 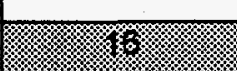 & 的 & 0.75 \\
\hline Strontium-90 & $686 \%$ & 75 & 19988 & thets & 380 \\
\hline Uranium-234 & 1200 & 350 & 1300 & (2) & 1800 \\
\hline Uranium-235 & 130 & 49 & 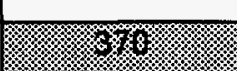 & (15. & 250 \\
\hline Uranium-238 & 510 & 175 & $(15)$ & 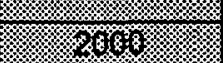 & 880 \\
\hline
\end{tabular}

* 5 pCi/g guideline for ${ }^{226} \mathrm{Ra}$ and ${ }^{228} \mathrm{Ra}$ may apply (DOE Order 5400.5 ). 
Table 8-3. Assuming release of site in 100 years: generic single-radionuclide preliminary cleanup guidelines ( $\mathrm{pCi} / \mathrm{g}$ )based on $15 \mathrm{mrem} / \mathrm{y}$ dose limit for four land use scenarios and $75 \mathrm{mrem} / \mathrm{y}$ for a suburban resident (guidelines less restrictive than the $75 \mathrm{mrem} / \mathrm{y}$ residential guidelines are shaded).

\begin{tabular}{|c|c|c|c|c|c|}
\hline Radionuclide & $\begin{array}{c}\text { Commercial } \\
\text { /Industrial }\end{array}$ & $\begin{array}{c}\text { Suburban } \\
\text { Residential }\end{array}$ & $\begin{array}{l}\text { Undeveloped } \\
\text { Open Space }\end{array}$ & $\begin{array}{c}\text { Developed } \\
\text { Recreational }\end{array}$ & $\begin{array}{c}\text { Suburban } \\
\text { Residential } \\
\text { (75 mrem/y) }\end{array}$ \\
\hline Americium-241 & 180 & 43 & 220 & 8 & 220 \\
\hline Cesium-137 & 230 & 75 & 8 & (6) & 380 \\
\hline Cobalt- 60 & $3.0 \mathrm{E} 6$ & $1.1 \mathrm{E} 6$ & \% & 的 & 6E6 \\
\hline Europium-152 & Fes. & 652 & 38 & \% & 3300 \\
\hline Europium-154 & $2.6 E 4$ & 8640 & 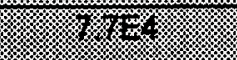 & 4.64 & $4.3 E 4$ \\
\hline Europium-155 & $4.7 E 8$ & $1.6 \mathrm{E} 8$ & 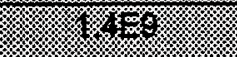 & 桨 & $8.0 E 8$ \\
\hline Plutonium-238 & 420 & 100 & 500 & (6) & 500 \\
\hline Plutonium-239 & 170 & 41 & 210 & 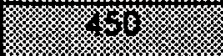 & 210 \\
\hline Plutonium-240 & 180 & 42 & 210 & 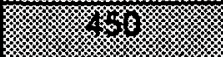 & 210 \\
\hline Radium-226* & 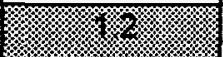 & 0.16 & 1. & , & 0.8 \\
\hline Strontium-90 & 74 & 40 & 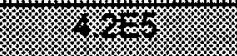 & 65 & 200 \\
\hline Uranium-234 & 1800 & 600 & 40 & 4 & 3000 \\
\hline Uranium-235 & 210 & 85 & 63 & (6) & 420 \\
\hline Uranium-238 & 810 & 320 & 89 & (3. & 1600 \\
\hline
\end{tabular}

* $5 \mathrm{pCi} / 9$ guideline for ${ }^{226} \mathrm{Ra}$ and ${ }^{228} \mathrm{Ra}$ may apply (DOE Order 5400.5). 
Table 8-4. Peak concentrations in groundwater beneath site per unit concentration in soil (time of peak concentration in years assuming generic site conditions and soil concentrations at time zero); concentration conversion factor (water ingestion, based on $2 \mathrm{Ld}$; lifetime exposure); USEPA MCLs and associated screening soil concentrations.

\begin{tabular}{|c|c|c|c|c|c|}
\hline Radionuclide & $\begin{array}{l}\text { Water:Soil } \\
\text { Ratio } \\
\text { (pCi/L per } \\
\text { pCi/g) }\end{array}$ & $\begin{array}{c}\text { Time of } \\
\text { Peak Conc } \\
\text { (y) }\end{array}$ & $\begin{array}{l}\text { Conc. Conversion } \\
\text { Factor } \\
\text { pCi/L per mrem } / y^{2}\end{array}$ & $\begin{array}{c}\text { USEPA } \\
M C L^{3} \text { (pCi/L) } \\
\text { (EPA 1991 } \\
\text { conversion } \\
\text { factors) }\end{array}$ & $\begin{array}{l}\text { Screening Soil } \\
\text { Conc. Equivalent } \\
\text { to } \mathrm{MCL} \\
\text { (pCi/g) }\end{array}$ \\
\hline Americium-241 ( $\alpha)$ & 0 & 210 & 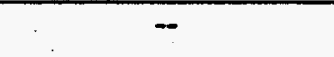 & 15 & $\mathrm{NC}$ \\
\hline Cesium-137 ( $\beta)$ & 0 & $\overline{-}$ & 30 & 119 & $\mathrm{NC}$ \\
\hline Cobalt-60 ( $\beta)$ & 0 & - & 55 & 218 & NC \\
\hline Europium-152 ( $\beta$ ) & 0 & - & 210 & 841 & NC \\
\hline Europium-154 ( $\beta$ ) & 0 & - & 143 & 573 & $\mathrm{NC}$ \\
\hline Europium-155 ( $\beta)$ & 0 & - & 898 & 3590 & $\overline{N C}$ \\
\hline Plutonium-238 ( $\alpha$ ) & 0 & 560 & - & 15 & $\mathrm{NC}$ \\
\hline Plutonium-239 ( $\alpha)$ & 0 & 725 & - & 15 & NC \\
\hline Plutonium-240 ( $\alpha)$ & 0 & 700 & - & 15 & NC \\
\hline Radium-226 ( $\alpha$ ) & $1.4 \times 10^{-4}$ & $1000^{4}$ & - & 5 & 7,143 \\
\hline Strontium-90 ( $\beta)$ & 6.8 & 70 & 10.5 & 42 & 1.2 \\
\hline Uranium-234 ( $\alpha)$ & 8.2 & 540 & - & 15 & 1.8 \\
\hline Uranium-235 ( $\alpha)$ & 8.2 & 540 & - & 15 & 1.8 \\
\hline Uranium-238 ( $\alpha$ ) & 4.1 & 849 & - & 15 & 3.7 \\
\hline
\end{tabular}

Concentration predicted by RESRAD directly under source term.

2 Calculated for beta emitters from Tables in FR 56:138; EPA (1991) Proposed National Primary Drinking Water Regulations (assumes 21/d; lifetime exposure); based on latest ICRP models and parameter values for calculating dose (ICRP 60; ICRP, 1991).

${ }^{3}$ EPA (1976), EPA-570/9-76-003; Current National Interim Primary Drinking Water Regulations: MCL for gross $\alpha$ emitters is $15 \mathrm{pCi} / \mathrm{L}$; for gross $\beta$ emitters $4 \mathrm{mrem} / \mathrm{y}$; for ${ }^{226} \mathrm{Ra}$ plus ${ }^{228} \mathrm{Ra} 5 \mathrm{pCi} / \mathrm{L}$. Concentrations of beta emitters associated with $4 \mathrm{mrem} / \mathrm{y}$ calculated from new ICRP parameters as given in Proposed Drinking Water Standards (EPA, 1991); concentrations calculated based on factors in EPA (1976) are smaller -- see table 6-3.

${ }^{4}$ Radium concentrations are small $\left(1.4 \times 10^{-4} \mathrm{pCi} / \mathrm{L}\right)$ but do not reach a peak in 1,000 years. NC - Radionuclide not predicted to migrate to groundwater, minimum guideline not calculated. 
Table 8-5. USEPA and New York State MCLS.

\begin{tabular}{|l|l|l|l|}
\hline Radionuclide & $\begin{array}{l}\text { USEPA } \\
\text { (current) }^{1}\end{array}$ & $\begin{array}{l}\text { USEPA } \\
\text { (proposed) }^{2}\end{array}$ & $\begin{array}{l}\text { NYS (Potable } \\
\text { Groundwater) }^{3}\end{array}$ \\
\hline Total dose & - & - & $4 \mathrm{mrem} / \mathrm{y}$ \\
\hline Gross $\alpha$ emitters & $15 \mathrm{pCi} / \mathrm{L}$ & $15 \mathrm{pCi} / \mathrm{L}^{4}$ & $15 \mathrm{pCi} / \mathrm{L}^{6}$ \\
\hline $\begin{array}{l}\text { Gross } \beta(\beta \text { and } \gamma \\
\text { emitters) }\end{array}$ & $4 \mathrm{mrem} / \mathrm{y}$ & $\begin{array}{l}4 \mathrm{mrem} / \mathrm{y} \\
50 \mathrm{pCi} / \mathrm{L}^{5}\end{array}$ & $1,000 \mathrm{pCi} / \mathrm{L}^{7}$ \\
\hline${ }^{226} \mathrm{Ra}$ & - & $20 \mathrm{pCi} / \mathrm{L}$ & $3 \mathrm{pCi} / \mathrm{L}$ \\
\hline${ }^{228} \mathrm{Ra}$ & - & $20 \mathrm{pCi} / \mathrm{L}$ & - \\
\hline${ }^{226} \mathrm{Ra}+{ }^{228} \mathrm{Ra}$ & $5 \mathrm{pCi} / \mathrm{L}$ & - & $5 \mathrm{pCi} / \mathrm{L}$ \\
\hline${ }^{90} \mathrm{Sr}$ & $8 \mathrm{pCi} / \mathrm{L}^{8}$ & $42 \mathrm{pCi} / \mathrm{L}^{8}$ & $8 \mathrm{pCi} / \mathrm{L}$ \\
\hline$U$ & - & $30 \mathrm{pCi} / \mathrm{L}(20 \mu \mathrm{g} / \mathrm{l})$ & - \\
\hline Tritium & $20,000^{8}$ & $60,900^{8}$ & 20,000 \\
\hline
\end{tabular}

1976 National Interim Primary Drinking Water Regulations (EPA, 1976; 40 CFR 141.15)

${ }^{2}$ Proposed National Primary Drinking Water Regulations: Radionuclides (EPA, 1991; FR:

56:138)

${ }^{3}$ New York State Water Quality Regulations Title 6, Chapter X, Parts 700-705

${ }^{4}$ adjusted gross alpha emitters (excluding ${ }^{226} \mathrm{Ra},{ }^{222} \mathrm{Rn}$ and $U$ )

${ }^{5}$ presumptive screen for compliance with the MCL of $4 \mathrm{mrem} / \mathrm{y}$

${ }^{6}$ excluding radon and uranium

${ }^{7}$ excluding ${ }^{90} \mathrm{Sr}$ and alpha emitters

${ }^{8}$ not specifically identified as an MCL, but commonly treated as such, listed in EPA (1976) and EPA (1991) as equivalent to $4 \mathrm{mrem} / \mathrm{yr}$. 
Table 8-6. Input parameters for net benefit calculations (EPA, 1995b).

\begin{tabular}{|l|l|}
\hline \multicolumn{1}{|c|}{ Parameter } & \multicolumn{1}{|c|}{ Value } \\
\hline Labor Rates & \\
\hline soil excavation & $0.051\left(\mathrm{hrs} / \mathrm{m}^{3}\right)$ \\
\hline backfilling and terrain restoration & $0.017\left(\mathrm{hrs} / \mathrm{m}^{3}\right)$ \\
\hline volume reduction & $0.229\left(\mathrm{hrs} / \mathrm{m}^{3}\right)$ \\
\hline Transportation Volumes & \\
\hline transportation by truck & $12.58\left(\mathrm{~m}^{3} / \mathrm{trip}\right)$ \\
\hline transportation by rail & $3,551\left(\mathrm{~m}^{3} / \mathrm{trip}\right)$ \\
\hline Fatality Rates (fatalities per labor hour) & \\
\hline soil excavation & $1 \times 10^{-7}$ \\
\hline backfilling and restoration & $1.38 \times 10^{-7}$ \\
\hline volume reduction & $5 \times 10^{-8}$ \\
\hline truck transportation & $3.1 \times 10^{-9}$ \\
\hline rail transportation & $4.8 \times 10^{-8}$ \\
\hline
\end{tabular}


Table 8-7. Area planned for future land uses at BNL and assumed population density of number of visitors.

\begin{tabular}{|l|l|l|l|l|}
\hline & $\begin{array}{l}\text { Industrial/ } \\
\text { Commercial }\end{array}$ & $\begin{array}{l}\text { Suburban } \\
\text { Residential }\end{array}$ & Open Space & Recreational \\
\hline Area planned $\left(\mathrm{km}^{2}\right)$ & 4.5 & 0.9 & 14.6 & 1.4 \\
\hline $\begin{array}{l}\text { Population density } \\
\left.\text { (people } / \mathrm{km}^{2}\right)\end{array}$ & 1400 & 1000 & 1.6 & 500 \\
\hline
\end{tabular}

Table 8-8. Values for hot spot multiplication factors (from Yu et al., 1993).

\begin{tabular}{|c|c|}
\hline Hot Spot Area & Factor (multiple of authorized limit) \\
\hline$<1 \mathrm{~m}^{2}$ & $10^{*}$ \\
\hline $1-<3 \mathrm{~m}^{2}$ & 6 \\
\hline $3-<10 \mathrm{~m}^{2}$ & 3 \\
\hline $10-25 \mathrm{~m}^{2}$ & 2 \\
\hline
\end{tabular}

* areas $<1 \mathrm{~m}^{2}$ are averaged over a $1 \mathrm{~m}^{2}$ area, average shall not exceed 10 times the authorized limit. 


\section{IMPLEMENTATION}

The approach proposed here should be performed as part of the Feasibility Study (FS) phase of a CERCLA investigation when alternate remedies are identified and evaluated, and carried into the final cleanup stage when proposed ALARA assessments are done. The detailed net benefit analyses recommended here are meant for application in the detailed analysis of alternatives done in the FS, but a more qualitative assessment could also be used in the initial screening of alternatives. A calculation of the net benefit for each remedial alternative should be done to help choose among alternatives.

An analysis of the net benefits associated with excavation of all contaminated soils above commercial/industrial guidelines at the HWMF found high costs and minimal benefits. BNL's proposed plan for remediation of radiologically contaminated soils is to:

1) Excavate or vitrify in-place only highly contaminated soils at HWMF. Cap area that exceeds the commercial/industrial cleanup level for Cs-137.

2) The level to determine excavation will be determined using failure analysis of the cap and assuming suburban residential use after 50 years $(75 \mathrm{mrem}$ dose limit).

3) Excavate Cs-137 and Sr-90 contaminated soils in other places onsite to residential guidelines. Consolidate excavated soils under the capped area at HWMF.

4) Excavate and dispose of soils at Building 650 (various radionuclides, with higher contamination levels than other soils) to residential cleanup guideline.

Recommended soil remediation guidelines at BNL were based on an exposure limit to future residents or workers of $15 \mathrm{mrem} / \mathrm{y}$ after 50-years of institutional control. For most soils on the BNL site, Cs-137 is the dominant radionuclide. Remediation guidelines have thus been based on $\mathrm{Cs}-137$. For the Building 650 sump in OU IV, however, a broad mix of radionuclides exists. Individual remediation guidelines were developed for each radionuclide. Remediation criteria will be based on the weighted sum of the radionuclides. DOE may decide, consistent with DOE Order 5400.5 , to treat radium separately and use the $5 \mathrm{pCi} / \mathrm{g}$ guideline. 


\section{REFERENCES}

Baum, J., 1994, Value of Public Health and Safety Actions and Radiation Dose Avoided, prepared for the U.S. Nuclear Regulatory Commission by Brookhaven National Laboratory, Upton, NY, NUREG/CR-6212, BNLNUREG-52413.

BNL, 1995, Future Land Use Plan, Brookhaven National Laboratory, Upton, NY, BNL-62130.

BNL, 1996, Brookhaven National Laboratory, Operable Unit IV, Draft Record of Decision, January 19, 1996, Office of Environmental Restoration, Brookhaven National Laboratory; Brookhaven Area Office, U.S. Department of Energy, Upton, New York.

Calabrese et al., 1989. "How Much Soil do Young Children Ingest? - An Epidemiological Study", Regulatory Toxicology and Pharmacology 10:123137.

Central Pine Barrens Joint Planning and Policy Commission, 1995, Central Pine Barrens Comprehensive Land Use Plan, Volume 2: Existing Conditions, Central Pine Barrens Joint Planning Commission, Great River, New York.

de Planque, 1995, "In Search of .....Background", Radiation Protection Management, Volume 12, No. 3 pp. 23-32.

EPA, 1976, National Interim Primary Drinking Water Regulations., EPA-570/9-76003, United States Environmental Protection Agency, Washington, D.C.

EPA, 1989a, Risk Assessment Guidance for Superfund Vol. 1: Human Health Evaluation Manual (Part A), U.S. Environmental Protection Agency, Washington, DC, EPA 540/1-89/002.

EPA, 1989b, Exposure Factors Handbook. Office of Health and Environmental Assessment. U.S. Environmental Protection Agency, Washington, DC. EPAV600/8-89/043.

EPA, 1991a, Risk Assessment Guidance for Superfund (RAGS) Human Health Evaluation Manual, Part B - Development of Risk-Based Preliminary Remediation Guidelines. U.S. Environmental Protection Agency, Washington, DC. OSWER Directive 9285.7-01B.

EPA, 1991b, Role of the Baseline Risk Assessment in Superfund Remedy Selection Decisions, Memorandum from D. Clay, Assistant Administrator, April 22, 1991, OSWER Directive 9355.0-30, United States Environmental Protection Agency.

EPA, 1991c, National Primary Drinking Water Regulations; Radionuclides, Notice of Proposed Rulemaking, United States Environmental Protection Agency, Federal Register Vol 56:138, Washington, D.C. 
EPA, 1992a, Dermal Exposure Assessment: Principles and Applications, Office of Health and Environmental Assessment, U.S. Environmental Protection Agency, Washington, DC. EPA600/8-91/011b.

EPA. 1992b. Framework for Ecological Risk Assessment Office of Research and Development, U.S. Environmental Protection Agency, Washington, D.C. EPAV30/R-92/001.

EPA, 1993a, Radon Reduction Techniques for Existing Detached Homes, United States Environmental Protection Agency, U.S. Environmental Protection Agency, Washington, D.C. EPA625/R-931011.

EPA, 1993b, Remedy Selection at Superfund Sites with Radiation Contamination, 1985-1991, Volume I, by S. Cohen \& Associates, McLean, Virginia, for the U.S. Environmental Protection Agency, Washington, D.C.

EPA, 1994, EPA Radiation Site Cleanup Regulation Technical Support Document for the Development of Radiation Soil Cleanup Guidelines, Review Draft, September 1994, Office of Radiation and Indoor Air, United States Environmental Protection Agency, Washington, D.C.

EPA, 1995a, Radiation Site Cleanup Regulation 40 CFR 196 (preliminary staff working draft) published in 58 FR 54474, U.S. Environmental Protection Agency, Washington, DC.

EPA, 1995b, Draft Regulatory Impact Analysis Radiation Site Cleanup Regulation Volume I, Review Summary (preliminary staff working draft) published in 58 FR 54474, U.S. Environmental Protection Agency, Washington, DC.

Federal Register, 1991, Environmental Protection Agency, National Primary Drinking Water Regulations; Radionuclides, 40 CFR Parts 141,142, 56:138:33050.

Grisinger, J.E. and Marlia, J.C. 1994, "Development and Application of Risk Analysis Methods to Stationary Sources of Carcinogenic Emissions for Regulatory Purposes by the South Coast Air Quality District," Air \& Waste 44: 145-152.

Hogg, M.L. 1995, Site-Specific Exposure Scenarios - Their Use in Rocky Flats Environmental Technology Site (RFETS) Risk Assessment and Implications for Remedial Activities, WM'95, Tucson, AZ.

Hoskin, A.F., J. P. Leigh and T.W. Planel, 1994, "Estimated Risk of Occupational Fatalities Associated with Hazardous Waste Site Remediation", Risk Analysis 14:6: 1101-1117.

ICRP, 1959, Report of Committee 2 on Permissible Dose for Internal Radiation, ICRP Publication 2, Pergamon Press, Oxford. 
ICRP, 1977, Recommendations of the International Commission on Radiological Protection, International Commission on Radiological Protection, ICRP Publication 26, Pergamon Press, Oxford.

ICRP, 1979, Limits on Intake of Radionuclides by Workers, International Commission on Radiological Protection, ICRP Publication 30, Part 1, Vol. 2, Pergamon Press, Oxford.

ICRP, 1983, Cost-Benefit Analysis in the Optimization of Radiation Protection, International Commission on Radiological Protection, ICRP Publication 37, Pergamon Press, Oxford.

ICRP, 1989, Optimization and Decision-Making in Radiological Protection, International Commission on Radiological Protection, ICRP Publication 55, Pergamon Press, Oxford.

ICRP, 1991, "1990 Recommendations of the International Commission on Radiological Protection", Publication 60, Annals of the ICRP, 21:1-3, Pergamon Press, Oxford.

Naidu, J.R., and R.A. Royce, eds., 1994, Site Environmental Report for Calendar Year 1993, Brookhaven National Laboratory, Upton, New York, BNL52432.

NBS, 1963, Maximum Permissible Body Burdens and Maximum Permissible Concentrations of Radionuclides in Air and in Water for Occupational Exposure, U.S. Department of Commerce, National Bureau of Standards, Handbook 69.

NCRP, 1993, Limitation of Exposure to lonizing Radiation, National Council on Radiation Protection and Measurements, NCRP Report No. 116, Bethesda, MD.

NYS, 1993. Cleanup Guidelines for Soils Contaminated with Radioactive Materials, Technical Administrative Guidance Memorandum No. 4003, New York State Department of Environmental Conservation.

Robinson, R., Hansen, W. Orth, K. 1995. Evaluation of Environmental Investments Procedures Manual, Interim: Cost Effectiveness and Incremental Cost Analysis, U.S. Army Corps of Engineers, Water Resources Support Center, Institute for Water Resources, Alexandria, VA.

SAIC, 1990, Brookhaven National Laboratory Site Baseline Report, Science Applications International Corporation, November 1990.

Suter, G.W., 1993. Ecological Risk Assessment, Lewis Publishers, Boca Raton, $\mathrm{FL}$.

Travis, C.C., P. A. Schofield and B.P. Blaylock, 1993, "Evaluation of Remediation Worker Risk at Radioactively Contaminated Waste Sites", J. of Hazardous Materials 35:387-401. 
USDOE, 1991, DOE Guidance on the Procedures in Applying the ALARA Process For Compliance with DOE 5400.5, Interim Guidance, Office of Environmental Guidance, Assistant Secretary, Environment, Safety and Health, United States Department of Energy, March 8, 1991.

USDOE, 1992, Record of Decision for the Lawrence Livermore National Laboratory Livermore Site, Lawrence Livermore National Laboratory, University of California, UCRL-AR-109105.

USDOE, 1993, Record of Decision for Remedial Action at the Chemical Plant Area of the Weldon Spring Site, United States Department of Energy, Oak Ridge Field Office, Weldon Spring Site Remedial Action Project, DOE/OR/21548-376.

USDOE, 1994a, Remedial Investigation, Operable Unit 5, Fernald Environmental Management Project, U.S. Department of Energy, Fernald, Ohio.

USDOE, 1994b, Final Record of Decision for Remedial Actions at Operable Unit 4, Fernald Environmental Management Project, U.S. Department of Energy Fernald Field Office, Fernald, Ohio.

USDOE, 1995a, DRAFT Declaration of the Record of Decision USDOE Hanford 100 Area, Operable Units 100-BC-1, 100-DR-1, 100-HR-1, August 31, 1995. United States Department of Energy.

USDOE, 1995b. Long-Term Land Use Future Scenarios for the Idaho National Engineering Laboratory, United States Department of Energy, Idaho Operations Office, Idaho Falls, ID, DOE/ID-10440.

USDOE, 1995c, Rocky Flats Site-specific Exposure Factors for Quantitative Human Health Risk Assessment.

USDOE, 1995d. Final Record of Decision for Remedial Actions at Operable Unit 1, Fernald Environmental Management Project, US Department of Energy Fernald Field Office, Fernald, Ohio.

USDOE, 1995e. Final Record of Decision for Remedial Actions at Operable Unit 2, Fernald Environmental Management Project, US Department of Energy Fernald Field Office, Fernald, Ohio.

USDOE, 1995f. Final Record of Decision for Remedial Actions at Operable Unit 5, Fernald Environmental Management Project, US Department of Energy Fernald Field Office, Fernald, Ohio.

Yu. et al., 1993, Manual for Implementing Residual Radioactive Material Guidelines Using RESRAD Version 5.0, Argonne National Laboratory, Environmental Assessment Division, ANL/EAD/LD-2. 


\section{APPENDIX I: RESRAD PARAMETERS}

\section{PHYSICAL AND EXPOSURE PARAMETERS}

Some of the parameters used in the RESRAD analysis are generic, e.g., conversion factors, plant to soil concentration ratios, and shielding factors. These are RESRAD default values documented in Yu et al. (1993a, b). In some cases these "defaults" were dependent on soil type (e.g., $\mathrm{K}_{\mathrm{d}}$ ) or climate (e.g., annual precipitation). For $K_{d} s$, values for sand or sandy loam soil were chosen. In addition to being more appropriate for the BNL site than other options, values for sandy soil were lower than for other soil types. Climate-related parameters, e.g., humidity in air and evapotranspiration rates, were selected from maps in $\mathrm{Yu}$ et al. (1993b).

Some parameters, specific to the BNL site and applicable across the entire site, were based on site-specific information. The waste site and hydrological parameters used to develop the generic site parameters are based on assumptions for OU II/IV. These were mostly physical characteristics of the site, e.g., soil density, porosity, and hydraulic conductivity. These were based on measurements made on the BNL site. Distribution coefficients $\left(K_{d}\right)$ for strontium and uranium were also measured specifically in BNL soil. Parameters that vary by Operable Unit and Area of Concern include the area of the contaminated zone, the length parallel to aquifer flow, and depth to the water table, required to calculate the thickness of the uncontaminated unsaturated zone. These were derived from site maps, well data, and, in one case, estimated by the responsible project engineer.

Table I-1 lists the exposure pathways assumed for future land uses at BNL. Table I-2 gives RESRAD parameters used in the RME analysis. Table I-3 lists the $K_{d}$ values used, and Table 1-4 gives the RESRAD parameters used in the analysis of risk to the average receptor. Exposure parameters are described in more detail in Appendices II (RME) and III (average).

\section{GENERAL NOTES ON THE SCENARIOS}

\section{Suburban Residential Scenario}

BNL is in a suburban area that is becoming more densely populated. The BNL Future Land Use Plan (BNL, 1995a) indicates part of the site may be used for residential use. Suburban development is characterized by single family homes on $1 / 4$ to 2 acre lots.

\section{Use of the Suburban Residential Scenario instead of a Resident Farmer}

If clean-up of the site were designed toward release of the BNL site for unrestricted use at some future date, proposed EPA guidance would suggest assuming a resident-farmer land use scenario (EPA, 1995a). EPA's rationale for this requirement is that it is more protective and that "... the majority of the sites that this rule would apply to are in rural locations that realistically could be 
converted into agricultural use." (p. 38). Even for an unrestricted use, this is not a realistic scenario for the BNL site. Farming is declining on Long Island, not growing. BNL is no longer in a rural area; it is being rapidly surrounded by suburban growth with accompanying commercial and industrial development. In the absence of any institutional or local government intervention, suburban residential development would be the most likely scenario, not a family farm. Meetings with stakeholders as part of the development of the future land use plan (BNL, 1995a) produced no suggestions for agricultural use. In addition, any residential development of the BNL site would almost certainly result in provision of public water supply regardless of the quality of the groundwater underlying the site.

There are detailed plans for two shopping centers, a corporate park, and several thousand single and multiple family dwellings proposed within a $15 \mathrm{~km}$ area of the Laboratory, predominantly on the north, south and west boundaries. The area to the east of the Laboratory remains sparsely populated, and is zoned for low density residential and open space use (BNL, 1995a).

Because of the emphasis on open space preservation on eastern Long Island, especially within the Pine Barrens Core Preservation Area, development to the east of the laboratory is likely to be minimal. There is pressure for residential development in areas close to $\mathrm{BNL}$, and additional agricultural uses are not likely.

\section{Commercial/Industrial Scenario}

This scenario characterizes the exposure of potential workers at commercial or industrial enterprises that may be established on the site in the future. There are detailed plans for two shopping centers, a corporate park, and several thousand single and multiple family dwellings proposed within a $15 \mathrm{~km}$ area of the Laboratory, predominantly on the north, south and west boundaries. The area to the east of the Laboratory remains sparsely populated, and is zoned for low density residential and open space use (BNL, 1995a). Commercial or industrial development in the central area of the site would most likely be consistent with the suburban character of the area, e.g., shopping center, office park or light industry.

\section{Recreational And Open Space Scenarios}

Much of the BNL site is designated as part of the protected core area of the Long Island Pine Barrens (Central Pine Barrens Joint Planning and Policy Commission, 1995). This provides a strong basis for assuming that the future use of much of the site will be undeveloped open space. It is also possible that parts of the site may be developed for other recreational activities. For example, baseball and soccer fields already exist on site.

Two different recreational scenarios are recommended. First is an undeveloped open space scenario and the second is a developed recreational 
park with ball fields and other facilities. In both cases it would be expected that only part of the BNL site would be devoted to the single land use.

The ingestion of meat represents hunting. BNL (1995b) indicates that there will be illegal hunting (poaching), but the new open space scenario assumes that hunting may be legal after the Federal government releases the site. For the developed recreational park scenario, however, it is assumed that development of the site will not only preclude hunting, but will greatly reduce the possibility of deer grazing on the land. The ingestion of produce in the open space scenario represents the gathering of mushrooms or berries.

An example of how an open space land use might be managed is the New York State owned Rocky Point Natural Resources Management Area in which walking trails were established and, while an easily available permit is required to enter, there are no fences and no permanent staff on site. Hunting is allowed and berries or mushrooms could be gathered. No drinking water is available. The area contains 5,154 acres and receives 15,000 visitors/y (2.5 annual visitors per acre). The nearby Navy Cooperative area contains 4,026 acres and receiving 8,000 visitors/y ( 2.0 visitors/acre). The BNL site is physically close to these two properties and would have similar uses and attractions as open space. In both cases, visitor activities are hunting, hiking, nature observation, and cross-country skiing.

Access permits are required for the Rocky Point Property; but are easy to obtain. Four thousand permits are issued annually. If 5,000 people are assumed to use the property ( $25 \%$ above the number with permits), 15,000 visits $/ 5,000$ people $=3$ days per year per person. These visits are primarily people who spend, perhaps, one-half day on the property ( 3 days $\times 4 \mathrm{hrs} / \mathrm{d}=12$ hrs/y). For the RME, we assume a jogger who spends less time per visit, but is on the site regularly. Limited inquiry among current joggers on the BNL site suggests that 45 minutes to 1 hour several days per week is a reasonable estimate for a dedicated jogger, while 300 days per year may be an extreme (200 days per year may be more likely for a dedicated jogger). 
Table 1-1. Exposure pathways for future land use at BNL

\begin{tabular}{|l|l|l|l|l|}
\hline Pathway & $\begin{array}{l}\text { Industriall } \\
\text { Commercial } \\
\text { Scenario }\end{array}$ & $\begin{array}{l}\text { Suburban } \\
\text { Residential } \\
\text { Scenario }\end{array}$ & $\begin{array}{l}\text { Undeveloped } \\
\text { Open Space } \\
\text { Scenario }\end{array}$ & $\begin{array}{l}\text { Developed } \\
\text { Recreational } \\
\text { Scenario }\end{array}$ \\
\hline $\begin{array}{l}\text { External gamma } \\
\text { exposure }\end{array}$ & Yes & Yes & Yes & Yes \\
\hline Inhalation of dust & Yes & Yes & Yes & Yes \\
\hline Ingestion of plant foods & No & Yes & Yes & No \\
\hline Ingestion of meat & No & No & Yes & No \\
\hline Ingestion of milk & No & No & No & No \\
\hline Ingestion of fish & No & No & No & No \\
\hline Ingestion of water & No & No & No & No \\
\hline Ingestion of soil & Yes & Yes & Yes & Yes \\
\hline Ingestion of water & Yes & Yes & No & Yes \\
\hline $\begin{array}{l}\text { Inhalation of } \\
\text { Radon/Thoron }\end{array}$ & Yes & Yes & Yes & Yes \\
\hline
\end{tabular}


Table 1-2. RESRAD parameters for RME analysis.

\begin{tabular}{|c|c|c|c|c|c|}
\hline RESRAD Parameters & \begin{tabular}{|l|} 
Commercial/ \\
Industrial \\
Scenario
\end{tabular} & $\begin{array}{l}\text { Suburban } \\
\text { Residential } \\
\text { Scenario }\end{array}$ & \begin{tabular}{|l} 
Open \\
Space \\
Scenario
\end{tabular} & $\begin{array}{l}\text { Recreational } \\
\text { Scenario }\end{array}$ & Source \\
\hline $\begin{array}{l}\text { Area of contaminated } \\
\text { zone }\left(m^{2}\right) \\
\text { Site Specific Value }\end{array}$ & 20,000 & 20,000 & 20,000 & 20,000 & $\pi 1996$ \\
\hline $\begin{array}{l}\text { Thickness of } \\
\text { contaminated zone } \\
\text { (m) } \\
\text { Site Specific Value }\end{array}$ & 2 & 2 & 2 & 2 & Neally 1994 \\
\hline $\begin{array}{l}\text { Length parallel to } \\
\text { aquifer flow }(\mathrm{m}) \\
\text { Site Specific Value }\end{array}$ & 250 & 250 & 250 & 250 & IT 1996 \\
\hline $\begin{array}{l}\text { Basic radiation dose } \\
\text { limit (mrem/y) }\end{array}$ & 15 & $15 / 75$ & 15 & 15 & \\
\hline $\begin{array}{l}\text { Time since placement } \\
\text { of radioactive } \\
\text { material }(y)\end{array}$ & 0 & 0 & 0 & 0 & ANL 1993b p.130 \\
\hline $\begin{array}{l}\text { Cover depth }(m) \\
\text { Site Specific Value }\end{array}$ & $\overline{N A}$ & NA & NA & $\mathrm{NA}$ & \\
\hline $\begin{array}{l}\text { Density of cover } \\
\text { material }\left(\mathrm{g} / \mathrm{cm}^{3}\right) \\
\text { Site Specific Value }\end{array}$ & $\overline{\mathrm{NA}}$ & $\mathrm{NA}$ & $\mathrm{NA}$ & NA & \\
\hline $\begin{array}{l}\text { Cover depth erosion } \\
\text { rate }(\mathrm{m} / \mathrm{y}) \\
\text { Site Specific Value }\end{array}$ & NA & $\overline{\mathrm{NA}}$ & NA & $\mathrm{NA}$ & ANL 1993b p.78 \\
\hline $\begin{array}{l}\text { Density of } \\
\text { contaminated zone } \\
\left(\mathrm{g} / \mathrm{cm}^{3}\right) \\
\text { Site Specific Value }\end{array}$ & 1.66 & 1.66 & 1.66 & 1.66 & CDM 1991 \\
\hline $\begin{array}{l}\text { Contaminated zone } \\
\text { erosion rate }(\mathrm{m} / \mathrm{y}) \\
\text { Site Specific Value }\end{array}$ & 0.001 & 0.001 & 0.001 & 0.001 & ANL $1993 b$ p.78 \\
\hline $\begin{array}{l}\text { Contaminated zone } \\
\text { total porosity } \\
\text { Site Specific Value }\end{array}$ & 0.33 & 0.33 & 0.33 & 0.33 & Warren et al. 1968 \\
\hline
\end{tabular}


Table 1-2 (cont.) RESRAD parameters for RME analysis.

\begin{tabular}{|l|c|c|c|c|c|}
\hline $\begin{array}{l}\text { RESRAD } \\
\text { Parameters }\end{array}$ & $\begin{array}{l}\text { Commercial/ } \\
\text { Industrial } \\
\text { Scenario }\end{array}$ & $\begin{array}{l}\text { Suburban } \\
\text { Residential } \\
\text { Scenario }\end{array}$ & $\begin{array}{l}\text { Open } \\
\text { Space } \\
\text { Scenario }\end{array}$ & $\begin{array}{l}\text { Recreational } \\
\text { Scenario }\end{array}$ & Source \\
\hline $\begin{array}{l}\text { Contaminated zone } \\
\text { effective porosity } \\
\text { Site Specific Value }\end{array}$ & 0.24 & 0.24 & 0.24 & 0.24 & Warren et al. 1968 \\
\hline $\begin{array}{l}\text { Contaminated zone } \\
\text { hydraulic conductivity } \\
\text { (m/y) } \\
\text { Site Specific Value }\end{array}$ & 5000 & 5000 & 5000 & 5000 & $\begin{array}{l}\text { Warren et al. 1968 } \\
\text { USGS 1992 } \\
\text { CDM 1995a }\end{array}$ \\
\hline $\begin{array}{l}\text { Contaminated zone b } \\
\text { parameter }\end{array}$ & 4.9 & 4.9 & 4.9 & 4.9 & $\begin{array}{c}\text { RESRAD calc. } \\
\text { ANL 1993b p.75 }\end{array}$ \\
\hline $\begin{array}{l}\text { Evapotranspiration } \\
\text { coefficients }\end{array}$ & 0.46 & 0.46 & 0.46 & 0.46 & Penny 1994 \\
\hline $\begin{array}{l}\text { Precipitation (m/y) } \\
\text { Irrigation (m/y) }\end{array}$ & 1.23 & 1.23 & 1.23 & 1.23 & $\begin{array}{c}\text { Nagle 1975 } \\
\text { Nagle 1978 }\end{array}$ \\
\hline Irrigation mode & 0 & 0.26 & 0 & 0 & ANL 1993a,b \\
\hline Runoff coefficient & 0.2 & 0.2 & 0.2 & 0.2 & Penny 1994 \\
\hline $\begin{array}{l}\text { Watershed area from } \\
\text { nearby stream or } \\
\text { pond }\end{array}$ & $10^{6}$ & $10^{6}$ & $10^{6}$ & 10 & ANL 1993b p.83 \\
\hline $\begin{array}{l}\text { Accuracy for } \\
\text { water/soil } \\
\text { computations }\end{array}$ & 0.001 & 0.001 & 0.001 & 0.001 & ANL 1993a \\
\hline $\begin{array}{l}\text { Density of saturated } \\
\text { zone (g/cm } 3 \text { ) } \\
\text { Site Specific Value }\end{array}$ & 1.66 & 1.66 & 1.66 & 1.66 & CDM 1991 \\
\hline $\begin{array}{l}\text { Saturated zone total } \\
\text { porosity }\end{array}$ & 0.33 & 0.33 & 0.33 & 0.33 & Warren et al. 1968 \\
\hline $\begin{array}{l}\text { Saturated zone } \\
\text { effective porosity }\end{array}$ & 0.24 & 0.24 & 0.24 & 0.24 & Warren et al. 1968 \\
\hline $\begin{array}{l}\text { Saturated zone } \\
\text { hydraulic conductivity } \\
\text { (m/y) } \\
\text { Site Specific Value }\end{array}$ & 20,000 & 20,000 & 20,000 & 20,000 & CDM 1995a \\
\hline
\end{tabular}


Table I-2 (cont.) RESRAD parameters for RME analysis.

\begin{tabular}{|c|c|c|c|c|c|}
\hline $\begin{array}{l}\text { RESRAD } \\
\text { Parameters }\end{array}$ & \begin{tabular}{|l|} 
Commercial \\
/ Industrial \\
Scenario
\end{tabular} & $\begin{array}{l}\text { Suburban } \\
\text { Residential } \\
\text { Scenario }\end{array}$ & $\begin{array}{l}\text { Open } \\
\text { Space } \\
\text { Scenario }\end{array}$ & $\begin{array}{l}\text { Recreational } \\
\text { Scenario }\end{array}$ & Source \\
\hline $\begin{array}{l}\text { Saturated zone } \\
\text { hydraulic gradient } \\
\text { Site Specific Value }\end{array}$ & 0.001 & 0.001 & 0.001 & 0.001 & CDM 1995a \\
\hline $\begin{array}{l}\text { Saturated zone b } \\
\text { parameter }\end{array}$ & 4.9 & 4.9 & 4.9 & 4.9 & $\begin{array}{l}\text { RESRAD calc. } \\
\text { ANL 1993b p. } 75\end{array}$ \\
\hline $\begin{array}{l}\text { Water table drop rate } \\
(\mathrm{m} / \mathrm{y}) \\
\text { Site Specific Value }\end{array}$ & 0.001 & 0.001 & 0.001 & 0.001 & ANL 1993b p. 85 \\
\hline $\begin{array}{l}\text { Well pump intake } \\
\text { depth ( } m \text { below water } \\
\text { table) }\end{array}$ & 18 & 18 & 18 & 18 & Assumption \\
\hline $\begin{array}{l}\text { Model: Nondispersion } \\
\text { (ND) or } \\
\text { Mass-Balance (MB) }\end{array}$ & ND & ND & ND & ND & $\begin{array}{c}\text { ANL 1993a } \\
\text { App E }\end{array}$ \\
\hline $\begin{array}{l}\text { Well pumping rate } \\
\left(\mathrm{m}^{3} / \mathrm{y}\right)\end{array}$ & 250 & 250 & 250 & 250 & $\begin{array}{c}\text { Assumption } \\
\text { EPA } 1994\end{array}$ \\
\hline $\begin{array}{l}\text { Number of } \\
\text { unsaturated zone } \\
\text { strata } \\
\text { Site Specific Value }\end{array}$ & 1 & 1 & 1 & 1 & $\begin{array}{l}\text { SAIC } 1990 \\
\text { IT } 1996\end{array}$ \\
\hline $\begin{array}{l}\text { Unsat. zone 1, } \\
\text { thickness (m) } \\
\text { Site Specific Value }\end{array}$ & 8.6 & 8.6 & 8.6 & 8.6 & SAIC 1990 \\
\hline $\begin{array}{l}\text { Unsat. zone } 1 \text {, soil } \\
\text { density }\left(\mathrm{g} / \mathrm{cm}^{3}\right) \\
\text { Site Specific Value }\end{array}$ & 1.66 & 1.66 & 1.66 & 1.66 & CDM 1991 \\
\hline $\begin{array}{l}\text { Unsat. zone 1, total } \\
\text { porosity } \\
\text { Site Specific Value }\end{array}$ & 0.33 & 0.33 & 0.33 & 0.33 & Warren et al. 1968 \\
\hline $\begin{array}{l}\text { Unsat. zone 1, } \\
\text { effective porosity } \\
\text { Site Specific Value }\end{array}$ & 0.24 & 0.24 & 0.24 & 0.24 & Warren et al. 1968 \\
\hline
\end{tabular}


Table I-2 (cont.) RESRAD parameters for RME analysis.

\begin{tabular}{|c|c|c|c|c|c|}
\hline $\begin{array}{l}\text { RESRAD } \\
\text { Parameters }\end{array}$ & $\begin{array}{l}\text { Commercial } \\
\text { / Industrial } \\
\text { Scenario }\end{array}$ & $\begin{array}{l}\text { Suburban } \\
\text { Residential } \\
\text { Scenario }\end{array}$ & $\begin{array}{l}\text { Open } \\
\text { Space } \\
\text { Scenario }\end{array}$ & $\begin{array}{l}\text { Recreational } \\
\text { Scenario }\end{array}$ & Source \\
\hline $\begin{array}{l}\text { Unsat. Zone 1, } \\
\text { soil-specific b } \\
\text { parameter }\end{array}$ & 4.9 & 4.9 & 4.9 & 4.9 & $\begin{array}{l}\text { RESRAD calc. } \\
\text { ANL 1993b p.75 }\end{array}$ \\
\hline $\begin{array}{l}\text { Unsaturated zone 1, } \\
\text { hydraulic conductivity } \\
\text { (m/y) } \\
\text { Site Specific Value }\end{array}$ & 5,000 & 5,000 & 5,000 & 5,000 & $\begin{array}{l}\text { Warren } 1968 \\
\text { USGS } 1992 \\
\text { CDM 1995a }\end{array}$ \\
\hline $\begin{array}{l}\text { Exposure Frequency } \\
\text { (d/y) } \\
\text { (not used as input } \\
\text { value) }\end{array}$ & 250 & 350 & 300 & 40 & APPENDIX II \\
\hline $\begin{array}{l}\text { Daily inhalation rate } \\
\left(m^{3} / d\right) \\
\text { (not used as input } \\
\text { value) }\end{array}$ & 20 & 20 & 118 & 57.8 & APPENDIX II \\
\hline $\begin{array}{l}\text { Annual inhalation rate } \\
\left(\mathrm{m}^{3} / \mathrm{y}\right)\end{array}$ & 7,300 & 7,300 & 20,000 & 20,000 & APPENDIX II \\
\hline $\begin{array}{l}\text { Daily drinking rate } \\
\text { ( } \sim d) \text {, (not used as } \\
\text { input value) }\end{array}$ & 1 & 2 & 0 & 1 & APPENDIX II \\
\hline $\begin{array}{l}\text { Annual drinking rate } \\
(L / y)\end{array}$ & 350 & 700 & 0 & 40 & APPENDIX II \\
\hline $\begin{array}{l}\text { Mass loading for } \\
\text { inhalation }\left(\mathrm{g} / \mathrm{m}^{3}\right)\end{array}$ & 0.0001 & 0.0001 & 0.0001 & 0.0002 & $\begin{array}{c}\text { APPENDIX II } \\
\text { ANL 1993b p.110 }\end{array}$ \\
\hline $\begin{array}{l}\text { Dilution length for } \\
\text { airborne dust, } \\
\text { inhalation }(m)\end{array}$ & 3 & 3 & 3 & 3 & ANL 1993a,b \\
\hline Exposure duration $(y)$ & 25 & 30 & 30 & 30 & $\begin{array}{l}\text { EPA } 1991 \\
\text { EPA } 1994\end{array}$ \\
\hline $\begin{array}{l}\text { Shielding factor, } \\
\text { inhalation }\end{array}$ & 0.4 & 0.4 & 1.0 & 1.0 & $\begin{array}{c}\text { ANL 1993b p. } 112 \\
\text { APPENDIX } \|\end{array}$ \\
\hline
\end{tabular}


Table 2 (cont.) RESRAD parameters for RME analysis.

\begin{tabular}{|c|c|c|c|c|c|}
\hline $\begin{array}{l}\text { RESRAD } \\
\text { Parameters }\end{array}$ & $\begin{array}{l}\text { Commercial/ } \\
\text { Industrial } \\
\text { Scenario }\end{array}$ & $\begin{array}{l}\text { Suburban } \\
\text { Residential } \\
\text { Scenario }\end{array}$ & $\begin{array}{l}\text { Open } \\
\text { Space } \\
\text { Scenario }\end{array}$ & \begin{tabular}{|l|} 
Recreational \\
Scenario
\end{tabular} & Source \\
\hline $\begin{array}{l}\text { Shielding factor, } \\
\text { external gamma }\end{array}$ & 0.8 & 0.8 & 1.0 & 1.0 & $\begin{array}{c}\text { ANL 1993b p. } 129 \\
\text { APPENDIX I }\end{array}$ \\
\hline $\begin{array}{l}\text { Fraction of time } \\
\text { spent indoors }\end{array}$ & 0.06 & 0.50 & 0 & 0 & $\begin{array}{c}\text { EPA } 1994 \\
\text { EPA } 1991 \\
\text { APPENDIX II }\end{array}$ \\
\hline $\begin{array}{l}\text { Fraction of time } \\
\text { spent outdoors }\end{array}$ & 0.17 & 0.25 & 0.073 & 0.032 & $\begin{array}{c}\text { EPA } 1994 \\
\text { EPA } 1991 \\
\text { APPENDIX II }\end{array}$ \\
\hline $\begin{array}{l}\text { Shape factor, } \\
\text { external gamma }\end{array}$ & 1.0 & 1.0 & 1.0 & 1.0 & ANL 1993b p. 131 \\
\hline $\begin{array}{l}\text { Fruits, vegetables } \\
\text { and grain } \\
\text { consumption }(\mathrm{kg} / \mathrm{y})\end{array}$ & 0 & 160 & 160 & 0 & APPENDIX II \\
\hline $\begin{array}{l}\text { Leafy vegetable } \\
\text { consumption (kg/y) }\end{array}$ & 0 & 14 & 0 & 0 & APPENDIX II \\
\hline $\begin{array}{l}\text { Meat ingestion rate } \\
(\mathrm{kg} / \mathrm{y})\end{array}$ & 0 & 0 & 63 & 0 & APPENDIX II \\
\hline $\begin{array}{l}\text { Soil ingestion rate } \\
(\mathrm{g} / \mathrm{y})\end{array}$ & 36.5 & 43.8 & 36.5 & 65.7 & APPENDIX II \\
\hline $\begin{array}{l}\text { Household water } \\
\text { fraction } \\
\text { contaminated }\end{array}$ & 1 & 1 & 0 & 1 & APPENDIX II \\
\hline $\begin{array}{l}\text { Livestock water } \\
\text { fraction } \\
\text { contaminated }\end{array}$ & 0 & 0 & 0 & 0 & \\
\hline $\begin{array}{l}\text { Irrigation water } \\
\text { fraction } \\
\text { contaminated }\end{array}$ & 0 & 1 & 0 & 0 & APPENDIX II \\
\hline $\begin{array}{l}\text { Contaminated } \\
\text { fraction of plants }\end{array}$ & 0 & 0.2 & 0.006 & 0 & APPENDIX II \\
\hline $\begin{array}{l}\text { Contaminated } \\
\text { fraction of meat }\end{array}$ & 0 & 0 & 0.14 & 0 & APPENDIX II \\
\hline
\end{tabular}


Table I-2 (cont.) RESRAD parameters for RME analysis.

\begin{tabular}{|c|c|c|c|c|c|}
\hline $\begin{array}{l}\text { RESRAD } \\
\text { Parameters }\end{array}$ & $\begin{array}{l}\text { Commercial/ } \\
\text { Industrial } \\
\text { Scenario }\end{array}$ & $\begin{array}{l}\text { Suburban } \\
\text { Residential } \\
\text { Scenario }\end{array}$ & $\begin{array}{l}\text { Open Space } \\
\text { Scenario }\end{array}$ & $\begin{array}{l}\text { Recreational } \\
\text { Scenario }\end{array}$ & Source \\
\hline $\begin{array}{l}\text { Livestock fodder } \\
\text { intake for meat } \\
\text { (kg/d) }\end{array}$ & 0 & 0 & 68 & 0 & $\begin{array}{l}\text { ANL 1993a } \\
\text { p.181 }\end{array}$ \\
\hline $\begin{array}{l}\text { Livestock water } \\
\text { intake for meat ( } U d)\end{array}$ & 0 & 0 & 50 & 0 & ANL 1993a,b \\
\hline $\begin{array}{l}\text { Livestock intake for } \\
\text { soil (kg/d) }\end{array}$ & 0 & 0 & 0.5 & 0 & APPENDIX II \\
\hline $\begin{array}{l}\text { Mass loading for } \\
\text { foliar deposition } \\
\left(\mathrm{g} / \mathrm{m}^{3}\right)\end{array}$ & $\overline{\mathrm{NA}}$ & 0.0001 & 0.0001 & 0.0001 & $\begin{array}{l}\text { APPENDIX II } \\
\text { ANL 1993b } \\
\text { p.110 }\end{array}$ \\
\hline $\begin{array}{l}\text { Depth of soil mixing } \\
\text { layer }(m)\end{array}$ & 0.15 & 0.15 & 0.15 & 0.15 & ANL 1993a,b \\
\hline Depth of roots $(m)$ & $\mathrm{NA}$ & 0.9 & 0.9 & NA & $\begin{array}{l}\text { ANL 1993b p. } \\
113\end{array}$ \\
\hline $\begin{array}{l}\text { Household fractional } \\
\text { usage from } \\
\text { groundwater }\end{array}$ & 1 & 1 & 0 & 1 & APPENDIX II \\
\hline $\begin{array}{l}\text { Irrigation fractional } \\
\text { usage from } \\
\text { groundwater }\end{array}$ & 0 & 1 & 0 & 0 & APPENDIX II \\
\hline $\begin{array}{l}\text { Livestock fractional } \\
\text { usage from } \\
\text { groundwater }\end{array}$ & 0 & 0 & 0 & 0 & \\
\hline \multicolumn{6}{|l|}{$\begin{array}{l}\text { Storage times for } \\
\text { contaminated } \\
\text { foodstuffs }\end{array}$} \\
\hline $\begin{array}{l}\text { Fruits, non-leafy } \\
\text { veg. \& grains (d) }\end{array}$ & NA & 14 & 14 & NA & APPENDIX II \\
\hline Leafy vegetables (d) & NA & 1 & 1 & $\overline{N A}$ & APPENDIX II \\
\hline Meat (d) & $\overline{N A}$ & $\overline{\mathrm{NA}}$ & 20 & $\mathrm{NA}$ & APPENDIX II \\
\hline Water well (d) & $\overline{N A}$ & 1 & 1 & $\overline{N A}$ & APPENDIX II \\
\hline Water surface (d) & $\overline{\mathrm{NA}}$ & 1 & 1 & $\overline{\mathrm{NA}}$ & APPENDIX II \\
\hline Livestock fodder (d) & $\overline{\mathrm{NA}}$ & $\overline{N A}$ & 0 & $\overline{\mathrm{NA}}$ & APPENDIXIII \\
\hline
\end{tabular}


Table I-2 (cont.) RESRAD parameters for RME analysis.

\begin{tabular}{|c|c|c|c|c|c|}
\hline $\begin{array}{l}\text { RESRAD } \\
\text { Parameters }\end{array}$ & $\begin{array}{l}\text { Commercial/ } \\
\text { Industrial } \\
\text { Scenario }\end{array}$ & \begin{tabular}{l|} 
Suburban \\
Residential \\
Scenario
\end{tabular} & $\begin{array}{l}\text { Open Space } \\
\text { Scenario }\end{array}$ & $\begin{array}{l}\text { Recreational } \\
\text { Scenario }\end{array}$ & Source \\
\hline \multicolumn{6}{|l|}{$\begin{array}{l}\text { Thickness of } \\
\text { material }(\mathrm{m})\end{array}$} \\
\hline \multicolumn{6}{|l|}{$\begin{array}{l}\text { Site Specific } \\
\text { Values }\end{array}$} \\
\hline in foundation & 0.15 & 0.15 & $\mathrm{NA}$ & NA & $\begin{array}{l}\text { ANL 1993b } \\
\text { p.52 }\end{array}$ \\
\hline $\begin{array}{l}\text { in } \\
\text { contaminated zone } \\
\text { soil }\end{array}$ & 0 & 0 & 0 & 0 & $\begin{array}{l}\text { ANL 1993b } \\
\text { p.52 }\end{array}$ \\
\hline \multicolumn{6}{|l|}{$\begin{array}{l}\text { Density of material } \\
(\mathrm{g} / \mathrm{cm} 3)\end{array}$} \\
\hline \multicolumn{6}{|l|}{$\begin{array}{l}\text { Site Specific } \\
\text { Values }\end{array}$} \\
\hline $\begin{array}{l}\text { in the } \\
\text { foundation }\end{array}$ & 2.4 & 2.4 & NA & NA & ANL 1993a,b \\
\hline $\begin{array}{c}\text { in the } \\
\text { contaminated soil }\end{array}$ & NA & $\mathrm{NA}$ & $\mathrm{NA}$ & $\mathrm{NA}$ & ANL 1993a,b \\
\hline \multicolumn{6}{|l|}{$\begin{array}{l}\text { Total porosity of } \\
\text { material }\end{array}$} \\
\hline \multicolumn{6}{|l|}{$\begin{array}{l}\text { Site Specific } \\
\text { Values }\end{array}$} \\
\hline $\begin{array}{l}\text { in the } \\
\text { foundation }\end{array}$ & 0.1 & 0.1 & $\mathrm{NA}$ & $\mathrm{NA}$ & $\begin{array}{l}\text { ANL } 1993 \mathrm{~b} \\
\text { p. } 44\end{array}$ \\
\hline $\begin{array}{c}\text { in the } \\
\text { contaminated soil }\end{array}$ & $\overline{N A}$ & $\mathrm{NA}$ & $\overline{\mathrm{NA}}$ & $\mathrm{NA}$ & $\begin{array}{l}\text { ANL 1993b } \\
\text { p.44 }\end{array}$ \\
\hline \multicolumn{6}{|l|}{$\begin{array}{l}\text { Volumetric water } \\
\text { content }\end{array}$} \\
\hline \multicolumn{6}{|l|}{$\begin{array}{l}\text { Site Specific } \\
\text { Values }\end{array}$} \\
\hline $\begin{array}{c}\text { in the } \\
\text { foundation }\end{array}$ & 0.03 & 0.03 & $\mathrm{NA}$ & $\mathrm{NA}$ & $\begin{array}{c}\text { RESRAD calc. } \\
\text { ANL } 1993 \mathrm{~b} \\
\text { p.47 }\end{array}$ \\
\hline $\begin{array}{c}\text { in the } \\
\text { contaminated soil }\end{array}$ & $\overline{\mathrm{NA}}$ & NA & $\overline{\mathrm{NA}}$ & $\overline{N A}$ & $\begin{array}{c}\text { RESRAD calc. } \\
\text { ANL } 1993 \mathrm{~b} \\
\text { p. } 47\end{array}$ \\
\hline
\end{tabular}


Table I-2 (cont.) RESRAD parameters for RME analysis.

\begin{tabular}{|c|c|c|c|c|c|}
\hline $\begin{array}{l}\text { RESRAD } \\
\text { Parameters }\end{array}$ & $\begin{array}{l}\text { Commercial/ } \\
\text { Industrial } \\
\text { Scenario }\end{array}$ & $\begin{array}{l}\text { Suburban } \\
\text { Residential } \\
\text { Scenario }\end{array}$ & $\begin{array}{l}\text { Open Space } \\
\text { Scenario }\end{array}$ & $\begin{array}{l}\text { Recreational } \\
\text { Scenario }\end{array}$ & Source \\
\hline \multirow{2}{*}{\multicolumn{6}{|c|}{$\begin{array}{l}\text { Diffusion coefficient } \\
\text { for radon gas } \\
(\mathrm{m} / \mathrm{sec}) \\
\text { Site Specific } \\
\text { Values }\end{array}$}} \\
\hline & & & & & \\
\hline $\begin{array}{r}\text { in the } \\
\text { foundation }\end{array}$ & $3 E-7$ & $3 \mathrm{E}-7$ & NA & NA & $\begin{array}{l}\text { ANL } 1993 \mathrm{~b} \\
\text { p.52 }\end{array}$ \\
\hline $\begin{array}{c}\text { in the } \\
\text { contaminated soil }\end{array}$ & NA & NA & NA & NA & $\begin{array}{l}\text { ANL 1993b } \\
\text { p. } 52\end{array}$ \\
\hline $\begin{array}{l}\text { Contamination zone } \\
\text { radon diffusion } \\
\text { coefficient }\end{array}$ & $2 \mathrm{E}-6$ & $2 E-6$ & $2 \mathrm{E}-6$ & $2 E-6$ & $\begin{array}{l}\text { ANL 1993b } \\
\text { p.52 }\end{array}$ \\
\hline $\begin{array}{l}\text { Radon vertical } \\
\text { dimension of mixing }\end{array}$ & 2 & 2 & 2 & 2 & $\begin{array}{l}\text { ANL } 1993 \mathrm{~b} \\
\text { p. } 87\end{array}$ \\
\hline $\begin{array}{l}\text { Average annual wind } \\
\text { speed }(\mathrm{m} / \mathrm{sec})\end{array}$ & 6.23 & 6.23 & 6.23 & 6.23 & Nagle 1975 \\
\hline $\begin{array}{l}\text { Average building air } \\
\text { exchange rate }(1 / \mathrm{hr})\end{array}$ & 0.5 & 0.5 & NA & NA & $\begin{array}{l}\text { ANL 1993b } \\
\text { p. } 89\end{array}$ \\
\hline $\begin{array}{l}\text { Height of the } \\
\text { building (room) }(\mathrm{m})\end{array}$ & 2.5 & 2.5 & NA & NA & $\begin{array}{l}\text { ANL } 1993 \mathrm{~b} \\
\text { p.91 }\end{array}$ \\
\hline $\begin{array}{l}\text { Building interior area } \\
\text { factor }\end{array}$ & 0 & 0 & NA & NA & $\begin{array}{l}\text { ANL 1993b } \\
\text { p.92 }\end{array}$ \\
\hline $\begin{array}{l}\text { Building depth below } \\
\text { ground surface }(m)\end{array}$ & 1 & 1 & NA & NA & $\begin{array}{l}\text { ANL 1993b } \\
\text { p.95 }\end{array}$ \\
\hline $\begin{array}{l}\text { Emanating power of } \\
\text { Rn-222 gas }\end{array}$ & 0.25 & 0.25 & 0.25 & 0.25 & $\begin{array}{l}\text { ANL 1993b } \\
\text { p.58 }\end{array}$ \\
\hline $\begin{array}{l}\text { Emanating power of } \\
\text { Rn-220 gas }\end{array}$ & 0.15 & 0.15 & 0.15 & 0.15 & $\begin{array}{l}\text { ANL 1993b } \\
\text { p.58 }\end{array}$ \\
\hline
\end{tabular}


Table-l-3. Distribution coefficients used in deriving generic site guidelines (use site specific values if available).

\begin{tabular}{|c|c|c|}
\hline Radionuclide & $\begin{array}{c}\text { Distribution } \\
\text { Coefficient }\end{array}$ & Source \\
\hline Americium-241 & $1.9 \mathrm{E}+3$ & ANL 1993b p.107 \\
\hline Cesium-137 & $2.8 \mathrm{E}+1$ & ANL 1993b p.107 \\
\hline Cobalt-60 & $6.0 \mathrm{E}+1$ & ANL 1993b p.107 \\
\hline Europium-152 & $5.8 \mathrm{E}+2$ & ANL 1993b p.107 \\
\hline Europium-154 & $5.8 \mathrm{E}+2$ & ANL 1993b p.107 \\
\hline Europium-155 & $5.8 \mathrm{E}+2$ & ANL 1993b p.107 \\
\hline Plutonium-238 & $5.5 \mathrm{E}+2$ & ANL 1993b p.107 \\
\hline Plutonium-239 & $5.5 \mathrm{E}+2$ & ANL 1993b p.107 \\
\hline Plutonium-240 & $5.5 \mathrm{E}+2$ & ANL 1993b p.107 \\
\hline Radium-226 & 2 & ANL 1993, p. 107. \\
\hline Strontium-90 & $3.0 \mathrm{E}+0$ & CDM 1995b \\
\hline Uranium-234 & $1.7 \mathrm{E}+1$ & Fuhrmann 1995 \\
\hline Uranium-235 & $1.7 \mathrm{E}+1$ & Fuhrmann 1995 \\
\hline Uranium-238 & $1.7 \mathrm{E}+1$ & Fuhrmann 1995 \\
\hline
\end{tabular}


Table 1-4. RESRAD parameters for average exposure case

\begin{tabular}{|l|c|c|c|c|c|}
\hline RESRAD Parameters & $\begin{array}{l}\text { Commerciall } \\
\text { Industrial } \\
\text { Scenario }\end{array}$ & $\begin{array}{l}\text { Suburban } \\
\text { Residential } \\
\text { Scenario }\end{array}$ & $\begin{array}{l}\text { Open } \\
\text { Space } \\
\text { Scenario }\end{array}$ & $\begin{array}{l}\text { Suburban } \\
\text { Recreational } \\
\text { Scenario }\end{array}$ & Source \\
\hline $\begin{array}{l}\text { Area of contaminated } \\
\text { zone (m) } \\
\text { Site Specific Value }\end{array}$ & 20,000 & 20,000 & 20,000 & 20,000 & IT 1996 \\
\hline $\begin{array}{l}\text { Thickness of } \\
\text { contaminated zone } \\
\text { (m) } \\
\text { Site Specific Value }\end{array}$ & 2 & 2 & 2 & 2 & Neally 1994 \\
\hline $\begin{array}{l}\text { Length parallel to } \\
\text { aquifer flow (m) } \\
\text { Site Specific Value }\end{array}$ & 250 & 250 & 250 & 250 & IT 1996 \\
\hline $\begin{array}{l}\text { Basic radiation dose } \\
\text { limit (mrem/y) }\end{array}$ & 15 & $15 / 75$ & 15 & 15 & ANL 1993b p.130 \\
\hline $\begin{array}{l}\text { Time since placement } \\
\text { of radioactive } \\
\text { material (y) }\end{array}$ & 0 & 0 & 0 & 0 & ANL 1993b p.78 \\
\hline $\begin{array}{l}\text { Cover depth (m) } \\
\text { Site Specific Value }\end{array}$ & NA & NA & NA & NA & \\
\hline $\begin{array}{l}\text { Density of cover } \\
\text { material (g/cm } \\
\text { Site Specific Value }\end{array}$ & NA & NA & NA & NA & \\
\hline $\begin{array}{l}\text { Cover depth erosion } \\
\text { rate (m/y) } \\
\text { Site Specific Value }\end{array}$ & NA & NA & NA & NA & ANL 1993b p.78 \\
\hline $\begin{array}{l}\text { Density of } \\
\text { contaminated zone } \\
\text { (g/cm }{ }^{3} \text { ) } \\
\text { Site Specific Value }\end{array}$ & 1.66 & 1.66 & 1.66 & 1.66 & CDM 1991 \\
\hline $\begin{array}{l}\text { Contaminated zone } \\
\text { erosion rate (m/y) } \\
\text { Site Specific Value }\end{array}$ & 0.001 & 0.001 & 0.001 & 0.001 & \\
\hline $\begin{array}{l}\text { Contaminated zone } \\
\text { total porosity } \\
\text { Site Specific Value }\end{array}$ & 0.33 & 0.33 & 0.33 & 0.33 & \\
\hline
\end{tabular}


Table I-4 (cont.) RESRAD parameters for average exposure case

\begin{tabular}{|c|c|c|c|c|c|}
\hline $\begin{array}{l}\text { RESRAD } \\
\text { Parameters }\end{array}$ & $\begin{array}{l}\text { Commerciall } \\
\text { Industrial } \\
\text { Scenario }\end{array}$ & $\begin{array}{l}\text { Suburban } \\
\text { Residential } \\
\text { Scenario }\end{array}$ & $\begin{array}{l}\text { Open } \\
\text { Space } \\
\text { Scenario }\end{array}$ & $\begin{array}{l}\text { Recreational } \\
\text { Scenario }\end{array}$ & Source \\
\hline $\begin{array}{l}\text { Contaminated zone } \\
\text { effective porosity } \\
\text { Site Specific Value }\end{array}$ & 0.24 & 0.24 & 0.24 & 0.24 & Warren et al. 1968 \\
\hline $\begin{array}{l}\text { Contaminated zone } \\
\text { hydraulic conductivity } \\
(\mathrm{m} / \mathrm{y}) \\
\text { Site Specific Value }\end{array}$ & 5000 & 5000 & 5000 & 5000 & $\begin{array}{l}\text { Warren et al. } 1968 \\
\text { USGS } 1992 \\
\text { CDM 1995a }\end{array}$ \\
\hline $\begin{array}{l}\text { Contaminated zone } \mathrm{b} \\
\text { parameter }\end{array}$ & 4.9 & 4.9 & 4.9 & 4.9 & $\begin{array}{l}\text { RESRAD calc. } \\
\text { ANL 1993b p.75 }\end{array}$ \\
\hline $\begin{array}{l}\text { Evapotranspiration } \\
\text { coefficients }\end{array}$ & 0.46 & 0.46 & 0.46 & 0.46 & Penny 1994 \\
\hline Precipitation $(\mathrm{m} / \mathrm{y})$ & 1.23 & 1.23 & 1.23 & 1.23 & $\begin{array}{l}\text { Nagle } 1975 \\
\text { Nagle } 1978\end{array}$ \\
\hline Irrigation (m/y) & 0 & 0.26 & 0 & 0 & ANL 1993a,b \\
\hline Irrigation mode & NA & Overhead & NA & NA & \\
\hline Runoff coefficient & 0.2 & 0.2 & 0.2 & 0.2 & Penny 1994 \\
\hline $\begin{array}{l}\text { Watershed area from } \\
\text { nearby stream or } \\
\text { pond }\end{array}$ & $10^{6}$ & $10^{6}$ & $10^{6}$ & $10^{6}$ & ANL 1993b p.83 \\
\hline $\begin{array}{l}\text { Accuracy for } \\
\text { water/soil } \\
\text { computations }\end{array}$ & 0.001 & 0.001 & 0.001 & 0.001 & ANL 1993a \\
\hline $\begin{array}{l}\text { Density of saturated } \\
\text { zone }\left(\mathrm{g} / \mathrm{cm}^{3}\right) \\
\text { Site Specific Value }\end{array}$ & 1.66 & 1.66 & 1.66 & 1.66 & CDM 1991 \\
\hline $\begin{array}{l}\text { Saturated zone total } \\
\text { porosity }\end{array}$ & 0.33 & 0.33 & 0.33 & 0.33 & Warren et al. 1968 \\
\hline $\begin{array}{l}\text { Saturated zone } \\
\text { effective porosity }\end{array}$ & 0.24 & $0: 24$ & 0.24 & 0.24 & Warren et al. 1968 \\
\hline $\begin{array}{l}\text { Saturated zone } \\
\text { hydraulic conductivity } \\
(\mathrm{m} / \mathrm{y}) \\
\text { Site Specific Value }\end{array}$ & 20,000 & 20,000 & 20,000 & 20,000 & CDM 1995a \\
\hline
\end{tabular}


Table 1-4 (cont). RESRAD parameters for average exposure case

\begin{tabular}{|c|c|c|c|c|c|}
\hline $\begin{array}{l}\text { RESRAD } \\
\text { Parameters }\end{array}$ & $\begin{array}{l}\text { Commercial } \\
\text { I Industrial } \\
\text { Scenario }\end{array}$ & $\begin{array}{l}\text { Suburban } \\
\text { Residential } \\
\text { Scenario }\end{array}$ & $\begin{array}{l}\text { Open } \\
\text { Space } \\
\text { Scenario }\end{array}$ & $\begin{array}{l}\text { Recreational } \\
\text { Scenario }\end{array}$ & Source \\
\hline $\begin{array}{l}\text { Saturated zone } \\
\text { hydraulic gradient } \\
\text { Site Specific Value }\end{array}$ & 0.001 & 0.001 & 0.001 & 0.001 & CDM 1995a \\
\hline $\begin{array}{l}\text { Saturated zone } b \\
\text { parameter }\end{array}$ & 4.9 & 4.9 & 4.9 & 4.9 & $\begin{array}{l}\text { RESRAD calc. } \\
\text { ANL 1993b p. } 75\end{array}$ \\
\hline $\begin{array}{l}\text { Water table drop rate } \\
(\mathrm{m} / \mathrm{y}) \\
\text { Site Specific Value }\end{array}$ & 0.001 & 0.001 & 0.001 & 0.001 & ANL 1993b p. 85 \\
\hline $\begin{array}{l}\text { Well pump intake } \\
\text { depth ( } \mathrm{m} \text { below water } \\
\text { table) }\end{array}$ & 18 & 18 & 18 & 18 & Assumption \\
\hline $\begin{array}{l}\text { Model: Nondispersion } \\
\text { (ND) or } \\
\text { Mass-Balance (MB) }\end{array}$ & $\overline{N D}$ & ND & ND & ND & $\begin{array}{c}\text { ANL 1993a } \\
\text { App E }\end{array}$ \\
\hline $\begin{array}{l}\text { Well pumping rate } \\
\left(\mathrm{m}^{3} / \mathrm{y}\right) \\
\text { Site Specific Value }\end{array}$ & 250 & 250 & 250 & 250 & $\begin{array}{l}\text { Assumption } \\
\text { EPA } 1994\end{array}$ \\
\hline $\begin{array}{l}\text { Number of } \\
\text { unsaturated zone } \\
\text { strata } \\
\text { Site Specific Value }\end{array}$ & 1 & 1 & 1 & 1 & SAIC 1990 \\
\hline $\begin{array}{l}\text { Unsat. zone 1, } \\
\text { thickness }(\mathrm{m}) \\
\text { Site Specific Value }\end{array}$ & 8.6 & 8.6 & 8.6 & 8.6 & SAIC 1990 \\
\hline $\begin{array}{l}\text { Unsat. zone } 1 \text {, soil } \\
\text { density }\left(\mathrm{g} / \mathrm{cm}^{3}\right) \\
\text { Site Specific Value }\end{array}$ & 1.66 & 1.66 & 1.66 & 1.66 & CDM 1991 \\
\hline $\begin{array}{l}\text { Unsat. Zone 1, total } \\
\text { porosity } \\
\text { Site Specific Value }\end{array}$ & 0.33 & 0.33 & 0.33 & 0.33 & Warren et al. 1968 \\
\hline $\begin{array}{l}\text { Unsat. zone 1, } \\
\text { effective porosity } \\
\text { Site Specific Value }\end{array}$ & 0.24 & 0.24 & 0.24 & 0.24 & Warren et al. 1968 \\
\hline
\end{tabular}


Table l-4 (cont.) RESRAD parameters for average exposure case

\begin{tabular}{|c|c|c|c|c|c|}
\hline $\begin{array}{l}\text { RESRAD } \\
\text { Parameters }\end{array}$ & $\begin{array}{l}\text { Commercial } \\
I \text { Industrial } \\
\text { Scenario }\end{array}$ & $\begin{array}{l}\text { Suburban } \\
\text { Residential } \\
\text { Scenario }\end{array}$ & $\begin{array}{l}\text { Open } \\
\text { Space } \\
\text { Scenario }\end{array}$ & $\begin{array}{l}\text { Recreational } \\
\text { Scenario }\end{array}$ & Source \\
\hline $\begin{array}{l}\text { Unsat. zone 1, } \\
\text { soil-specific b } \\
\text { parameter }\end{array}$ & 4.9 & 4.9 & 4.9 & 4.9 & $\begin{array}{l}\text { RESRAD calc. } \\
\text { ANL 1993b p.75 }\end{array}$ \\
\hline $\begin{array}{l}\text { Unsaturated zone } 1, \\
\text { hydraulic conductivity } \\
\text { (m/y) } \\
\text { Site Specific Value }\end{array}$ & 5,000 & 5,000 & 5,000 & 5,000 & $\begin{array}{l}\text { Warren } 1968 \\
\text { USGS } 1992 \\
\text { CDM 1995a }\end{array}$ \\
\hline $\begin{array}{l}\text { Exposure Frequency } \\
\text { (d/y) } \\
\text { (not used as input } \\
\text { value) }\end{array}$ & 250 & 350 & 3 & 20 & APPENDIX III \\
\hline $\begin{array}{l}\text { Daily inhalation rate } \\
\left(\mathrm{m}^{3} / \mathrm{d}\right) \\
\text { (not used as input } \\
\text { value) }\end{array}$ & 20 & 20 & 41 & 55 & APPENDIX III \\
\hline $\begin{array}{l}\text { Annual inhalation rate } \\
\left(\mathrm{m}^{3} / \mathrm{y}\right)\end{array}$ & 7,300 & 7,300 & 15,000 & 20,000 & APPENDIX III \\
\hline $\begin{array}{l}\text { Daily drinking rate } \\
\text { (L/d), (not used as } \\
\text { input value) }\end{array}$ & 0.6 & 1.2 & 0 & 0.6 & APPENDIX III \\
\hline $\begin{array}{l}\text { Annual drinking rate } \\
(L / y)\end{array}$ & 150 & 420 & NA & 12 & APPENDIX III \\
\hline $\begin{array}{l}\text { Mass loading for } \\
\text { inhalation }\left(\mathrm{g} / \mathrm{m}^{3}\right)\end{array}$ & 0.00001 & 0.00001 & 0.00001 & 0.00002 & APPENDIX III \\
\hline $\begin{array}{l}\text { Dilution length for } \\
\text { airbome dust, } \\
\text { inhalation }(\mathrm{m})\end{array}$ & 3 & 3 & 3 & 3 & ANL 1993 a,b \\
\hline Exposure duration (y) & 25 & 30 & 30 & 30 & $\begin{array}{l}\text { EPA } 1991 \\
\text { EPA } 1994\end{array}$ \\
\hline $\begin{array}{l}\text { Shielding factor, } \\
\text { inhalation }\end{array}$ & 0.4 & 0.4 & 1.0 & 1.0 & APPENDIX III \\
\hline
\end{tabular}


Table 1-4 (cont.) RESRAD parameters for average exposure case

\begin{tabular}{|c|c|c|c|c|c|}
\hline $\begin{array}{l}\text { RESRAD } \\
\text { Parameters }\end{array}$ & $\begin{array}{l}\text { Commercial/ } \\
\text { Industrial } \\
\text { Scenario }\end{array}$ & $\begin{array}{l}\text { Suburban } \\
\text { Residential } \\
\text { Scenario }\end{array}$ & $\begin{array}{l}\text { Open } \\
\text { Space } \\
\text { Scenario }\end{array}$ & \begin{tabular}{|l|} 
Recreational \\
Scenario
\end{tabular} & Source \\
\hline $\begin{array}{l}\text { Shielding factor, } \\
\text { external gamma }\end{array}$ & 0.8 & 0.8 & 1.0 & 1.0 & APPENDIX III \\
\hline $\begin{array}{l}\text { Fraction of time } \\
\text { spent indoors }\end{array}$ & 0.21 & 0.57 & 0 & 0 & APPENDIX III \\
\hline $\begin{array}{l}\text { Fraction of time } \\
\text { spent outdoors }\end{array}$ & 0.03 & 0.03 & 0.0014 & 0.009 & APPENDIX III \\
\hline $\begin{array}{l}\text { Shape factor, } \\
\text { external gamma }\end{array}$ & 1.0 & 1.0 & 1.0 & 1.0 & ANL 1993 b p. 131 \\
\hline $\begin{array}{l}\text { Fruits, vegetables } \\
\text { and grain } \\
\text { consumption }(\mathrm{kg} / \mathrm{y})\end{array}$ & 0 & 160 & 160 & 0 & APPENDIX III \\
\hline $\begin{array}{l}\text { Leafy vegetable } \\
\text { consumption }(\mathrm{kg} / \mathrm{y})\end{array}$ & 0 & $\overline{14}$ & 0 & 0 & APPENDIXIII \\
\hline $\begin{array}{l}\text { Meat ingestion rate } \\
(\mathrm{kg} / \mathrm{y})\end{array}$ & 0 & 0 & 51.1 & 0 & APPENDIX III \\
\hline $\begin{array}{l}\text { Soil ingestion rate } \\
(g / y)\end{array}$ & 2.4 & 22 & 18 & 27 & APPENDIX III \\
\hline $\begin{array}{l}\text { Household water } \\
\text { fraction } \\
\text { contaminated }\end{array}$ & 1 & 1 & 0 & 7 & \\
\hline $\begin{array}{l}\text { Livestock water } \\
\text { fraction } \\
\text { contaminated }\end{array}$ & 0 & 0 & 0 & 0 & \\
\hline $\begin{array}{l}\text { Irrigation water } \\
\text { fraction } \\
\text { contaminated }\end{array}$ & 0 & 1 & 0 & 0 & \\
\hline $\begin{array}{l}\text { Contaminated } \\
\text { fraction of plants }\end{array}$ & 0 & 0.1 & 0.0003 & 0 & APPENDIX III \\
\hline $\begin{array}{l}\text { Contaminated } \\
\text { fraction of meat }\end{array}$ & 0 & 0 & 0.02 & 0 & APPENDIX III \\
\hline
\end{tabular}


Table 1-4 (cont.) RESRAD parameters for average exposure case

\begin{tabular}{|c|c|c|c|c|c|}
\hline $\begin{array}{l}\text { RESRAD } \\
\text { Parameters }\end{array}$ & $\begin{array}{l}\text { Commercial/ } \\
\text { Industrial } \\
\text { Scenario }\end{array}$ & $\begin{array}{l}\text { Suburban } \\
\text { Residential } \\
\text { Scenario }\end{array}$ & $\begin{array}{l}\text { Open Space } \\
\text { Scenario }\end{array}$ & $\begin{array}{l}\text { Recreational } \\
\text { Scenario }\end{array}$ & Source \\
\hline $\begin{array}{l}\text { Livestock fodder } \\
\text { intake for meat } \\
\text { (kg/d) }\end{array}$ & 0 & $\overline{0}$ & 6.8 & 0 & $\begin{array}{l}\text { ANL 1993a } \\
\text { p.181 }\end{array}$ \\
\hline $\begin{array}{l}\text { Livestock water } \\
\text { intake for meat }(\mathrm{l} / \mathrm{d})\end{array}$ & 0 & 0 & 50 & 0 & ANL 1993a,b \\
\hline $\begin{array}{l}\text { Livestock intake for } \\
\text { soil }(\mathrm{kg} / \mathrm{d})\end{array}$ & 0 & 0 & 0.05 & 0 & APPENDIX III \\
\hline $\begin{array}{l}\text { Mass loading for } \\
\text { foliar deposition } \\
\left(\mathrm{g} / \mathrm{m}^{3}\right)\end{array}$ & 0.00001 & 0.00001 & 0.00001 & 0.00001 & APPENDIX III \\
\hline $\begin{array}{l}\text { Depth of soil mixing } \\
\text { layer }(\mathrm{m})\end{array}$ & 0.15 & 0.15 & 0.15 & 0.15 & ANL 1993a,b \\
\hline Depth of roots $(\mathrm{m})$ & NA & 0.9 & 0.9 & NA & $\begin{array}{c}\text { ANL 1993b p. } \\
113\end{array}$ \\
\hline $\begin{array}{l}\text { Household fractional } \\
\text { usage from } \\
\text { groundwater }\end{array}$ & 1 & 1 & 0 & 1 & APPENDIX III \\
\hline $\begin{array}{l}\text { Irrigation fractional } \\
\text { usage from } \\
\text { groundwater }\end{array}$ & 0 & 1 & 0 & 0 & APPENDIX III \\
\hline $\begin{array}{l}\text { Livestock fractional } \\
\text { usage from } \\
\text { groundwater }\end{array}$ & 0 & 0 & 0 & 0 & APPENDIX III \\
\hline \multicolumn{6}{|l|}{$\begin{array}{l}\text { Storage times for } \\
\text { contaminated } \\
\text { foodstuffs }\end{array}$} \\
\hline $\begin{array}{l}\text { Fruits, non-leafy } \\
\text { veg. \& grains (d) }\end{array}$ & NA & 14 & 14 & NA & APPENDIX III \\
\hline Leafy vegetables (d) & NA & 1 & 1 & NA & APPENDIX III \\
\hline Meat (d) & NA & NA & 20 & NA & APPENDIX III \\
\hline Water well (d) & NA & 1 & 1 & NA & APPENDIX III \\
\hline Water surface $(d)$ & NA & 1 & 1 & NA & APPENDIX III \\
\hline Livestock fodder (d) & NA & NA & 0 & NA & APPENDIX III \\
\hline
\end{tabular}


Table 1-4 (cont). RESRAD parameters for average exposure case

\begin{tabular}{|c|c|c|c|c|c|}
\hline $\begin{array}{l}\text { RESRAD } \\
\text { Parameters }\end{array}$ & $\begin{array}{l}\text { Commercial/ } \\
\text { Industrial } \\
\text { Scenario }\end{array}$ & $\begin{array}{l}\text { Suburban } \\
\text { Residential } \\
\text { Scenario }\end{array}$ & $\begin{array}{l}\text { Open Space } \\
\text { Scenario }\end{array}$ & $\begin{array}{l}\text { Recreational } \\
\text { Scenario }\end{array}$ & Source \\
\hline \multirow{2}{*}{\multicolumn{6}{|c|}{$\begin{array}{l}\text { Thickness of } \\
\text { material }(\mathrm{m}) \\
\text { Site Specific } \\
\text { Values }\end{array}$}} \\
\hline & & & & & \\
\hline in foundation & 0.15 & 0.15 & NA & NA & $\begin{array}{l}\text { ANL 1993b } \\
\text { p.52 }\end{array}$ \\
\hline $\begin{array}{l}\text { in } \\
\text { contaminated zone } \\
\text { soil }\end{array}$ & 0 & 0 & 0 & 0 & $\begin{array}{l}\text { ANL 1993b } \\
\text { p.52 }\end{array}$ \\
\hline \multirow{2}{*}{\multicolumn{6}{|c|}{$\begin{array}{l}\text { Density of material } \\
\text { (g/cm3) } \\
\text { Site Specific } \\
\text { Values }\end{array}$}} \\
\hline & & & & & \\
\hline $\begin{array}{l}\text { in the } \\
\text { foundation }\end{array}$ & 2.4 & 2.4 & NA & NA & ANL $1993 \mathrm{a}, \mathrm{b}$ \\
\hline $\begin{array}{c}\text { in the } \\
\text { contaminated soil }\end{array}$ & NA & NA & NA & NA & ANL $1993 a, b$ \\
\hline \multirow{2}{*}{\multicolumn{6}{|c|}{$\begin{array}{l}\text { Total porosity of } \\
\text { material } \\
\text { Site Specific } \\
\text { Values }\end{array}$}} \\
\hline & & & & & \\
\hline $\begin{array}{l}\text { in the } \\
\text { foundation }\end{array}$ & 0.1 & 0.1 & NA & NA & $\begin{array}{l}\text { ANL } 1993 b \\
\text { p.44 }\end{array}$ \\
\hline $\begin{array}{c}\text { in the } \\
\text { contaminated soil }\end{array}$ & NA & NA & NA & NA & $\begin{array}{c}\text { ANL } 1993 b \\
\text { p.44 }\end{array}$ \\
\hline \multirow{2}{*}{\multicolumn{6}{|c|}{$\begin{array}{l}\text { Volumetric water } \\
\text { content } \\
\text { Site Specific } \\
\text { Values }\end{array}$}} \\
\hline & & & & & \\
\hline $\begin{array}{l}\text { in the } \\
\text { foundation }\end{array}$ & 0.03 & 0.03 & NA & NA & $\begin{array}{c}\text { RESRAD calc. } \\
\text { ANL 1993b } \\
\text { p.47 }\end{array}$ \\
\hline $\begin{array}{c}\text { in the } \\
\text { contaminated soil }\end{array}$ & NA & $\overline{N A}$ & $\overline{N A}$ & $\overline{N A}$ & $\begin{array}{c}\text { RESRAD calc. } \\
\text { ANL 1993b } \\
\text { p.47 }\end{array}$ \\
\hline
\end{tabular}


Table I-4 (cont.) RESRAD parameters for average exposure case

\begin{tabular}{|c|c|c|c|c|c|}
\hline $\begin{array}{l}\text { RESRAD } \\
\text { Parameters }\end{array}$ & $\begin{array}{l}\text { Commercial } \\
\text { Industrial } \\
\text { Scenario }\end{array}$ & $\begin{array}{l}\text { Suburban } \\
\text { Residential } \\
\text { Scenario }\end{array}$ & $\begin{array}{l}\text { Open Space } \\
\text { Scenario }\end{array}$ & $\begin{array}{l}\text { Recreational } \\
\text { Scenario }\end{array}$ & Source \\
\hline \multirow{2}{*}{\multicolumn{6}{|c|}{$\begin{array}{l}\text { Diffusion coefficient } \\
\text { for radon gas } \\
\text { (m/sec) } \\
\text { Site Specific } \\
\text { Values }\end{array}$}} \\
\hline & & & & & \\
\hline $\begin{array}{r}\text { in the } \\
\text { foundation }\end{array}$ & $3 E-7$ & $3 E-7$ & NA & NA & $\begin{array}{l}\text { ANL 1993b } \\
\text { p.52 }\end{array}$ \\
\hline $\begin{array}{c}\text { in the } \\
\text { contaminated soil }\end{array}$ & $\overline{\mathrm{NA}}$ & NA & NA & NA & $\begin{array}{l}\text { ANL 1993b } \\
\text { p.52 }\end{array}$ \\
\hline $\begin{array}{l}\text { Contamination zone } \\
\text { radon diffusion } \\
\text { coefficient }\end{array}$ & $2 E-6$ & $2 \mathrm{E}-6$ & $2 E-6$ & $2 E-6$ & $\begin{array}{l}\text { ANL 1993b } \\
\text { p.52 }\end{array}$ \\
\hline $\begin{array}{l}\text { Radon vertical } \\
\text { dimension of mixing }\end{array}$ & 2 & 2 & 2 & 2 & $\begin{array}{l}\text { ANL 1993b } \\
\text { p.87 }\end{array}$ \\
\hline $\begin{array}{l}\text { Average annual wind } \\
\text { speed }(\mathrm{m} / \mathrm{sec})\end{array}$ & 6.23 & 6.23 & 6.23 & 6.23 & Nagle 1975 \\
\hline $\begin{array}{l}\text { Average building air } \\
\text { exchange rate }(1 / \mathrm{hr})\end{array}$ & 0.5 & 0.5 & NA & NA & $\begin{array}{l}\text { ANL 1993b } \\
\text { p.89 }\end{array}$ \\
\hline $\begin{array}{l}\text { Height of the } \\
\text { building (room) }(\mathrm{m})\end{array}$ & 2.5 & 2.5 & NA & NA & $\begin{array}{l}\text { ANL 1993b } \\
\text { p.91 }\end{array}$ \\
\hline $\begin{array}{l}\text { Building interior area } \\
\text { factor }\end{array}$ & 0 & 0 & $\overline{N A}$ & $\overline{\mathrm{NA}}$ & $\begin{array}{l}\text { ANL } 1993 \mathrm{~b} \\
\text { p.92 }\end{array}$ \\
\hline $\begin{array}{l}\text { Building depth below } \\
\text { ground surface }(m)\end{array}$ & 1 & 1 & NA & NA & $\begin{array}{l}\text { ANL 1993b } \\
\text { p.95 }\end{array}$ \\
\hline $\begin{array}{l}\text { Emanating power of } \\
R n-222 \text { gas }\end{array}$ & 0.25 & 0.25 & 0.25 & 0.25 & $\begin{array}{l}\text { ANL 1993b } \\
\text { p.58 }\end{array}$ \\
\hline $\begin{array}{l}\text { Emanating power of } \\
\text { Rn-220 gas }\end{array}$ & 0.15 & 0.15 & 0.15 & 0.15 & $\begin{array}{l}\text { ANL 1993b } \\
\text { p.58 }\end{array}$ \\
\hline
\end{tabular}




\section{References}

ANL, 1993a, Manual for Implementing Residual Radioactive Material Guidelines Using RESRAD, Version 5.0. Argonne National Laboratory, Environmental Assessment Division, ANL/EAD/LD-2. September 1993.

ANL, 1993b, Data Collection Handbook to Support Modeling of the Impacts of Radioactive Material in Soil, Argonne National Laboratory, Environmental Assessment and Information Sciences Division. ANL/EAIS-8. September 1993.

BNL, 1995a, Future Land Use Plan (BNL-62130), Brookhaven National Laboratory, Upton, NY.

BNL, 1995b, Brookhaven National Laboratory Draft Remedial Investigation/Risk Assessment Report, Operable Unit IIIV, Vol 2B, Baseline Radiological Risk Assessment, September 21, prepared by CDM Federal Programs Corp, New York, New York.

Central Pine barrens Joint Planning and Policy Commission. 1995. Central Pine Barrens Comprehensive Land Use Plan, Great River, NY.

CDM, 1991, In Situ Soil Treatability Study for the SMS instrument. Camp Dresser and McKee, May 1991.

CDM, 1995a, Brookhaven National Laboratory Final Report Engineering Evaluation/Cost Analysis for Ground Water Operable Unit I, Volume I, Appendix A. CDM Federal Programs Corporation.

CDM, 1995b, Brookhaven National Laboratory Final Feasibility Study for Operable Unit IV, November 10, 1995, CDM Federal Programs Corporation.

DeRosa M.I., Levin, R., 1978, Simulation of Man's Respiratory and Metabolic Functions by the Automated Breathing Metabolic Simulator (IC 8766), U.S. Department of Interior, Bureau of Mines, Washington, D.C.

EPA. 1990. Exposure Factors Handbook (EPA600/8-89/043), Exposure Assessment Group, Office of Health and Environmental Assessment, United States Environmental Protection Agency, Washington, D.C.

EPA, 1991, Risk Assessment Guidance for Superfund - Volume I Human Health Evaluation Manual (Part B Development of Risk-Based Preliminary Remediation Guidelines) Interim Final,. United States Environmental Protection Agency, (285.7-01B). October 1991.

EPA, 1994. EPA Radiation Site Cleanup Regulations Technical Support Document, Volume I, Methods for The Development of Radionuclide Soil Cleanup Levels, United States Environmental Protection Agency, Office of Radiation and Indoor Air, Washington, D.C.

EPA, 1995, Radiation Site Cleanup Regulation 40 CFR 196 (preliminary staff working draft) published in 58 FR 54474, U.S. Environmental Protection Agency, Washington, DC. 
Ershow, A. G. and K.P. Canter. 1989. Total water and tap water intake in the United States: population-based estimates of quantities and sources. Life Sciences Research Office, Federation of American Societies for Experimental Biology.

Fuhrmann, 1995, letter to J. Brower dated April 11, 1995, RE: $K_{d}$ values for Uranium.

IT, 1996, Draft Operable Unit IINII Remedial Investigation Report, September 1996, IT Corporation and Geraghty and Miller, Inc.

Kleinman, M.T. et al.,1980, "Identifying and estimating the relative importance of sources of airborne particulates", Environmental Science and Technology 14: $62-65$.

Nagle, 1975, Climatology of Brookhaven National Laboratory 1949 through 1973, BNL 50466, Brookhaven National Laboratory, Upton, NY 11973.

Nagle, 1978, Climatology of Brookhaven National Laboratory 1974 through 1977 BNL 50857, Brookhaven National Laboratory, Upton, NY 11973.

Neally, 1994, letter to M. Logan (USEPA) and J. Bologna (NYSDEC) dated October 12, 1994, RE: Brookhaven National Laboratory Interagency Agreement (IAG): Operable Unit IV.

Penny, 1994, letter with attachments from Penny (Brookhaven National Laboratory, Upton, NY) to E.R. Faillace (Argonne National Laboratory, Argonne, III.)

SAIC, 1990, Brookhaven National Laboratory Site Baseline Report, November 15, 1990, Science Applications International Corporation.

Sehmel, G.A. 1984. "Deposition and resuspension", Chapter 12 in D. R. Anderson (ed), Atmospheric Science and Power Production, Office of Scientific and Technical Information, U.S. Department of Energy, Washington, DC.

Sheldon, L.S. et al. 1989. An Investigation of linfiltration and Indoor Air Quality: Final Report, New York State Energy Research and Development Authority, Albany, NY.

USGS, 1992, Rates of Water Movement through the Floors of Selected Stormwater Basins in Nassau County, Long Island, New York. U.S. Geological Survey Water Resources Investigations Report.

Warren, M.A., DeLaguna, W., and N.J. Lusczynski, 1968, Hydrology of Brookhaven National Laboratory and Vicinity, Suffolk County, New York. 
Williams, 1995, Comments on draft report entitled "Residual Radioactive Material Guidelines for 13 Radionuclides Present in Operable Unit IV at Brookhaven National Laboratory, Upton, New York, Alexander Williams letter to C. Yu dated May 10, 1995.

Yang, Y-Y and C.B. Nelson, 1984, An Estimation Of The Daily Average Food Intake By Age And Sex For Use In Assessing The Radionuclide Intake Of Individuals in The General Population, Office of Radiation Programs, U.S. Environmental Protection Agency, Washington, DC. 


\section{APPENDIX II: DOCUMENTATION OF RME RESRAD SCENARIO PARAMETERS}

RME scenario characteristics were used to determine remediation guidelines. Average population characteristics should be used in net benefit analyses. The bases for the exposure parameters used in deriving preliminary cleanup guidelines (RME) are given below. Documentation for parameters used in the average exposure case are given in Appendix III.

\section{Exposure Duration (y)}

Commercial/Industrial

25 y EPA reference value (EPA, 1991; 1994).

Residential (Suburban)

30 y EPA reference value (EPA, 1991; 1994).

Open Space (Undeveloped Park Visitor)

30 y Based on EPA reference value for residential use (EPA, 1991; 1994).

Recreation (Developed Park Visitor)

30 y Based on EPA reference value for residential use (EPA, 1991; 1994).

Exposure Frequency $(d / y)$

Note

This is not a RESRAD entry. It is used as the basis for estimating the percentage of time spent indoors and outdoors on site.

Commercial/Industrial

$250 \mathrm{~d} / \mathrm{y}$ This is the value from EPA (1991b). Assumes worker is on site all days of the year except 104 weekend days and 10 additional days (holidays, vacation, sick or other absences).

Residential (Suburban)

$350 \mathrm{~d} / \mathrm{y}$ Assume $15 \mathrm{~d} / \mathrm{y}$ are spent elsewhere (vacation, weekends away, etc.). This is the value from EPA (1991a, b).

Open Space (Undeveloped Park Visitor)

$300 \mathrm{~d} / \mathrm{y} \quad$ A few adult joggers who live near the site may jog or walk on the site almost daily.

Recreation (Developed Park Visitor)

$40 \mathrm{~d} / \mathrm{y} \quad$ Assumes children and adults may engage in sports on site for $40 \%$ of weekends. 


\section{Inhalation Rate $\left(\mathrm{m}^{3} / \mathrm{y}\right)$}

\section{General Approach}

RESRAD operates on this parameter by applying the fraction of time indoors and outdoors, and with a further indoor shielding factor ( 0.8 for gamma rays, 0.4 for airborne particles), but doesn't allow for different inhalation rates indoors and outdoors. An appropriate weighted average value was calculated. Calculations are shown.

DeRosa and Levin (1978) provide inhalation rates by activity (rest, walk, run). The 95th percentile points of the inhalation rate appropriate to the scenario were used. These values are consistent with EPA (1990) Table 3A-2.

\section{Commercial/Industrial}

$7300 \mathrm{~m}^{3} / \mathrm{y} \quad$ From EPA (1991b). This is the total annual breathing rate at 20 $\mathrm{m}^{3} / \mathrm{d}$. This annual value is modified by the parameters fraction of time indoors and outdoors on site.

\section{Residential (Suburban)}

$7300 \mathrm{~m}^{3} / \mathrm{y}$ From EPA $(1991 \mathrm{~b}, 1994)$. This is the total annual breathing rate at $20 \mathrm{~m} / \mathrm{d}$. This is the RESRAD default value.

\section{Open Space (Undeveloped Park Visitor)}

$20,000 \mathrm{~m}^{3} / \mathrm{y}$ Someone jogging on site 1 hour $/ \mathrm{d}, 300 \mathrm{~d} / \mathrm{y}$ is assumed. Based on informal questioning of current joggers at BNL, 1 hour per session is a RME; 300 $\mathrm{d} / \mathrm{y}$ is likely to be too high, but because of limited information, it is taken as an RME. Average inhalation rate while running is $4.9 \mathrm{~m}^{3} / \mathrm{h}$ (DeRosa and Levin, 1978). This level is described by EPA (1990) as considerably higher than crosscountry skiing or playing squash or handball. This yields:

$$
4.9 \mathrm{~m}^{3} / \mathrm{h} \times 24 \times 365=42,924 \mathrm{~m}^{3 / \mathrm{y}}
$$

assuming one breathed at this rate continually for a year. RESRAD will apply the percentage of time outdoors to this factor to reduce it to the number of hours per year jogging on site, i.e., 300 hours

\section{Recreation (Developed Park Visitor)}

$20,000 \mathrm{~m}^{3} / \mathrm{y}$ Assume a weighted average of $25 \%$ running $\left(4.9 \mathrm{~m}^{3} / \mathrm{h}\right), 65 \%$ walking $\left(1.74 \mathrm{~m}^{3} / \mathrm{h}\right)$, and $10 \%$ resting $\left(0.6 \mathrm{~m}^{3} / \mathrm{h}\right)$ during a 4-hour period.

$$
0.25 \times 4.9+0.65 \times 1.74+0.1 \times 0.6=2.42 \mathrm{~m}^{3} / \mathrm{h}
$$

This is equivalent to $58 \mathrm{~m}^{3} / \mathrm{d}$ or $21,199 \mathrm{~m}^{3} / \mathrm{y}$ if this breathing rate were maintained continually. RESRAD will apply the fraction of time outdoors on site to obtain the amount breathed while actually jogging. There is no indoor exposure in this scenario. 


\section{Drinking Water Rate (L/y)}

Commercial/Industrial

$350 \mathrm{~L} / \mathrm{y} \quad$ Based on applying EPA RME (EPA 1991b) value of $1 \mathrm{~L} / \mathrm{d}$ for commercial/industry to $250 \mathrm{~d} / \mathrm{y}$ at work.

Residential (Suburban)

$700 \mathrm{~L} / \mathrm{y} \quad$ RME drinking water consumption in U.S. is $2 \mathrm{~L} / \mathrm{d}$ (Ershow and Cantor, 1989; EPA, 1991b) multiplied by $350 \mathrm{~d} / \mathrm{y}$ in residence.

Open Space (Undeveloped Park Visitor.)

$0 \quad$ No drinking water is supplied.

Recreation (Developed Park Visitor)

$40 \mathrm{~L} / \mathrm{y} \quad$ Based an estimated RME value of $1 \mathrm{~L} / \mathrm{d}$ for 4 hours of recreational activity (assuming that water consumption from an outdoor water fountain or other local source is twice the hourly rate of industrial workers) and multiplying by $40 \mathrm{~d} / \mathrm{y}$.

\section{Mass Loading for Inhalation $\left(\mathrm{g} / \mathrm{m}^{3}\right)$}

\section{General Approach}

Average outdoor respirable particle level in BNL area (based on a study of 20 locations in Suffolk County) was $21.8 \pm 4.5 \mu \mathrm{g} / \mathrm{m}^{3}$ (Sheldon et al, 1989 as reported in EPA, 1995b). The 95th percentile would be $30.8 \mu \mathrm{g} / \mathrm{m}^{3}=$ $3 \times 10^{-5} \mathrm{~g} / \mathrm{m}$. Of this, however, only a fraction originates from soil. Values of that fraction are not available for Suffolk County, but estimates from a study in Portage, WI, found $8.3 \%$ to $16.5 \%$ of respirable particles originated from soil. An earlier study in New York measured $8.3 \pm 4.1$ percent to $37 \pm 18$ percent (Kleinman et al, 1980). Taking the $16.5 \%$ value (second to highest) gives a RME soil mass loading value of $3 \times 10^{-5} \mathrm{~g} / \mathrm{m}^{3} \times 0.165=5 \times 10^{-6} \mathrm{~g} / \mathrm{m}^{3}$. This approximates the lower end of the range $9 \times 10^{-6}$ to $7.9 \times 10^{-5}$ suggested in ANL (1993a). Most values of resuspension rates in the literature are from sites such as the Nevada Test Site and Hanford, where there is little vegetative cover and thus a high rate of wind resuspension. These rates are expressed in units of $\mathrm{g} / \mathrm{m}^{3}$ per $\mathrm{g} / \mathrm{m}^{2}$ which reduces to $\mathrm{m}^{-1}$. For example, these values often range as high as $10^{-5}$ or $10^{-4} \mathrm{~m}^{-1}$ compared to values measured in New York that range $10^{-9}$ to $10^{-8} \mathrm{~m}^{-1}$ (Sehmel, 1984). These differences also support the use of the low end of the ANL (1993a) range. 
Commercial/Industrial

$1 \times 10^{-4} \mathrm{~g} / \mathrm{m}^{3}$ This value is an order of magnitude higher than discussed above. The higher value that is used $\left(1 \times 10^{-4} \mathrm{~g} / \mathrm{m}^{3}\right)$ appears to have been based on desert conditions at the Nevada Test Site, although it is also attributed to "... sustained periods of normal farmyard activities..." (ANL, 1993a). The use of the higher value was required by EPA and provides an order of magnitude factor of safety to this parameter.

Residential (Suburban)

$1 \times 10^{-4} \mathrm{~g} / \mathrm{m}^{3}$ This value is an order of magnitude higher than discussed above. The higher value that is used $\left(1 \times 10^{-4} \mathrm{~g}^{3} \mathrm{~m}^{3}\right)$ appears to have been based on desert conditions at the Nevada Test Site, although it is also attributed to "... sustained periods of normal farmyard activities..." (ANL, 1993a). The use of the higher value was required by EPA and provides an order of magnitude factor of safety to this parameter.

\section{Open Space (Undeveloped Park Visitor)}

The Open Space value was identical to the Commercial/Industrial and Residential Scenarios above.

Recreation (Developed Park Visitor)

$2 \times 10^{-4} \mathrm{~g} / \mathrm{m}^{3}$ The same as for open space scenario (above), except that the value is doubled to account for the increased activity resulting in an increase in the amount of airborne dust.

\section{Shielding Factor, Inhalation}

Commercial/Industrial

0.4 ANL 1993b, p. 112. This is the RESRAD default.

Residential (Suburban)

0.4 ANL 1993b, p. 112. This is the RESRAD default.

\section{Open Space (Undeveloped Park Visitor)}

1.0 All inhalation exposure is outdoors.

Recreation (Developed Park Visitor)

1.0 All inhalation exposure is outdoors.

\section{Shielding Factor, External Gamma}

Commercial/Industrial

$0.8 \quad$ ANL 1993b, p. 129.

Residential (Suburban)

$0.8 \quad$ ANL 1993b, p. 129. 


\title{
Open Space (Undeveloped Park Visitor)
}

\author{
$1.0 \quad$ All exposure is outdoors.
}

Recreation (Developed Park Visitor)
1.0
All exposure is outdoors.

\section{Fraction of Time Spent Indoors}

\section{General Approach}

This refers to the fraction of time spent indoors on-site. Exposure to direct radiation and contaminated wind-blown dust from outdoors is lower when indoors.

\section{Commercial Industrial}

0.06 Assumes workers are on site $250 \mathrm{~d} / \mathrm{y}$ (EPA, 1991b). That is, they work the equivalent of 50 weeks $/ \mathrm{y}, 40 \mathrm{~h} / \mathrm{wk}$. Assumed workers spend $26 \%$ of their working time (about 2 hours) indoors and 75\% (about 6 hours) outdoors on site. This assumes workers spend all their time other than 40 hours per week off the site. Since exposures are higher outdoors, the RME worker is one who spends most of his time outdoors. A typical worker might be expected to spend a much higher proportion of work time indoors. It should be noted that, where sources of radon gas are involved, the exposure rate indoors may be higher than the exposure rate outdoors. Indoor radon exposures, however, if present, are usually sufficiently high to overwhelm any occupancy fraction bias. EPA required use of this value for the RME scenario.

\section{Residential (Suburban)}

0.50 Residents spend $350 \mathrm{~d} / \mathrm{y}$ on site. This assumes 15 days are spent elsewhere, e.g., vacation, weekends away, etc. (EPA, 1991b). Of the 350 days in residence on site, $50 \%$ of time is assumed to be spent indoors at residence, $25 \%$ outdoors at residence, and $25 \%$ away from the site. Spending $50 \%$ of one's time indoors at home is equivalent to $84 \mathrm{~h} / \mathrm{wk}$. Most people spend a higher percentage of their time at home indoors. Since exposure rates are generally higher outdoors, the RME individual is assumed to spend a higher than average fraction of time at home outdoors. It should be noted that, where sources of radon gas are involved, the exposure rate indoors may be higher than the exposure rate outdoors. Indoor radon exposures, however, if present, are usually sufficiently high to overwhelm any occupancy fraction bias.

\section{Open Space (Undeveloped Park Visitor)}

All time spent outdoors.

Recreation (Developed Park Visitor)

$0 \quad$ All time spent outdoors. 


\section{Fraction Of Time Spent Outdoors}

\section{General Approach}

This refers to the fraction of time spent outdoors on-site. Exposure to direct radiation and contaminated wind-blown dust is higher outdoors than indoors.

Commercial/Industrial

0.17 Assumes workers are on site $250 \mathrm{~d} / \mathrm{y}$ (EPA, 1991b). That is, they work the equivalent of 50 weeks $/ y, 40 \mathrm{~h} / \mathrm{wk}$. The RME worker is assumed to spend $75 \%$ of work time outdoors and $25 \%$ indoors. This is because outdoor exposures are generally higher. Workers spend all their time other than 40 hours per week off the site.

\section{Residential (Suburban)}

0.25 Of the 350 days in residence on site, $50 \%$ of time assumed to be spent indoors at residence, $25 \%$ outdoors at residence, and $25 \%$ away from the site. $25 \%$ of the time outdoors is equivalent to $6 \mathrm{~h} / \mathrm{d}$ outdoors on weekend days and 2 h/d outdoors on weekdays. Thus, the RME value represents a person who spends an unusual amount of time outdoors at home where the exposure to direct radiation and to contaminated dust is higher.

\section{Open Space (Undeveloped Park Visitor)}

0.073 A jogger is assumed to spend 1 hour/d for $300 \mathrm{~d} / \mathrm{y}$ on site, all outdoors. The fraction of time outdoors on site is thus:

$$
300 / 8760=0.034
$$

The jogger spends fewer hours per year on site than was assumed for the visitor in BNL (1995), but, based on the calculations shown above, even this estimate seems high. Moreover, the jogger has a higher breathing rate, so inhalation exposure is higher than in BNL (1995).

RESRAD applies this fraction of time outdoors to the breathing rate in its calculation of the total volume of contaminated air inhaled per year jogging on site.

For comparison, the Fernald Environmental Management Project, in their final draft Remedial Investigation report (USDOE, 1994) assumed adults spent $2 \mathrm{~h} / \mathrm{d}$ for $40 \mathrm{~d} / \mathrm{y}$, or $80 \mathrm{~h} / \mathrm{y}$ (fraction of time $=0.009$ ) in their undeveloped park scenario. Although we assume no camping would be allowed, one might consider how the selection of the dedicated jogger compares to a camper. Someone camping for two weeks on site would be there for 14 days $\times 24 \mathrm{~h} / \mathrm{d}=336 \mathrm{~h} / \mathrm{y}$, compared to the $300 \mathrm{~h} / \mathrm{y}$ for the jogger, who has a higher breathing rate. Thus, even if someone were to camp on the site, their exposure time would not be significantly different from the scenario assumptions. 


\section{Recreation (Developed Park Visitor)}

0.032 The RME person is assumed to be a youth who engages in sports or related activities on site for $104 \mathrm{~d} / \mathrm{y}$, all outdoors, for an average of $4 \mathrm{~h} / \mathrm{d}$. This is based on Fernald Environmental Management Project (FEMP), final draft Remedial Investigation report (USDOE, 1994). Youth (7 to 18) compose the highest exposure group. Since people are considered to be children only for 10 years, however, while we consider a 30 year exposure duration, an ageaveraged value is estimated. FEMP estimates children under 6 to visit the park $64 \mathrm{~d} / \mathrm{y}$ for $4 \mathrm{hrs} / \mathrm{d}$ and adults for $40 \mathrm{~d} / \mathrm{y}$ for $4 \mathrm{~h} / \mathrm{d}$. The age-weighted average is:

$(64 \mathrm{~d} / \mathrm{y} \times 4 \mathrm{~h} / \mathrm{d} \times 6 \mathrm{y}+104 \mathrm{~d} / \mathrm{y} \times 4 \mathrm{~h} / \mathrm{d} \times 10 \mathrm{y}+40 \mathrm{~d} / \mathrm{y} \times 4 \mathrm{hr} / \mathrm{d} \times 14 \mathrm{y}) / 30 \mathrm{y}$

$$
=265 \text { hrs } / y \text {. }
$$

$265 \mathrm{hrs} / \mathrm{y} / 8760=0.03$ fraction of time outdoors on site.

RESRAD applies this fraction of time outdoors to the breathing rate in its calculation of the total volume of contaminated air inhaled per year jogging on site.

\section{Fruits, Vegetables, Grain Consumption (total) (kg/y)}

\section{General Approach}

This parameter estimates the total amount of food consumed in this category. RESRAD then adjusts this factor by the fraction of food that is home grown. The RESRAD default value is $160 \mathrm{~kg} / \mathrm{y}$. Yang and Nelson (1984) estimated daily average food intake by category and subcategory for use in estimating radionuclide intake of individuals in the general population. They estimated total intake of produce (other than leafy vegetables) and grains at $162 \mathrm{~kg} / \mathrm{y}$, the RESRAD default.

Commercial/Industrial

0

No produced grown in industrial or commercial area.

Residential (Suburban)

$160 \mathrm{~kg} / \mathrm{y}$ The RESRAD default (see also general approach, above).

Open Space (Undeveloped Park Visitor)

$160 \mathrm{~kg} / \mathrm{y}$ The RESRAD default. This category is included in the open space scenario because of the possibility that visitors may collect mushrooms or berries.

\section{Recreation (Developed Park Visitor)}

$0 \quad$ No edible material assumed to be grown in a recreational area. 


\section{Leafy Vegetable Consumption (kg/y)}

\section{General Approach}

This parameter estimates the total consumption of leafy vegetables. RESRAD then adjusts this factor by the fraction of food that is home grown. The RESRAD default value is $14 \mathrm{~kg} / \mathrm{y}$. Yang and Nelson (1984) estimated daily average food intake by category and subcategory for use in estimating radionuclide intake of individuals in the general population. They estimated total intake of leafy vegetables at $14 \mathrm{~kg} / \mathrm{y}$. This value is the RESRAD default.

\section{Commercial/Industrial}

0 No edible material assumed to be grown in commercial or industrial areas.

Residential (Suburban)

$14 \mathrm{~kg} / \mathrm{y}$ RESRAD default.

\section{Open Space (Undeveloped Park Visitor)}

$0 \quad$ No leafy vegetable consumption.

\section{Recreation (Developed Park Visitor)}

$0 \quad$ No edible material assumed to be grown in recreational area.

\section{Contaminated Fraction of Plant Food}

Commercial/Industrial

$0 \quad$ No produce grown in industrial or commercial area.

\section{Residential (Suburban)}

0.2 The bulk of food consumption from plants is from the category "fruits, vegetables, and grains" (160 kg/y out of a total of $174 \mathrm{~kg} / \mathrm{y})$. Yang and Nelson (1984) estimated daily average food intake by category and subcategory for use in estimating radionuclide intake of individuals in the general population. Grains, however, make up $45 \%$ of the category "fruits, vegetables, and grains." Suburban families on Long Island do not grow grains. It is assumed in this suburban residential scenario that no grains are home grown. That reduces the total annual consumption from the RESRAD default of $160 \mathrm{~kg} / \mathrm{y}$ to $89 \mathrm{~kg} / \mathrm{y}$. Citrus fruits also fall into this category. None are home grown in the BNL area. Based on a 3-day survey, EPA (1990) estimated $50 \mathrm{~kg} / \mathrm{y}$ of citrus fruits in this category. The overall estimate for the category "Protected Produce" in EPA (1990) in which citrus fruits fell, however, was 8.7 times higher than values from Yang and Nelson (1984) (also an EPA document). Applying the percentage fraction of citrus fruit to the Yang and Nelson number yields $16 \mathrm{~kg} / \mathrm{y}$ for citrus fruit. This leaves only $73 \mathrm{~kg} / \mathrm{y}$ in the fruit, produce and grain category that could possibly be grown in home gardens. Applying the EPA default value for the fraction of home grown vegetables $(0.4)$ and fruits $(0.3)$ to the vegetables that could be home grown on Long Island, i.e., $14.3 \mathrm{~kg} / \mathrm{y}$ leafy vegetables, $31.4 \mathrm{~kg} / \mathrm{y}$ 
exposed produce (of which $69 \%$ is fruit and $31 \%$ vegetables) and $39 \mathrm{~kg} / \mathrm{y}$ protected produce, yields $25 \mathrm{~kg} / \mathrm{y}$ vegetables and $6.5 \mathrm{~kg} / \mathrm{y}$ fruit, or $20 \%$ of the $160 \mathrm{~kg} / \mathrm{y}$ total intake.

\section{Open Space (Undeveloped Park Visitor)}

0.006 Assumes possibility that visitor may collect mushrooms or berries. Since neither are plentiful in the area, assume RME individual collects $1 \mathrm{~kg} / \mathrm{y}$ out of total fruit, vegetable and grain category of $160 \mathrm{~kg} / \mathrm{y}$. The factor is also applied automatically to leafy vegetables category also; this might be associated with picking fresh salad greens.

\section{Recreation (Developed Park Visitor)}

$0 \quad$ Assumes no edible material is grown in recreational area.

\section{Meat Consumption (kg/y)}

\section{General Approach}

It is assumed that because of the suburban nature of the area, no livestock will be kept on site and no hunting allowed in residential or commercial/industrial areas. Therefore, no meat will be produced. In the open space scenario, however, hunting may be allowed (or poachers may hunt illegally). In this scenario, an exposure pathway through eating wild game is included.

\section{Commercial/Industrial}

0 No meat production or hunting in commercial or industrial areas.

Residential (Suburban)

$0 \quad$ No meat production or hunting in residential areas.

\section{Open Space (Undeveloped Park Visitor)}

$63 \mathrm{~kg} / \mathrm{y}$ Total of beef, pork and other meat from all sources (RESRAD default). Yang and Nelson (1984) use $51.1 \mathrm{~kg} / \mathrm{y}$.

\section{Recreation (Developed Park Visitor)}

$0 \quad$ No hunting in recreational area.

\section{Contaminated Fraction of Meat Consumption}

\section{Commercial/Industrial}

0 No meat production or hunting in commercial or industrial areas.

\section{Residential (Suburban)}

0 No meat production or hunting in residential areas. 


\section{Open Space (Undeveloped Park Visitor)}

0.14 Since deer meat is the only contaminated meat consumed and, for the RME case, all deer meat consumed is assumed to come from the site, this is the fraction of deer meat to total meat. Deer meat consumption is assumed to be $8.85 \mathrm{~kg} / \mathrm{y}$. This is the extreme upper end of a range from 1.35 to $8.85 \mathrm{~kg} / \mathrm{y}$ (Davis, 1995). The RESRAD default value for total meat in the diet is $63.4 \mathrm{~kg} / \mathrm{y}$ (ANL, 1993a); the ratio of deer meat is thus 8.85/63.4 $=0.14$.

\section{Recreation (Developed Park Visitor)}

$0 \quad$ No hunting in recreational area.

\section{Soil Ingestion Rate ( $g / y)$}

\section{General Approach}

Both adults and children ingest small amounts of soil. Commercial exposures assume only adults, residential exposures assume children. Since people do not remain children for the 30 years of residence assumed, a weighted exposure over 30 years was calculated for the residential scenario.

\section{Commercial/Industrial}

$36.5 \mathrm{~g} / \mathrm{y} \quad$ Based on $100 \mathrm{mg} / \mathrm{d}$ (EPA, 1991b, RME value for adults).

$$
100 \mathrm{~g} / \mathrm{d} \times 365 \mathrm{~d} / \mathrm{y}=36.5 \mathrm{~g} / \mathrm{y}
$$

RESRAD applies the fraction of time indoors and outdoors on site to this number.

\section{Residential (Suburban)}

$43.8 \mathrm{~g} / \mathrm{y} \quad$ Assuming a 30 year residence beginning at birth, the annual average RME exposure is calculated as 6 years at $200 \mathrm{mg} / \mathrm{d}$ and 24 years at $100 \mathrm{mg} / \mathrm{d}$ (EPA, 1991b) for 365 days per year.

$$
[(0.2 \mathrm{~g} / \mathrm{d} \times 6 \mathrm{y})+(0.1 \mathrm{~g} / \mathrm{d} \times 24 \mathrm{y})] \times 365 \mathrm{~d} / \mathrm{y} / 30 \mathrm{y}=43.8 \mathrm{~g} / \mathrm{y}
$$

RESRAD applies the fraction of time indoors and outdoors on site to this number.

Open Space (Undeveloped Park Visitor)

$36.5 \mathrm{~g} / \mathrm{y} \quad$ Based on $100 \mathrm{mg} / \mathrm{d}$ (EPA, 1991b, RME value for adults).

$$
100 \mathrm{~g} / \mathrm{d} \times 365 \mathrm{~d} / \mathrm{y}=36.5 \mathrm{~g} / \mathrm{y}
$$

RESRAD applies the fraction of time indoors and outdoors on site to this number. 


\section{Recreation (Developed Park Visitor)}

$65.7 \mathrm{~g} / \mathrm{y}$ Assuming a 30 year residence beginning at birth, the annual average RME exposure is calculated as 6 years at $200 \mathrm{mg} / \mathrm{d}$ and 24 years at $100 \mathrm{mg} / \mathrm{d}$ (EPA, 1991) for 365 days per year. The result is then increased by $50 \%$ to account for the greater possibility of contact with soil in sport.

$$
1.5 \text { * }[(0.2 \mathrm{~g} / \mathrm{d} \times 6 \mathrm{y})+(0.1 \mathrm{~g} / \mathrm{d} \times 24 \mathrm{y})] \times 365 \mathrm{~d} / \mathrm{y} / 30 \mathrm{y}=65.7 \mathrm{~g} / \mathrm{y}
$$

RESRAD applies the fraction of time indoors and outdoors on site to this number.

\section{Mass Loading for Foliar Deposition $\left(\mathrm{g} / \mathrm{m}^{3}\right)$}

Commercial/Industrial

Not used since exposure through ingestion of plants is not applicable to the commercial/industrial scenario.

\section{Residential (Suburban)}

$1 \times 10^{-4} \mathrm{~g} / \mathrm{m}^{3} \quad$ Average outdoor respirable particle level in BNL area (based on a study of 20 locations in Suffolk County) was $21.8 \pm 4.5 \mu \mathrm{g} / \mathrm{m}^{3}$ (Sheldon et al, 1989 as reported in EPA, 1995b). The 95th percentile would be $30.8 \mu \mathrm{g} / \mathrm{m}^{3}=3$ $\times 10^{-5} \mathrm{~g} / \mathrm{m}^{3}$. Of this, however, only a fraction originates from soil. Values of that fraction are not available for Suffolk County, but estimates from a study in Portage, WI, found $8.3 \%$ to $16.5 \%$ of respirable particles originated from soil. An earlier study in New York measured $8.3 \pm 4.1$ percent to $37 \pm 18$ percent (Kleinman et al, 1980). Taking the $16.5 \%$ value (second to highest) gives a RME soil mass loading value of $3 \times 10^{-5} \mathrm{~g} / \mathrm{m}^{3} \times 0.165=5 \times 10^{-6} \mathrm{~g} / \mathrm{m}^{3}$. This approximates the lower end of the range $9 \times 10^{-6}$ to $7.9 \times 10^{-5}$ suggested in ANL (1993). Most values of resuspension rates in the literature are from sites such as the Nevada Test Site and Hanford, where there is little vegetative cover and thus a high rate of wind resuspension. These rates are expressed in units of $\mathrm{g} / \mathrm{m}^{3}$ per $\mathrm{g} / \mathrm{m}^{2}$ which reduces to $\mathrm{m}^{-1}$. For example, these values often range as high as $10^{-5}$ or $10^{-4} \mathrm{~m}^{-1}$ compared to values measured in New York that range $10^{-9}$ to $10^{-8} \mathrm{~m}^{-1}$ (Sehmel, 1984). These differences also support the use of the low end of the ANL (1993a) range. While a value of $5 \times 10^{-6} \mathrm{~g} / \mathrm{m}^{3}$ appears supportable, to assure a value consistent with the RME and to keep within the range given in ANL (1993a), that value is doubled to $1 \times 10^{-5} \mathrm{~g} / \mathrm{m}^{3}$. The higher value used $\left(1 \times 10^{-4} \mathrm{~g} / \mathrm{m}^{4}\right)$ was required by EPA and provides an order of magnitude factor of safety to this parameter.

\section{Open Space (Undeveloped Park Visitor)}

$1 \times 10^{-4} \mathrm{~g} / \mathrm{m}^{3}$ Same as in the Residential Scenario, above. In addition, note that in this scenario, essentially all the site will have vegetation cover. 
Recreation (Developed Park Visitor)

$1 \times 10^{-4} \mathrm{~g} / \mathrm{m}^{3}$ Same as residential Scenario, above. This could be slightly higher to be consistent with estimate of soil inhalation, but has no effect since no vegetation is consumed from the site.

\section{Livestock Fodder (applied to deer) (kg/d)}

\section{General Approach}

This applies only to the open space scenario since other scenarios do not permit hunting or raising of livestock.

\section{Open Space Scenario}

$68 \mathrm{~kg} / \mathrm{d} \quad$ Radionuclide contaminated soil on the site constitutes less than $2 \%$ of the land area of the BNL site. It initially seemed reasonable to assume that radioactively contaminated areas are randomly selected in the grazing area. Thus it was assumed initially that contamination in the deer meat should be only $2 \%$ of that which would be expected were the deer to graze only on radioactively contaminated areas. Since the RESRAD default intake is $68 \mathrm{~kg} / \mathrm{d}$, correcting for the $2 \%$ factor yields $68 \mathrm{~kg} / \mathrm{d} \times 0.02=1.36$. Much of the area contaminated with radionuclides is landscaping soil containing Cs-137. This area is covered with grass and is attractive to deer. Although deer clearly do much of their grazing on non-contaminated soils, the appropriate values should be above $1.36 \mathrm{~kg} / \mathrm{d}$. EPA required that the full $68 \mathrm{~kg} / \mathrm{d}$ be used. Note that the RESRAD default value of $68 \mathrm{~kg} / \mathrm{d}$ applies to cattle, not deer. The difference in mass per day is not relevant, since it is normalized to the amount of meat consumed. There is a potential difference, however, in the uptake coefficient due to differences in how the animals feed or how they metabolize the cesium.

\section{Livestock (deer) Intake of Soil (kg/d)}

\section{General Approach}

This applies only to the open space scenario since other scenarios do not permit hunting.

$0.5 \mathrm{~kg} / \mathrm{d}$ The RESRAD default value for cattle is $0.5 \mathrm{~kg} / \mathrm{d}$. In this case, there are no cattle; this part of RESRAD is used to estimate the intake of deer.

Further improvements can be made to the estimate of dose through this pathway. For example, deer eat considerably less soil than cattle.

\section{Precipitation}

$1.23 \mathrm{~m} / \mathrm{y} \quad$ Based on on-site measurements at BNL 1949-95 (Nagle, 1975, 1978; Cassella, 1996).

\section{Average Wind Speed}

$6.23 \mathrm{~m} / \mathrm{s} \quad$ Based on on-site measurements at BNL 1949-95 (Nagle, 1975 , 1978; Cassella, 1996). 


\section{References}

ANL, 1993a, Manual for Implementing Residential Radioactive Material Guidelines Using RESRAD, Version 6.0 (ANL/EAD/LD-2), C. Yu et al., Argonne National Laboratory, Argonne, IL.

ANL, 1993b, Data Collection Handbook to Support Modeling the Impacts of Radioactive Material in Soil (ANL/EIAS-8), Argonne National Laboratory, Argonne, IL.

BNL, 1995, Brookhaven National Laboratory Draft Remedial Investigation/Risk Assessment Report, Operable Unit IIIV, Vol. 2B, Baseline Radiological risk Assessment, September 21. Prepared by CDM Federal Programs Corp. New York, New York.

Cassella, V. 1996. personal communication with B. Dionne.

Collopy, P. 1995. Brookhaven National Laboratory Draft Remedial Investigation/Risk Assessment Report Operable Unit INI, Vol. 2B, Baseline Radiological Risk Assessment, CDM Federal Programs Corp., New York.

Davis, M.S. 1995. Memo to H. Knoch, NYSDEC, May 15.

DeRosa M.I, Levin, R. 1978. Simulation of Man's Respiratory and Metabolic Functions by the Automated Breathing Metabolic Simulator (IC 8766), U.S. Department of Interior, Bureau of Mines, Washington, D.C.

EPA. 1990. Exposure Factors Handbook (EPA/600/8/043), Exposure Assessment Group, Office of Health and Environmental Assessment, USEPA, Washington, D.C.

EPA. 1991a. Standard Default Exposure Factors, EPA OSWER Directive 9285.6-03, March 25, 1991.

EPA, 1991b, Risk Assessment Guidance for Superfund - Volume I Human Health Evaluation Manual (Part B Development of Risk-Based Preliminary Remediation Guidelines) Interim Final,. United States Environmental Protection Agency. (285.7-01B). October 1991.

EPA. 1993. Superfund's Standard Default Exposure Factors for the Central Tendency and Reasonable Maximum Exposure, Review Draft, 4 Nov. (from Rocky Flats, 1995)

EPA. 1994. EPA Radiation Site Cleanup Regulations Technical Support Document: Vol. I; Methods for the development of radionuclide soil cleanup levels (preliminary review draft), prepared by S. Cohen \& Associates for U.S. Environmental Protection Agency, Office of Radiation and Indoor Air, Washington, D.C. March.

EPA, 1995a, Radiation Site Cleanup Regulation 40 CFR 196 (preliminary staff working draft) published in 58 FR 54474, U.S. Environmental Protection Agency, Washington, DC. 
EPA. 1995b. Air Quality Criteria for Particulate Matter (Review Draft) Vol. 1 (EPA600/AP/001a, April 1995), Office of Research and Development, U.S. Environmental Protection Agency, Washington, D.C.

Ershow, A. G. and K.P. Canter. 1989. Total Water And Tap Water Intake In The United States: Population-Based Estimates Of Quantities And Sources. Life Sciences Research Office, Federation of American Societies for Experimental Biology.

Kleinman, M.T. et al. 1980. "Identifying And Estimating The Relative Importance Of Sources Of Airborne Particulates", Environmental Science and Technology 14: $62-65$.

Nagle, C.M. 1975, Climatology of Brookhaven National Laboratory 1949 through 1973 (BNL 50466), Brookhaven National Laboratory, Upton, NY 11973.

Nagle, C.M. 1978, Climatology of Brookhaven National Laboratory 1974 through 1977 (BNL 50857), Brookhaven National Laboratory, Upton, NY 11973.

Santana, S. et al. 1990. "Particulate Matter Exposures Estimated From an Indoor-Outdoor Source Apportionment Study ", in: Indoor Air '90: Proceedings of the 5th International Conference on Indoor Air Quality and Climate, Vol. 2, Characteristics of Indoor Air, Ottawa Canada, pp. 583-588.

Sehmel, G.A. 1984. "Deposition and Resuspension", Chapter 12 in D. R. Anderson (ed), Atmospheric Science and Power Production, Office of Scientific and Technical Information, U.S. Department of Energy, Washington, D.C.

Sheldon, L.S. et al. 1989. An Investigation of Infiltration and Indoor Air Quality: Final Report, New York State Energy Research and Development Authority, Albany, N.Y.

Yang, Y; Nelson, C.B. 1984., An Estimation of the Daily Average Food Intake by Age and Sex for Use in Assessing the Radionuclide Intake of Individuals in the General Population, U.S. Environmental Protection Agency, Office of Radiation Programs, Washington, D.C. 


\section{APPENDIX III: DOCUMENTATION OF RESRAD PARAMETERS FOR AVERAGE EXPOSURE SCENARIOS}

Average population scenario characteristics are used to estimate total cumulative dose to the population.

\section{Exposure Duration ( $y$ )}

Commercial/Industrial

25 y EPA reference value (EPA, 1991; 1994).

Residential (Suburban)

30 y EPA reference value (EPA, 1991; 1994).

Open Space (Undeveloped Park Visitor)

30 y Based on EPA reference value for residential use (EPA, 1991; 1994).

Recreation (Developed Park Visitor)

30 y Based on EPA reference value for residential use (EPA, 1991; 1994).

\section{Exposure Frequency (d/y) and Number of People}

Note

This is not a RESRAD entry. It is used as the basis for estimating the percentage of time spent indoors and outdoors on site. Number of people is needed to estimate population exposure (person-rem).

\section{Commercial/Industrial}

$250 \mathrm{~d} / \mathrm{y}$ Employees exposed 8-h/d for the work-year. Commercial buildings average 0.0013 workers $/ \mathrm{ft}^{2}$ ( 1400 workers $\left./ \mathrm{km}^{2}\right)$ (DOE, 1995). The buildings take up, perhaps, less than half of the land area, but customers or other visitors increase the number of people exposed. In the absence of other data the 1400 people $/ \mathrm{km}^{2}$ value is suggested.

Residential (Suburban)

$350 \mathrm{~d} / \mathrm{y}$ Assume families on 1/2-acre lots, 3.2 people per family (1990 US average). That is 6.4 people/acre (1581 people/km²). Assume $15 \mathrm{~d} / \mathrm{y}$ are spent elsewhere (vacation, weekends away, etc.). EPA (1995) assumes 1,000 people $/ \mathrm{km}^{2}$ ( 4 people/acre) as a high density scenario.

\section{Open Space (Undeveloped Park Visitor)}

$3 \mathrm{~d} / \mathrm{y} \quad$ Families or individuals visiting the park a few days a year, spending about 4 hours per visit. Estimate 2.5 annual visitors per acre (600 annual visitors $/ \mathrm{km}^{2}$ ). This is an average of 1.6 visitors $/ \mathrm{d} / \mathrm{km}^{2}$. This is the average of the NYS Rocky Point Natural Resources Management Area (5154 acres, 15,000 visitors/y) and the Navy Cooperative area (4026 acres, 8,000 visitors/y). The BNL site is physically close to these two properties and will have similar uses. In both cases, visitor activities are hunting, hiking, nature observation, cross- 
country skiing. Access permits are required for the Rocky Point Property; 4000 permits are issued annually. If 5000 people are assumed to use the property, 15000 visits $/ 5000$ people $=3$ days per year per person. The number of visitordays may be an overestimate for the current population, since the current visitors to the Rocky Point and Navy properties may simply be split among the three properties. Increasing population in the surrounding area, however, is likely to increase overall visits.

\section{Recreation (Developed Park Visitor)}

$20 \mathrm{~d} / \mathrm{y}$ RME value was $40 \mathrm{~d} / \mathrm{y}$, on the assumption that some adults may engage in sports on site for $40 \%$ of weekends (FEMP assumed $40 \mathrm{~d} / \mathrm{y}$ for adults). RME assumed $4 \mathrm{~h} / \mathrm{d}$. Assume average is one-half the number of days per year as the RME but that the $4 \mathrm{~h} / \mathrm{d}$ still applies. The Red Creek Park in nearby Hampton Bays is largely developed. It is 40 acres, within a range of what might be a developed park on the BNL site, and receives an average of 500 visitors $/ \mathrm{d} / \mathrm{km}^{2}$.

\section{Inhalation Rate $\left(\mathrm{m}^{3} / \mathrm{d}\right)$}

\section{General Approach}

DeRosa and Levin (1978) provide average inhalation rates by activity (rest, walk, run).

\section{Commercial//ndustrial}

$7300 \mathrm{~m}^{3} / \mathrm{y}$ From EPA (1991b). This is the total annual breathing rate at 20 $\mathrm{m}^{3} / \mathrm{d}$. This annual value is modified by the parameters fraction of time indoors and outdoors on site.

\section{Residential (Suburban)}

$7300 \mathrm{~m}^{3} / \mathrm{y}$ From EPA (1991b). This is the total annual breathing rate at 20 $\mathrm{m}^{3} / \mathrm{d}$. This annual value is modified by the parameters fraction of time indoors and outdoors on site.

\section{Open Space (Undeveloped Park Visitor)}

$15000 \mathrm{~m}^{3} / \mathrm{y}$ Average adult inhalation while walking is $1.7 \mathrm{~m}^{3} /$ hour for $4 \mathrm{~h} / \mathrm{d}$, or $7.0 \mathrm{~m}^{3} / \mathrm{d}, 3 \mathrm{~d} / \mathrm{y}$. Since RESRAD applies the fraction of time outdoors on site, the required number is as if this rate were continuous, $1.7 \mathrm{~m}^{3} / \mathrm{hour} \times 8760 \mathrm{hr} / \mathrm{y}=$ $14,892 \mathrm{~m}^{3} / \mathrm{y}$. For child, assume $50 \%$ walking, $50 \%$ running.

\section{Recreation (Developed Park Visitor)}

$20,000 \mathrm{~m}^{3} / \mathrm{y}$ Assume weighted average of $25 \%$ running $\left(4.87 \mathrm{~m}^{3} / \mathrm{h}\right), 65 \%$ walking $\left(1.74 \mathrm{~m}^{3} / \mathrm{h}\right)$, and $10 \%$ resting $\left(0.6 \mathrm{~m}^{3} / \mathrm{h}\right)$. Total is $2.4 \mathrm{~m}^{3} / \mathrm{h}$ or $9.6 \mathrm{~m}^{3}$ during a 4-hour period in a day. Since RESRAD applies the fraction of time outdoors on site, the required number is as if this rate were continuous, 2.4 $\mathrm{m}^{3} /$ hour $\times 8760 \mathrm{hr} / \mathrm{y}=21,024 \mathrm{~m}^{3} / \mathrm{y}$. Since RESRAD has a quality control check that forbids entries above $20,000 \mathrm{~m}^{3} / \mathrm{y}$, the estimate is rounded down to that value. 


\section{Drinking Water Rate (L/y) \\ Commercial/Industrial}

$150 \mathrm{~L} / \mathrm{y}$ Based on applying the ratio of mean to RME for residential drinking water consumption (1.2 L/d vs. 2 L/d; EPA 1991b) to the 1 L/d EPA RME value for commercial/industry and multiplying by $250 \mathrm{~d} / \mathrm{y}$.

\section{Residential (Suburban)}

$420 \mathrm{~L} / \mathrm{y}$ Average drinking water consumption in U.S. is $1.2 \mathrm{~L} / \mathrm{d}$ (Ershow and Cantor, 1989) multiplied by $350 \mathrm{~d} / \mathrm{y}$ in residence.

Open Space (Undeveloped Park Visitor)

$0 \quad$ No drinking water is supplied.

Recreation (Developed Park Visitor)

$12 \mathrm{~L} / \mathrm{y} \quad$ Based on applying the ratio of mean to RME for residential drinking water consumption to the $1 \mathrm{~L} /$ d estimated as the RME value for 4 hours of recreational activity $(1.2 \mathrm{~L} / \mathrm{d}$ vs. $1 \mathrm{~L} / \mathrm{d})$, and multiplying by $20 \mathrm{~d} / \mathrm{y}$.

\section{Mass Loading for Inhalation $\left(\mathrm{g} / \mathrm{m}^{3}\right)$ (same as RME)}

Commercial/Industrial

$1 \times 10^{-5} \mathrm{~g} / \mathrm{m}^{3}$ Average particle level in Brookhaven area about $40 \mu \mathrm{g} / \mathrm{m}^{3}=4 \mathrm{x}$ $10^{-5} \mathrm{~g} / \mathrm{m}^{3}$ of which less than $25 \%$ comes from entrainment of soil from site, given essentially all the site will have vegetation cover. While an industrial area might generate a higher particulate level, it would not be from contaminated soil. Note EPA usually assumes $1 \times 10^{-4} \mathrm{~g} / \mathrm{m}^{3}$, which exceeds the Federal air quality standard for particulates.

\section{Residential (Suburban)}

$1 \times 10^{-5} \mathrm{~g} / \mathrm{m}^{3}$ Average particle level in Brookhaven area about $40 \mu \mathrm{g} / \mathrm{m}^{3}=4 \mathrm{x}$ $10^{-5} \mathrm{~g} / \mathrm{m}^{3}$ of which less than $25 \%$ comes from entrainment of soil from site, given essentially all the site will have vegetation cover. Note EPA usually assumes $1 \mathrm{x}$ $10^{-4} \mathrm{~g} / \mathrm{m}^{3}$, which exceeds the Federal air quality standard for particulates.

\section{Open Space (Undeveloped Park Visitor)}

$1 \times 10^{-5} \mathrm{~g} / \mathrm{m}^{3}$ Average particle level in Brookhaven area about $40 \mu \mathrm{g} / \mathrm{m}^{3}=4 \times$ $10^{-5} \mathrm{~g} / \mathrm{m}^{3}$ of which less than $25 \%$ comes from entrainment of soil from site, given essentially all the site will have vegetation cover. Note EPA usually assumes $1 \mathrm{x}$ $10^{-4} \mathrm{~g} / \mathrm{m}^{3}$, which exceeds the Federal air quality standard for particulates.

\section{Recreation (Developed Park Visitor)}

$2 \times 10^{-5} \mathrm{~g} / \mathrm{m}^{3}$ Average particle level about $40 \mu \mathrm{g} / \mathrm{m}^{3}=1 \times 10^{-5} \mathrm{~g} / \mathrm{m}^{3}$ of which less than $25 \%$ comes from entrainment of soil from site, given site will largely be covered by vegetation. During active sport, however, more dirt may be entrained in the air locally. Assume individual is exposed for 0.5 hour out of 4 hour visit to $1 \times 10^{-5} \mathrm{~g} / \mathrm{m}^{3}$ (RESRAD default), remaining 3.5 hours to $1 \times 10^{-5}$ 
$\mathrm{g} / \mathrm{m}^{3}$. Weighted average exposure is $2 \times 10^{-5} \mathrm{~g} / \mathrm{m}^{3}$. Note EPA usually assumes $1 \times 10^{-4} \mathrm{~g} / \mathrm{m}^{3}$, which exceeds the Federal air quality standard for particulates.

\section{Shielding Factor, Inhalation (same as RME)}

Commercial//ndustrial

0.4 ANL 1993b, p. 112. This is the RESRAD default.

Residential (Suburban)

0.4 ANL 1993b, p. 112. This is the RESRAD default.

Open Space (Undeveloped Park Visitor)'

1.0 All inhalation exposure is outdoors.

Recreation (Developed Park Visitor)

1.0 All inhalation exposure is outdoors.

Shielding Factor, External Gamma (same as RME)

Commercial/Industrial

0.8 ANL 1993b, p. 129.

Residential (Suburban)

0.8 ANL 1993b, p. 129.

Open Space (Undeveloped Park Visitor)

1.0 All exposure is outdoors.

Recreation (Developed Park Visitor)

1.0 All exposure is outdoors.

Fraction of Time Spent Indoors (same as RME)

General Approach

This refers to the fraction of time spent indoors on-site. Exposure to direct radiation and contaminated wind-blown dust from outdoors is lower when indoors.

0.214 Assumes workers are on site $250 \mathrm{~d} / \mathrm{y}$ (EPA, 1991). That is, they work the equivalent of 50 weeks/y, $40 \mathrm{~h} / \mathrm{wk}$. It is assumed workers spend 7.5 hours of the work day indoors and 1 hour outdoors on site.

$$
(7.5 \mathrm{hrs} / \mathrm{d} \times 250 \mathrm{~d} / \mathrm{y}) / 8760 \mathrm{hrs} / \mathrm{y}=0.214
$$

Assumes workers spend all their time other than 40 hours per week off the site.

BNL (1995b) assumed the fraction of time indoors was 0.06 . That is the equivalent of 2 hours per day indoors; it basically assumes an outdoor worker. Current BNL employees include a small group that may spend such a small amount of time indoors, but radiation exposure of current BNL employees is controlled through administrative controls of DOE and BNL. These soil cleanup 
criteria are designed to address the safety of future workers at commercial or industrial facilities at the BNL site. Planned commercial development in the area surrounding the BNL site include two shopping centers and a corporate park (BNL, 1995a). If the future of the developed area of the BNL site were to be commercialized, similar uses would be expected. It is unlikely that outdoor industrial operations such as a junk yard would be compatible with these nearby uses. If industrial facilities were to locate on the site, light manufacturing with few outdoor operations, seems more likely. Workers and visitors to this type of commercial or industrial facility are likely to virtually all of their time indoors. Even workers whose job includes lawncare or other outdoor maintenance are unlikely to spend substantial amounts of time outdoors.

\section{Residential (Suburban)}

0.57 Residents spend $350 \mathrm{~d} / \mathrm{y}$ on site. This assumes 15 days are spent elsewhere, e.g., vacation, weekends away, etc. (EPA, 1991). EPA (1994) reported the mean percentage of time spent indoors at home from several sources as $14.2 \mathrm{hrs} / \mathrm{d}$.

$14.2 \mathrm{hr} / \mathrm{d} \times 350 \mathrm{~d} / \mathrm{y} / 8760 \mathrm{hrs} / \mathrm{y}=0.57$

\section{Open Space (Undeveloped Park Visitor)}

$0 \quad$ All time spent outdoors.

Recreation (Developed Park Visitor)

$0 \quad$ All time spent outdoors.

\section{Fraction of Time Spent Outdoors}

\section{General Approach}

This refers to the fraction of time spent outdoors on-site. Exposure to direct radiation and contaminated wind-blown dust is higher outdoors than indoors.

Commercial/Industrial

0.03 Assumes workers spend 7 hours indoors and 1 hour outdoors.

$$
(1 \mathrm{hr} / \mathrm{d} \times 250 \mathrm{~d} / \mathrm{y}) / 8760 \mathrm{~d} / \mathrm{y}=0.029
$$

This is the fraction of time spent outdoors during the 250 working days spent on site. Assumes workers spend all their time other than 40 hours per week off the site. Note Collopy (1995) assumes $75 \%$ of workers time on site is spent outdoors.

Residential (Suburban)

0.03 Residents spend $350 \mathrm{~d} / \mathrm{y}$ on site. This assumes 15 days are spent elsewhere, e.g., vacation, weekends away, etc. (EPA, 1991). EPA (1994) reported the mean percentage of time spent outdoors at home from several sources as $0.72 \mathrm{hrs} / \mathrm{d}$.

$$
0.72 \mathrm{hr} / \mathrm{d} \times 350 \mathrm{~d} / \mathrm{y} / 8760 \mathrm{hrs} / \mathrm{y}=0.029
$$


Open Space (Undeveloped Park Visitor)

0.0014 Assume an average of 4-hours per visit, $3 \mathrm{~d} / \mathrm{y}(4 * 3 / 8760)$.

Recreation (Developed Park Visitor)

0.009 Assume $20 \mathrm{~d} / \mathrm{y}$ for an average of $4 \mathrm{~h} / \mathrm{d}$ or

$(20 * 4 / 8760)=0.009$ fraction of time outdoors on site.

Fruits, Vegetables, Grain Consumption (kg/y) (same as RME)

General Approach

This parameter estimates the total amount of food consumed in this category.

RESRAD then adjusts this factor by the fraction of food that is home grown. The RESRAD default value is $160 \mathrm{~kg} / \mathrm{y}$. Yang and Nelson (1984) estimated daily average food intake by category and subcategory for use in estimating radionuclide intake of individuals in the general population. They estimated total intake of produce (other than leafy vegetables) and grains at $162 \mathrm{~kg} / \mathrm{y}$, similar to the RESRAD default.

Commercial/Industrial

$0 \quad$ No produced grown in industrial or commercial area.

Residential (Suburban)

$160 \mathrm{~kg} / \mathrm{y}$ The RESRAD default.

Open Space (Undeveloped Park Visitor)

$160 \mathrm{~kg} / \mathrm{y}$ The RESRAD default. The reason this category is turned on in the open space scenario arises from the possibility that visitors may collect mushrooms or berries.

Recreation (Developed Park Visitor)

$0 \quad$ Assumed no edible material grown in a recreational area.

\section{Leafy Vegetable Consumption (kg/y) (same as RME)}

\section{General Approach}

This parameter estimates the total consumption of leafy vegetables. RESRAD then adjusts this factor by the fraction of food that is home grown. The RESRAD default value is $14 \mathrm{~kg} / \mathrm{y}$. Yang and Nelson (1984) estimated daily average food intake by category and subcategory for use in estimating radionuclide intake of individuals in the general population. They estimated total intake of produce (other than leafy vegetables) and grains at $14 \mathrm{~kg} / \mathrm{y}$, similar to the RESRAD default.

Commercial/Industrial

$0 \quad$ No edible material assumed to be grown in commercial or industrial areas. 
Residential (Suburban)

$14 \mathrm{~kg} / \mathrm{y}$ RESRAD default. Same value used in ANL (1993a,b).

Open Space (Undeveloped Park Visitor)

$0 \quad$ No leafy vegetable consumption.

Recreation (Developed Park Visitor)

$0 \quad$ No edible material assumed to be grown in recreational area.

\section{Contaminated Fraction of Plant Food}

Commercial/Industrial

$0 \quad$ No produce grown in industrial or commercial area.

Residential (Suburban)

0.1 The bulk of food consumption from plants is from the category "fruits, vegetables, and grains" (160 kg/y out of a total of $174 \mathrm{~kg} / \mathrm{y})$. Yang and Nelson (1984) estimated daily average food intake by category and subcategory for use in estimating radionuclide intake of individuals in the general population.

Grains, however, make up $45 \%$ of the category "fruits, vegetables, and grains" and it is assumed in this suburban residential scenario that no grains are home grown. That reduces the total annual consumption from the RESRAD default of $160 \mathrm{~kg} / \mathrm{y}$ to $89 \mathrm{~kg} / \mathrm{y}$. Citrus fruits also fall into this category. None are home grown in the BNL area. EPA (1990) estimated $50 \mathrm{~kg} / \mathrm{y}$ of citrus fruits in this category. This was from a survey covering only 3 days, however. The overall estimate for the category "Protected Produce" in EPA (1990) in which citrus fruits fell, however, was inconsistent with ( 8.7 times higher than) values from Yang and Nelson (1984) (also an EPA document). Applying the percentage fraction of citrus fruit to the Yang and Nelson number yields $16 \mathrm{~kg} / \mathrm{y}$ for citrus fruit. This leaves only $73 \mathrm{~kg} / \mathrm{y}$ in the fruit, produce and grain category that could possibly be grown in home gardens. Applying the EPA default residential number of $40 \%$ for vegetables and $30 \%$ for fruits as home grown to the vegetables that could be home grown on Long Island, i.e., $14.3 \mathrm{~kg} / \mathrm{y}$ leafy vegetables, $31.4 \mathrm{~kg} / \mathrm{y}$ exposed produce (of which $69 \%$ is fruit and $31 \%$ vegetables) and $39 \mathrm{~kg} / \mathrm{y}$ protected produce, yields $25 \mathrm{~kg} / \mathrm{y}$ vegetables and 6.5 $\mathrm{kg} / \mathrm{y}$ fruit, or $20 \%$ of the $160 \mathrm{~kg} / \mathrm{y}$ total intake. Assume that on average vegetable consumption from home gardens is one-half of the RME. That yields a value of $10 \%$.

\section{Open Space (Undeveloped Park Visitor)}

0.0003 The RME value assumed some visitors may collect mushrooms or berries. Since neither are plentiful in the area, assume RME individual collects 1 $\mathrm{kg} / \mathrm{y}$ out of total fruit, vegetable and grain category of $160 \mathrm{~kg} / \mathrm{y}$, or a fraction of 0.006 . This factor also applies to leafy vegetables. For the average value, we assume that only $5 \%$ of visitors collect mushrooms, berries, etc. $0.05 * 0.006=$ 0.0003 . 
Recreation (Developed Park Visitor)

$0 \quad$ Assumed no edible material grown in recreational area.

\section{Meat Consumption (kg/y)}

\section{General Approach}

It is assumed that because of the suburban nature of the area, no livestock will be kept on site. Therefore, no meat will be produced. In the open space scenario, however, hunting may be allowed (or poachers may hunt illegally). In this scenario, an exposure pathway through eating wild game is included.

\section{Commercial/Industrial}

$0 \quad$ No meat production or hunting in commercial or industrial areas.

\section{Residential (Suburban)}

$0 \quad$ No meat production or hunting in residential areas.

Open Space (Undeveloped Park Visitor)

$51.1 \mathrm{~kg} / \mathrm{y}$ Total of beef, pork and other meat from all sources (Yang and Nelson, 1984).

\section{Recreation (Developed Park Visitor)}

$0 \quad$ No hunting in recreational area.

\section{Contaminated Fraction of Meat Consumption}

Commercial/Industrial

0 No meat production or hunting in commercial or industrial areas.

\section{Residential (Suburban)}

$0 \quad$ No meat production or hunting in residential areas.

\section{Open Space (Undeveloped Park Visitor)}

0.02 It is assumed that the average consumption of deer meat among people who eat deer meet is $5.1 \mathrm{~kg} / \mathrm{y}$, the average of a range from 1.35 to $8.85 \mathrm{~kg} / \mathrm{y}$ (Davis, 1995). Since deer meat is the only contaminated meat consumed and, all deer meat consumed is assumed to come from the site, the fraction of deer meat to total meat for the average person eating deer meat is $10 \%$. We assume that only $20 \%$ of the population eat deer meat, so the contaminated fraction is $0.1 \cdot 0.2=0.02$.

\section{Recreation (Developed Park Visitor)}

$0 \quad$ No hunting in recreational area. 


\section{Soil Ingestion Rate ( $g / \mathbf{y})$}

\section{Commercial/Industrial}

$2.4 \mathrm{~g} / \mathrm{y}$ Based on $10 \mathrm{mg} / \mathrm{d}$. Average value for outdoor industrial workers 15 $\mathrm{mg} / \mathrm{d}$ and for indoor industrial workers $5 \mathrm{mg} / \mathrm{d}$, from Rocky, 1995 based on inferences drawn from Finley and Paustenbach, 1994. Weighting these by 1 hour $/ \mathrm{d}$ outdoors and $7 \mathrm{~h} / \mathrm{d}$ indoors yields $6.5 \mathrm{mg} / \mathrm{d}$. Multiplying this by 365 days yields $2.4 \mathrm{~g} / \mathrm{y}$. RESRAD applies the fraction of time on site to this number.

\section{Residential (Suburban)}

$22 \mathrm{~g} / \mathrm{y}$ Estimated average values are $100 \mathrm{mg} / \mathrm{d}$ for children and $50 \mathrm{mg} / \mathrm{d}$ for adults (EPA, 1993). Assuming a 30 year residence beginning at birth, the annual average exposure is calculated as 6 years at $100 \mathrm{mg} / \mathrm{d}$ and 24 years at $50 \mathrm{mg} / \mathrm{d}$ for $365 \mathrm{~d} / \mathrm{y}$.

$$
[(0.1 \mathrm{~g} / \mathrm{d} \times 6 \mathrm{y})+(0.05 \mathrm{~g} / \mathrm{d} \times 24 \mathrm{y})] \times 365 \mathrm{~d} / \mathrm{y} / 30 \mathrm{y}=21.9 \mathrm{~g} / \mathrm{y}
$$

RESRAD applies the fraction of time on site to this number.

\section{Open Space (Undeveloped Park Visitor)}

$18 \mathrm{~g} / \mathrm{y}$ EPA default adult soil ingestion is $50 \mathrm{mg} / \mathrm{d}$ (EPA, 1993).

$$
0.05 \mathrm{~g} / \mathrm{d} \times 365 \mathrm{~d} / \mathrm{y}=18.3 \mathrm{~g} / \mathrm{y} \text {. }
$$

RESRAD applies the fraction of time on site to this number.

\section{Recreation (Developed Park Visitor)}

$27 \mathrm{~g} / \mathrm{y}$ EPA default central tendency adult soil ingestion is $50 \mathrm{mg} / \mathrm{d}$ (EPA, 1993). That value is then increased by $50 \%$ to account for the greater possibility of contact with soil in sport.

$$
0.05 \mathrm{~g} / \mathrm{d} \times 365 \mathrm{~d} / \mathrm{y} \times 1.5=27.4 \mathrm{~g} / \mathrm{y} \text {. }
$$

RESRAD applies the fraction of time on site to this number.

\section{Mass Loading for Foliar Deposition $\left(\mathrm{g} / \mathrm{m}^{3}\right)$ (same as RME)}

\section{Commercial/Industrial}

$1 \times 10^{-5} \mathrm{~g} / \mathrm{m}^{3} \quad$ Average particle level in Brookhaven area about $40 \mu \mathrm{g} / \mathrm{m}^{3}=4 \mathrm{x}$ $10^{-5} \mathrm{~g} / \mathrm{m}^{3}$ of which less than $25 \%$ comes from entrainment of soil from site, given essentially all the site will have vegetation cover. While an industrial area might generate a higher particulate level, it would not be from contaminated soil. Note EPA usually assumes $1 \times 10^{-4} \mathrm{~g} / \mathrm{m}^{3}$, which exceeds the Federal air quality standard for particulates. Since no vegetation is produced for human consumption on commercial or industrial areas on site, this value has no significance.

\section{Residential (Suburban)}

$1 \times 10^{-5} \mathrm{~g} / \mathrm{m}^{3} \quad$ Average particle level in Brookhaven area about $40 \mu \mathrm{g} / \mathrm{m}^{3}=4 \mathrm{x}$ $10^{-5} \mathrm{~g} / \mathrm{m}^{3}$ of which less than $25 \%$ comes from entrainment of soil from site, given 
essentially all the site will have vegetation cover. Note EPA usually assumes $1 \mathrm{x}$ $10^{-4} \mathrm{~g} / \mathrm{m}^{3}$, which exceeds the Federal air quality standard for particulates.

\section{Open Space (Undeveloped Park Visitor)}

$1 \times 10^{-5} \mathrm{~g} / \mathrm{m}^{3} \quad$ Average particle level about $40 \mu \mathrm{g} / \mathrm{m}^{3}=1 \times 10^{-5} \mathrm{~g} / \mathrm{m}^{3}$ of which less than $25 \%$ comes from entrainment of soil from site, given essentially all the site will have vegetation cover.

\section{Recreation (Developed Park Visitor)}

$1 \times 10^{-5} \mathrm{~g} / \mathrm{m}^{3} \quad$ Average particle level about $40 \mu \mathrm{g} / \mathrm{m}^{3}=1 \times 10^{-5} \mathrm{~g} / \mathrm{m}^{3}$ of which less than $25 \%$ comes from entrainment of soil from site, given essentially all the site will have vegetation cover. This could be slightly higher to be consistent with estimate of soil inhalation, but has no effect since no vegetation is consumed from the site.

\section{Livestock Fodder (applied to deer) (kg/d)}

$6.8 \mathrm{~kg} / \mathrm{d}$ The RESRAD default value for cattle is $68 \mathrm{~kg} / \mathrm{d}$. In this case, there are no cattle; this part of RESRAD is used to estimate the intake of deer. The fraction of the site for which soil is contaminated with radionuclides is $2 \%$ (derived from the BNL Geographic Information System, GIS). From observation, it is clear that deer graze more than proportionally on grassy contaminated areas, but not $100 \%$ of the time. Ten percent is assumed. The intake rate of 68 $\mathrm{kg} / \mathrm{d}$ was thus reduced to $10 \%$ of that value to represent the intake of contaminated plant food by deer. Further improvements can be made to the estimate of dose through this pathway. For example, deer eat different plants than cattle, so the soil to plant uptake factors could be modified.

\section{Livestock (deer) Intake of Soil (kg/d)}

$0.05 \mathrm{~kg} / \mathrm{d}$ The RESRAD default value for cattle is $0.5 \mathrm{~kg} / \mathrm{d}$. In this case, there are no cattle; this part of RESRAD is used to estimate the intake of deer. The fraction of the site for which soil is contaminated with radionuclides is $2 \%$ (derived from GIS). From observation, it is clear that deer graze more than proportionally on grassy contaminated areas, but not $100 \%$ of the time. Ten percent is assumed. The intake rate of $0.5 \mathrm{~kg} / \mathrm{d}$ was thus reduced to $10 \%$ of that value to represent the intake of contaminated plant food by deer. Further improvements can be made to the estimate of dose through this pathway. For example, deer eat considerably less soil than cattle.

\section{Precipitation (same as RME)}

$1.23 \mathrm{~m} / \mathrm{y} \quad$ Based on on-site measurements at BNL 1949-95 (Nagle, 1975, 1978; Cassella, 1996).

\section{Average Wind Speed (same as RME)}

$6.23 \mathrm{~m} / \mathrm{s} \quad$ Based on on-site measurements at BNL 1949-95 (Nagle, 1975, 1978; Cassella, 1996). 


\section{References}

ANL, 1993a, Manual for Implementing Residential Radioactive Material Guidelines Using RESRAD, Version 6.0 (ANL/EAD/LD-2), C. Yu et al., Argonne National Laboratory, Argonne, IL.

ANL, 1993b, Data Collection Handbook to Support Modeling the Impacts of Radioactive Material in Soil (ANL/EIAS-8), Argonne National Laboratory, Argonne, IL.

BNL, 1995, Brookhaven National Laboratory Draft Remedial Investigation/Risk Assessment Report, Operable Unit IIV, Vol. 2B, Baseline Radiological risk Assessment, September 21, Prepared by CDM Federal Programs Corp. New York, New York.

Cassella, V. 1996, personal communication with B. Dionne.

Collopy, P, 1995, Brookhaven National Laboratory Draft Remedial Investigation/Risk Assessment Report Operable Unit INI, Vol. 2B, Baseline Radiological Risk Assessment, CDM Federal Programs Corp., New York.

Davis, M.S. 1995, Memo to H. Knoch, NYSDEC, May 15.

DeRosa M.I, and Levin, R. 1978, Simulation of Man's Respiratory and Metabolic Functions by the Automated Breathing Metabolic Simulator (IC 8766), U.S.

Department of Interior, Bureau of Mines, Washington, D.C.

EPA. 1990, Exposure Factors Handbook (EPAV60/8/043), Exposure Assessment Group, Office of Health and Environmental Assessment, USEPA, Washington, D.C.

EPA1991a, Standard Default Exposure Factors, EPA OSWER Directive 9285.603, March 25, 1991.

EPA, 1991b, Risk Assessment Guidance for Superfund - Volume I Human Health Evaluation Manual (Part B Development of Risk-Based Preliminary Remediation Guidelines) Interim Final,. United States Environmental Protection Agency. (285.7-01B). October 1991.

EPA, 1993, Superfund's Standard Default Exposure Factors for the Central Tendency and Reasonable Maximum Exposure, Review Draft, 4 Nov. (from Rocky Flats, 1995)

EPA, 1994, EPA Radiation Site Cleanup Regulations Technical Support Document: Vol. l; Methods for the development of radionuclide soil cleanup levels (preliminary review draft), prepared by S. Cohen \& Associates for U.S. Environmental Protection Agency, Office of Radiation and Indoor Air, Washington, D.C. March.

EPA, 1995a, Radiation Site Cleanup Regulation 40 CFR 196 (preliminary staff working draft) published in 58 FR 54474, U.S. Environmental Protection Agency, Washington, D.C. 
EPA, 1995b, Air Quality Criteria for Particulate Matter (Review Draft) Vol. 1 (EPA/600/AP/001a, April 1995), Office of Research and Development, U.S. Environmental Protection Agency, Washington, D.C.

Ershow, A.G. and Cantor, K.P, 1989, Total Water and Tapwater Intake in the United States: Population-Based Estimates of Quantities and Sources. Report prepared under National Cancer Institute Order \#263-MD-810264.

Finley, B. and D. Paustenbach, 1994, "The Benefits of Probabilistic Exposure Assessment: Three Case Studies Involving Contaminated Air, Water and Soil. Risk Analysis 14(1) 53-73.

Kleinman, M.T. et al. 1980. "Identifying and Estimating the Relative Importance of Sources of Airborne Particulates", Environmental Science and Technology 14: $62-65$.

Nagle, C.M. 1975, Climatology of Brookhaven National Laboratory 1949 through 1973 (BNL 50466), Brookhaven National Laboratory, Upton, NY 11973.

Nagle, C.M. 1978, Climatology of Brookhaven National Laboratory 1974 through 1977 (BNL 50857), Brookhaven National Laboratory, Upton, NY 11973.

Santana, S. et al. 1990. "Particulate Matter Exposures Estimated From an Indoor-Outdoor Source Apportionment Study", in: Indoor Air '90: Proceedings of the 5th International Conference on Indoor Air Quality and Climate, Vol. 2, Characteristics of Indoor Air, Ottawa Canada, pp. 583-588.

Sehmel, G.A. 1984. "Deposition and Resuspension", Chapter 12 in D. R. Anderson (ed), Atmospheric Science and Power Production, Office of Scientific and Technical Information, U.S. Department of Energy, Washington, D.C.

Sheldon, L.S. et al. 1989. An Investigation of Infiltration and Indoor Air Quality: Final Report, New York State Energy Research and Development Authority, Albany, N.Y.

Yang, Y; Nelson, C.B. 1984, An Estimation of the Daily Average Food Intake by Age and Sex for Use in Assessing the Radionuclide Intake of Individuals in the General Population, U.S. Environmental Protection Agency, Office of Radiation Programs, Washington, D.C. 


\section{APPENDIX IV: RADS SOFTWARE FOR CALCULATION OF NET BENEFIT}

The net benefit analysis and qualitative factor analysis methodology is shown in Figure 1. Attachment 1 provides a worksheet to collect the needed input data. A software application has been developed by Brookhaven National Laboratory. The cost-benefit analysis module is more fully described in RADS (Version 1.0) Radiological Assessment and Design System, Users Manual, March 1994. The following is a brief description of the procedure for a net benefit analysis and a qualitative factor analysis.

First, the cost savings associated with the implementation of the remedial alternative, e.g., reduced maintenance labor, operations labor, inspection labor, waste processing, chemicals, consumables, and radioactive waste; and increased salvage, can be estimated using the RADS- APM (ALARA Protective Measure) Benefit Calculation Worksheet (Attachment 3). An example of cost savings resulting from the remediation of the radioactive source in soil is that monitoring of wells may not have to be performed after 5 to 10 years. This would be the case if radiochemical analysis results indicate that groundwater levels are low and decreasing.

Next, the cost elements for implementation of the remedial alternative are estimated, e.g., design and engineering, equipment procurement, fabrication, installation or construction labor, operation, maintenance, associated training and procedures, additional chemicals, additional consumables, special tools, additional radioactive waste, and the costs to decontaminate, decommission, dispose of and restore the environment during facility/system closure. The estimated capitol cost for excavation and/or treatment, the annual operation \& maintenance cost, waste processing, storage, transport and disposal costs, and the costs associated with a five year environmental monitoring review that is typically required until 30 years post closure of a Superfund site are also included. These costs can be documented on the RADS - APM Cost Calculation Worksheet (Attachment 4).

Next, the present and future maximum individual and collective doses without remedial action, with the remedial action, to implement the remedial action, and to decommission and restore the environment during facility/system closure are estimated for each alternative/preliminary guidelines combination. The radiation dose to the public should include the present and future maximum and average individual as well as the collective radiation dose. These radiation doses should be estimated using approved computer models. The doses should be estimated assuming no remediation, with remediation and include the dose to the public resulting from the decommissioning and environmental restoration process. RADS- Estimated Radiation Dose to Be Avoided Worksheet (Attachment 5) can be used to document the worker and public radiation dose avoided. The net benefit must take into consideration the monetary value of the dose avoided or the dose expended both to the workers and the public. It can be assumed that the value of the radiation detriment for a unit of radiation dose, 
namely one person-rem, is equivalent to $\$ 300$ to $\$ 10,000$ for a member of the public and for a worker depending on their proximity to the radiation dose limit.

Another important set of considerations in the evaluation of net benefit is the estimation of the potential value of other risks and damages to be avoided as a result of the remedial action e.g., injury and death to workers, environmental damage, public/worker concerns, litigation costs and civil penalties, facility shutdown, etc. The equivalent value of these probabilistic risks and damages can be documented using the RADS-Estimated Value of Avoided Risks and Damages Worksheet (Attachment 6). The following risks and damages might be expected if no remedial action was selected: 1) wetland contamination and prevention of use by wildlife, 2) loss of future sale of several acre lots, and 3) worker and public concern for no remedial action. These risks or damages typically would not be expected if the remedial action is performed.

The summary of the quantitative results from the net-benefit analysis for each remedial alternative and preliminary remedial guideline can be presented as follows:

1) Cost for remedial alternative

2) Benefits from remedial alternative

3) Value of collective dose averted

4) Value of other avoided risks and damages

5) Net Benefit

This information can be concisely documented on the RADS- Net Benefit Evaluation Worksheet (Attachment 7).

The final step in the evaluation process is to review the net benefit of the various remedial alternatives and to consider the other social, economic, political and technological factors before reaching a conclusion on the selected alternative. Qualitative factors to be considered include: worker health and safety, public health and safety, environmental risks, community/worker concerns, regulatory compliance, long-term effectiveness, permanence, reduction of toxicity, mobility or volume via treatment and other considerations. The summary of the results from the qualitative factor analysis for each remedial alternative can be concisely documented on the Qualitative Factor Analysis Worksheet RADS- Net Benefit Evaluation Worksheet (Attachment 8).

Finally, using in part the data and information described above the quantitative and qualitative factors for the various remedial alternatives can be organized by the nine criteria specified by the EPA in the CERCLA Rule. The facts relating to the costs, benefits, risks and other societal and political considerations can than be presented to the decision makers. 
Figure 1. ALARA Protective Measure Analysis - Flow Chart

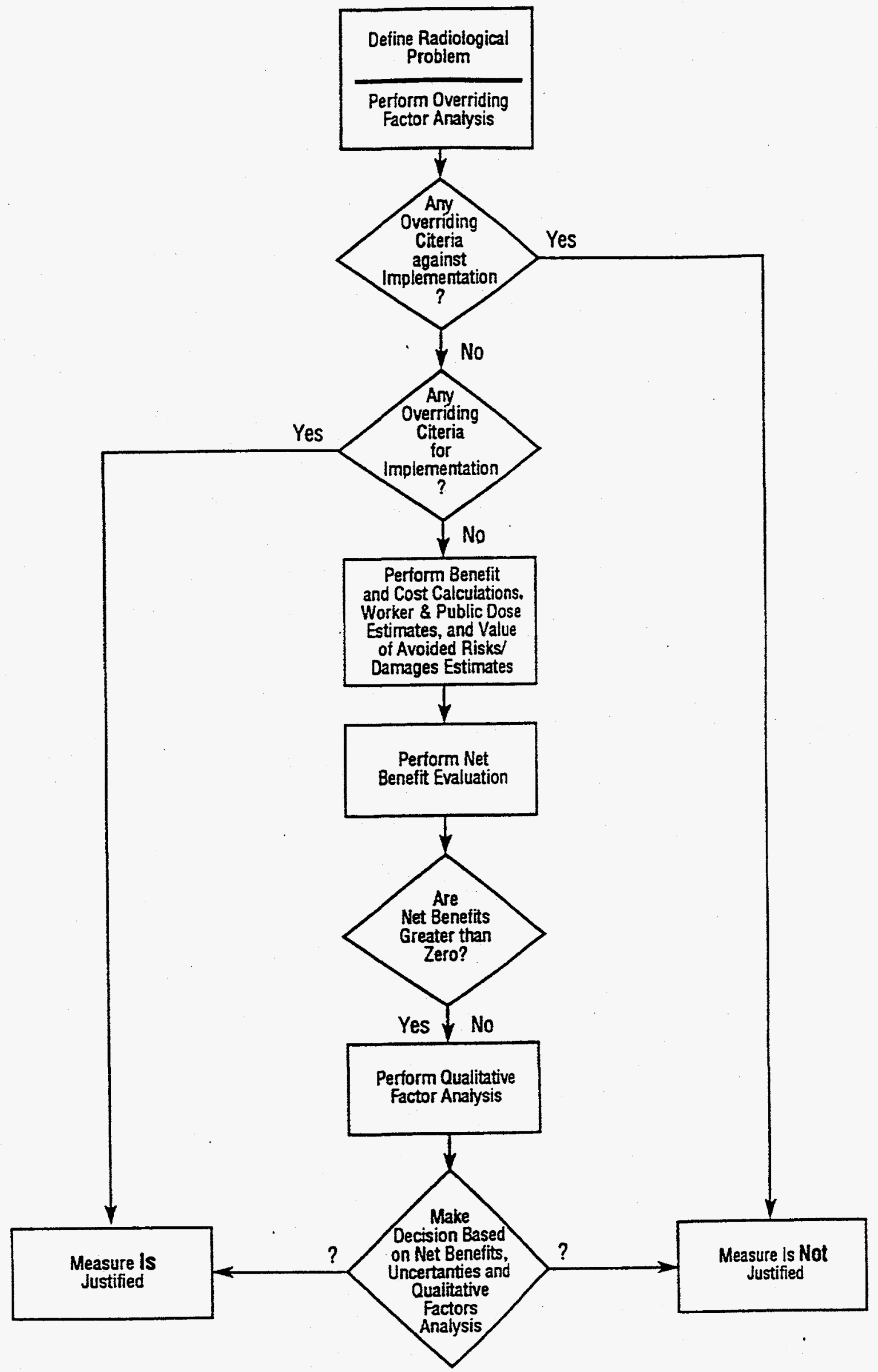




\section{ATTACHMENT 1. RADIOLOGICAL PROBLEM DEFINITION WORKSHEET}

A1. Describe the facility, its present radiological conditions, and the radiological activity of concern.

A2. Describe the proposed ALARA protective measure (APM).

A3. Determine the relevant time frame for estimation of cost elements and exposure impact.

A4. Identify the cost savings associated with the implementation of the APM, e.g., maintenance labor, operation labor, inspection labor, production, processing, salvage, reduced chemicals, reduced consumables, and reduced radwaste.

A5. Identify the cast elements for implementation of the APM, e.g., design and engineering, equipment procurement, fabrication, installation or construction labor, operation, maintenance, associated training and procedure, additional chemicals, additional consumables, special tools, additional radwaste, as well as the costs to decontaminate decommission, dispose of and restore the environment during facility/system closure.

A6. Estimate the collective dose without the protective measure, with the protective measure, to implement the protective measure, and to decommission and restore the environment during facility/system closure. Determine, if possible, the maximum individual dose for the present or existing radiological activity.

A7. Estimate the potential value of the risks and damages to be avoided as a result of the protection measure; e.g., injury and death to workers excluding radiation, environmental damage, publichworker concerns, litigation costs and civil penalties, facility shutdown, etc. Determine, if possible, or estimate the probability of these damages occurring. 
ATTACHMENT 2. OVERRIDING FACTOR ANALYSIS WORKSHEET

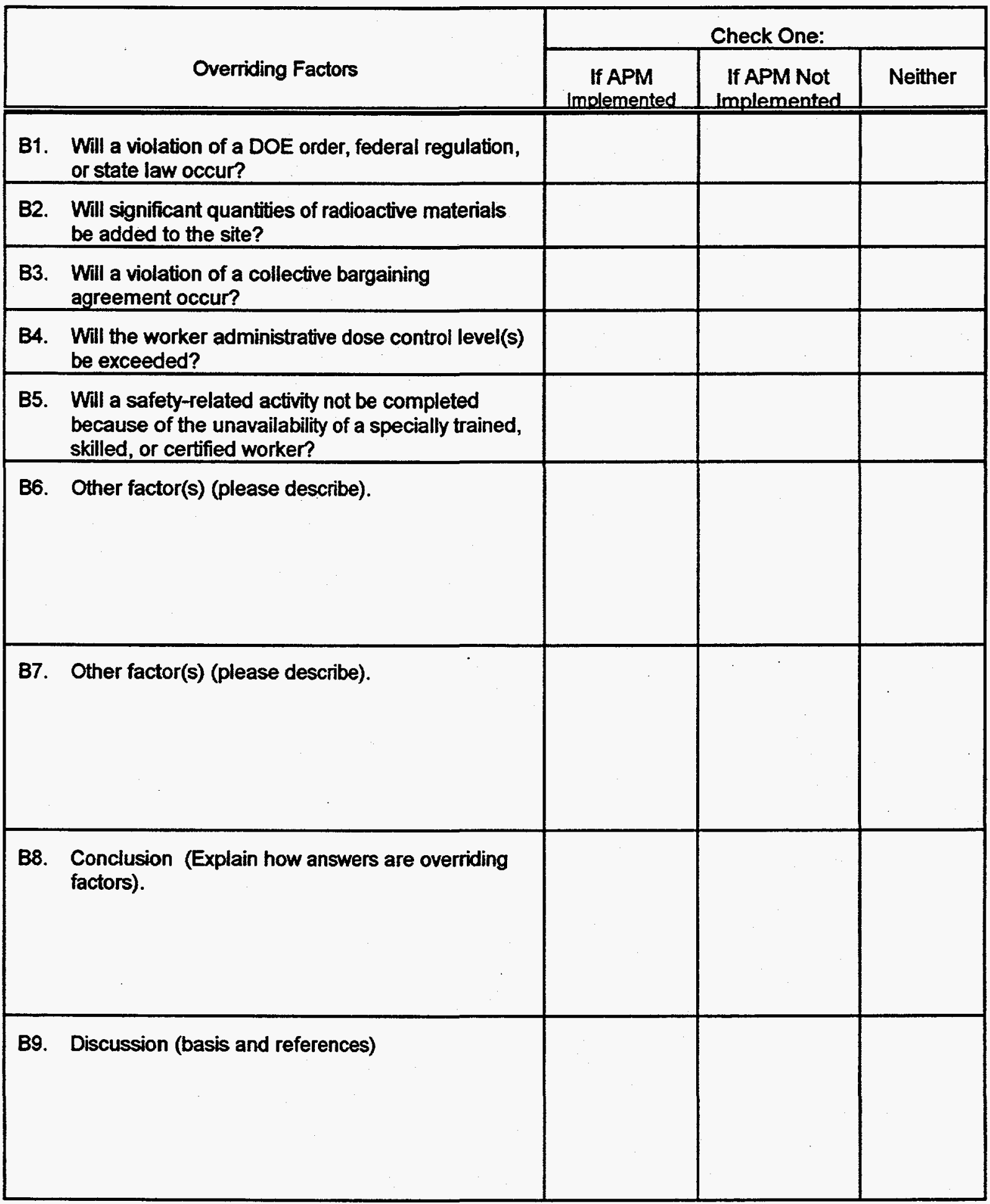




\section{ATTACHMENT 3. APM BENEFIT CALCULATION WORKSHEET}

\begin{tabular}{|c|c|c|c|c|}
\hline Task & Ouantity & Unit Cost & Cost & Item(s) \\
\hline $\begin{array}{l}\text { C1. Maintenance Labor } \\
\text { Enter the total estimated labor savings for the } \\
\text { protective measure. Obtain the estimated total } \\
\text { maintenance hours saved. Obtain the appropriate } \\
\text { dollar/hour rate from the Cost Control Group. Enter } \\
\text { the product(s) on line(s) for items C1. }\end{array}$ & & & & C1 \\
\hline $\begin{array}{l}\text { C2. Operations/Production Labor } \\
\text { Enter the total estimated operation/production labor } \\
\text { savings for the protective measure. Obtain the } \\
\text { estimated total operation hours saved. Obtain the } \\
\text { appropriate dollar/hour rate from the Cost Control } \\
\text { Group. Enter the product(s) on line(s) for items C2. }\end{array}$ & & & & C2 \\
\hline $\begin{array}{l}\text { C3. Inspection/Surveillance Labor } \\
\text { Enter the total estimated inspection/surveillance labor } \\
\text { savings for the protective measure. Obtain the } \\
\text { estimated total inspection hours saved. Obtain the } \\
\text { appropriate dollar/hour rate for inspection from the } \\
\text { Cost Control Group. Enter the product(s) on line(s) } \\
\text { for items C3. }\end{array}$ & & & & C3 \\
\hline $\begin{array}{l}\text { C4. Efficiency and/or Reliability Savings } \\
\text { Enter the total estimated savings associated with } \\
\text { production or processing improvements provided by } \\
\text { the protective measure. Enter the dollar amount of } \\
\text { these savings on line(s) for items C4. }\end{array}$ & & & & C4 \\
\hline $\begin{array}{l}\text { C5. Miscellaneous Savings } \\
\text { Enter estimated savings from miscellaneous items } \\
\text { (e.g., salvage value of old equipment, reduced } \\
\text { chemical and consumable materials, reduced } \\
\text { radwaste). Enter the dollar amount of these savings } \\
\text { on line(s) for items C5. }\end{array}$ & & & & $\mathrm{C5}$ \\
\hline
\end{tabular}

TOTAL ECONOMIC BENEFITS

Enter the total estimated benefits of the protec- tive measure. Add all savings from lines for items $\mathrm{C1}$ through C5, and enter total into Box C.

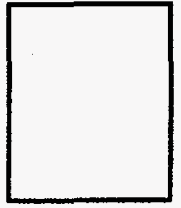

Box C 
ATTACHMENT 4. APM COST CALCULATION WORKSHEET

\begin{tabular}{|c|c|c|c|c|}
\hline Iask & Ouantity & Unit cost & Cost & Item(s) \\
\hline $\begin{array}{l}\text { D1. Design and Engineering } \\
\text { Enter the total estimated design engineering cost for } \\
\text { the protective measure. Obtain the estimated hours } \\
\text { to design and engineer the protective measure. } \\
\text { Obtain the appropriate dollar/hour rate from the Cost } \\
\text { Control Group. Enter the product(s) on line(s) for } \\
\text { item(s) D1. }\end{array}$ & & & & D1 \\
\hline $\begin{array}{l}\text { D2. Capital Equipment, Fabrication, Material } \\
\text { Enter the total estimated capital costs of equipment, } \\
\text { fabrication, and materials for the new technique. } \\
\text { Include "up front" hidden costs such as R\&D, } \\
\text { certification, patent rights, auxiliary construction } \\
\text { facilities, etc. Enter product(s) on line(s) for item(s) } \\
\text { D2. }\end{array}$ & & & & D2 \\
\hline $\begin{array}{l}\text { D3. Installation and Construction } \\
\text { Enter the total estimated labor costs to install the } \\
\text { protective measure including start up, testing, and } \\
\text { operational readiness reviews. Obtain the estimated } \\
\text { total hours of facility and contractor personnel to } \\
\text { install and test. Obtain the appropriate dollarhour } \\
\text { rate for facility and contractor labor. Enter the } \\
\text { product(s) on line(s) for item(s) D3. }\end{array}$ & & & & D3 \\
\hline $\begin{array}{l}\text { D4. Implementation: Procedure. Training } \\
\text { Administrative Costs } \\
\text { Enter the estimated costs for training, procedure } \\
\text { development, and additional administrative and } \\
\text { technical services associated with the protective } \\
\text { measure (additional O\&M being a negative savings } \\
\text { obtained in lines C1,C2, and C3 above from the } \\
\text { difference between the existing and the protective } \\
\text { technique costs for operations, maintenance, and } \\
\text { inspection). Enter the product(s) on line(s) for item(s) } \\
\text { D4. }\end{array}$ & & & & D4 \\
\hline $\begin{array}{l}\text { D5. Operation and Maintenance } \\
\text { Enter the total estimated costs to operate and } \\
\text { maintain the protective measure. Obtain the } \\
\text { estimated hours to maintain and operate. Obtain the } \\
\text { appropriate dollar/hour rate for each work group. } \\
\text { Enter the product(s) on line(s) for item(s) D5. }\end{array}$ & & & & D5 \\
\hline
\end{tabular}




\begin{tabular}{|c|c|c|c|c|}
\hline Task & Ouantity & Unit Cost & Cost & Item(s) \\
\hline $\begin{array}{l}\text { D6. Miscellaneous Costs } \\
\text { Enter the estimated total costs for miscellaneous } \\
\text { items, e.g., chemicals, consumable materials, special } \\
\text { tools, additional radwaste. Enter the product(s) on } \\
\text { line(s) for item(s) D6. }\end{array}$ & & & & D6 \\
\hline $\begin{array}{l}\text { D7. Decontamination, Decommissioning, Disposal } \\
\text { and Environmental Restoration Costs } \\
\text { Enter the total estimated costs associated with the } \\
\text { D\&D, disposal, and environmental restoration of the } \\
\text { protective measure during facility/system closure. } \\
\text { Obtain estimated labor and materials cost to } \\
\text { decontaminate, decommissioning, dispose of, and } \\
\text { restore the environment during closure. Enter the } \\
\text { product(s) on line(s) for item(s) D7. }\end{array}$ & & & & D7 \\
\hline
\end{tabular}

TOTAL ECONOMIC COST

Enter the total estimated costs of the protective measure.

Add all the costs from lines for items D1 through D7 and Grand Total $\square$ enter the total into Box D.

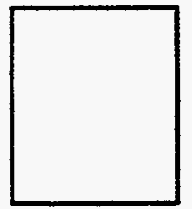

Box D 
ATTACHMENT 5. ESTIMATED RADIATION DOSE TO BE AVOIDED

\begin{tabular}{|c|c|c|c|c|c|c|}
\hline & Description of Radiological Activity & $\begin{array}{l}\text { Number } \\
\text { Exposed }\end{array}$ & $\begin{array}{l}\text { Exp. } \\
\text { Hours }\end{array}$ & $\begin{array}{l}\text { Average } \\
\text { Dose Rate } \\
\text { (mrem/hr) }\end{array}$ & $\begin{array}{l}\text { Collective } \\
\text { Dose } \\
\text { (Person- } \\
\text { Rem) }\end{array}$ & $\operatorname{Item}(\mathbf{s})$ \\
\hline \multirow[t]{2}{*}{ E1. } & \multirow[t]{2}{*}{$\begin{array}{l}\text { Dose to workers from existing or present } \\
\text { radiological activity }\end{array}$} & \multicolumn{5}{|c|}{ 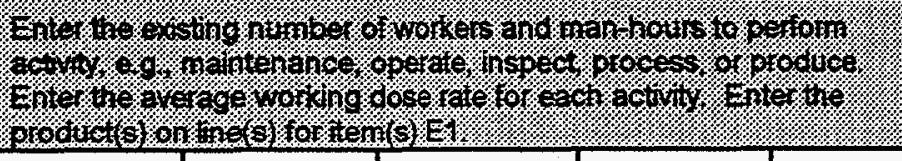 } \\
\hline & & & & & & E1 \\
\hline \multirow[t]{2}{*}{ E2. } & $\begin{array}{l}\text { Dose to workers to perform radiological } \\
\text { activity with APM implemented }\end{array}$ & \multicolumn{5}{|c|}{ 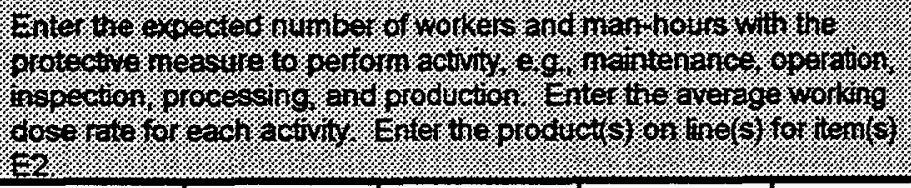 } \\
\hline & & & & & & E2 \\
\hline \multirow[t]{2}{*}{ E3. } & $\begin{array}{l}\text { Dose to workers to install and implement } \\
\text { APM }\end{array}$ & \multicolumn{5}{|c|}{ 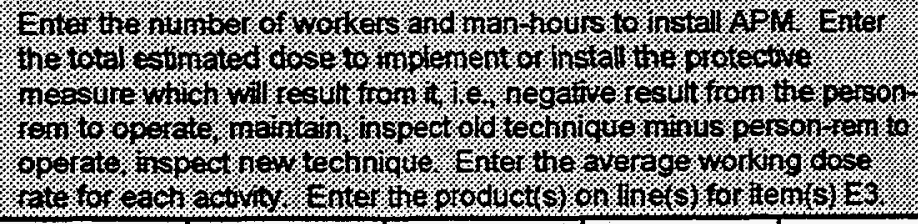 } \\
\hline & & & & & & E3 \\
\hline \multirow[t]{2}{*}{ E4. } & $\begin{array}{l}\text { Dose to workers from } \\
\text { decommissioning'restoration of APM during } \\
\text { closure }\end{array}$ & \multicolumn{5}{|c|}{ 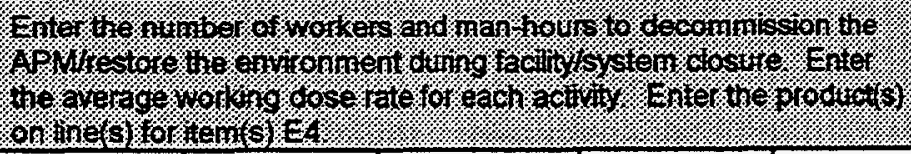 } \\
\hline & & & & & & $E 4$ \\
\hline & & & & & & \\
\hline
\end{tabular}


ATTACHMENT 5. ESTIMATED RADIATION DOSE TO BE AVOIDED (Cont.)

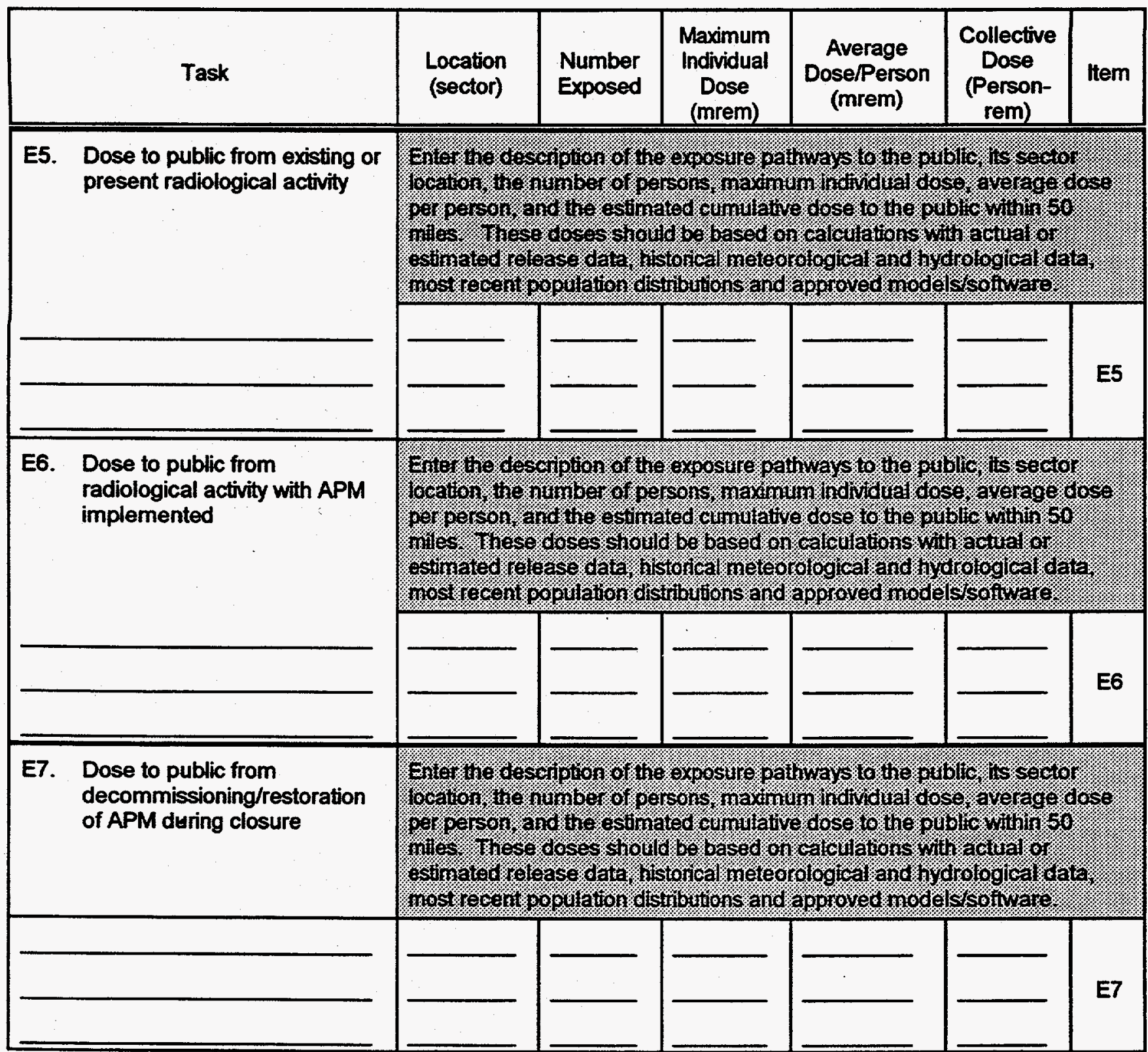

TOTAL WORKER DOSE AVOIDED

$E_{1}-E_{2}+E_{3}+E_{4}=$

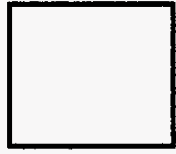

Box $E^{\prime}$

TOTAL PUBLIC DOSE AVOIDED

$E_{5} E_{6}+E_{d}=$

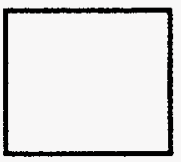

Box E" 
ATTACHMENT 6. ESTIMATED VALUE OF AVOIDED RISKS AND DAMAGES

\begin{tabular}{|c|c|c|c|c|}
\hline Task & Prob. & $\begin{array}{l}\text { Value of } \\
\text { Damages }\end{array}$ & Product & Item(s) \\
\hline $\begin{array}{l}\text { F1. Estimated Value of Potential Injury or Deaths to Workers Avoided } \\
\text { Enter the probability of an injury or death occurring. Enter the estimated } \\
\text { value of potential injury or deaths to workers avoided from other risks (i.e., } \\
\text { toxic chemicals, industrial hazards, fire, etc.). Enter the product(s) on } \\
\text { line(s) for item F1. }\end{array}$ & & & & $F 1$ \\
\hline $\begin{array}{l}\text { F2. Estimated Value of Potential Damages to the Environment to be } \\
\text { Avoided } \\
\text { Enter the probability of damages occurring to the environment. Enter } \\
\text { estimated value of potential damages to the environment to be avoided (i.e., } \\
\text { endangeres species, national monument, wetand contamination, land } \\
\text { contamination, odors, etc.). Enter the product(s) on line(s) for item F2. }\end{array}$ & & & & F2 \\
\hline $\begin{array}{l}\text { F3. Estimated Value of Potential Public Worker Concerns to be Avoided. } \\
\text { Enter the probability of public or worker concerns occurring. Enter the } \\
\text { estimated value of potential publichorker concerns (i.e., press releases, } \\
\text { news releases, public hearings, union negotiations, employee moral, etc.) } \\
\text { and associated corrective actions to be avoided. Enter the product(s) on } \\
\text { line(s) for item } F 3 \text {. }\end{array}$ & & & & F3 \\
\hline $\begin{array}{l}\text { F4. Estimated Value of Impacts Associated with Noncompliance to be } \\
\text { Avoided } \\
\text { Enter the probability of a violation or civil penalty being levied. Enter the } \\
\text { estimated value of impacts associated with noncompliance with federal, } \\
\text { state, or local laws sand rules (i.e., fines, civil penalties, legal expenses, cost } \\
\text { of corrective actions, regulatory curtailment of programs, etc.) to be } \\
\text { avoided. Enter the product(s) on line(s) for item F4. }\end{array}$ & & & & F4 \\
\hline $\begin{array}{l}\text { F5. Estimated Damages Associated with Shutdown to be Avoided } \\
\text { Enter the probability of a facility shutdown or severe impact to the facility } \\
\text { mission occurring. Enter the estimated value for the damages associated } \\
\text { with shutdown of a facility program or its operation and its impact on long } \\
\text { term facility mission objectives that could be avoided. Enter the product(s) } \\
\text { on line(s) for item F5. }\end{array}$ & & & & F5 \\
\hline F6. Other Risks/Damages to be Avoided & & & & F6 \\
\hline
\end{tabular}




\section{ATTACHMENT 7. NET BENEFIT EVALUATION WORKSHEET}

\begin{tabular}{|l|l|l|}
\hline \multicolumn{1}{|c|}{ Cost/Benefit } & Dollars & Item(s) \\
\hline \hline G1. Estimated Economic Benefits & & \\
Enter the results from Box C on line for item G1. & & \\
\hline G2. Estimated Economic Costs & & G2 \\
Enter the results from Box D on line for item G2. & & \\
\hline $\begin{array}{l}\text { G3 Net Economic Benefit (Costs) } \\
\text { Estimated benefit on line for item G1 minus estimated cost on line for item G2. } \\
\text { Enter (G1) - (G2) on line G3. }\end{array}$ & & \\
\hline
\end{tabular}

\begin{tabular}{|c|c|c|c|c|}
\hline Value of Net Dose Savings & $\begin{array}{c}\text { Person- } \\
\text { Rem }\end{array}$ & $\begin{array}{l}\text { Dollars/ } \\
\text { Person- } \\
\text { Rem } \\
\end{array}$ & Dollars & Item(s) \\
\hline $\begin{array}{l}\text { G4. Value of Worker Net Dose Avoided } \\
\text { Enter the result from Box } E^{\prime} \text { and multiply by } 2,000 \\
\$ / \text { person-rem. Enter result on line for item } G 4 \text {. }\end{array}$ & & $x \$ 2,000=$ & & G4 \\
\hline $\begin{array}{l}\text { G5. Value of Public Net Dose Avoided } \\
\text { Enter the result from Box } E^{\prime \prime} \text { and multiply by } 2,000 \\
\text { S/person-rem. Enter result on line for item } G 5 \text {. }\end{array}$ & & $x \$ 2,000=$ & & G5 \\
\hline
\end{tabular}

\begin{tabular}{|l|c|c|}
\hline Value of Avoid Risks and Damages & Dollars & ltem(s) \\
\hline \hline G6. Estimated Value of Avoided Risks and Damages & & G6 \\
\hline
\end{tabular}

\section{Net Benefit}

Net benefit on line $G 3$ plus the dollar value of the net dose savings on line for item $G 4+G 5$ plus avoided risks and damages $G 6$, i.e., $(\mathrm{G} 3)+\ldots(\mathrm{G} 6)$.

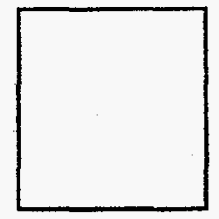

Box $G$

\section{Net Benefit Decision Index}

1. If the net benefit is greater than 0 but marginal, proceed to Worksheef $H$ and perform the Qualitative Factor Analysis; then decide whether or not to accept the protective measure.

2. If the net benefit is less than or equal to 0 , proceed to Worksheet $H$ and perform the Qualitative Factor Analysis, and either reject the protective measure or reevaluate the \$/person-rem values using a casespecific value for the radiation detriment instead of the value used above. 


\section{ATTACHMENT 8. QUALITATIVE FACTOR ANALYSIS WORKSHEET}

\section{Ouestions on Oualitative Factors}

\section{H1. Worker Health and Safety Risks}

\section{Group Weighting Factor:}

H1.1. How well will the implementation of the APM be in either preventing or reducing the radiation exposure to workers over the expected lifetime of the facility/protective measure?

H1.2. How well will the implementation of the APM be in either preventing or reducing the potential impacts on workers during its installation or during its decommissioning/remediation?

H1.3.

H1.4.

H1.5.

H2. Public Health and Safety Risks

Group Weighting Factor:

H2.1. How well will the implementation of the APM be in either preventing or reducing the current level of public exposure to other risks over the expected lifetime of the facility/protective measure?

H2.2. How well will the implementation of the APM be in either preventing or reducing the potential impact on public health from other risks during its installation or during its decommissioning/remediation?

H2.3.

H2.4.

H2.5.

H3. Environmental Risks

Group Weighting Factor:

H3.1 How well will the implementation of the APM be in either preventing or reducing a potential adverse impact on the natural environment over the expected lifetime of the facility/protective measure?

H3.2

H3.3

H3.4 
H3.5

H4. CommunityMorker Concerns

Group Weighting Factor:

H4.1. How large a segment of the public or worker population will be aware or concerned about the problem addressed by the APM?

H4.2. How much acceptance or interest will the community or worker population be expressing for the implementation of the APM?

H4.3

H4.4

H4.5

H5. Regulatory Compliance

Group Weighting Factor:

H5.1. To what degree will the implementation of the APM prevent a violation of a requirement from the DOE orders, federal regulations, or state/local laws?

H5.2. How likely is it that the problem to be addressed by the APM, or the implementation of the APM, will be resulting in an allegation from local, state, or regulatory authorities that its personnel are legally liable and subject to civil or criminal penalties?

H5.3

H5.4

H5.5

H6. Long Term Effectiveness and Permanence Group Weighting Factor:

H6.1. How effective and permanent will the implementation of the APM be in providing protection against the radiation hazard and/or the spread of radioactive materials during the expected life of the facility/protective measure?

H6.2 How effective and permanent will the implementation of the APM be in producing a minimal residual risk from the radiation hazard and/or the spread of radioactive materials following the conclusion of the expected activities?

H6.3 


\section{Questions on Oualitative Factors.}

H6.4

$H 6.5$

H7. Reduction of Toxicity, Mobility, or Volume through Treatment

Group Weighting Factor:

H7.1. How well will the implementation of the APM be in reducing the amount of radioactive materials that will be decontaminated, treated, reused, or recycled?

H7.2.

H7.3

H7.4

H7.5.

H8. Miscellaneous Concerns

Group Weighting Factor:

H8.1. How well will the implementation of the APM be in increasing the flexibility of personnel or other resources?

H8.2. How well will the implementation of the APM be in improving or maintaining the current level of quality and operability of the facility?

H8.3.

H8.4.

H8.5. 